\title{
Australian hermit crabs of the genera Paguristes Dana, Stratiotes Thomson, and Pseudopaguristes McLaughlin (Crustacea: Anomura: Paguroidea: Diogenidae)
}

\author{
Patsy A. McLaughlin \\ Shannon Point Marine Center, Western Washington University, 1900 Shannon Point Road, \\ Anacortes WA 98221-9081B, U.S.A. \\ email: hermitufidalgo.net
}

\begin{abstract}
An examination of the specimens thought to represent the hermit crab genus Paguristes sensu lato in all of the major Australian Museums has provided material for the first comprehensive review of this taxon in Australian waters. In keeping with the current subdivision of Paguristes, the recently resurrected Stratiotes Thomson is represented by the former Paguristes tuberculatus Whitelegge. The two recently described species, Paguristes monoporus Morgan and Paguristes laurentae Morgan and Forest have been reassigned to Pseudopaguristes, the latter as the senior synonym of Paguristes brachytes Komai and Pseudopaguristes gracilis Rahayu. The regional fauna of Paguristes sensu stricto now includes 20 species, of which four are new to science. Paguristes crinitimanus sp. nov and $P$. triton sp. nov. are described from the Northern Territory, $P$. geminatus sp. nov. from Queensland, and $P$. dampierensis sp. nov. from the Dampier Archipelago of Western Australia. Five species, $P$. alcocki McLaughlin and Rahayu, $P$. palythophilus Ortmann, $P$. simplex Rahayu and McLaughlin, $P$. miyakei Forest and McLaughlin, and $P$. puniceus Henderson, are new additions to the Australian fauna. Range extensions also have been recorded for six species, including two previously known only from the type localities. Full descriptions and illustrations are provided for the new taxa, while more abbreviated descriptions and figures accompany the remainder. Keys to the genera, and keys to the Australian species of Pseudopaguristes and Paguristes s.s. also are provided.
\end{abstract}

\section{INTRODUCTION}

The Woodside Dampier Expeditions of 1998 and 1999, conducted by the staff of the Western Australian Museum in the Dampier Archipelago, Western Australia, resulted in the accumulation of a very diverse collection of Crustacea. During a study of the hermit crabs from those expeditions, several problems regarding species assigned to Paguristes Dana, 1851, came to the author's attention, prompting a review of all the Australian species attributed to the genus. No comprehensive overview of regional species assigned to Paguristes had ever been published, although Morgan (1987d) provided a key to the species known at the time. In that publication, Morgan commented that Paguristes barbatus (Heller, 1862) and Paguristes setosus (H. Milne Edwards, 1848) might be expected to occur in Australia. However, Forest and McLaughlin (2000) demonstrated convincingly that H. Milne Edwards' (1848) citation of New Guinea as the type locality of $P$. setosus was an unfortunate lapsus calami. The former authors restricted the distributions of both $P$. barbatus and $P$. setosus to New Zealand.

As noted by Komai (2001), species of Paguristes are typically characterized by the presence of paired and modified first and second pleopods in males, paired and modified first pleopods in females, and 13 pairs of gills. The paired first and second male pleopods have been considered so characteristic of the genus, that rarely have investigators even counted the gills. When McLaughlin (2002a) discovered a species that, while possessing male and female paired pleomeral appendages typical of Paguristes, differed in several other attributes, she did count the gills. McLaughlin's aberrant species had only eight functional pairs of gills. The arthrobranchs of the third maxillipeds and chelipeds were rudimentary or vestigial, and the pleurobranch on either wall of the fifth thoracic somite (above the second pereopod) was missing entirely. Although pleurobranch loss is well documented in several genera of the Paguridae, and arthrobranch loss on the maxillipeds of three other genera, only in Propagurus McLaughlin and de Saint Laurent, 1998, has a similar loss of both arthrobranchs and pleurobranchs been reported. For her new and deviate diogenid species, McLaughlin (2002a) proposed the new genus Pseudopaguristes and recommended that 
investigators verify gill numbers of all the presumed Paguristes species they encountered.

Rahayu (2005) did just that and found, in the species represented in the collections of the Muséum national d'Histoire naturelle, Paris, that while most had the expected 13 pairs of gills, others had just 12 pairs and some had only eight. As a result, Rahayu proposed a second genus for those species in which gill loss was restricted just to the pleurobranch on each side of the fifth thoracic somite. Among the species checked by Rahayu and found with this latter reduced gill number was Paguristes setosus, the senior subjective synonym of Stratiotes setosus Thomson, 1899. As pointed out by Rahayu (2005), although Thomson's (1899) diagnosis of Stratiotes Thomson, 1899, made no mention of gill number, the name of his monotypic genus, based on $S$. setosus, was available for the genus she was proposing to accommodate those species that were found to have only 12 pairs of gills.

In his catalogue of Australian decapods, Davie (2002) listed 14 species of Paguristes sensu lato (s.I)., the majority of which were known from limited areas around the country and thought to be endemic. While several species of Paguristes sensu stricto (s.s.) are still known only from restricted areas, the review of specimens from all of the major Australian Museums has appreciably expanded the ranges of some species and added others to the faunal inventory. Several species, heretofore known only from the Indian Ocean, Japanese, Philippine and/or Indonesian waters, have been identified from Australia for the first time. Additionally, four new species of Paguristes s.s. have been recognized. Stratiotes tuberculatus (Whitelegge, 1900) is still the only regional representative of that genus and its Australian distribution is limited to Queensland, New South Wales and Western Australia; however, it also has been found in Indonesia (Rahayu, 2005), thus negating its endemicity. Pseudopaguristes is represented in by $P$. monoporus (Morgan, 1987c) and $P$. laurentae (Morgan and Forest, 1991a), but it is now recognized that neither species is restricted in its distribution to Australian waters.

\section{MATERIALS AND METHODS}

The terminology for the diagnoses and descriptions generally follows that of McLaughlin (2002a), but Lemaitre (2004) for gill structure and Schram and Koenemann (2004) for pleonal somites and appendages. The shield length (indicated in millimeters in parentheses following the number of specimens of each sex) is measured from the tip of the rostrum or midpoint of the rostral lobe to the posterior margin of the shield, and provides an indication of animal size. The ratio of carapace length to antennal flagellar length has been determined by measuring the entire carapace from the tip of the rostrum or midpoint of the rostral lobe to the midpoint of the posterior margin of the carapace, and the maximum length of either flagellum excluding the peduncle. The ratio of corneal diameter to length of the ocular peduncle has been obtained by measuring the length of the left ultimate peduncular segment, including the cornea, along the lateral surface; corneal diameter is the maximum dorsally measured width of the left cornea. Measurements of dactylar and propodal lengths of the second and third pereopods have been taken along the dorsolateral surface of each segment, exclusive of the claw. Segmental width represents the maximum width of the lateral surface. In taxa where there is appreciable counterclockwise rotation of the articulations of the chelas and/or carpi that has placed the morphological dorsal surfaces in lateral positions, the dorsomesial margin is referred to as the upper margin and the dorsal surface as the outer face; the lower margin is equivalent to the dorsolateral margin.

The terminology used by McLaughlin (2002a) and herein differs from that of Morgan (1987a, c, d) and Morgan and Forest (1991a) in the ratio involving the lengths of the dactyls of the chelipeds. The latter authors compared dactylar length to the overall length of the propodus (palm plus fixed finger). In the present descriptions and diagnoses, dactylar length is compared to the length of the palm alone, measured on the dorsomesial (upper) margin of each segment.

Similarly, the terminology used in the descriptions of the male first pleopods is that of McLaughlin and Provenzano (1974) rather than that of Komai (2001) for the following reason. The male first pleopods in Paguristes species each consist of two segments, the basal segment being rather short and subtriangular, while the distal segment is foliaceous and rolled in such a manner as to form a deep groove open toward the sagittal plane (Forest, 1954). As pointed out by Forest, when the pleopods are viewed in situ on the ventral surface of the animal (Figure 1a), the distal segment of each appears to consist of two plates, the inferior lamella, visible in its entirety in the uppermost plane, and the superior lamella, in contact with the thorax and for the most part hidden from view by the inferior lamella. The superior lamella is cut into two lobes, the external and internal lobes (Figure 1b, c). Although the free margin of the inferior lamella may appear mesial in position because of the rolled attitude of this segment (Figure 1a), it is still the lateral or outer margin (Figure 1c) of the segment. Komai (2001, fig. 1) illustrated the male first pleopod from a "dorsal aspect" and a "mesial aspect". McLaughlin and Provenzano (1974) used "external view" and "internal view", but both terminologies are misleading. McLaughlin and 
Provenzano's (1974, fig. 2b) and (Komai's (2001: fig. 1, left) figs each show the external surface of the appendage from its inner side (i.e., the outer or external surface of the superior lamella) as does Figure $1 \mathrm{~b}$ of the present study. McLaughlin and Provenzano's (1974, fig. 2c), Komai's (2001 fig. 1 right) and Figure 1c of the current study all show the inner surface of the external lobe of the superior lamella and the rolled outers surfaces of the internal lobe of the superior lamella and inferior lamella. In the latter study, the outer side of the external surface of the inferior lamella is shown in Figure 1a.

Komai (2001: 359) stated that he had "found that the 'lateral margin' of the inferior lamella used by them [McLaughlin and Provenzano (1974)] actually represents the mesial margin." In Komai's (2001, fig. 1, left illustration) the mesial margin of the internal lobe of the distal segment is correctly labeled, as is the distolateral margin of the inferior lamella. In contrast, in the "mesial" view (loc. cit., right illustration), that same inferior lamellar margin is labeled the mesial margin, as is the margin of the internal lobe. A segment can have only one mesial margin, and that margin is the free edge of the internal lobe as correctly illustrated by McLaughlin and Provenzano (1974, fig. 2a, b) and by Komai (2001, fig. 1, left). As previously indicated, on the in situ pleopod the lateral or free external margin of the inferior lamella is outermost, whereas the mesial or internal margin of the inner lobe is innermost. Because of the orientation of the pleopod and its rolled disposition, the external margin of the inferior lamella faces the midline of the body, thus it is mesial in position; however, this rolled attitude also places the inner margin of the internal lobe similarly directed toward the midline of the body. Torsion does not change the morphology of a segment, only its orientation.

Diagnoses are provided for the three genera; abbreviated descriptions and pertinent illustrations are included for the previously known species. Taxa that are new to science or new to the Australian fauna are described in detail and fully illustrated. Keys to the genera of Paguristes s.l. and Australian species of Paguristes s s. and Pseudopaguristes are presented. Genera and species are arranged according to their placement in the keys; however, those arrangements are not intended to necessarily convey phylogenetic relationships.

Materials for this review have come from the Australian Museum, Sydney (AM); Muséum national d'Histoire naturelle, Paris (MNHN); Museum Victoria, Melbourne (NMV), Museum of the Northern Territory, Darwin (NTM); National Museum of the Philippines, Manila (NMP); Natural History Museum and Institute, Chiba (CBM-ZC); Queensland Museum, Brisbane (QM), South Australian Museum, Adelaide (SAMA), University of Tel Aviv, Tel Aviv (UTA), The Natural History Museum, London (NHM), and the
Western Australian Museum, Perth (WAM). The abbreviations FMNH, MZB, MZS, and NSMT refer to the University of Florida's Museum of Natural History, Gainesville, Florida, U.S.A; Museum Zoologi Bogor, Lembaga IImu pengetahuan Indonesia, Cibinong, Indonesia; Musée Zoologique Strasbourg, France; and National Science Museum, Showa Memorial Institute, Tasukuba City, Japan, respectively.

The abbreviations stn, ovig., juv., coll., Arch., C., I., Is, Pen., $\mathrm{Pt}$ and $\mathrm{n}$. $\mathrm{mls}$ are used for station, ovigerous, juvenile, collector(s) Archipelago, Cape, Island, Islands, Peninsula, Point and nautical miles, respectively.

\section{SYSTEMATICS}

Key to the genera of Paguristes $s .1$.

1. Thirteen pairs of bi- or quadriserial gills [pair of arthrobranchs on arthrodial membranes of third maxillipeds, chelipeds and pereopods 2-4; single pleurobranch on wall on each side of thoracomeres 5-7 (cephalothoracic somites XI, XII, and XIII of Pilgrim, 1973)] (Figure 1d) Paguristes Dana s.S

Fewer than thirteen pairs of bi- or quadriserial gills

2. Twelve pairs of bi- or quadriserial gills [pair of arthrobranchs on arthrodial membranes of third maxillipeds, chelipeds and pereopods $2-4$; single pleurobranch on wall on each side of thoracomeres 6 and 7 (cephalothoracic somites XII and XIII)] (Figure 1e)....

Stratiotes Thomson

Eight pairs of functional bi- or quadriserial gills Ipair of well developed arthrobranchs on arthrodial membranes of pereopods 2-4 (arthrobranchs of third maxillipeds and chelipeds reduced or absent); single pleurobranch on wall on each side of thoracomeres 6 and 7 (cephalothoracic somites XII and XIII)] (Figure 1f) Pseudopaguristes McLaughlin

\section{Paguristes Dana, 1851 s. s.}

Paguristes Dana, 1851: 269. - Dana, 1952a: 122. Dana, 1852b: 437. - A. Milne-Edwards and Bouvier, 1893: 32. - Alcock, 1905: 30 (in part). Forest, 1954: 170 (in part). - Forest and de Saint Laurent, 1968: 67 (in part). - Zariquiey Alvarez, 1968: 235. - McLaughlin, 1974: 17. - Miyake, 1978: 25. - Forest and McLaughlin, 2000: 58 (in part). - Rahayu, 2006: 350 .

Pagurites Lörenthey and Beurlen, 1929: 71 (misspelling). 


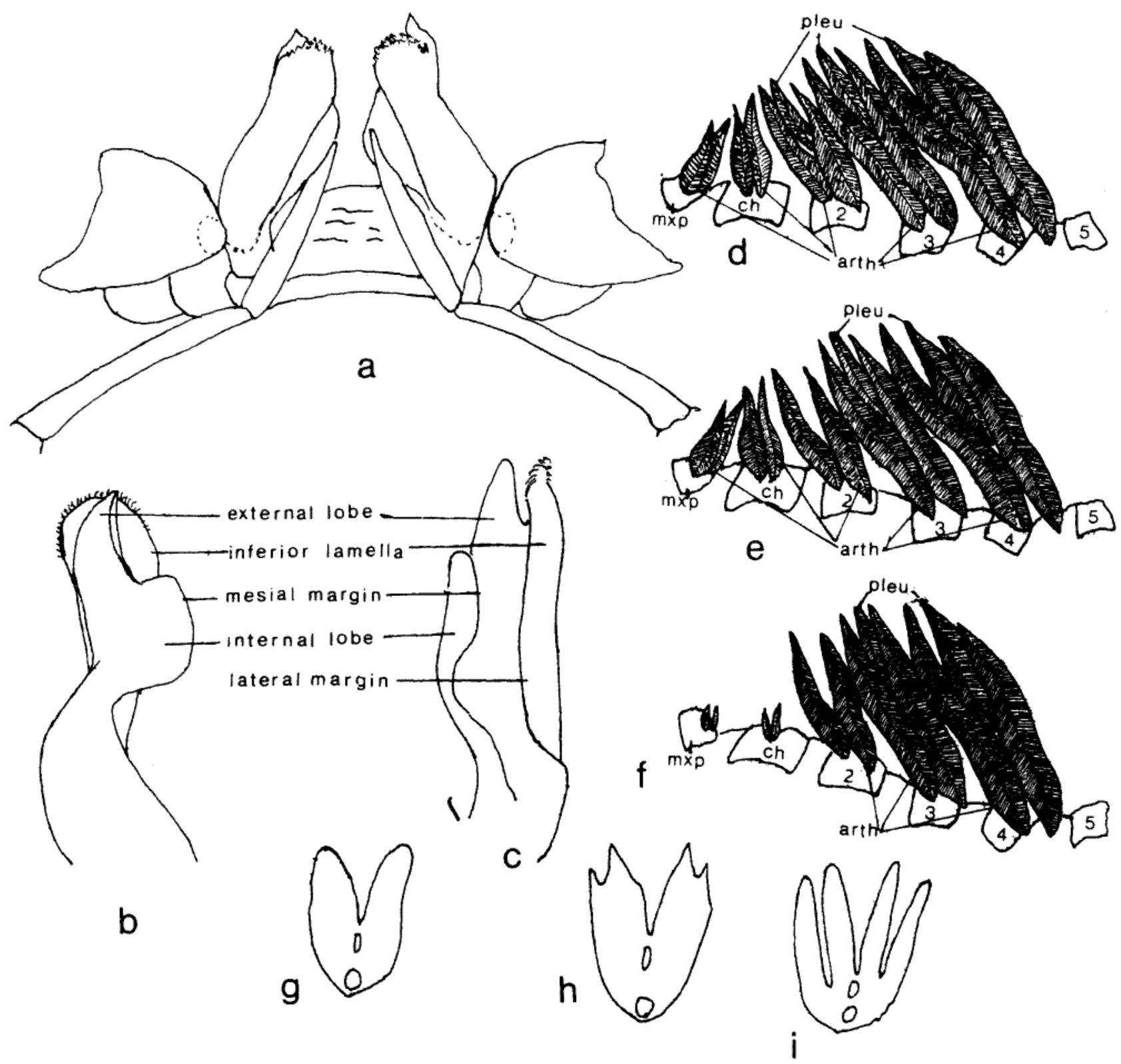

Figure 1 Morphology, a-c, male first pleopods; d-f, gills; g-i, gill lamellae. a, coxae and sternite of male fifth pereopods and anterior abdominal somites; $\mathbf{b}$, male first pleopod modified as gonopod (outer surface, setae omitted); c, male first pleopod modified as gonopod (inner surface, setae omitted); $\mathbf{d}$, thirteen phyllobranchiate gills; e, 12 phyllobranchiate gills; $\mathbf{f}$, eight functional phyllobranchiate gills; $\mathbf{g}$, biserial lamella; $\mathbf{h}$, distally quadriserial lamella; i, deeply quadriserial lamella. [a after Forest et al. (2000); b, c after McLaughlin and Provenzano (1974); d, f-i after McLaughlin (2003)]. Not to scale.

\section{Type species}

By subsequent designation by Stimpson (1858), Paguristes hirtus Dana, 1851, shown by Haig (1956) to be a junior subjective synonym of Paguristes weddellii $(\mathrm{H}$. Milne Edwards, 1848); gender masculine.

\section{Diagnosis}

Thirteen pairs of gills [no pleurobranch on eighth (last) thoracic somite], usually biserial (Figure 1g), but occasionally deeply (Figure 1i) or at least distally quadriserial (Figure $1 \mathrm{~h}$ ). Rostrum variable, usually produced beyond level of lateral projections, occasionally reduced or obsolete. Ocular acicles well developed, usually well separated, sometimes approximate, at least distally. Antennal acicles well developed, usually spinose or spinulose. Antennal flagellar length medium to short. Endopods of maxillules with external lobes well developed, recurved. Third maxillipeds approximate basally or nearly so; no accessory tooth on crista dentata of ischium. Chelipeds usually similar in form and most frequently equal or subequal, occasionally unequal and/or dissimilar; claws generally corneous, fingers usually opening in horizontal plane, occasionally opening obliquely. 
Dactyls of fourth pereopods terminal; preungual process sometimes present; propodal rasp variable.

Males with paired gonopores; no sexual tubes, but with pair of pleopods modified as gonopods on first and second pleomeres; unpaired, biramous left pleopods on pleomeres 3-5, exopod well developed, endopod rudimentary or vestigial.

Females usually with paired gonopores, occasionally only single gonopore on coxa of left third pereopod, with or rarely without pair of uniramous pleopods on first pleomere; following 3 pleomeres with unpaired biramous left pleopods, both rami well developed; left pleopod of pleomere 5 as in males. Often pleomeral fold developed posterior to base of fourth pleopod to form brood pouch.

\section{Remarks}

As demonstrated by McLaughlin (2004b), species of this genus exhibit considerable intraspecific variability in many of the morphological characters heretofore used for specific identifications. Some of these variations appear growth related while others do not. For example, ocular peduncle length very often increases with increased animal size, whereas corneal diameter appears to decrease in certain species. In the study of a population of $P$. puniceus Henderson, 1896, McLaughlin (2004b) found that the length by which the antennular peduncles overreached the distal margins of the corneas was considerably greater in females than in males, whereas the antennal flagellar length was consistently shorter in females; however, the disproportionate number of females in the sample precluded a firm conclusion of sexual dimorphism. Neither variations in prominence, acuteness, and even corneous-tipping of spines, nor ratios of segmental lengths of chelipeds and ambulatory legs appeared to be influenced by either size or sex. McLaughlin concluded that rarely would any single character be adequate to define a species of Paguristes. However, one character, the armature of the posterior lobes of the telson (with or without spines on the terminal margins) was recommended by McLaughlin and Provenzano (1975) as a means of separating Paguristes into two groups and has been used in subsequent studies as a differentiating character (e.g., Miyake, 1978; Komai, 2001; McLaughlin and Rahayu, 2005; Rahayu, 2006; Rahayu and McLaughlin, 2006). This character has proved of value in grouping Australian species as well; however, the unarmed posterior lobes have two distinct forms in regional species. These lobes are either roundly subquadrate (figs $2 \mathrm{~h}, 3 \mathrm{e}$ ) or subor roundly triangular (Figure 4f). Komai (2001) found a second character, the armament of the mesial faces of the dactyls of the chelipeds, useful in separating certain generally similar taxa. Although somewhat variable among the Australian species, this character has proved of significant import in distinguishing particular taxa.

\section{Key to the Australian species of Paguristes s.s}

1. Telson with terminal margins of posterior lobes unarmed.

Telson with terminal margins armed with spines or spinules ..................................... 10

2. Chelipeds unequal and dissimilar, outer or dorsal surface of left chela armed with small to tiny or minute tubercles or granules; posterior lobes of telson roundly subquadrate

3

Chelipeds equal, subequal or unequal, similar or dissimilar, outer or dorsal surface of left cheliped variably armed; posterior lobes of telson sub- or roundly triangular

4

3. Mesial face of dactyl of right cheliped with scattered tubercles of varying size and tufts of setae, or at least with irregular surface and setal pits (small individuals); ventral surfaces of dactyls of second and third pereopods each with row of 11-33 small to very small corneous spines [ocular peduncles deep red or salmon-brown with orange at bases of corneas; antennule salmon-brown; chelas and carpi of chelipeds cream and salmonbrown; ambulatory legs salmon-brown with scattered red or red-brown spots]

P. frontalis

Mesial face of dactyl of right cheliped with covering of densely-packed, relatively uniformly-sized very small tubercles and sparsely scattered setae; ventral surfaces of dactyls of second and third pereopods each with row of 43-56 very small to minute corneous spines [ocular peduncles orange or red; antennular peduncles lilac or purple; chelas cream or white, carpi and meri red/ orange with white spines and tubercles; ambulatory legs cream or orange with numerous red or deep pink short longitudinal flecks] ......P. Purpurantennatus

4. Armament of outer or dorsal face of left chela consisting of rounded or flattened scale-like tubercles [in preservative, meri of both chelipeds each with patch of colour on mesial and lateral face]. P. alcocki

Armament of outer or dorsal face of left chela consisting of blunt, subacute, acute and/or corneous-tipped spines

\section{5}

5. Cheliped markedly unequal ......................... 6

Chelipeds equal or subequal ....................... 7

6. Ocular acicles broadened distally, with 1-3 spines; armature of chelas dissimilar; dactyls 
of second and third pereopods only slightly longer than propodi, ventral margins of second pereopods each with 10-15 corneous spines [meri of both chelipeds mottled orange and white] P. kimberleyensis

Ocular acicles narrowed distally, with 1 spine; armature of chelas similar; dactyls of second and third pereopods considerably longer than propodi; ventral margins of second pereopods each with 24-25 corneous spines [subdistal meral patch of colour on mesial face of each cheliped].

$P$. crinitimanus $\mathrm{sp}$. nov.

7. Mesial faces of dactyls of chelipeds each with dense covering of very small spinules or tubercles; brood pouch of female very poorly developed, not covering rami of pleopod 4 and almost completely concealed by dense tufts of long plumose setae

P. triton sp. nov.

Mesial faces of dactyls of chelipeds each with 1 to several regular or irregular rows of small to moderately large spines or tubercles; brood pouch of female moderately to well developed, at least covering rami of pleopod 4 and not concealed by dense tufts of long setae 8

8. Mesial face of dactyl of left cheliped with 1 median or dorsal row of moderately large subacute spines or tubercles, frequently also ventral row of tubercles or protuberances; mesial and/or lateral faces of dactyls of second pereopods each with weak to prominent sulcus, at least proximally .... 9

Mesial face of dactyl of left cheliped with 3-6 irregular rows of small to moderately large spinulose tubercles or spines; mesial and/or lateral faces of dactyls of second pereopods each without longitudinal sulcus proximally [ocular peduncles each with dorsal longitudinal orange stripe; chelipeds and ambulatory legs generally red orange with white spines and tubercles.]

P. palythophilus

9. Branchiostegites each with row of prominent spines on dorsal margin; gills bi- or distally quadriserial; propodal rasp of fourth pereopod with multiple rows or corneous scales; brood pouch of female moderately well developed, subquadrate [ocular peduncles white; chelipeds and ambulatory legs cream or pale orange with deep maroon longitudinal stripes] ......................... $P$. jalur

Branchiostegites each with short row of very small spinules distally; gills deeply quadriserial; propodal rasp of fourth pereopod with 2 or 3 short rows of corneous scales; brood pouch of female moderately well developed, subtriangular or subovate [ocular peduncles solidly coloured; colours of chelipeds and ambulatory legs not known] .. P. simplex

10. Armament of dorsal surfaces of palms consisting of squamiform tubercles

Armament of dorsal surfaces of palms consisting of acute, blunt or tuberculate spines.....

11. Carpi of chelipeds each with large boss dorsodistally [colour not reported] ...P. pugil

Carpi of chelipeds each without large boss dorsodistally

12. Mesial faces of dactyls of chelas each with 3 distinct rows of corneous spinules; dactyls of second and third pereopods each with row of corneous-tipped or corneous spines extending entire length of dorsal margin [colour unknown] ......... P. geminatus sp. nov.

Mesial faces of dactyls of chelas each with several irregular vertical rows of small tubercles; dactyls of second and third pereopods each with 1 or only few small spines proximally on dorsal margin of second or unarmed on third [body and appendages overall pale brown tinted with green; ocular peduncles green; antennules ringed with alternating brown and white; spines of chelipeds brown] P. squamosus

13. Dorsal surfaces of palms and carpi of chelipeds and dorsal and ventral margins of segments of second and third pereopods with dense tufts of long pinnate setae at least partially obscuring surface armatures 14

Dorsal surfaces of chelas and carpi and dorsal and ventral margins of segments of second and third pereopods with or without long simple or pinnate setae but never dense enough to obscure surface armature

14. Rostrum weakly developed as rounded or subtriangular lobe, usually not overreaching level of lateral projections 15

Rostrum well developed, usually acutely triangular, overreaching lateral projections ..

15. Dorsal surfaces of chelas with armature at least partially concealed by tufts of long setae; mesial faces of dactyls of chelas each with 2 longitudinal rows of spines or spinulose tubercles, few widely-spaced spinules ventrally; terminal margins of telson each with prominent spines [in preservative, ocular peduncles each orange with large white patch at base of cornea $P$. dampierensis sp. nov. 
Dorsal surfaces of chelas with armature not partially concealed by tufts of long setae; mesial faces of dactyls of chelas each with scattering of tubercles or small spines, row of flattened plate-like, often fused, tubercles ventrally; terminal margins of telson each with minute or small spines [in preservative ocular peduncles solid orange]

P. brevirostris

16. Dorsal surfaces of palms of chelas each with covering of long simple setae; mesial faces of dactyls of second and third pereopods each with 1 or 2 rows of setae ventrally, ventral margins each with row of 20-25 corneous spines partially obscured by long setae Ishield pale brown with white or cream spots; ocular peduncles pale brown; antennules red/brown; chelipeds pale brown with white spines and tubercles, some patches of red on carpi and meri; ambulatory legs red or red/brown with white patches] ... $P$. longisetosus

Dorsal surfaces of palms of chelas each with covering of dense, long plumose setae; mesial faces of dactyls of second and third pereopods each with 2-4 irregular rows of small corneous spinules, ventral margins each with row of 9-12 corneous spines [shield cream and mottled brown; ocular peduncles pale brown with white near corneas; antennular peduncles brown-grey; chelipeds pale to medium brown, spines cream or white with black tips; ambulatory legs pale brown and cream.] .......... P. sulcatus

17. Ocular acicles widely separated basally, becoming approximate or nearly so distally; armature of mesial faces of dactyls of chelipeds each consisting of dorsal and ventral row of large rounded tubercles Ishield, ocular and antennal peduncles predominantly black with white spots or patches; chelipeds predominantly black and white; ambulatory legs black and white striped with patches of orange.] ... P. alegrias

Ocular acicles widely separated basally and remaining separated distally; armature of mesial faces of dactyls of chelipeds each consisting of numerous and randomly scattered small spinules or tubercles ......... 18

18. Antennal flagella variable in length and setation but not noticeably stout; mesial faces of dactyls of second and/or third pereopods each with row of small or very small corneous spines ventrally.....

17

Antennal flagella longer than carapace, exceptionally stout; mesial faces of dactyls of second and/or third pereopods each without row of small or very small corneous spines ventrally focular peduncles light reddish brown dorsally, darker ventrally; antemnules and antennae light reddish brown; shield and proximal portions of chelipeds and ambulatory legs reddish brown, lighter distally] ..................................... P. miyakei

19. Carpi of chelipeds each with row of very prominent spines on dorsolateral margin; mesial faces of dactyls with covering of small spines or tubercles and usually row of more prominent short, stout spines dorsally [chelipeds, anterior part of carapace, and ambulatory legs salmon-pink shading to cream.] P. aciculus

Carpi of chelipeds each without row or with row of not particularly prominent spines on dorsolateral margin; mesial faces of dactyls with covering of small spines and tubercles, but lacking row of more prominent short, stout spines dorsally [legs and anterior part of carapace light pink; ocular peduncles somewhat darker pink.] ............. P. puniceus

\section{Paguristes frontalis (H. Milne Edwards, 1836)} Figure 2

Pagurus frontalis H. Milne Edwards, 1836: 238, pl. 13, fig. 3. - H. Milne Edwards, 1848: 64

Eupagurus frontalis. - Haswell, 1882: 154.

Paguristes frontalis. - Alcock, 1905: 155. - Baker, 1905: 252, pl. 32, figs 1-7. - McCulloch, 1913: 345 (key). - Hale, 1927a: 89, fig. 84. - Hale, 1927b: 310. - Anderson, 1938: 351. - Clark and Burnet, 1942: 90. - Gordan, 1956: 322 (literature). Philips et al., 1984: 110. - Morgan, 1987b: 536, figs 1, 2. - Morgan, 1987d: 732, fig. 3B, (key). Mower and Shepherd, 1988: 84. - Morgan, 1989: 397, fig. 1c. - Jones and Morgan, 1994: 119 unnumbered fig. - Jones and Morgan, 2002: 119 unnumbered fig. - Davie, 2002: 55.

\section{Material examined}

\section{Syntypes}

"New Holland", Australia, MNHN (not seen).

\section{Other material examined}

South Australia. SAMA 16518 (4 males, 12.3-22.0 $\mathrm{mm}$; 1 ovig. female, $14.3 \mathrm{~mm}$ ). Whittlobee Pt, intertidal, 07.03.1993; SAMA C 17098 (1 male, 6.5 $\mathrm{mm}$ ), Yorke Pen., Edithburgh, $3-5 \mathrm{~m}$, coll. W. Zeidler and K. Gowlett-Homes, 14.03.1994; SAMA C 17095 (1 ovig. female, $14.4 \mathrm{~mm}$; left ambulatory legs missing), Eyre Pen., Smokey Bay, 1-5 m, coll. W. Zeidler, K. Gowlett-Holmes and B.]. McHenry, 08.03.1993. Western Australia. WAM C 9251 (1 
male, $22.5 \mathrm{~mm}$ ), Middle I., Recherche Arch., 9-11 m, 13.02.1960; WAM C 18120 (8 males, 2.7-25.2 $\mathrm{mm}$; 6 females, $4.1-18.4 \mathrm{~mm}$ ), Two Mile Beach

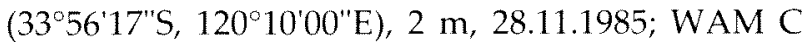
18118, (1 male, $16.3 \mathrm{~mm}$; 1 female, $20.7 \mathrm{~mm}$ ), Little Bay (34 57'S, $\left.118^{\circ} 11^{\prime} \mathrm{E}\right), 18.04 .1986$.

\section{Abbreviated description}

Gills biserial. Shield (Figure 2a) considerably longer than broad, more than half total carapace length; dorsal surface prominently sculptured anteriorly, few spinules or spinulose tubercles laterally. Branchiostegites unarmed. Rostrum triangular, sometimes acute, moderate to elongate, somewhat distally depressed, usually considerably overreaching lateral projections. Lateral projections triangular, each usually with small terminal spine. Ocular peduncles $0.5-0.8$ length of shield; corneal diameter $0.1-0.2$ of peduncular length; ocular acicles distally approximate but separated basally by width of rostrum to 0.5 basal width of 1 acicle, simple, usually with tiny terminal spinule. Antennular peduncles 0.7 length of ocular peduncles to reaching to bases of corneas. Antennal peduncles reaching to or slightly beyond midlength of ocular peduncles; second segment with dorsolateral distal angle terminating in simple or bifid spine, dorsomesial distal angle terminating subacutely or with small spine, sometimes on tuberculate elevation. Antennal acicle reaching to proximal $0.2-0.5$ of ultimate peduncular segment, usually with bifid terminal spine, 2 or 3 spines distolaterally and 1 or 2 mesially in proximal half. Antennal flagella varying from equal to shield length to equal or slightly greater than length of carapace. Posterior carapace median plate moderately broad in juveniles (Figure 2b), becoming increasing narrower and "funnel-shaped" with increased animal size (Figure 2c).

Chelipeds very unequal, left much larger, particularly in large males; pronounced counterclockwise torsion putting dorsal surfaces of chelas and carpi in lateral positions in both sexes; small to moderately large, proximal hiatus between dactyls and fixed fingers. Dactyl, fixed finger and palm of left cheliped densely covered on all surfaces with tiny to minute tubercles in large individuals, larger tubercles in small specimens, slightly larger on convex upper surface; outer surface of palm roundly and evenly convex (Figure 2d). Carpus with outer surface tuberculate, upper margin with larger subacute tubercles or tuberculate spines; inner surface with large, sometimes coalesced tubercles. Merus with row of very small, subacute or blunt tubercles on ventrolateral margin; mesial face with very flattened tubercles ventrodistally, ventromesial margin tuberculate. Right cheliped noticeably shorter; no hiatus between dactyl and fixed finger. Dactyl with row of tubercles on upper inner margin, upper surface with scattered tubercles and tufts of setae; inner surface (Figure 2e) with scattered tubercles and setae, tubercles largest proximally. Palm with row of 3 or 4 tuberculate spines or spinulose tubercles on upper margin; outer face of palm and fixed finger with covering of tubercles; inner face with low protuberances and tufts of setae. Carpus with row of tuberculate spines on upper margin; outer face with covering of moderately large tubercles; inner face with few tubercles, distal margin spinulose and setose. Merus with lateral face and ventrolateral margin granular; mesial face nearly smooth, ventromesial margin with row of very small spines or tubercles.

Dactyls of second and third pereopods slightly to much longer than propodi, twisted in distal halves in larger specimens; second pereopods with lateral faces convex, third with lateral faces weakly concave distally and with sulcus-like concavity proximally; dorsal surfaces each with 1- 4 irregular rows of small but stout corneous spines, number and prominence increasing with increasing animal size; ventral margins each with row of 11-33 small to tiny corneous spines, largest on second pereopods. Propodi of second pereopods each with row of widely-spaced, subacute or acute, small spines on dorsal surface, third unarmed. Carpi of second pereopods each with 1 prominent subdistal spine on dorsal surface and 1 to several smaller spines proximally; carpi of third usually with only subdistal dorsal spine; lateral faces of carpi of both pereopods with 1 or 2 spines on distal margin. Meri each with row of tufts of very short setae on dorsal margins; ventral margins of second pereopods each with row of very small to tiny spines, third unarmed. Fourth pereopods without preungual process at base of claw; often with subdistal corneous spine on dorsal surface, partially obscured by tuft of setae.

Male first pleopods (Figure $2 f, g$ ) each with tuft of long setae on superior mesial angle of basal segment; inferior lamella with row of moderately dense, short setae on lateral margin proximally shifting to inner face distally, single row of corneous, hook-shaped spines on distal margin; exterior lobe approximately equal in length to inferior lamella, distal margin with few short setae; internal lobe very short, moderately broad, with several rows of long, dense setae marginally and extending onto inner face. Second pleopods each with long, naked basal segment; endopod indistinguishable from appendix masculina, inner and distal margins with several rows of long setae. Female first pleopods 2-segmented, only short, stout basal segment calcified; distal segment flattened, leaf-like with marginal long setae and practically totally concealed by setae arising 


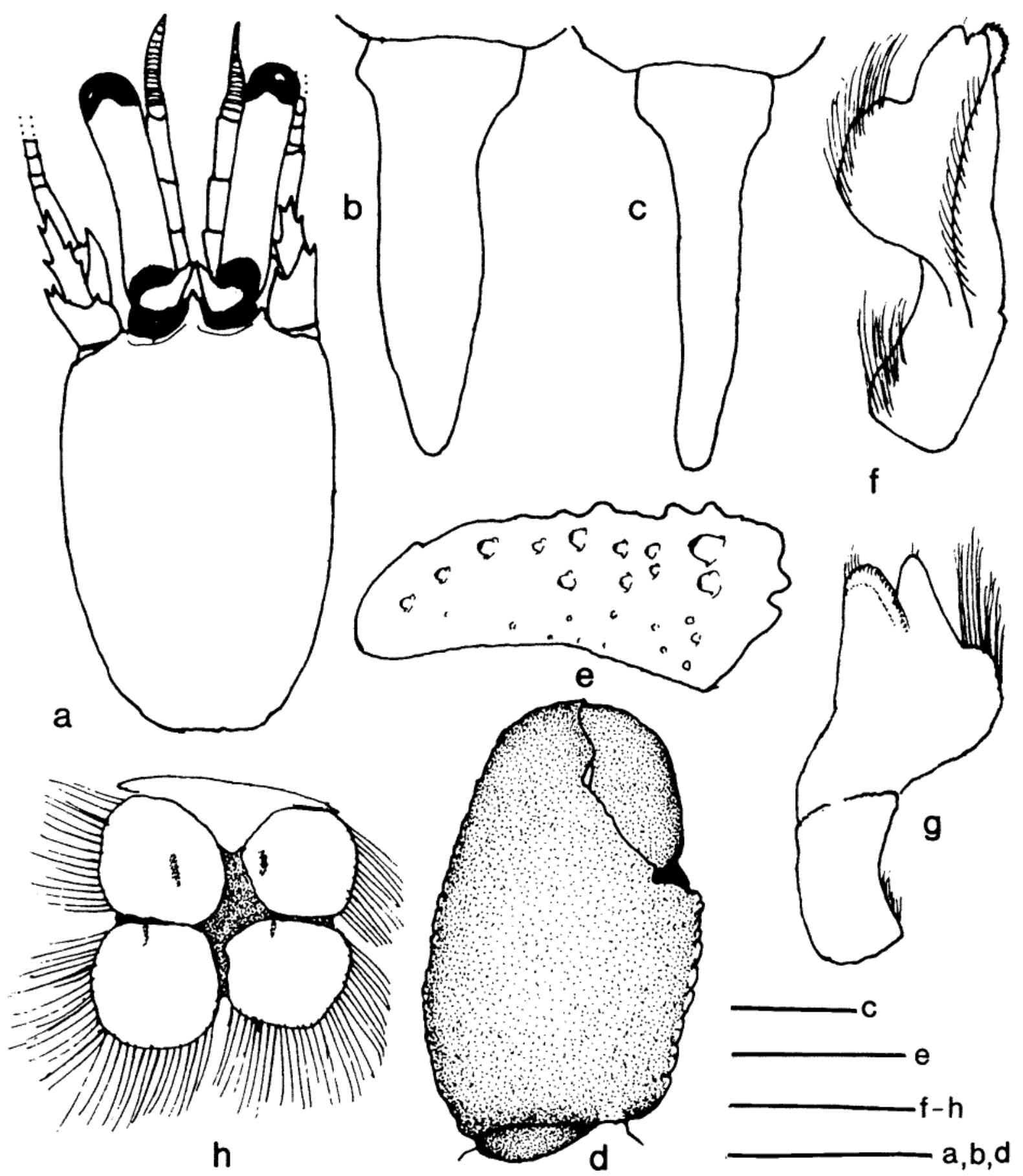

Figure 2 Paguristes frontalis (H. Milne Edwards, 1836), a, d, e, h, male (10.6 mm) (WAM C 18120); b, female (5.0 mm) (WAM C 18120); c, male (16.3 mm) (WAM C 18118); f, g, male (25.2 mm) (WAM C 9251). a, shield and cephalic appendages (aesthetascs and setae omitted); b, c, posterior median plate; d, left chela (dorsolateral view, setae omitted); $\mathbf{e}$, dactyl of right chela (mesial view, setae omitted); $\mathbf{f}, \mathbf{g}$, male first pleopod; $\mathbf{h}$, telson. Scales equal $5 \mathrm{~mm}$ (a, c, d), $3 \mathrm{~mm}$ (f-h), $2 \mathrm{~mm}$ (e) and $1 \mathrm{~mm}(\mathrm{~b})$.

subdistally on basal segment. Brood pouch very large, completely enclosing pleopods $2-4$ and dorsolateral portion of pleon; margin weakly scalloped and provided with row of short setae, at least anteriorly.

Telson (Figure $2 \mathrm{~h}$ ) with deep lateral incisions; posterior lobes roundly subquadrate, left lobe often slightly larger; separated by deep to very deep median cleft; margins of both lobes unarmed but fringed with long setae.

\section{Colour (in life)}

Shield deep salmon-brown. Ocular peduncles deep red-brown or salmon-brown, with bright orange band at base of each cornea; ocular acicles salmon-brown. Antennules and antennae salmon- 
brown. Dactyls of chelipeds cream, sometimes with salmon tinge; palms cream with some salmon proximally; carpi cream and salmon-brown; meri salmon-brown. Second and third pereopods salmon-brown, distal segments usually paler; corneous spines dark, especially on dactyls; scattered red or red-brown at setal pores (after Morgan, 1989).

\section{Habitat}

Shallow subtidal waters associated with rocky reefs and jetty pilings; on sand, rubble and in seagrass.

\section{Distribution}

South and Western Australia.

\section{Variation}

Paguristes frontalis exhibits considerable growth related variation in the length and breadth of the dactyls of the ambulatory legs. The dactyls of small individuals are relatively short, approximately the same length as the propodi, and moderately broad. With increased animal size, the dactyls become much longer than the propodi and appreciably slenderer. There is also some variation in the development of the concavity and sulcus on the lateral face of each third pereopod. Two of the six specimens from South Australia showed almost no development of the sulci. In contrast, the specimens in the three lots from southwestern Australia ranged in size from considerably smaller to considerably larger $(2.7-25.2 \mathrm{~mm})$, but all exhibited at least some indications of sulcuslike depressions. Although all the smaller specimens $(\mathrm{sl}=2.7-5.0 \mathrm{~mm})$ had spine development on the dorsal surfaces of the propodi and carpi of the second pereopods, the number and prominence of corneous spinules on the dorsal surfaces of the dactyls of both the second and third pereopods was correlated to animal size. The number and eminence of the spines increased appreciably in the larger specimens, whereas the size of the tubercles on the palms of the chelipeds decreased from moderately large tubercles in small specimens to tiny or minute tubercles in large individuals.

As indicated in the abbreviated description, the ocular peduncles varied from slightly less than 0.5 to nearly 0.8 of the shield length. Although the ratio of peduncular to shield length did not appear to be function of animal size, the corneal diameter clearly decreased with increased peduncular length. Similarly, animal size did not appear to influence ratios of antennular and antennal peduncular lengths to ocular peduncular lengths, whereas antennal flagellar length was seen to increase with increased size.

\section{Gonopore, gonopod, and pleopod development}

The smallest specimens $(2.7,4.4 \mathrm{~mm})$ were judged to be males because both showed indications of small gonopores on the coxae of the fifth pereopods. There was no development of either first or second pleopods. The pleonal tissues of the smaller specimen were damaged, and the only pleopod apparent was the uniramous fifth. Pleopods 3 to 5 were present in the larger juvenile. Of the remaining two small males $(\mathrm{sl}=4.3,5.0 \mathrm{~mm}$ ) moderately large buds of the first pair of pleopods were apparent in the smaller male, and a quite small bud of the second pleopod was present on the left side. In the larger male, better developed first pleopods were present, as were both of the second pleopods. Gonopores were clearly larger in the presumably older of the two specimens. However, in a still larger male $(\mathrm{sl}=6.7 \mathrm{~mm}$ ) only quite small first pleopods were apparent and there were no indications of second pleopod development; the gonopores were also still quite small. Only two small females were available. The smaller ( $\mathrm{sl}=4.2$ $\mathrm{mm}$ ) had incipient gonopores present on the coxae of the third pereopods, but no indications of first pleopod development. Nor was there any evidence of a left second pleopod, although left uniramous pleopods were developed on pleomeres $3-5$. In the slightly larger female $(\mathrm{sl}=4.6 \mathrm{~mm})$, the gonopores were still relatively small, but small first pleopods were apparent on the ventral surface of pleomere 1 . A small, biramous left second pleopod was also present. A similar condition was noted in a somewhat larger female $(\mathrm{sl}=6.1 \mathrm{~mm})$, whereas, in a female with a shield length of $8.7 \mathrm{~mm}$, while the paired first pleopods were moderately well developed, the left second and third pleopods were still quite small and no fourth pleopod or brood pouch was present.

\section{Remarks}

Morgan (1987d) pointed out the similarities between $P$. frontalis and $P$. purpurantennatus Morgan, 1987d, suggesting that the two species might have been confounded in areas where their ranges overlap in Western Australia. Morgan differentiated the two species primarily by differences in living colour and by the armature of the mesial faces of the dactyls of the right cheliped: covered with widely- and irregularly-spaced spines and tubercles in $P$. frontalis but with a dense covering of similarly-sized, small to very small tubercles in $P$. purpurantennatus. This latter distinction is true in moderate to large individuals, but in small specimens of $P$. frontalis, these tubercles are poorly developed. In fact, in the smallest specimen examined, only one tubercle was present on the dorsoproximal surface of the dactyl. However, it was noted that even in small individuals, the surface appeared irregular as a 
result of scattered setal pits. Only one really small specimen of $P$. purpurantennatus was available for comparison and it was missing the right cheliped. From the material at hand, it would appear that the mesial face of the right dactyl of this species is relatively uniform, with a weak median sulcus developing with increased animal size. The shape and rotation of the left chela also will aid in differentiating the two species. The outer surface of the chela of $P$. frontalis is roundly and evenly convex, whereas the surface is angular in $P$. purpurantennatus, giving a generally rectangular appearance to the chela. The carpal/meral articulation is rotated counterclockwise approximately $45^{\circ}$ in $P$. frontalis, but there is little rotation in P. purpurantennatus.

The telsons of $P$. frontalis and $P$. purpurantennatus, although marginally provided only with setae, do not really correspond to the telsons of McLaughlin and Provenzano's (1975) group B. The characteristic telson of McLaughlin and Provenzano's group B has weakly to prominently asymmetrical posterior lobes that are roundly triangular or subtriangular and separated by an usually obsolete or weak median cleft (e.g., Figure $4 \mathrm{f}$ ); the anterior and posterior portions of the telson are indicated by moderately shallow lateral indentations. In contrast, the telsons of $P$. frontalis and $P$. purpurantennatus are divided by deep lateral incisions and a deep but narrow median cleft; the equal or slightly asymmetrical lobes are roundly subquadrate (figs $2 \mathrm{~h}, 3 \mathrm{e}$ ).

\section{Paguristes purpureantennatus Morgan, 1987d} Figure 3

Paguristes purpureantennatus Morgan, 1987d: 729, figs 2, 3A. - Davie, 2002: 55.

\section{Material examined}

\section{Holotype (not seen)}

Western Australia. WAM C 16855 (male, 21.2 $\mathrm{mm})$, Cosy Corner, near Migo I., W of Albany $\left(35^{\circ} 04^{\prime} 12^{\prime \prime} \mathrm{S}, 117^{\circ} 38^{\prime} 44^{\prime \prime} \mathrm{E}\right), 3.0 \mathrm{~m}$, coll. G. Morgan, 01.12.1985.

Western Australia. WAM C 18098 (1 male, 14.9 $\mathrm{mm}$; 1 female, $8.7 \mathrm{~mm}$; 1 ovig. female, $10.8 \mathrm{~mm}$ ), Geraldton ( $\left.28^{\circ} 46^{\prime} \mathrm{S}, 114^{\circ} 37^{\prime} \mathrm{E}\right)$, intertidal, coll. D.S. Jones, 09.1987; WAM C 29563 (1 female, $3.4 \mathrm{~mm}$ ), W of Garden I. (32 $\left.19^{\prime} \mathrm{S}, 115^{\circ} 07^{\prime} \mathrm{E}\right), 148-154 \mathrm{~m}$, 18.03.1972; WAM C 9362 (2 males, 10.5, $10.9 \mathrm{~mm}$ ), Port Denison (Dongara), coll. B.R. Wilson, 24.08.1958; WAM C 18345 (1 ovig. female, 15.7 $\mathrm{mm})$, Frenchman's Bay, $\mathrm{S}$ of Albany $\left(35^{\circ} 02^{\prime} \mathrm{S}\right.$, $117^{\circ} 53$ 'E), coll. D.S. Jones, 20.01.1988.

\section{Abbreviated description}

Gills biserial. Shield (Figure 3a) distinctly longer than broad; dorsal surface prominently sculptured anteriorly, few spinules laterally. Rostrum long, slender, reaching nearly to or slightly beyond midlength of ocular acicles. Lateral projections triangular, each usually with terminal spinule, occasionally subacute and unarmed. Ocular peduncles 0.6-0.9 length of shield; corneal diameter $0.1-0.2$ of peduncular length; ocular acicles moderately slender, simple, distally approximate, separated basally by approximately 0.5 basal width of 1 acicle. Antennular peduncles 0.6 of ocular peduncles to reaching slightly beyond basal corneal margins; segments unarmed. Antennal peduncles reaching to or slightly beyond midlength of ocular peduncles; second segment with dorsolateral distal angle somewhat produced, with often bifid terminal spine, dorsomesial distal angle with small spine. Antennal acicle reaching to proximal 0.3-0.5 of ultimate peduncular segment, with simple terminal spine, usually 2 spines on lateral surface distally and 1 or 2 on mesial surface in proximal half. Antennal flagella shorter than or equal to length of carapace. Posterior carapace plate somewhat funnel-shaped, at least in large specimens.

Chelipeds very unequal, left much larger than right; somewhat dissimilar in armature; small hiatus proximally between dactyl and fixed finger. Left cheliped (Figure 3b) with slight degree of counterclockwise torsion; surfaces of dactyl densely covered with small to tiny tubercles, sometimes nearly obsolete; dorsomesial margin not delimited; mesial face also usually with weak longitudinal sulcus, at least proximally. Palm with rounded ridge of spinulose or blunt tubercles on dorsomesial margin, dorsolateral margin angular but not distinctly delimited; dorsal surfaces of palm and fixed finger with covering of small to very small tubercles, frequently forming short but distinct longitudinal row on dorsolateral face of palm, lateral surface of fixed finger and distal portion of palm weakly to prominently concave, similarly armed with very small tubercles, scattered somewhat larger tubercles proximally on palm. Carpus with row of acute or subacute spines on dorsomesial margin, dorsal, lateral and mesial surfaces all with numerous subacute spines or tubercles. Merus with row of subacute spines on ventromesial margin, ventrolateral margin not distinctly delimited. Right cheliped with surfaces of dactyl tuberculate, mesial face (Figure 3c) with covering of tiny to very small tubercles, occasionally almost obsolete and with weak longitudinal sulcus. Palm with irregular double row of subacute spines on dorsomesial margin, dorsal and lateral surfaces tuberculate, lateral face also with sulcus or concavity. Carpus with row of subacute spines on dorsomesial margin; dorsal and lateral surfaces tuberculate. Merus with row of 

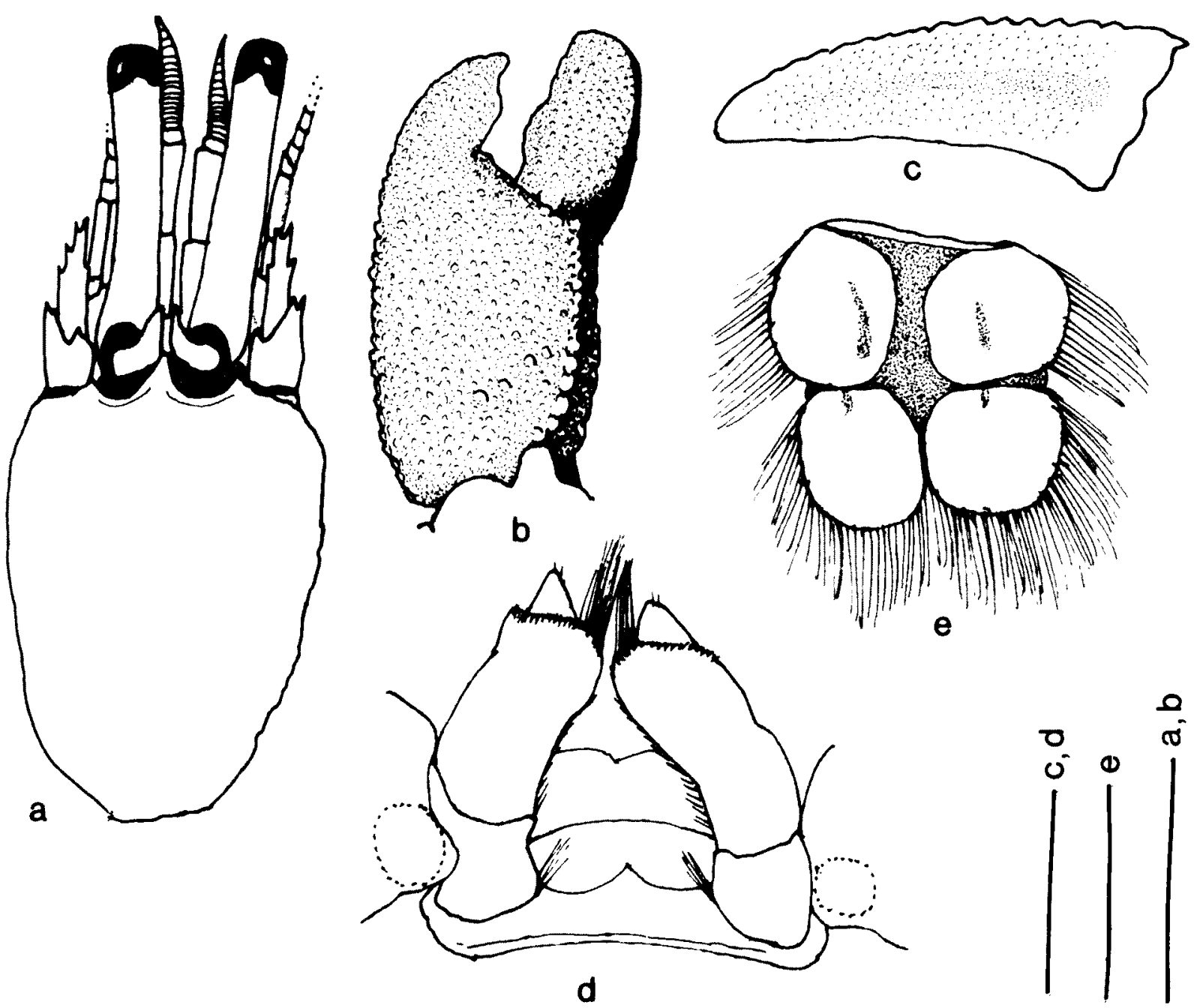

Figure 3 Paguristes purpurantennatus Morgan, 1987d, a-c, female (8.7 mm) (WAM C 18098), d, e, male (10.7 mm) (WAM C 9362). a, shield and cephalic appendages (aesthetascs and setae omitted); $\mathbf{b}$, left chela (dorsal view, setae omitted); c, dactyl of right chela (mesial view, setae omitted); d, coxae and sternite of fifth pereopods and anterior pleonal somite with male first pleopods; e, telson. Scales equal $5 \mathrm{~mm}(\mathrm{a}, \mathrm{b}), 3 \mathrm{~mm}(\mathrm{e})$ and $2 \mathrm{~mm}$ $(c, d)$.

subacute or blunt spines on ventromesial margin; ventrolateral margin not delimited.

Dactyls of second and third pereopods varying from slightly to considerably longer than propodi, dissimilar; second and third right with lateral faces weakly convex, flattened or faintly concave; lateral face of third left moderately to deeply concave; dorsal surfaces each with acute dorsolateral margins, most prominent on third, each also with 3-5 irregular rows of small corneous spines, sometimes extending onto mesial faces, ventral surfaces each with row of 43-56 tiny corneous spinules becoming minute proximally. Propodi with 5-11 dorsal acute or subacute spines, weakest on third pereopods, occasionally also with few small, scattered dorsomesial spines; ventral surfaces each with row of small spinules or spinulose protuberances. Carpi each with row of acute or subacute spines dorsally, most prominent and numerous on second pereopods, 1 or 2 spines on each lateral face on or near distal margin, each also with weak longitudinal sulcus. Meri each with dorsodistal spine, more prominent on third pereopods, dorsal surfaces unarmed or occasionally with few spinules or spinulose protuberances; ventral surfaces each with row of small subacute spines or spinulose tubercles, 1 or 2 tuberculate spines at distolateral angle. Fourth pereopods without preungual process at base of claw; dactyl with small corneous spine on dorsal surface concealed by tuft of setae, 1 or 2 smaller corneous spines or spinules on lateral face; dactylar rasp with 4-7 corneous scales. Propodal rasp consisting of 4 or 5 rows of corneous scales.

Male first pleopods (Figure 3d) each with single row of hook-like spines on inferior lamella; external lobe slightly exceeding distal margin of inferior lamella; internal lobe very short. Male second pleopods each with naked elongate basal segment; endopod with marginal setae distally and terminal 
tuft of longer setae; appendix masculina with long marginal and surface setae. Female brood pouch elongate, subtriangular, at least partially covering eggs attached to pleopods 2-4.

Telson (Figure 3e) with posterior lobes roundly subquadrate, left lobe slightly larger; margins of both lobes unarmed but fringed with long setae

\section{Colour (in life)}

"Shield bright red or red/brown, thorax slightly paler. Ocular peduncles orange or red, corneas black, ocular acicles orange or red. Antennular and antennal peduncles and flagella lilac or purple. Dactyls of chelipeds cream or white, sometimes tinged with pink, sometimes with pale small orange dots; propodi of chelipeds similar to dactyls, often tinged red-orange proximally; carpi and meri redorange with white spines and tubercles. Pereopods cream or orange with numerous red or deep pink short longitudinal flecks. Very small individuals paler, pereopods cream with orange flecks" (Morgan, 1987d).

\section{Habitat}

Generally inhabiting shallow subtidal waters, usually in association with rocky reefs, 0-6 $\mathrm{m}$, occasionally deep water to $154 \mathrm{~m}$.

\section{Distribution}

Western Australia.

\section{Remarks}

One juvenile female $(3.4 \mathrm{~mm})$ lacking the right cheliped and second right pereopod was identified as $P$. purpurantennatus on the basis of the contour of the left chela, general structure of the left third pereopod, and the shape and lack of armament of the telson. Although Morgan (1987d) reported five juveniles in the type series, he did not discuss growth-related variation. The present female was judged to be a juvenile because only small gonopores were apparent on the coxae of the third pereopods; no indication of first pleopod development was observed. The left cheliped had more prominent tuberculate spines on the dorsomesial margin of the chela and the dorsal surface and margins of the carpus than seen in larger individuals. When compared with similar juveniles of $P$. frontalis, the chela of the present specimen was appreciably narrower and subrectangular in overall shape. The dactyls of the ambulatory legs were also proportionally longer and narrower than observed in P. frontalis

As previously indicated, $P$. purpurantennatus and $P$. trontalis are clearly closely related species. In his description of $P$. purpurantennatus, Morgan (1987d) noted that there had been some initial uncertainty as to which of the two species had been originally described by H. Milne Edwards (1836), but concluded that Baker's (1905) description and specimens of $P$. frontalis confirmed the accuracy of Morgan's (1987d) designations of the two. Morgan (1989) indicated that not only did the distributional ranges of the two species overlap in southwestern Australia, but that a specimen of $P$. purpurantennatus had been collected in one locality from which $P$. frontalis had been found previously. One can only wonder if in the southern portion of its range, $P$. purpurantennatus is displacing $P$. frontalis.

In addition to the similarities in overall morphology of the two species mentioned by Morgan (1987d), the rather distinctive form of the telson and the male first gonopods set this speciespair, $P$. frontalis $-P$. purpurantennatus, apart from all other Australian species. Although it has not been possible to assess morphological variation in $P$. purpurantennatus to the extent done for $P$. frontalis, there can be no question that the two taxa warrant specific rank. One major difference, for example, is seen in the number of spinules on the ventral margins of the dactyls of the second and third pereopods. Spine number appears to increase with animal size in both species. However, even in the largest specimen of $P$. frontalis examined, which was considerably larger than any of the specimens of $P$. purpurantennatus available, the number of corneous spinules on the dactyls did not approach the numbers observed in $P$. purpurantennatus. Differences in the form of the chelipeds and ambulatory dactyls are not quantifiable, but exist nevertheless. Unfortunately, it is not possible to even speculate as to whether one represents a species that over time diverged from the other, or whether both have arisen as sister species from a common ancestor.

Morgan (1987c) reported that development in $P$. frontalis was abbreviated, with eggs hatching at the megalopal stage. His specimen, a relatively large female with a shield length of $18.2 \mathrm{~mm}$, carried 345 eggs and 309 megalopae in the brood pouch. Morgan indicated that the eyed eggs were subspherical and measured $1.7-1.9 \mathrm{~mm}$ on the long axis. Development in $P$. purpurantennatus is not known, but the ovigerous female $(15.7 \mathrm{~mm})$ from Frenchman's Bay carried many non-eyed, spherical and subspherical eggs measuring $1.2-1.5 \mathrm{~mm}$. Considering the probable increase in egg size with increasing development, it is very possible that $P$. purpurantennatus will also be found to have abbreviated development.

Paguristes alcocki McLaughlin and Rahayu, 2005 Figures 4, 5

Paguristes ?ciliatus. - Alcock 1905: 34. Not Paguristes ciliatus (Heller, 1862). 


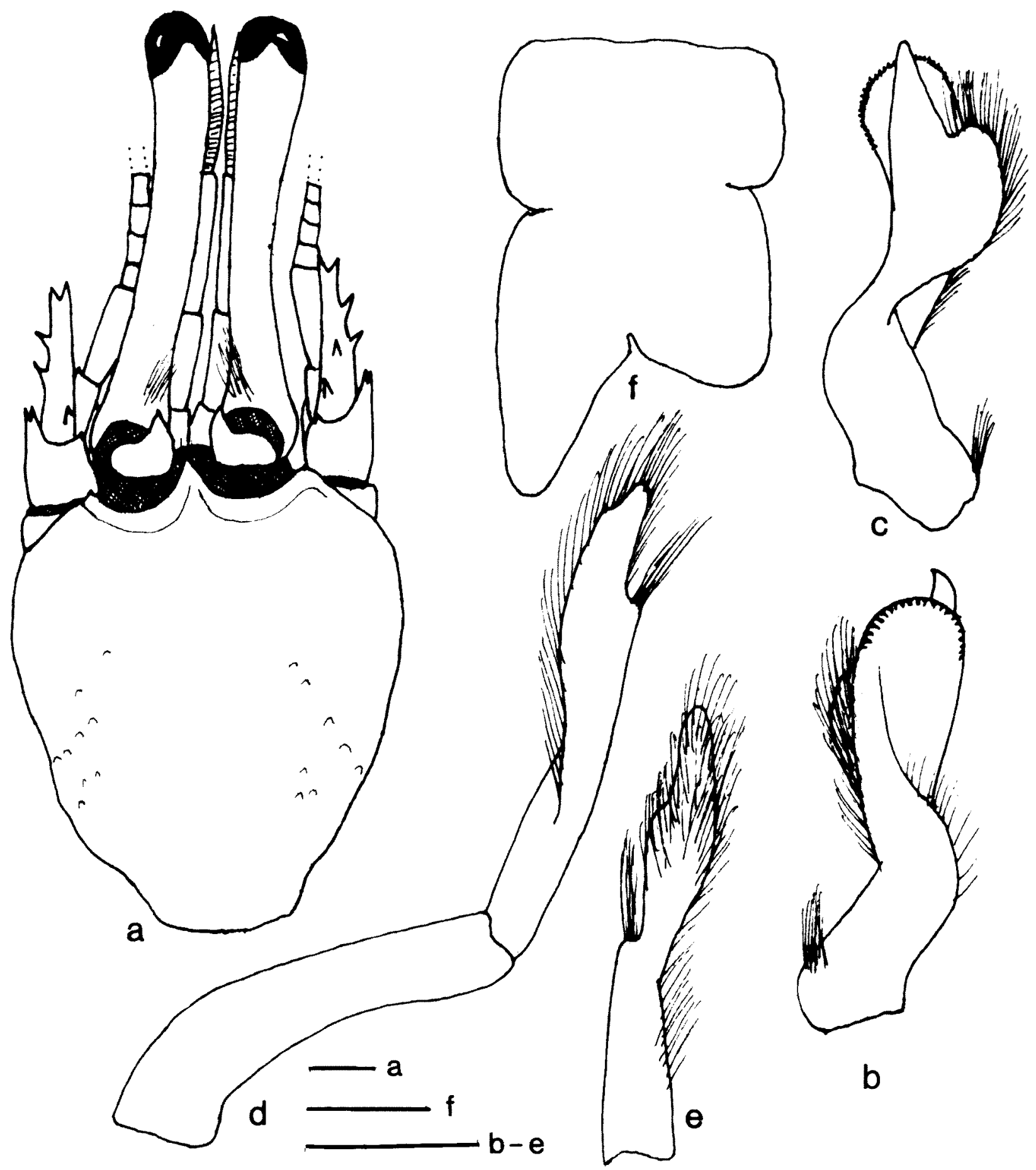

Figure 4 Paguristes alcocki McLaughlin and Rahayu, 2005, a, f, male holotype (7.8 mm) (WAM C 29554); b-e male paratype (7.5 mm) (WAM C 16493). a, shield and cephalic appendages (aesthetascs and most setae omitted); b, c, male left first pleopod; $\mathbf{d}$, male left second pleopod; e, distal segment of male left second pleopod; $\mathbf{f}$, telson (setae omitted) [from McLaughlin and Rahayu (2005)]. Scales equal $1 \mathrm{~mm}$.

Paguristes ciliatus. - Gordan, 1956: 321 (in part; literature). - Wang and Tung, 1982: 369 (list). Haig and Ball, 1988: 176. - Wang, 1992: 59 (list). - Wang, 1994: 568. - Rahayu, 2000: 392. Not Paguristes ciliatus (Heller, 1862).

Paguristes alcocki McLaughlin and Rahayu, 2005: 4, figs $1-3$.

\section{Material examined}

\section{Holotype}

Western Australia, Dampier Archielago. WAM C 29554 (ex WAM C 16493) (male, $7.8 \mathrm{~mm}$ ), $33 \mathrm{n}$. mls $N$ of Rosemary I. $\left(19^{\circ} 55^{\prime} \mathrm{S}, 116^{\circ} 36^{\prime} \mathrm{E}\right), 58 \mathrm{~m}$, 29.11.1982. 


\section{Paratypes}

Western Australia, Dampier Archielago. WAM C 16862, WAM C 16493 (1 male, 6.3 mm; 1 male, 7.5 $\mathrm{mm}$; respectively), $33 \mathrm{n} . \mathrm{mls} \mathrm{N}$ of Rosemary $\mathrm{I}$. $\left(19^{\circ} 55^{\prime} \mathrm{S}, 116^{\circ} 36^{\circ} \mathrm{E}\right), 58 \mathrm{~m}, 29.11 .1982$; WAM C 16751 (1 ovig. female, $5.5 \mathrm{~mm}$ ), $39 \mathrm{n}$. mls $\mathrm{N}$ of Enderby 1 . (19 58.1'S, $\left.116^{\circ} 27.1^{\prime} \mathrm{E}\right), 58-59 \mathrm{~m}, 28.09 .1982$. Indonesia. RMNH D 51507 (1 male, $7.2 \mathrm{~mm}$ ), Wamsoi Lagoon, Padaido, Irian Jaya, 57-91 m, 04.02.1956. Philippine Islands. NMP (1 male, 8.6 $\mathrm{mm}$ ), Panglao Expedition, stn L43, off Pamilacan I., $\left(09^{\circ} 30^{\prime} \mathrm{N}, 123^{\circ} 05^{\prime} \mathrm{E}\right), 60 \mathrm{~m}, 02.07 .2004$.

\section{Abbreviated description}

Gills quadriserial; branchiostegites each with few spinules on distal margin and dorsal margin distally, concealed by moderately dense setae. Shield (Figure 4a) longer than broad; dorsal surface with few tubercles or subacute spines and sparse covering of setae. Rostrum slender, moderate to elongate, reaching beyond bases of ocular acicles and considerably overreaching lateral projections, terminating acutely or with tiny spinule. Lateral projections triangular, each with tiny terminal spine. Ocular peduncles 0.7 to equaling shield length, slender, each with sparse tuft of setae basally; corneal diameter 0.1 peduncular length. Ocular acicles subtriangular, terminating acutely or in terminal spine. Antennular peduncles not reaching to bases of corneas; basal segment with small spine on lateral face of statocyst lobe. Antennal peduncles not exceeding 0.5 of ocular peduncles; fourth segment with small dorsodistal spine; third segment with moderately dense setae laterally, ventrodistal margin drawn out into acute spine; second segment with dorsolateral distal angle produced, terminating in bifid spine, lateral and ventral surfaces with dense long setae, dorsomesial distal angle with small spine; first segment unarmed. Antennal acicle not quite to nearly reaching to distal margin of fifth peduncular segment, terminating in prominent bifid spine; 2 spines on lateral margin, 1 or 2 spines on dorsal surface mesially and scattered setae not concealing armature. Antennal flagellum slightly shorter to longer than carapace; articles each with 1 to few short setae.

Chelipeds subequal to unequal, somewhat dissimilar; left slightly to noticeably larger and more subovate. Left cheliped (Figure 5a) with dactyl approximately twice length of palm; dorsomesial margin delimited only distally by short row of acute small spines, dorsal surface with numerous, scattered small tubercles and irregular row of slightly larger tuberculate spines mesiad of midline to closely-packed and somewhat flattened tubercle; mesial face (Figure 5b) with ventroproximal unarmed area, remainder of surface with irregular, almost transverse, rows of small sometimes comeous-capped, tubercles and small spines, obscured by covering of moderately short, dense setae; with or without very slight hiatus between dactyl and fixed finger. Palm with row of moderately small simple to multifid spines on dorsomesial margin, convex dorsal surface with covering of flat, or slightly swollen, scale-like plates, each usually with 1-3 tiny, comeous-tipped spinules, dorsolateral margin not distinctly delimited or with row of small tuberculate spines, becoming more prominent and acute distally on fixed finger and concealed by moderately dense long setae; mesial face with row of very small, sometimes spinulose, tubercles adjacent to distal margin and parallel, subdistal row of larger flattened tubercles, 1 additional large, flattened and corneous-capped tubercle dorsally in midline; lateral face of palm and fixed finger with scattered spinulose tubercles, ventral surface with irregular, transverse rows of spinulose tubercles, decreasing in size on fixed finger and accompanied by tufts of setae. Carpus with row of moderately prominent spines on dorsomesial margin, distal margin with row of small, tuberculate spines, extending onto lateral face; dorsolateral margin not delimited, dorsal and lateral surfaces with numerous, but not dense, small tuberculate spines, 1 larger spine in midline proximally; mesial face with parallel distal and subdistal row of small spinulose tubercles or projections, partially obscured by tufts of long setae, remainder of surface with low, spinulose and corneous-capped tubercles, continued onto ventral surface and accompanied by tufts of setae. Merus with row of spines on distal margin extending onto lateral and mesial faces, dorsal surface with subdistal short, transverse row of spines also extending onto lateral and mesial faces, remainder of dorsal margin with row of spines decreasing in size proximally and becoming obsolete; mesial face spinulose, ventromesial margin with double row of small, spinulose tubercles or tuberculate spines and dense tufts of setae; lateral face spinulose, at least ventrally, ventrolateral margin with double row of small, tuberculate spines obscured by long dense setae.

Right cheliped (Figure 5c) with dactyl 1.7 to twice length of palm; dorsomesial margin with row of moderately small, corneous-tipped spines, decreasing in size distally; dorsal surface with numerous quite small, sometimes corneous-tipped, tuberculate spines; cutting edge with row of very small calcareous teeth in proximal 0.7 , conneous teeth distally, terminating in small corneous claw; mesial face (Figure $5 \mathrm{~d}$ ) with numerous corneouscapped tubercles, forming 2-4 irregular longitudinal rows proximally, 1-2 rows distally and scattered tufts of setae. Palm with row of 4-6 moderate to very prominent spines on dorsomesial margin, dorsolateral margin not delimited, dorsal 
surface of palm and fixed finger with irregular semi-transverse rows of small, tuberculate or flattened, sometimes corneous-tipped spines or tubercles, each often accompanied by circlet of very short setae, spination partially obscured dorsolaterally by dense short to moderately long setae; mesial face of palm with subdistal vertical row of low, large tubercles and tufts of setae, additional large tubercles in midline dorsally; ventral surface with numerous low protuberances and tufts of setae; lateral surface of palm and fixed finger with covering of spinulose or flattened tubercles and/or small, sometimes corneous-tipped spines, almost completely concealed by dense, moderately short setae. Carpus with row of prominent spines on dorsomesial margin, dorsodistal margin with row of spinules, extending onto lateral face; dorsolateral margin not delimited, dorsal surface and lateral face each with numerous small, tuberculate, sometimes corneous-tipped spines; mesial face tuberculate and with subdistal row of larger tuberculate spines partially concealed by tufts of dense setae; ventral surface weakly tuberculate and with distal tufts of dense setae. Merus with row of spines on distal margin extending onto lateral and mesial faces, dorsal surface with short, transverse row of subdistal spines also extending onto lateral face, remainder of dorsal surface with row of spines decreasing in size proximally and becoming obsolete; ventromesial margin with row of tuberculate spines and tufts of moderately long setae; lateral surface spinulose, ventrolateral margin with row of small spines distally becoming double to triple row of spinulose tubercles proximally, partially obscured by tufts of dense, moderately short setae.

Second and third pereopods (Figure $5 \mathrm{e}-\mathrm{h}$ ) differing somewhat in armature. Dactyls 1.6-2.0 longer than propodi; dorsal margins each with row of corneous-tipped small spines (second) or very small spines or tubercles (third) and long, moderately stiff setae; ventral margins each with 11-22 corneous spines, concealed by long, stiff setae; lateral faces of second each with 1-3 rows of tufts of short setae, lateral faces of third each also with 1-3 rows of sparse tufts of short to moderate setae and occasionally corneous spinules; mesial faces of second each with shallow sulcus in proximal half, ventral margin cut into row of weak, spiniform sometimes tuberculate scutes, mesial faces of third with 3 or 4 rows of corneous spinules. Propodi of second pereopods each with irregular row of prominent spines on dorsal surface partially obscured by tufts of long setae, third pereopods each with dorsal row of low protuberances and few small spines also partially concealed by tufts of setae; ventral margins of second pereopods each with row of small spines and tufts of setae, third with tufts of setae; mesial faces of second pereopods each with numerous scattered tubercles and short, transverse rows of setae ventrally; third with few faint protuberances and ventral short, transverse rows of sparse tufts; lateral faces of second pereopods each with weak median longitudinal sulcus and scattered tubercles dorsally, third with few scattered tufts of setae. Carpi of second pereopods each with dorsal single or double row of prominent spines and tufts of long setae, third with prominent dorsodistal spine and small spines or protuberances and tufts of setae on remainder of dorsal surface; lateral faces of second pereopods each with additional cluster of small spines distally in dorsal half. Meri of second pereopods each with dorsal and ventral rows of small spines partially obscured by long setae, third unarmed, but with dense setae, particularly on ventral margins. Fourth pereopods each with small preungual at base of claw; no dorsodistal spine on carpus.

Male first pleopods (Figure $4 b, c$ ) each with tuft of setae on superior mesial angle of basal lobe; single row of small hook-like corneous spines on distal margin of inferior lamella; external lobe overreaching inferior lamella, internal lobe short, with marginal setae and moderately dense setal covering on inner surface. Second pleopods (Figure $4 \mathrm{~d}$, e) with basal segment glabrous; endopod with row of moderately long setae on mesial margin, distal angle with tuft of stiff setae; appendix masculina with long setae on distal margin and inferior surface. Female brood pouch large, fanshaped with margin weakly scalloped and provided with fringe of long, plumose setae. Eggs numerous, moderately small, diameter of non-eyed eggs 0.9 $1.1 \mathrm{~mm}$.

Telson (Figure 4f) with deep lateral incisions; median cleft small, shallow; posterior lobes markedly asymmetrical, terminal and lateral margins unarmed, but each with row of long setae.

\section{Colour (in life)}

"Shield mottled pink and darker reddish orange; ocular and antennular peduncles uniformly salmon pink, ocular acicles similar, but slightly lighter; antennal peduncles whitish-pink. Chelipeds with chelas orangish-pink with several whitish tubercles on mesial face; dorsal surfaces of carpi orangishpink distally, with irregular median transverse whitish band, mottled pink, red and white proximally and whitish tubercle; meri orangish-red and white distally, subdistal, irregular patch of pinkish-white dorsally, predominantly red to redorange in proximal halves; mesial faces each with prominent circular red patch dorsodistally, circumscribed by broad white ring, lateral faces each with similar, but somewhat less definitive patch. Second and third pereopods with dactyls predominantly orangish-red, each with whitish patch or band distally, narrow, irregular band 


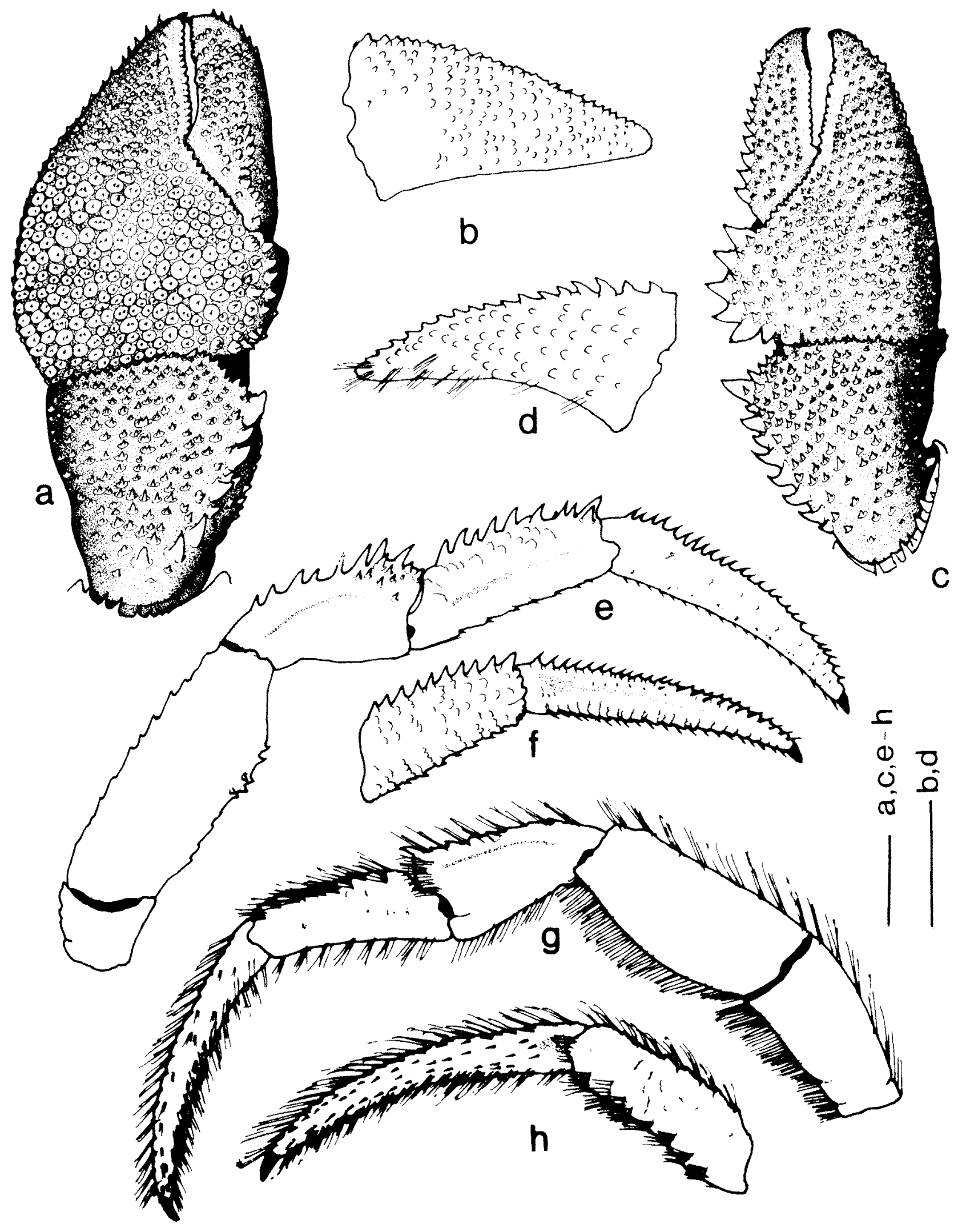

Figure 5 Paguristes alcocki Mclaughlin and Rahayu, 2005, holotype (7.8 mm) (WAM C 29554). a, chela and carpus of left cheliped (dorsal view, setae omitted); b, dactyl left chela (mesial view, setae omitted); $c$ chela and carpus of right cheliped (dorsal view, setae omitted); d, dactyl of right chela (mesial view, most setae omitted); e, right second pereopod (lateral view, setae omitted); factyl and propodus of right second pereopod (mesial view, setae omitted); $g$, left third pereopod (lateral view); $h$, dactyl and propodus of left third pereopod (mesial view) [from McLaughlin and Rahayu (2005)]. Scales equal $2 \mathrm{~mm}$. 
proximally, and sometimes light colored patch dorsomesially; propodi, carpi and meri each with irregular narrow whitish band proximally and broader whitish band distally, median areas red with scattered white spots" (McLaughlin and Rahayu, 2005). In preservative: Australian specimens each with moderately large spot of reddish-orange distally on mesial and lateral faces of meri of chelipeds; meri, carpi, and propodi of second and third pereopods each with median band of reddish-orange; dactyls each with subproximal and subdistal similar bands.

\section{Habitat}

One paratype inhabited a shell entirely covered by a calcareous bryozoan.

\section{Distribution}

Western Australia; Indonesia; Philippine Islands, and possibly also from the South China Sea and Persian Gulf; $58-91 \mathrm{~m}$, perhaps to $110 \mathrm{~m}$.

\section{Variation}

As noted by McLaughlin and Rahayu (2005), the chelipeds of the holotype and larger paratypes can be categorized as unequal, as the size differences between the right and left are substantial, whereas the chelipeds of the female and smallest male paratype can be described as subequal. The data, based only on five males and one ovigerous female, are too meager for anything other than speculation, but it does seem possible that in $P$. alcocki, the degree of cheliped asymmetry is a function of growth.

\section{Affinities}

Among Australian species of Paguristes, $P$. alcocki appears most closely allied to $P$. kimberleyensis, sharing with that species the tendency toward dissimilarities in the size and armature of the chelipeds. However, as indicated in the discussion of variation, cheliped inequality appears to be a function of growth in $P$. alcocki, whereas in $P$. kimberleyensis the differences between the right and left chelipeds are consistent regardless of animal size or sex. The two species may be distinguished by the armature of the mesial faces of the dactyls of the chelipeds that in $P$. alcocki consists of a covering of small spines or spinules in irregular rows, but in $P$. kimberleyensis of one or two longitudinal rows of small spines. Additionally, but subject to more variation, the ocular peduncles of $P$. alcocki are longer and more slender; the armature of the dorsal surface of the left cheliped consists of more flattened, scale-like tubercles, and the external lobe of the male first gonopod is better developed. Although colouration in $P$. kimberleyensis is known only from preserved specimens, even in preservative, the meri of the chelipeds of $P$. alcocki each retains the ovate patch of orange at least on the mesial face. No such patch has been seen in any of the specimens of $P$. kimberleyensis.

If McLaughlin and Rahayu's (2005) proposition that $P$. alcocki truly represents Alcock's (1905) $P$. ? ciliatus, this species is also closely allied to $P$. balanophilus Alcock, 1905. Both Alcock (1905) and Morgan and Forest (1991a) described the armature of the chelipeds of $P$. balanophilus as similar; however, Rahayu and McLaughlin (2006) noted some dissimilarities. The latter authors differentiated the two species by the armature of the mesial faces of the dactyls of the chelipeds: several irregular rows of small spines or spinules in $P$. alcocki, but only one or two rows of more prominent spines in $P$. balanophilus.

\section{Paguristes kimberleyensis Morgan and Forest, 1991a}

Figure 6

Paguristes kimberleyensis Morgan and Forest, 1991a: 682, figs 14, 15. - Davie, 2002: 55.

\section{Material examined}

\section{Holotype}

Western Australia. WAM C 19215 (male, 3.2 $\mathrm{mm})$, stn 64, Fenelon I., N. Kimberley (14\%01'00"S. $\left.125^{\circ} 48^{\prime} 00^{\prime \prime} \mathrm{E}\right), 7-8 \mathrm{~m}, 18.07 .1988$.

\section{Other material examined}

Western Australia. WAM C 19216 (1 female, 3.3 $\mathrm{mm}$ ), Long Reef, N. Kimberley, 15 m, 18.07.1988; WAM C 27964 (ex WAM C 26020) (1 male, $3.3 \mathrm{~mm}$ ), stn DA2/99/73 (6 km S of $\left.29^{\circ} 40.14^{\prime} \mathrm{S}, 116^{\circ} 27.69^{\prime} \mathrm{E}\right)$, $12.5 \mathrm{~m}, 24.07 .1999$; WAM C 27996 (1 male, $4.7 \mathrm{~mm}$; 3 ovig. females, $2.9-3.9 \mathrm{~mm}$ ), stn DA3/99/56 (20³8.94'S, $\left.116^{\circ} 26.22^{\prime} \mathrm{E}\right), 2-11 \mathrm{~m}, 03.09 .1999$; WAM C 28010 (1 ovig. female, $3.8 \mathrm{~mm}$ ), stn DA3/99/65 (20 37.10'S, $\left.116^{\circ} 26.72^{\prime} \mathrm{E}\right), 13.0-15.0 \mathrm{~m}, 06.09 .1999$; WAM C 27998 (1 male, $4.5 \mathrm{~mm})$, stn DA3/99/56 (2028.94'S, $\left.116^{\circ} 26.22^{\prime} \mathrm{E}\right), 2-11 \mathrm{~m}, 03.09 .1999$.

\section{Abbreviated redescription}

Gills quadriserial; branchiostegites each with few to row of small spines on dorsal margin, decreasing in size proximally; anterior margins each with 1-3 spines. Shield (Figure 6a) slightly to distinctly longer than broad; dorsal surface prominently sculptured anteriorly (not illustrated); dorsolateral margins with few scattered small spines and sparse tufts of plumose setae. Rostrum usually well developed (Figure 6b), moderate to slender, slightly to considerably overreaching lateral projections and reaching proximal $0.3-0.6$ of ocular acicles, rarely only rounded lobe (Figure 6a) not reaching level of 


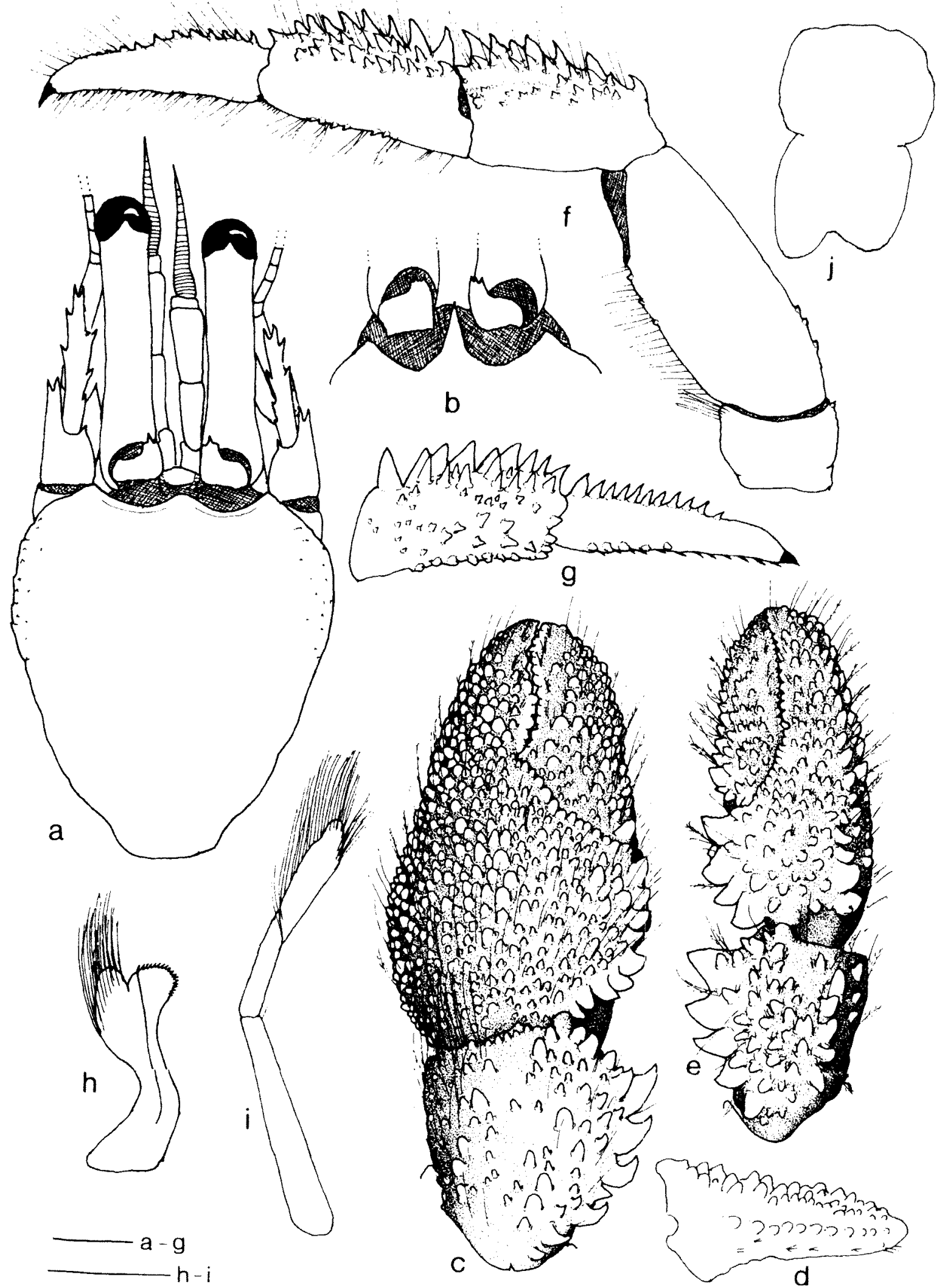

Figure 6 Paguristes kimberleyensis Morgan and Forest, $1991 \mathrm{a} ; \mathrm{a}, \mathrm{c}-\mathrm{f}, \mathrm{i}$, ovigerous female (3.8 mm) (WAM C 28010); b. g, hale ( $4.5 \mathrm{~mm}$ ) (WAM C 27998). a, shield and cephalic appendages (aesthetascs and setae omitted); $b$, anterior margin of shield, rostrum and bases of ocular peduncles (setae omitted); chela and carpus of left cheliped (dorsal view); d, dactyl of left chela (mesial view); e, chela and carpus of right cheliped (dorsal view); $\mathbf{f}$, left second pereopod (lateral view); $\mathbf{g}$, dactyl and propodus of left second pereopod (mesial view. setae omitted); $h$, male left first pleopod; $i$, male left second pleopod; $j$, telson (setae omitted). Scales equal 1 $\mathrm{mm}$. 
lateral projections; with terminal spinule or rarely unarmed. Lateral projections broadly triangular, each usually with small spine. Ocular peduncles $0.7-0.8$ length of shield, left often slightly longer, dorsomesial surfaces with few sparse tufts of moderate to long setae; corneal diameter $0.1-0.2$ of peduncular length; ocular acicles each with 1-3 spines. Antennular peduncles reaching only to basal corneal margins or nearly to distal margins of corneas; basal segments each with 1 or 2 spines on lateral face. Antennal peduncles reaching to or slightly beyond midlength of ocular peduncles, but not reaching to bases of corneas; fourth segment with dorsodistal spine; third segment with well developed ventrodistal spine; second segment with dorsolateral distal angle produced, terminating in bifid spine, occasionally with additional spine on lateral margin and few simple or plumose setae, dorsomesial distal angle with small spine; first segment with small ventrodistal spine. Antennal acicles reaching nearly to distal margin of ultimate peduncular segment, occasionally slightly shorter; terminating in bifid spine, 1-3 spines on lateral margin distally and 1-4 spines on mesial margin proximally and with long simple and plumose setae. Antennal flagella slightly shorter to slightly longer than carapace.

Chelipeds unequal and dissimilar, left (Figure 6c) larger and more robust. Left cheliped with dactyl 1.2-1.5 length of propodus, cutting edge with row of small calcareous teeth, terminating in small corneous claw; with or without slender hiatus between dactyl and fixed finger; dorsomesial margin with irregular row of small to moderately large, usually tuberculate spines or spinulose tubercles, largest proximally, armature of dorsal surface varying from few scattered small tubercles in holotype to having numerous tubercles in Dampier specimens, densest mesially; mesial face (Figure 6d) with few scattered tubercles and 1 distinct, albeit sometimes irregular, longitudinal row of blunt tubercles. Palm with irregular row of 4-9 small to moderate large, conical, acute or subacute spines on dorsomesial margin; dorsal and lateral surfaces with blunt or subacute tubercles, most closely packed laterally and on fixed finger, dorsolateral margin not delimited, but usually with 2-5 more prominent, tuberculate spines proximally, fringe of moderate to long plumose setae ventrolaterally; cutting edge of fixed finger with row of small calcareous teeth, terminating in small corneous claw; ventral surface of palm with several blunt subacute tubercles, 2 or 3 sometimes more prominent. Carpus with 5-7 large, usually tuberculate spines on dorsomesial margin; dorsal surface with scattered tubercles and subacute to acute small spines, most numerous mesially, distal margin dorsally and frequently also laterally with several spines and/or tubercles, occasionally 1 larger spine in midline; lateral, mesial and ventral surfaces all with scattered tubercles. Merus with row of spines or spinulose protuberances on dorsal margin, largest subdistally; ventrolateral and ventromesial margins each with row of small to moderately large spines or subacute tubercles, lateral face often tuberculate or spinulose. Segments with tufts of long plumose and simple setae, particularly dorsolaterally and dorsomesially and shorter setae at bases of numerous tubercles.

Right cheliped (Figure 6e) somewhat shorter to approximately as long as left, but appreciably narrower. Dactyl 1.5-2.0 length of palm; dorsomesial margin with row of short, stout spines, dorsal surface with scattered subacute and spinulose tubercles; mesial and ventral surfaces with scattered tubercles; cutting edge with row of small calcareous teeth; no hiatus between dactyl and fixed finger. Palm with 4 or 5 large spines on dorsomesial margin, dorsal face with numerous subacute spines and/or blunt tubercles, often less dense on fixed finger; dorsolateral margin with row of spines extending nearly to tip of fixed finger; lateral face with numerous tubercles; ventral surface of palm with several blunt and subacute tubercles, 2 sometimes larger in midline. Carpus with 5 or 6 large spines on dorsomesial margin; dorsal surface with numerous tubercles or subacute spines, dorsolateral margin with irregular row of smaller subacute spines; other surfaces with scattered tubercles and subacute spines. Merus with row of spines or spinulose protuberances on dorsal margin decreasing in size proximally; ventrolateral and ventromesial margins each with row of spines or spinulose tubercles. Tufts of long plumose and simple setae on all segments, most numerous on dorsomesial and dorsolateral margins, often shorter setae at bases of tubercles.

Second pereopods (Figure 6f, g) appearing somewhat sexually dimorphic. Dactyls 1.1-1.2 longer than propodi; dorsal margins each with row of small spines, becoming obsolete distally in larger individuals; ventral margins each with 10-13 corneous spines and usually with additional row of distinct scutes or quite small calcareous spines in females and small males, at least on left dactyl; ratio of width to length 0.2 in males, but $0.3-0.4$ in females. Propodi each with row of 7 or 8 prominent spines on dorsal margin and frequently 1-3 irregular rows of smaller spines; ventral margins cut by row of scutes in holotype and small males and females or with protrusions at setal bases giving irregular outline in larger males, additional row of spines in females, most prominent on left; mesial faces and distomesial margins spinulose in females and small males, armature most prominent on left. Carpi each with row of 5-7 spines on dorsal 
margin, frequently 1 or 2 irregular additional rows, 1-3 additional spines at distolateral margin, and several spinules on lateral face. Meri each with low protuberances on dorsal margin, proximal few often developing into small spines; sometimes also small spine at dorsodistal margin; ventral margins each with few to row of several spines. Ischia each frequently with small dorsodistal spinule. All segments with long plumose setae along dorsal and ventral margins.

Third pereopods of similar length to second. Dactyls in both sexes with width/length ratio 0.2; dorsal margins unarmed or with few spinules; ventral margins each with low protuberances and row of 10-15 corneous spinules, decreasing in size appreciably in posterior half. Propodi of large males with dorsal and ventral margins unarmed, armament of ventral margins of smaller individuals varying from row of distinct scutes to row of small spines or spinules, at least on left. Carpi each with spine at dorsodistal angle, otherwise unarmed. Meri and ischia unarmed. Setation of third pereopods similar to second. Fourth pereopods each with preungual process at base of claw.

Male first pleopods (Figure 6h) each with row of long setae on mesial margin of basal segment; inferior lamella with row of setae on lateral margin, distal margin with 1 row of small hooked spines; external lobe distally rounded, not overreaching distal margin of inferior lamella; inner lobe moderately small, with long setae marginally and internally. Second pleopod (Figure 6i) with row of setae marginally on endopod, appendix masculina with moderately dense setae.

Females brood pouch large, weakly scalloped margin with fringe of very short setae. Eggs relatively few in number, circular, 0.6-0.9 $\mathrm{mm}$ diameter in early development, becoming elongate and roundly rectangular, $1.2-1.4 \mathrm{~mm}$ in length at eyed stage.

Uropods very asymmetrical; left much larger. Telson (Figure 6j) longer than broad, with shallow lateral indentations; left posterior lobe moderately to considerably larger than right, both subtriangular; lobes unarmed, margins with long simple setae.

\section{Colouration (in preservative)}

Shield, antennular and antennal peduncles mottled orange and white. Ocular peduncles faint orange, fading to greyish-white in distal halves; acicles orange with white terminally. Chelipeds and ambulatory legs mottled orange and white, dactyls of second and third pereopods each with band of white at base of claw (based on Dampier specimens).

\section{Habitat}

Sand and coral substrate; 7-59 $\mathrm{m}$.

\section{Distribution}

Dampier Archipelago to the Kimberley region, Western Australia.

\section{Variation}

The small Dampier male $(3.3 \mathrm{~mm}$ ) has protuberances on the second pereopods similar to the scutes seen in the specimens from the Kimberley region, but these are only very weakly apparent and already are associated more obviously with the ventral row of spines. These protuberances are replaced in the two larger males $(\mathrm{sl}=4.5,4.7 \mathrm{~mm})$ by small spines. The right chelipeds are also similar in the holotype of $P$. kimberleyensis and smallest male from the Dampier Archipelago, but the armature of this chela in the two larger males is appreciably more reduced. The four females collected during the Dampier Expedition show considerable variation in the strength of the armature of the chelipeds and ambulatory legs, but the patterns of spination of the second pereopods are similar to those seen in the larger Dampier males. Size differences not withstanding, the females are consistent in having broader dactyls and propodi of the second pereopods (lateral view). It is unclear from the small number of individuals known, whether the lack of rostral development seen in one female (Figure 6a) is an example of intraspecific variation or the result of injury.

\section{Affiinities}

As previously discussed, P. kimberleyensis appears most closely allied to P. alcocki. At least in smaller specimens, there is also a superficial similarity between $P$. kimberleyensis and $P$. squamosus in the scutellate markings on the mesial faces of the ambulatory legs. However, these two taxa are immediately distinguished by the differences in the shape and armature of the telsons, and by the similarity, symmetry and pilosity of the chelipeds of the latter.

\section{Remarks}

Paguristes kimberleyensis was described from a single small male that appeared very distinctive because of its dimorphic chelipeds and the scutes that were developed on the ventral surfaces of propodi of the second pereopods. At that time, Morgan and Forest (1991a) reported a small female also collected in the Kimberley region that was very similar to the male, but had simple ocular acicles, a shorter, broader rostrum and similar chelipeds. The authors considered it unlikely that the characters exhibited by the female could represent only sexual dimorphism, and excluded it from assignment to $P$. kimberleyensis. That female has been reexamined. Although the right cheliped is now missing, a note on the label also indicates that when first examined, the chelipeds were similar in shape and spination. 
The remaining left cheliped is considerably narrower than the left chelipeds of the holotype and the Dampier specimens, and in having a dorsolateral row of spines extending almost the entire length of the fixed finger, distinctly resembles the right cheliped of these latter specimens. It is suggested that the reason for the initial similarity observed between the right and left chelipeds of this specimen is that the left cheliped is an appendage that has regenerated in the form of the right cheliped. Although not a common regenerative event, left-right reversal has been documented in a few paguroids (e.g., McLaughlin, 2004a). Variations in ocular acicle spination were documented for several Paguristes s.l. species by McLaughlin and Provenzano (1974; 1975), and is seen among the Dampier specimens of $P$. kimberleyensis. Similarly, not only has variation in rostral length between males and females of Paguristes palythophilus Ortmann, 1892 been reported by Komai (2001), considerable variation has been noted for $P$. puniceus by McLaughlin (2004b). As indicated above, one of the present Dampier specimens has a nearly obsolete rostral lobe.

Morgan and Forest (1991a) noted similarities between Lewinsohn's (1969) 'Paguristes sp. a' and $P$. kimberleyensis, but presumed that one difference setting the two taxa apart was the apparent similarities of the armature of the chelipeds in Lewinsohn's species. McLaughlin and Rahayu (2005) examined all of Lewinsohn's specimens remaining in the collections of the Museum of TelAviv University and reported that the chelipeds were somewhat dissimilar in armament as well as considerably different in size. In their description of Lewinsohn's Paguristes sp. as the new species $P$. lewinsohni McLaughlin and Rahayu, 2005, the authors reported that the armament of the mesial face of the dactyl of the left cheliped consisted of several irregular rows of small tubercles partially concealed by short setae. This character alone will distinguish $P$. lewinsohni from $P$. kimberleyensis in which the mesial face of the dactyl is armed with one primary row of blunt tubercles.

\section{Paguristes crinitimanus sp. nov.} Figures 7, 8

\section{Material examined}

\section{Holotype}

Queensland. QM (male, $16.3 \mathrm{~mm}$ ), off Cairns $\left(16^{\circ} 55.9^{\prime} \mathrm{S}, 151^{\circ} 34.6^{\prime} \mathrm{E}\right.$ to $\left.16^{\circ} 55.9^{\prime} \mathrm{S}, 151^{\circ} 34.6^{\prime} \mathrm{E}\right), 880$ $\mathrm{m}, 06.12 .1985$.

\section{Description}

Gills quadriserial; branchiostegites with few spinules on distal margin and dorsal margin distally, partially concealed by moderately dense setae. Shield (Figure 7a) slightly longer than broad; dorsal surface with scattered small spines and rows of moderately long setae laterally, few scattered tufts of shorter setae centrally. Rostrum elongate, slender, reaching well beyond bases of ocular acicles and distally bent downward, with terminal spinule, margins each with row of short setae. Lateral projections triangular, each with prominent marginal spine.

Ocular peduncles long, 0.7 shield length, slender, each with sparse tuft of setae basally and in irregular longitudinal row on dorsal surface; corneal diameter 0.2 of peduncular length. Ocular acicles moderately large, only weakly calcified in basal halves, acicular projections narrowly triangular, each terminating in well developed marginal spine; separated by approximately basal width of 1 acicle. Posterior carapace with posterior median plate moderately well calcified, median portions of posterior carapace laterad of sulci cardiobranchalis weakly calcified.

Antennular peduncles, when fully extended, not quite or just reaching to bases of corneas; ultimate and penultimate segments each with row of tufts of long setae on dorsal surface, ventral surface of right penultimate segment with small spine at midlength; basal segment with slender spine on lateral face of statocyst lobe and small spine at ventrodistal margin partially concealed by long setae.

Antennal peduncles not exceeding 0.5 of ocular peduncles; fifth segment with few tufts of setae; fourth segment with small dorsodistal spine; third segment with moderately dense setae, ventrodistal margin drawn out and terminating in small spine; second segment with dorsolateral distal angle produced, terminating in bifid spine and with numerous long setae, dorsomesial distal angle with small spine, mesial margin with setae, ventral surface practically obscured by dense, long setae; first segment with ventrolateral distal margin drawn out into prominent spine partially concealed by long setae. Antennal acicles reaching to proximal 0.3-0.6 of fifth peduncular segments, each terminating in prominent bifid spine; 1 or 2 spines on lateral margin, 5 or 6 spines on mesial margin, both margins with abundance of long setae not concealing armature. Antennal flagellum longer than carapace; articles each with 1 or 2 minute setae.

Coxae of third maxillipeds each with acute spines on ventrodistal and ventromesial margins; ischia each with well developed crista dentata; meri each with 6-8 spines on ventral margin, dorsodistal margin with small spine.

Chelipeds unequal but similarly armed; left cheliped (Figure $7 \mathrm{~b}$ ) appreciably larger and more subovate, armature at least partially concealed by long setae, particularly dense on lateral halves of palms and fixed fingers. Left chela with dactyl 


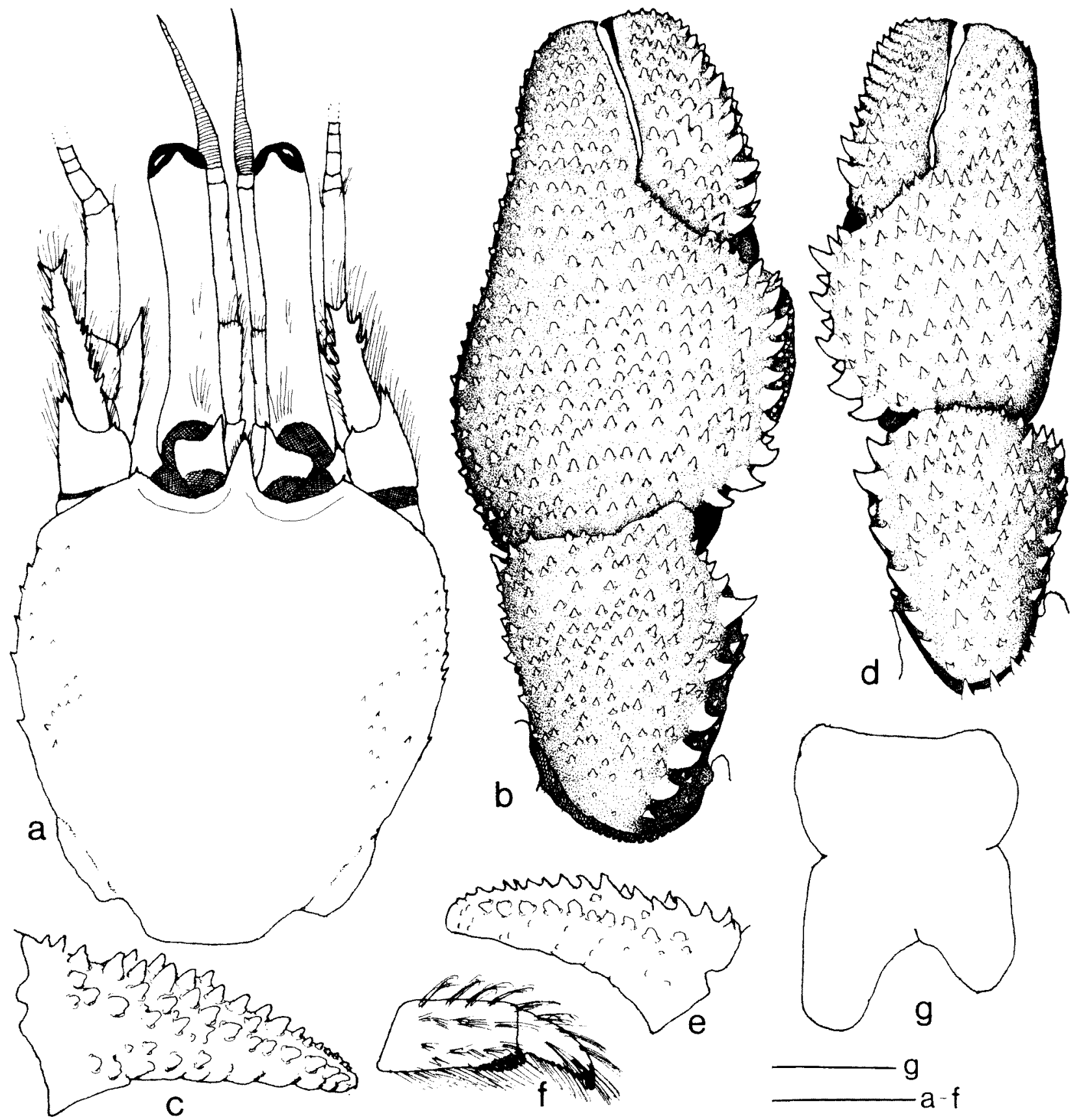

Figure 7 Paguristes crinitimanus sp. nov., male holotype $(16.3 \mathrm{~mm})(\mathrm{QM})$. a, shield and cephalic appendages (aesthetascs and some setae omitted); $\mathbf{b}$, chela and carpus of left cheliped (dorsal view; setae omitted); $\mathbf{c}$, dactyl of left chela (mesial view; setae omitted); $d$, chela and carpus of right cheliped (dorsal view; setae omitted); e, dactyl of right chela (mesial view; setae omitted); $f$, dactyl and propodus of right fourth pereopod (lateral view); $\mathrm{g}$, telson (setae omitted). Scales equal $5 \mathrm{~mm}$ (a-f) and $3 \mathrm{~mm}(\mathrm{~g})$.

approximately same length of palm; dorsomesial margin with row of prominent acute spines, dorsal surface with irregular, transverse rows of smaller spines and tufts of moderately dense, long setae; mesial face (Figure $7 \mathrm{c}$ ) with median row of prominent tuberculate spines and few additional tuberculate spines dorsally and ventrally; ventral surface with tufts of long setae; cutting edge with row on tiny calcareous teeth, replaced in distal 0.2 by corneous teeth, terminating in moderately prominent corneous claw. Palm with row of prominent acute spines on dorsomesial margin, decreasing in size distally; convex dorsal surface with transverse rows of moderate to small, acute and subacute spines, partially to almost completely concealed by rows of dense long setae; dorsolateral margin not delimited, rows of spines continuing onto lateral surface dorsally; mesial face with scattered tuberculate spines, largest dorsally, accompanied by sparse tufts of setae; ventromesial and ventrolateral faces not delimited, rounded ventral surface with scattered spinulose tubercles, 
largest laterally and accompanied by tufts of setae. Carpus with row of prominent spines on dorsomesial margin in proximal 0.7 , smaller spines in distal 0.3; distal margin with row of small spines most numerous on lateral face; dorsolateral margin not delimited, dorsal and lateral surfaces with not particularly dense covering of small spines not concealed by accompanying long, moderately dense setae; mesial face with distal row of tiny spinules, irregular rows of small tubercles subdistally and dorsally; ventrodistal margin with row of tubercles. Merus with row of spines on distal margin, largest dorsally, most numerous on lateral face, fewer and smaller on mesial face; dorsal surface with subdistal transverse row of tuberculate spines extending onto lateral and mesial faces dorsally, remainder of lateral face tuberculate, ventrolateral margin with irregular, double row of small spines; mesial face tuberculate ventrally, ventromesial margin delimited by short row of spines only distally and proximally, median marginal area rounded and tuberculate; ventral surface tuberculate. Ischium with row of small tubercules on ventromesial margin, ventrolateral margin with few spinules. Coxa with small spines on ventrodistal and ventromesial margins, ventral surface tuberculate.

Right cheliped with chela (Figure $7 \mathrm{~d}$ ) subrectangular (in dorsal view), and dactyl slightly longer than palm; dorsomesial margin with row of spines, decreasing in size distally; dorsal surface with transverse rows of small spines accompanied by long, dense setae; cutting edge with row of tiny calcareous teeth in proximal 0.8 , corneous teeth distally, terminating in small corneous claw; mesial face (Figure $7 \mathrm{e}$ ) with median row of tuberculate spines, some corneous-tipped and few tufts of setae. Palm with row prominent spines on dorsomesial margin, dorsolateral margin weakly delimited by row of smaller spines almost entirely concealed by long dense setae, dorsal surface of palm and fixed finger with irregular transverse rows of small spines partially to almost completely obscured by dense long setae; cutting edge of fixed finger with row of tiny calcareous teeth, terminating in small corneous claw; mesial face of palm with dorsal row of moderately large tubercles and smaller tubercles ventrally; lateral faces of palm and fixed finger densely tuberculate; ventral surface with scattered low protuberances, largest and spinulose laterally and accompanied by sparse tufts of setae. Carpus with row of prominent spines on dorsomesial margin, distal margin with row of corneous-tipped spines extending down entire length of lateral face; dorsolateral margin weakly delimited by row of moderately small spines, dorsal surface with numerous small spines only partially obscured by long setae; lateral face with irregular rows of small, sometimes corneous-tipped spines; mesial face with row of tiny tubercles on distal margin, surface with scattered tubercles, largest dorsally and sparse tufts of setae. Merus with row of spines on distal margin extending onto lateral and mesial faces, dorsal surface with short, transverse row of subdistal spines also extending onto lateral face, remainder of dorsal surface with row of corneous-tipped spines decreasing in size proximally; ventromesial margin with few spines distally, remainder of margin rounded and tuberculate; lateral surface spinulose, ventrolateral margin with row of small spines distally, becoming double to triple row of spinulose tubercles proximally and accompanied by moderately sparse, long setae; ventral surface with tubercles and sparse long setae. Ischium with row of small spines and sparse tufts of setae on ventromesial margin. Coxa with row of minute spinules on ventrodistal margin, cluster of small spines at ventromesial distal angle and few spinules on ventral surface.

Second and third pereopods (Figures 8a-d) differing somewhat in armature and setation. Dactyls approximately 1.3 (second) and 1.6 (third) longer than propodi, third strongly twisted; dorsal margins each with short row of small spines (second) or low protuberances (third), both with rows of tufts of long, moderately stiff setae; ventral margins each with row of very small corneous spinules, 24-25 (second) or 14-15 in distal half (third), concealed by tufts of long setae; lateral faces of second each with short longitudinal sulcus proximally and dorsal, median and ventral rows of tufts of moderately long setae, lateral faces of third ventrally angular, each with longitudinal sulcus in proximal half, dorsal and median rows of very short setae; mesial faces of second each with shallow sulcus proximally and moderately dense covering of tufts of long setae, mesial faces of third each with shallow median sulcus in proximal 0.6, dorsal, median and ventral rows of tufts of setae. Propodi of second pereopods each with row of prominent spines and few accessory smaller spines on dorsal surface partially obscured by tufts of setae, third pereopods with row of low protuberances distally and few small spines proximally, also partially concealed by tufts of setae; ventral margins of second pereopods each with row of small spines and tufts of setae, third with tufts of setae; mesial faces of second pereopods each with numerous low, sometimes spinulose ridges and tufts of setae dorsally and medianly, row of short, transverse, spinose or tuberculate scutes and long setae ventrally; third with tufts of short setae dorsally and ventral row of short, transverse sometimes spinulose ridges and long setae; lateral faces of second pereopods each with numerous short ridges and tufts of long setae, third with scattered pits and tufts of short setae. Carpi of second pereopods each with dorsal nearly double row of prominent spines and tufts of long setae, third with prominent 


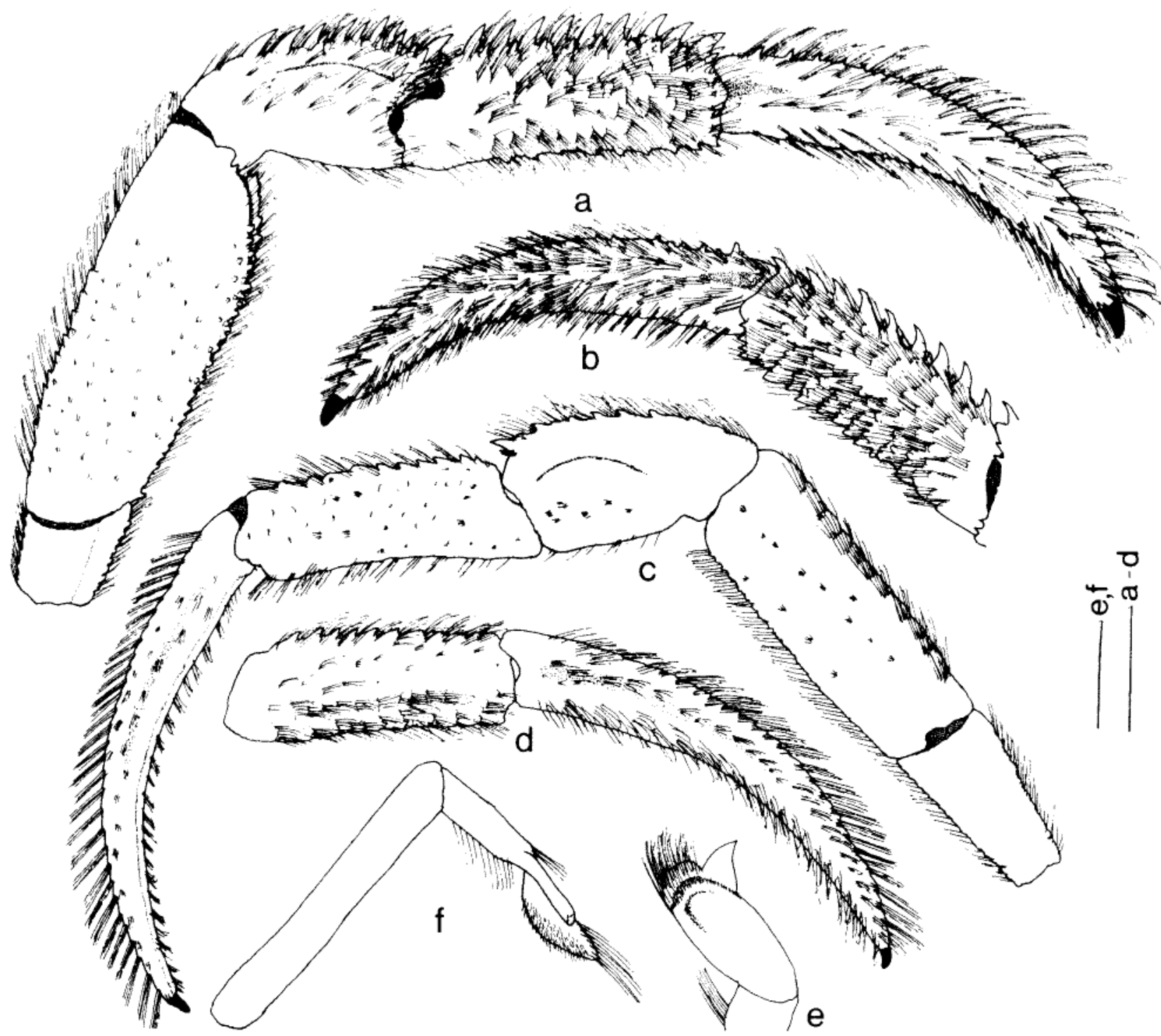

Figure 8 Paguristes crinitimanus sp. nov., male holotype (16.3 mm) (QM). a, right second pereopod (lateral view); b, dactyl and propodus of right second pereopod (mesial view); c, left third pereopod (lateral view); d, dactyl and propodus of left third pereopod (mesial view); e, male left first pleopod; $f$, male left second pleopod; Scales equal $5 \mathrm{~mm}(\mathrm{a}-\mathrm{d})$ and $2 \mathrm{~mm}(\mathrm{e}, \mathrm{f})$.

dorsodistal spine and smaller spines and tufts of setae on remainder of dorsal surface; lateral faces of second pereopods each with additional 2 or 3 small spines distally in dorsal half. Meri of second pereopods each with dorsal and ventral rows of small spines and tufts of long setae, third with dorsal margins unarmed, but row of small tubercles on each ventral margin accompanied by long setae. Ischia and coxae of second pereopods each with row of very small spines on ventromesial margin; third unarmed. Fourth pereopods (Figure 7f) each with moderately long preungual at base of claw; no dorsodistal spine on carpus.

Male first pleopods (Figure 8e) each with double row of small corneous spines distally on inferior lamella, becoming single row on inner margin; external lobe overreaching inferior lamella when extended, but curled distally in situ, internal lobe overreaching distal margin of inferior lamella, with long setae on margin and inner face. Second pleopods (Figure 8f) with proximal segment glabrous; endopod with row of setae on inner margin and tuft at distal angle; appendix masculina with long setae on outer margin and very short setae on inner margin and surface. Female unknown.

Telson (Figure 7g) with moderately deep lateral incisions; median cleft narrow, shallow; posterior lobes markedly asymmetrical, terminal and lateral margins unarmed, but each with row of long setae.

\section{Colour (in preservative)}

Only small patch of colour visible subdistally on inner face of merus of each cheliped. 


\section{Habitat}

Presumably deep-water inhabitant; collected at depth of $880 \mathrm{~m}$.

\section{Distribution}

Known only from the type locality off Cairns, Northern Territory.

\section{Entomology}

From the Latin crinitus meaning long-haired, and manus, a noun in apposition, meaning hand, and denoting the dense covering of long setae on the chelas of both chelipeds.

\begin{abstract}
Affinities
In having an unarmed telson, and just a single prominent row of spines or tubercles on the mesial face of the dactyls of each cheliped, $P$. crinitimanus, sp. nov. is most closely allied to $P$. jalur Morgan, 1992, and P. simplex Rahayu and McLaughlin, 2006. Nevertheless, in both of the latter species, the chelipeds are subequal, with either the right or left chela only slightly larger. In contrast, the chelas of $P$. crinitimanus, although generally similar in armature are not similar in size or shape. The left chela is vastly larger, subovate and with the breadth of the palm distinctly greater than that of the fixed finger and dactyl (Figure $7 \mathrm{~b}$ ). Additionally, the dorsolateral margin is not delimited, the surface being contiguous with the lateral face. The right (Figure $7 \mathrm{~d}$ ), however, is subrectangular, with the breadth of the palm only slightly greater than that of the combined breath of the fixed finger and dactyl; the dorsolateral margin is weakly delimited. Because $P$. crinitimanus presently is known from its unique, very large holotype, it is not possible to determine whether pronounced chela asymmetry is a function of growth as is seen in $P$. alcocki, but it is reasonable to assume that cheliped shape is not.
\end{abstract}

\section{Remarks}

The gonopod modified pleopods were not removed from the holotype, but the large size of the specimen made it possible to examine and illustrate these appendages. Of particular interest was the external lobe of superior lamella of pleopod 1. When fully extended, the terminal portion was of the typical triangular shape, although longer than seen in many species. However, in its in situ position, the terminal portion of the external lobe was curled around the appendix masculina of pleopod 2 as it lay in the deep cavity formed by the inferior lamella and internal lobe of pleopod 1.

\section{Paguristes triton sp. nov.} Figure 9

\section{Material examined}

\section{Holotype}

Western Australia. NTM (ovigerous female, 6.0 $\mathrm{mm}$ ), Soela stn NWS-7, Northwest Shelf (1833.2'S, $\left.117^{\circ} 30.9^{\prime} \mathrm{E}\right), 392-400 \mathrm{~m}, 25.04 .1982$.

\section{Paratypes}

Western Australia. NTM (1 male, $7.2 \mathrm{~mm}$ ), Soela stn NWS-7 (18 33.2'S, 117 30.9'E), 392-400 m, 25.04.1982; WAM C 14449 (1 male, $6.4 \mathrm{~mm}$ ), Courageous stn 29 (18 $\left.44^{\prime} \mathrm{S}, 116^{\circ} 59^{\prime} \mathrm{E}\right), 404-406 \mathrm{~m}$, 23.08.1983.

\section{Other material examined}

NTM (1 male, $8.2 \mathrm{~mm})$, Soela stn B2, (19 $56.8^{\prime} \mathrm{S}$, $\left.117^{\circ} 53.4^{\prime} \mathrm{E}\right), 42 \mathrm{~m}, 22.04 .1983$.

\section{Description}

Gills quadriserial; branchiostegites each with short row of very small spines or spinules on dorsal margin anteriorly and 2-4 more prominent spines on distal margin. Shield (Figure 9a) slightly longer than broad; anterolateral margins sloping; anterior margin between rostrum and lateral projections concave; posterior margin roundly truncate; lateral carapace lobes clearly delineated to partially fused to shield; dorsal surface usually with scattered small spines or spinules laterally and sparse setae. Rostrum triangular, usually over-reaching lateral projections and reaching to distal $0.3-0.5$ of ocular acicles; terminating acutely or subacutely. Lateral projections triangular, unarmed or each with small marginal spine.

Ocular peduncles usually subequal, left slightly longer; moderately stout, $0.6-0.7$ length of shield, dorsomesial surfaces each with row of sparse setae; corneal diameter $0.2-0.3$ of peduncular length. Ocular acicles triangular, each terminating in small spine; separated by $0.6-0.8$ basal width of 1 acicle.

Antennular peduncles, when fully extended, overreaching ocular peduncles by $0.2-0.6$ length of ultimate segment. Ultimate and penultimate segments unarmed; basal segment with ventromesial distal angle produced, terminating in slender spine; lateral face with prominent spine dorsally.

Antennal peduncles reaching from distal 0.1 of ocular peduncles to midlength of left of cornea; fifth segment unarmed; fourth segment with small spine at dorsodistal margin; third segment with ventromesial distal angle produced, terminating in prominent spine; second segment with dorsolateral distal angle produced, terminating in usually bifid spine, mesial and lateral margins unarmed; dorsomesial distal angle with small spine, mesial margin with few setae; first segment with ventromesial margin produced, with prominent distolateral spine. Antennal acicles reaching nearly 


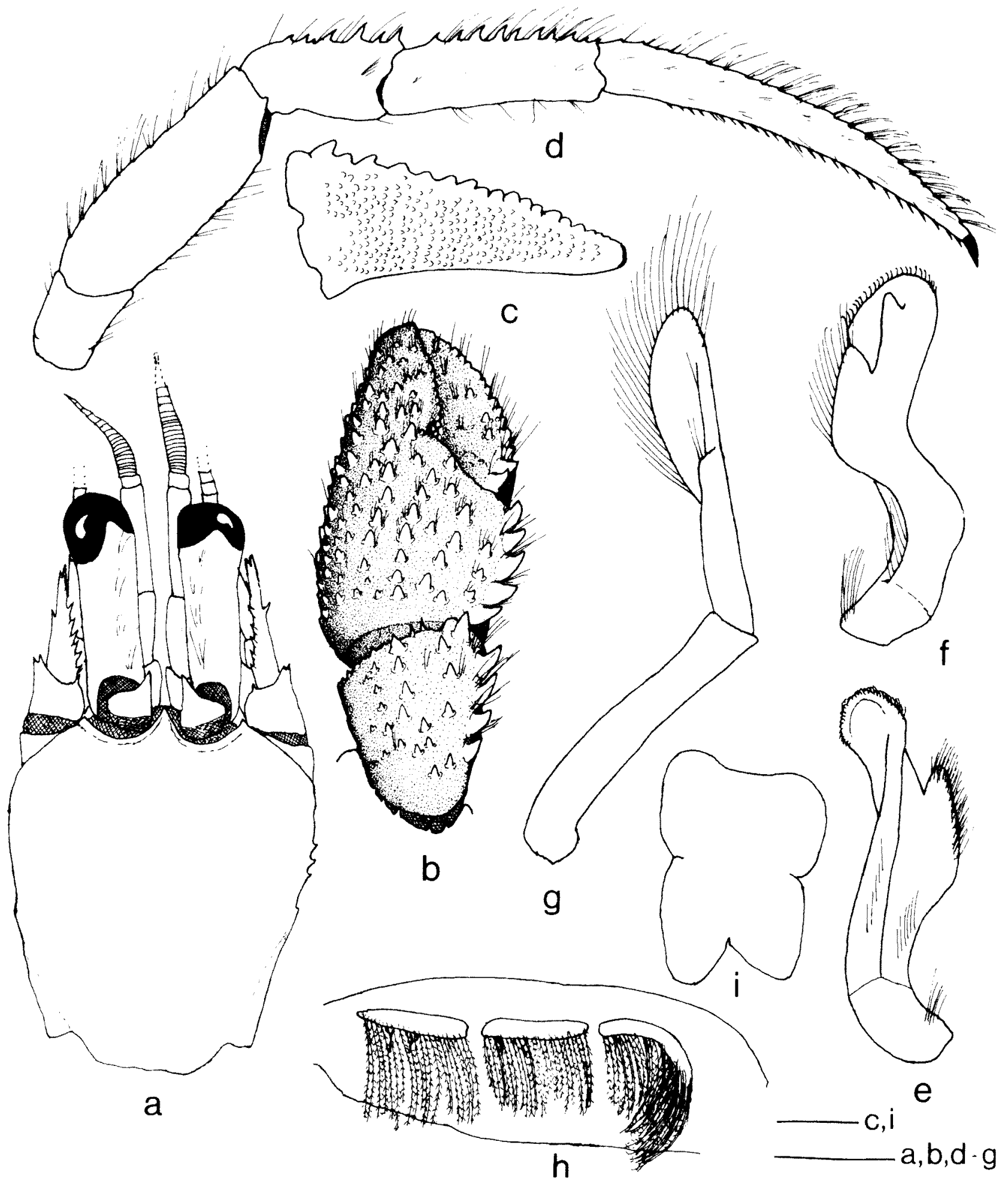

Figure 9 Paguristes triton sp. nov, a-d, $\mathbf{h}-\mathbf{i}$, holotype $(6.0 \mathrm{~mm})$, (NTM); e-g, paratype $(6.4 \mathrm{~mm})$, (WAM C 14449). a, shield and cephalic appendages (aesthetascs and most setae omitted); $\mathbf{b}$, chela and carpus of left cheliped (dorsal view); $\mathbf{c}$, dactyl of left chela (mesial view, setae omitted); $d$, right second pereopod (lateral view); $\mathbf{e}, \mathbf{f}$, male right first pleopod; $\mathrm{g}$, male right second pleopod; $\mathbf{h}$, pleon showing tergal thickenings of pleomeres $2-4$ and very small brood pouch developed as extension of tergite of pleomere $4 ; \mathrm{i}$, telson (setae omitted). Scales equal $2 \mathrm{~mm}(\mathrm{a}, \mathrm{b}, \mathrm{d}, \mathrm{h})$ and $1 \mathrm{~mm}(\mathrm{c}, \mathrm{e}-\mathrm{g}, \mathrm{i})$.

to or slightly beyond bases of comeas, each terminating in simple or bifid spine, mesial margins each with 4-7 moderately large spines usually over entire length; lateral margins unarmed or with 1 or 2 small spines distally. Antennal flagella equal to or longer than carapace; articles each with 24 short setae.

Third maxillipeds each with 1 small spine distally on ventral margin of ischium; merus with 3 acute spines on ventral margin and usually 1 tiny spinule 
on dorsodistal margin; carpus with or without dorsodistal spinule.

Chelipeds equal or left (Figure 9b) slightly larger, similar in armament. Dactyl 1.2-1.5 length of palm; cutting edge with 3-6 moderately small calcareous teeth in proximal $0.3-0.4$ and row of small corneous teeth in distal $0.7-0.6$, terminating in small corneous claw and slightly overlapped by fixed finger; dorsomesial margin with row of moderately small to moderately large, often corneous-tipped spines decreasing in size distally, and sparsely scattered setae; dorsal surface with irregular row of smaller spinulose tubercles mesiad of midline, occasionally 1 or 2 larger tubercles near articulation with palm; mesial surface (Figure 9c) with dense covering of very small, often corneous-tipped spinules or tubercles, and few tufts of very short setae distally; ventral surface with scattered tufts of stiff setae. Palm slightly shorter than carpus; dorsomesial margin with 4-6 prominent, often corneous-tipped, spines and few tufts of sparse setae; dorsal surface with 4 or 5 irregular rows of small to moderately large spines, $2-4$ rows extending onto fixed finger, dorsolateral margin not delimited, dorsal surface laterally and lateral surface with irregular rows of moderately small spines or spinulose tubercles, extending nearly to tip of fixed finger; mesial surface with few low protuberances; ventral surface with few, sometimes spinulose, protuberances and tufts of sparse setae; cutting edge of fixed finger with row of small calcareous teeth, terminating in small corneous claw; with or without slender proximal hiatus. Carpus 0.6-0.7 length of merus; dorsomesial margin with 4-6 spines, decreasing in size proximally, dorsal surface with few small spines or tubercles in distal half and 1 or 2 irregular rows of smaller spines and few short setae mesiad of relatively unarmed midline, dorsolateral margin not distinctly delimited but with irregular row of small spines or tubercles, lateral face with scattered small spines or spinules, ventrolateral distal angle produced, with terminal spine or spinule; mesial surface with very few low protuberances; ventral surface unarmed. Merus with 1 to several spines on distal margin, largest dorsally, dorsal surface with row of short, transverse, spinose ridges; mesiodistal margin with few tubercles or spinules, surface unarmed, ventromesial margin with row of small spines or spinulose tubercles; lateral surface with numerous short, spinose, spinulose and/or denticulate ridges, ventrolateral margin with numerous tiny tubercles or spinules; ventral face with few tiny tubercles. Ischium usually with row of minute tubercles on ventromesial margin. Coxa unarmed or with small spine on each ventromesial and ventrodistal margin.

Second (Figure 9d) and third pereopods generally similar. Dactyls long, 1.4-1.8 times length of propodi; in lateral view curved ventrally, in dorsal view relatively straight; terminating in moderately small, corneous claws; dorsal surfaces of second pereopods each with row of tufts of long, stiff setae, and short row of several moderately small, often corneous-tipped spines in proximal 0.3 , third each with low, occasionally spinulose, protuberances proximally and row of tufts of long, stiff setae; mesial surfaces each with row of tufts of stiff setae in dorsal half and ventral row of sparse, finer setae; lateral surfaces each with row of sparse setae; ventral margins each with row of 28-36 corneous spines. Propodi of second pereopods each with row of prominent, usually corneous-tipped spines and scattered short to moderately long setae on dorsal surface, third with spines replaced by spinulose protuberances; mesial surfaces each with 1 or 2 rows of tufts of sparse setae; lateral surfaces each with median row of sparse tufts of setae; ventral surfaces each with row of spinulose protuberances or small spines and tufts of setae. Carpi of second pereopods each with row of moderately large spines and tufts of sparse long setae on dorsal surface, third each with dorsodistal spine and 2-4 smaller spines in proximal 0.5 ; mesial surfaces with few tufts of short setae; lateral faces each with tufts of stiff setae on midline and longitudinal sulcus sparsely lined with setae; ventral surfaces each with tuft of setae distally. Meri each with low protuberance on dorsal surface distally, often becoming spinulose or spinose proximally; mesial and lateral faces unarmed; ventral margins of second pereopods each with row of small spines or spinules and sparse short setae, third with only setae. Ischia unarmed or with few spinules on dorsal and ventromesial margins. Coxae unarmed or with 1 or 2 small spines on ventral margins. Fourth pereopods each with small preungual process at base of claw. Propodal rasp composed of 2-4 rows of corneous scales. Carpus without dorsodistal spine.

Male first pleopod (Figure 9e, f) with tuft of long setae on mesiodistal angle of basal segment. Inferior lamella with thickened and weakly calcified lateral margin, few setae proximally; distal margin broadly rounded and similarly thickened, but not calcified, armed with row of prominent, outwardly curved, corneous spines; external lobe moderately narrow, terminating subacutely and not reaching distal margin of inferior lamella; internal lobe moderately small, subovate, mesial margin with row of long setae. Second pleopod (Figure 9g) with glabrous basal segment; distal segment with endopod slightly twisted, row of setae on inner margin and extending onto outer margin distally; appendix masculina with 1 or 2 terminal setae. Third to fifth unpaired pleopods with exopods very well developed, endopods vestigial.

Females with articulation between basal and distal segments of paired first pleopods distinct. 
Second to fourth unpaired left pleopods with both rami well developed, exopods much longer than endopods; fifth with exopod well developed, endopod rudimentary. Brood pouch (Figure 9h) developed only as narrowly subtriangular flap of tissue with marginal, dense, long, plumose setae. Second to fourth pleonal tergites each with area of weak calcification on both left and right margins, left each with row of moderately dense, long setae partially obscuring bases of pleopods, right with long setae only on tergite 2 .

Telson (Figure 9i) with posterior lobes nearly symmetrical to very asymmetrical, separated by moderately small median cleft, each lobe subtriangular with apex rounded, terminal and lateral margins unarmed but with long setae; lateral indentations distinct; anterior lobes unarmed.

\section{Colouration}

Not known.

\section{Habitat}

Unknown

\section{Distribution}

Known only from northwestern Australia; 42$404 \mathrm{~m}$.

\section{Etymology}

A noun in apposition, after the mythological Greek sea-god Triton who used a conch shell to control the waves.

\section{Affinities}

Paguristes triton, sp. nov., appears morphologically most similar to two Indian species, P. calvus Alcock, 1905 and P. mundus Alcock, 1905, in lacking appreciable setation on the chelipeds. Alcock's (1905) descriptions of both taxa were brief and lacking in many specifics; however, P. mundus is depicted by Alcock (1905: pl. 3, fig. 5) as having broad and multifid ocular acicles, although no mention of the acicles is made in his description of the species. The ocular acicles of $P$. triton are slender and each has only a single terminal spine.

Rahayu and McLaughlin (2006) have provided a detailed supplemental description and illustrations of $P$. calvus that show conclusively that $P$. triton and $P$. calvus are not conspecific. Most significant are the differences in armature of the mesial faces of the dactyls of the chelipeds in the two species. These surfaces in $P$. calvus each has a primary median longitudinal row of corneous-tipped small spines and a few more scattered spines and spinules ventrally. In contrast, these surfaces in $P$. triton have a covering of tiny spinules or tubercles that form numerous irregular vertical rows.

\section{Remarks}

Komai (2001), in his description of Paguristes versus Komai, 2001, remarked on the fine, long setae on the second to fifth left pleonal somites that he believed had been reported previously only in $P$. lauriei McLaughlin and Hogarth, 1998; however, the latter species was said to lack a brood pouch. A brood pouch is present in the ovigerous female holotype of $P$. triton, sp. nov., but it is extremely slender and is little more that a narrow flap of tissue from which very long dense setae arise on either side. Like the female of $P$. lauriei, the eggs of the second and third left pleopods are protected by a fringe of dense setae arising from thickenings in the pleonal wall above the acetabula of these appendages. A similar thickening above the acetabulum of the fourth pleopod, also provided with dense setae, is continued somewhat ventrally as the flap of tissue constituting the brood pouch that effectively conceals, albeit does not enclose, the eggs attached to the fourth pleopod. The holotype and only specimen known of $P$. lauriei was damaged and the posterior portion of the pleon, uropods and telson were missing. However, there is no doubt that despite the similarities of incubation characters, the two species are distinct. An immediate distinguishing character is the armament of the mesial faces of the dactyls of the chelipeds, or lack there of. In P. triton these surfaces are covered by very closely-packed minute tubercles. In $P$. lauriei, these surfaces are unarmed (C.H.J.M. Fransen, personal communication)

\section{Paguristes palythophilus Ortmann, 1892 Figure 10}

Paguristes palythophilus Ortmann, 1892: 277, pl. 12, fig. 5, 5p, 5q. - Doflein, 1902: 645. - Alcock, 1905: 155 (literature). - Balss, 1913: 38. - Balss, 1924: 768. - Balss, 1926-27: 968. - Gordan, 1956: 323 (in part) (literature). - Miyake, 1978: 32 (in part), not fig. 10. - Miyake and Imafuku, 1980a: 3 (in part). - Yu and Foo, 1991: 51, unnumbered fig. Komai, 2001: 359, figs 3-6 (see Remarks).

? Paguristes palithphilus. - Yokoya, 1933: 73 (misspelling).

Paguristes palythophilus. - Terao, 1913: 374. Mivake, 1961: 11. - Miyake et al., 1962: 125 (list).

Paguristes kagoshimensis. - Miyake, 1978: 35 (in part).

Not Paguristes palythophilus. - Mivake, 1982: 96, pl. 32, fig. 4. - Takeda, 1982: 58, fig. 174 (= Paguristes albimaculatus Komai, 2001).

\section{Lectotype}

MZS (male, $11.2 \mathrm{~mm}$ ), Sagami Bay, $126-180 \mathrm{~m}$, coll. L. Doderlein, 1881 (not seen). 


\section{Material examined}

Western Australia. WAM C 16513 (1 male, 5.5 $\mathrm{mm} ; 1$ ovig. female, $5.6 \mathrm{~mm}$ ), Soela stn 01/84/055, WNW of Lacepede Arch (15 57.2'S, $\left.120^{\circ} 46.2^{\prime} \mathrm{E}\right)$, 296-298 m, 10.02.1984; WAM C29555 (ex WAM C 16282) (2 males, 2.9, $6.0 \mathrm{~mm}$; female, $3.8 \mathrm{~mm}$ ), 104 n. mls $\mathrm{N}$ of Pt. Hedland (18 41'S, $\left.118^{\circ} 58^{\prime} \mathrm{E}\right), 150 \mathrm{~m}$, 28.03.1982; WAM C 16480 (8 males, $2.4-6.5 \mathrm{~mm}$; 1 ovig. female, $4.5 \mathrm{~mm}), 114 \mathrm{n}$. mls off Port Hedland (1825'S, $\left.118^{\circ} 22^{\prime} \mathrm{E}\right), 201 \mathrm{~m}, 02.04 .1982$; WAM C 16811 (1 male, $5.8 \mathrm{~mm}$ ), North West C., near the wreck of Mildura, WAM group station 15 , 02.06.1986; WAM C 29557 (ex WAM C 16720) (1 male, $4.8 \mathrm{~mm}$ ), NW of C. Leveque, Soela stn S01/84/ 084, 200-236 m, 16.02.1984; WAM C 16721 (1 male, $3.5 \mathrm{~mm})$, Soela stn S01/84/086, NNW of Cape Leveque, 252-260 m, 17.02.1986.

\section{Abbreviated description}

Gills quadriserial; branchiostegites each with row of small spines on anterodorsal and distal margins. Shield (Figure 10a) longer than broad; dorsal surface with small spines or spinules and scattered tufts of setae laterally. Rostrum triangular or subtriangular, distinctly overreaching lateral projections, reaching from bases to distal $0.3-0.5$ of ocular acicles; terminating acutely, bluntly or with small spine. Lateral projections obtusely triangular, usually with small marginal spine. Ocular peduncles 0.6-0.7 length of shield; each with longitudinal row of sparse tufts of setae on dorsal or dorsomesial surface; corneal diameter $0.2-0.3$ of peduncular length. Ocular acicles each with acute terminal spine. Antennular peduncles, when fully extended, reaching distal corneal margins or exceeding margins by $0.3-0.5$ length of ultimate segment. Antennal peduncles reaching distal 0.3 of ocular peduncles to slightly beyond bases of corneas; second segment with dorsolateral distal angle weakly to prominently produced, terminating in simple or bifid spine, dorsomesial distal angle with prominent spine. Antennal acicles reaching from proximal 0.5 to nearly distal margins of fifth peduncular segments, each terminating in simple or bifid spine, with long setae; mesial margin with 3-6 moderately prominent spines in proximal $0.5-0.7$; lateral margin with $0-3$ spines. Antennal flagella slightly shorter to considerably longer than carapace, with sparse to moderately numerous long and short setae every $1-4$ articles.

Chelipeds moderately short, equal or slightly subequal, with left (Figure 10b) slightly larger; similarly armed. Dactyl with $2-4$ moderate to very prominent calcareous teeth in proximal half of cutting edge and row of small corneous teeth distally, terminating in small corneous claw; slightly overlapped by fixed finger; dorsomesial margin with row of small to moderately large, sometimes corneous-tipped spines decreasing in size distally, and tufts of stiff setae; dorsal surface with single or double row of moderately small spines near dorsomesial margin and few small tubercles proximally; mesial face (Figure 10c) with 3-5 irregular rows of small to moderate, frequently corneous-tipped spines and/or spinules. Palm with 4-6 prominent, occasionally corneous-tipped spines and tufts of long stiff setae on dorsomesial margin; dorsal surface with several irregular rows of small to moderately large spines or tubercles, extending onto fixed finger, accompanied by sparse tufts of moderate to long setae, dorsolateral margin not delimited; mesial and lateral faces with scattered protuberances and/or small spines accompanied by tufts of setae; cutting edge of fixed finger with row of small calcareous teeth, terminating in small corneous claw; with slender hiatus proximally. Carpus with row of 4-7 spines on dorsomesial margin, dorsal surface with tufts of stiff setae and small spines or spinulose tubercles most numerous in distal half, dorsodistal margin often with row of small spines; dorsolateral margin with row of small spines or tubercles. Merus with row of small spines or spinulose tubercles on ventromesial margin; ventrolateral margin usually unarmed or with few small spines or spinulose protuberances.

Second and third pereopods (Figure 10d) moderately long and slender. Dactyls 1.5-1.9 longer than propodi; dorsal surfaces each with row of tufts of long stiff setae and 1 to short row of several moderately small, often corneous-tipped spines in proximal 0.3 (second) or only low protuberances and numerous tufts of long setae (third); mesial faces and lateral surfaces each with 1-3 rows of tufts of setae, or sometimes simply scattered; ventral margins each with row of 19-29 slender corneous spines. Propodi each with row of moderately prominent spines on dorsal surface (second), low protuberances or unarmed (third) and tufts of long setae; mesial and lateral surfaces each with $1-3$ rows of tufts of short to long setae. Carpi each with single or double row of moderately prominent spines (second) or dorsodistal spine and occasionally 1 to few additional spinules (third) and tufts of long setae on dorsal surface. Meri of second pereopods each with ventromesial and ventrolateral marginal row of small spinules, at least in distal half, and sparse short setae; third pereopods each with low protuberances and tufts of moderate to long setae dorsally and ventrally. Fourth pereopods (Figure $10 \mathrm{e}$ ) each with small preungual process at base of claw.

Male first pleopod (Figure 10f, g) with short setae on lateral margin of inferior lamella, 1 row of hook-like spines on distal margin; external lobe not overreaching distal margin of inferior lamella; internal lobe with long marginal setae and shorter setae on inner surface. Second pleopod (Figure 10h) with basal segment naked; 


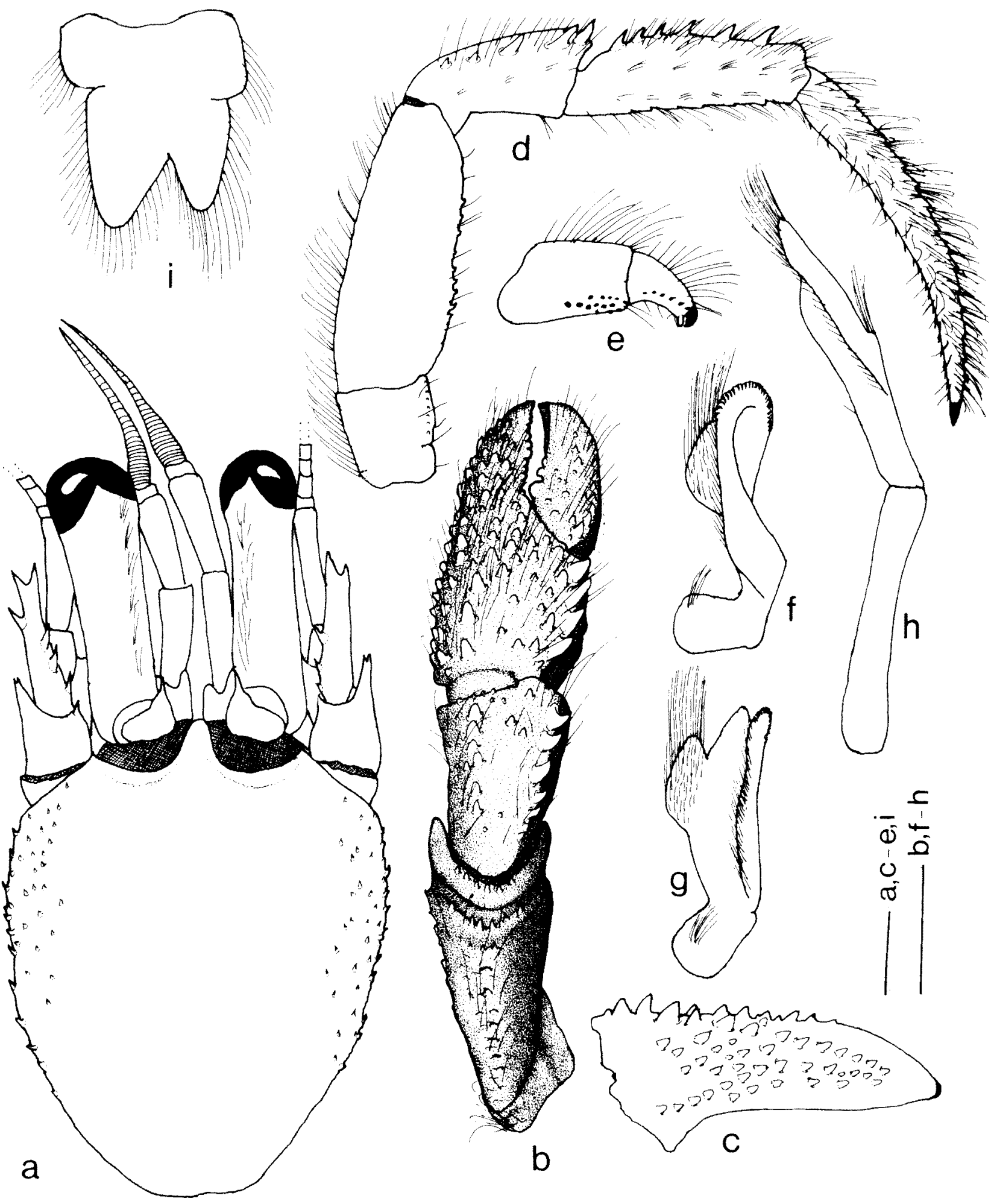

Figure 10 Paguristes palythophilus Ortmann, 1892, a, b, d, e, i, male (5.5 mm) (WAM C 16513); $\mathbf{c}, \mathbf{f}-\mathbf{h}, \mathrm{male}(6.0) \mathrm{mm}$ ) (WAM C 16282). a, shield and cephalic appendages (aesthetascs and some setae omitted); $b$, left cheliped (dorsal view); c, dactyl of left chela (mesial view, setae omitted); d, left second pereopod (mesial view); e, dactyl and propodus of right fourth pereopod (lateral view); $f$, male left first pleopod; $h$, left second pleopod (internal view); $i$ telson. Scales equal $2 \mathrm{~mm}$ (b) and $1 \mathrm{~mm}(\mathrm{a}, \mathrm{c}-\mathrm{i})$.

distal segment with tuft of setal distally on endopod, appendix masculina with long distal setae and shorter marginal setae. Female brood pouch ovately triangular, with marginal plumose setae; left pleonal tergites $2-4$ with marginal thickenings and dense fringe of long, plumose setae.

Telson (Figure 10i) with posterior lobes weakly asymmetrical, left lobe slightly larger; each subtriangular with rounded apex, separated by 
shallow median cleft, terminal and lateral margins unarmed but with long setae.

\section{Colour (in life)}

"Entire animal orange red generally; spines, tubercles, protuberances on chelipeds and ambulatory pereopods showing as white spots. Ocular peduncles with two white longitudinal stripes dorsolaterally and mesially, dorsal surface between two white stripes generally orange, becoming darker mesially, with longitudinal row of white spots; lateral and ventral faces deep red. Antennular peduncles orange, flagellum white. Antennal flagellum generally paler proximally" (Komai, 2001).

In preservative, the Australian specimens have lost most of their colour; however, in some of the specimens each ocular peduncle retains an orange colouration ventrally and a faint to moderately prominent longitudinal orange stripe is still discernable dorsally.

\section{Habitat}

Gastropod shells, often encrusted with Epizoanthus species (Komai, 2001).

\section{Distribution}

Sagami and Tosa Bays, off Boso Peninsula, Japan, southwestern Taiwan; northern Western Australia; 80-298 m.

\section{Affinities}

The Australian specimens attributed to $P$. palythophilus are morphologically very similar, not only to the Japanese population of $P$. palythophilus, but also to $P$. albimaculatus Komai, 2001. Were it not for the colour differences reported by Komai for the Japanese taxa, the variability described for the Australian material would cause concern about the distinctiveness of the two Japanese species. The residual colour of the ocular peduncles (i.e., a dorsal orange stripe bounded dorsomesially and dorsolaterally by stripes of white) of the Australian specimens indicates that they should be assigned to $P$. palythophilus. Komai distinguished $P$. palythophilus from $P$. albimaculatus morphologically by differences in the length of the ultimate segments of antennular peduncles, number of spines on the ventral margins of the ambulatory dactyls (25-44 opposed to 15-20); the mesial faces of the dactyls of the cheliped with more numerous spinules in $P$. palythophilus and the more slender and prominently produced male rostrum of that species. As may be seen from the variations reported by McLaughlin (2004b) in her study of intraspecific variation in $P$. puniceus, few of these attributes are reliable diagnostic characters. Komai (2001) considered the armature of the mesial face of the dactyl of the left cheliped a dependable means for separating $P$. palythophilus from $P$. albimaculatus. The spinules on this surface in $P$. palythophilus were described as numerous and scattered, but fewer and stronger in $P$. albimaculatus, with the ventral spines forming a distinct row. The mesial face of the dactyl of the left chela of a male $(\mathrm{sl}=5.5 \mathrm{~mm})$ of $P$. palythophilus from WNW of Lacepede Archipelago has several irregular rows of small spines, with the ventral spines forming a quasi distinct row, whereas that surface in the male ( $\mathrm{sl}=6.0 \mathrm{~mm}$ ) from Soela station 01/84/055 off Point Hedland (Figure 10c) has fewer and larger spines, forming only a quasi ventral row. However, there are other specimens from the same station in which the spines do form a distinct ventral row, but the dorsal stripes of color are still visible on the ocular peduncles.

\section{Remarks}

In his synonymy of $P$. palythophilus, Komai (2001) indicated that Miyake's (1978) figures were not of this species. However, Komai (2001: 359) inadvertently cited the figures as 31 and 32 . Miyake's (1978) figures 31 and 32 are of Pagurus conformis (De Haan, 1849) fas Pagurus megalops (Stimpson, 1858), cf. Komai (2004)] and $P$. constans (Stimpson, 1858), respectively. Miyake's (1978) figure 10 represented Paguristes palythophilus, an illustration that Komai (2001: 369) attributed to $P$. albimaculatus. Also in his synonymy, Komai indicated that Terao's (1913) report of $P$. palythophilus was not of that species. However, in his discussion, Komai (2001: 369) stated that he had not been able to locate Terao's (1913) specimens; therefore, it was not possible to decide what species Terao might have had. Terao's report is included questionably in the present synonymy.

As previously indicated, Komai (2001: 415, fig. 27) described and illustrated the setation of the female abdomen of $P$. versus as a "condition similar to that known only in P. lauriei McLaughlin and Hogarth, 1998 ..." Nevertheless, a similar dense setation was also described by Komai (2001) for both $P$. palythophilus and $P$. albimaculatus. The Australian females of $P$. palythophilus have similar pleonal setation. The presence of $P$. palythophilus represents a considerable extension of the range of this species, although there are unpublished records of its occurrence in New Caledonia. No shells remained with the Australian specimens, thus it was not possible to verify the habitual association of this species with shells encrusted by epizoanthids.

\section{Paguristes jalur Morgan, 1992} Figure 11

Paguristes jalur Morgan, 1992: 167, figs 1, 2. - Davie, 2002: 55. - Osawa and Takeda, 2004: 1099, figs 1-4. 


\section{Holotype}

Indian Ocean, Cocos (Keeling) Islands. WAM C 19580 (male, $4.8 \mathrm{~mm}$ ), Horsburgh I., Cocos (Keeling) Is, to $37 \mathrm{~m}$ (not seen).

\section{Material examined}

Christmas Island. WAM C 24143 (1 female, 2.3 $\mathrm{mm}$ ), stn 3, Ethel Beach, 5-24 m, coll. G. J. Morgan, 20.02.1987. Guam. FMNH (1 female, $3.8 \mathrm{~mm}$ ), Orote forereef, 9-25 m, coll. G. Paulay, 09.11.1999; FMNH (1 female, $3.6 \mathrm{~mm}$ ), Orote forereef, $14.6 \mathrm{~m}$, under rocks, 09.03.2000; FMNH (1 juv. male $2.0 \mathrm{~mm}$ ), Agat Bay, Alutom I., 3-8 m, coll. H.T. Conley, 06-07.2000.

\section{Abbreviated description}

Gills biserial or distally quadriserial; branchiostegites each with row of large spines on dorsal margin. Shield (Figure 11a) longer than broad; dorsolateral surfaces with scattered small spines, often 1 or 2 larger spines centrally on lateral margin; scattered long plumose setae. Rostrum long, moderately slender, considerably exceeding lateral projections, with terminal spinule. Lateral projections broadly triangular, each with apical spinule or spine. Ocular peduncles (Figure 11a, b) slender in adults, but moderately stout in juvenile, 0.6-0.9 length of shield; inflated basally; dorsal
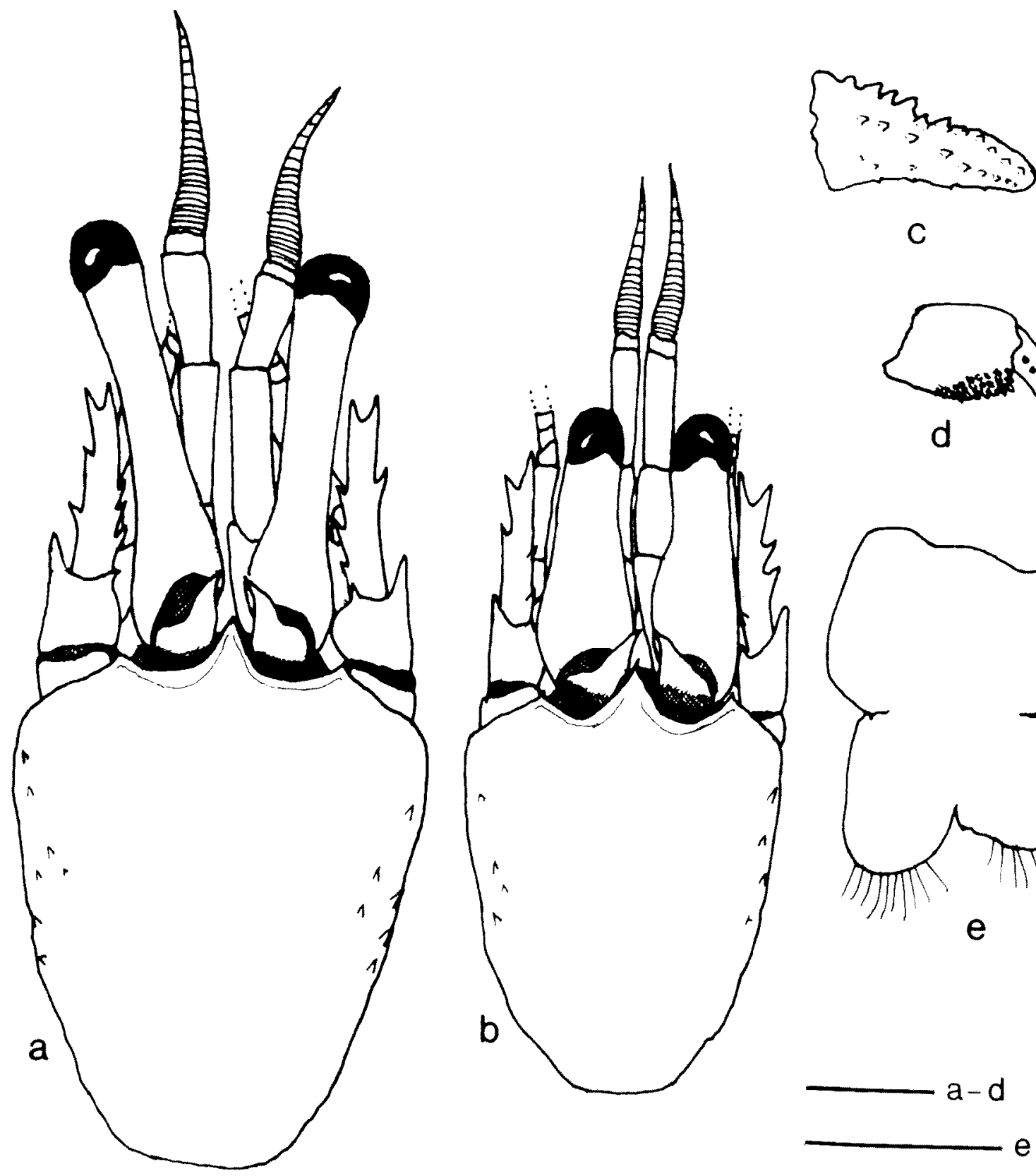

C

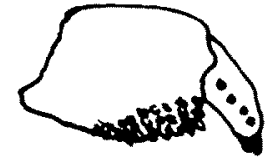

d

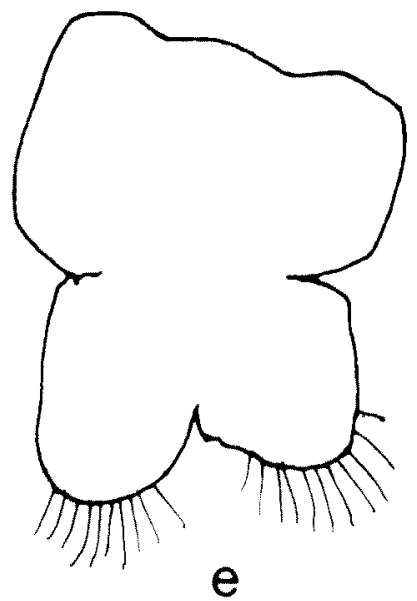

$a-d$

Figure 11 Paguristes jalur Morgan, 1992, a, c, d, e, female $(3.8 \mathrm{~mm})$ (FNHM); b, male (2.0 mm) (FNHM). a, b, shield and cephalic appendages (aesthetascs and setae omitted); c, dactyl of left chela (mesial view, setae omitted); d, propodus and dactyl of right fourth pereopod (lateral view, setae omitted); e, telson. Scales equal $1 \mathrm{~mm}$. 
surface with few long setae proximally; corneal diameter slightly more than 0.1 to nearly 0.2 of peduncular length; ocular acicles narrowly triangular with mesial margins slightly sinuous or weakly concave; with prominent terminal spine. Antennular peduncles overreaching distal corneal margins by entire length of ultimate segments in juvenile, but reaching only from corneal bases to distal corneal margins in adults. Antennal peduncles reaching to midlength of corneas in juvenile, but only $0.5-0.7$ of ocular peduncles in adults; second segment with dorsolateral distal angle produced, terminating in bifid spine, dorsomesial distal angle usually with small spine; first segment unarmed or with 1 or 2 spines on ventrolateral margin. Antennal acicles reaching beyond proximal half of ultimate peduncular segment in adults and to distal 0.2 in juvenile, terminating in prominent bifid spine; lateral margin with 2 or 3 spines, mesial margin with 2 or 3 spines in proximal half. All segments and acicles with sparse, long, lightly plumose setae. Antennal flagella overreaching chelipeds and longer than carapace in adults, but not quite as long as carapace in juvenile.

Chelipeds subequal or right slightly larger; similar in shape and armament. Dactyl with row of acute spines on dorsomesial margin, row of small tubercles on dorsal surface; cutting edge with calcareous teeth proximally, corneous teeth for distal 0.3 ; terminating in blunt corneous claw; mesial face (Figure 11c) and ventromesial margin each with row of small spines; surfaces with scattered tufts of simple setae, most numerous mesially. Palm with row of 4 or 5 large spines on dorsomesial margin and often 2 or 3 on adjacent mesial face, dorsal surface with irregular rows of spines and tufts of setae, 1 row extending onto fixed finger mesiad of midline, dorsolateral margin with row of prominent spines decreasing in size distally; dorsal surface of fixed finger with scattered smaller spines; cutting edge with row of calcareous teeth, slender hiatus proximally between dactyl and fixed finger. Carpus with 4 or 5 large conical spines on dorsomesial margin; dorsal surface with irregular longitudinal rows of spines and numerous tufts of short plumose setae; dorsolateral margin with row of moderately large spines extending nearly to tip of fixed finger. Carpus with 4-6 prominent spines on dorsomesial margin, largest distally; dorsal surface with median row of smaller spines; dorsolateral margin with row of moderately large spines; few additional scattered spines or tubercles and tufts of moderate to long plumes setae. Merus with armature of dorsal margin varying from row of crenulations and small spines to row of quite prominent spines, decreasing in size proximally; ventrolateral and ventromesial margins each with row of spines; scattered setae especially on dorsal and ventral margins.

Second and third pereopods with dactyls longer than propodi; dorsal surfaces each with row of small spines; mesial faces each with shallow sulcus, at least proximally, and flanked ventrally by row of minute corneous spinules; ventral margins each with row of 9-12 corneous spines. Propodi each with row of prominent spines on dorsal margin on second pereopods, row of smaller spines or occasionally with only 1 or 2 small spines distally on third; 1 or more spinules on each ventrodistal margin and usually row of spinules or small spines on ventral margin. Carpi of second pereopods each row of spines on dorsal margin; carpi of third with smaller row of spines or only with dorsodistal spine. Meri with dorsal margins unarmed or with row of spinules or spinulose protuberances; distolateral angles each with or without small spine; ventral margins of second pereopods each with row of small spines, third with low, sometimes spinulose protuberances. All segments with long but not necessarily dense setae, particularly on dorsal and ventral margins, occasionally absent. Fourth pereopods (Figure 11d) each with preungual process at base of claw; propodal rasp with multiple rows of small corneous scales.

Male first pleopods each with row of hook-like spines on inferior lamella; external lobe slightly overreaching distal margin of inferior lamella; internal lobe short, with marginal long setae. Second pleopods each with naked basal segment, endopod with few short setae; appendix masculina with marginal long setae (based on Morgan, 1992, figs $1 \mathrm{C}-\mathrm{E}$ and Osawa and Takeda, figs $4 \mathrm{~A}-\mathrm{G}$ ). Female brood pouch subquadrate, distal margin scalloped or not and fringed with setae.

Telson (Figure 11e) with left posterior lobe somewhat larger than right; separated by broad median cleft; terminal margins unarmed but with long setae.

\section{Colour (in life)}

"Shield and posterior carapace cream or white. Ocular peduncles and acicles white; corneas black. Antennular peduncles white, flagella often tinged with pink. Antennal peduncles white, ultimate segment sometimes with maroon tinge; flagella clear proximally, becoming more maroon distally. Chelipeds cream or pale orange with deep maroon longitudinal stripes. Dactyl with broad mesial and dorsal maroon stripes; thinner lines dorsally and ventrally near cutting edge. Propodus with broad median dorsal stripe along finger and onto palm; thin line dorsally near cutting edge; broad extension of stripe from dactyl posteriorly on palm, this sometimes reticulating with more lateral stripe on palm; broad stripes mesially, 
ventrolaterally and irregular band ventrally on palm. Carpus with 2 dorsal stripes and 1 lateral stripe, most of mesial surface maroon. Merus with broad irregular maroon annulus subdistally, often smaller maroon patches proximally. Cheliped spines usually cream. Second and third pereopods cream or pale orange striped with maroon; dactyl, propodus and carpus with dorsolateral, ventrolateral, dorsomesial and ventromesial maroon stripes; merus with broad maroon annulus subdistally and small patches proximally" (Morgan, 1992).

\section{Habitat}

Coral reefs; subtidal.

\section{Distribution}

Cocos (Keeling) and Christmas Islands, Japanese Ryukyu Islands, Guam; 2-37 m.

\section{Affinities}

Morgan (1992) and Osawa and Takeda (2004) related $P$. jalur to $P$. runyanae Haig and Ball, 1988 , because both species shared the presumably diagnostic characters of antennal flagella longer than the carapace, ocular peduncles longer than the antennular peduncles and posterior lobes of the telson unarmed; however the latter authors also included P. acanthomerus Ortmann, 1892 and $P$. alegrias Morgan, 1987, as species sharing those same characters. Although the unarmed telson certainly is indicative of affinity, it is a character that both species share with several Australian and Japanese species. Judging from Haig and Ball's (1988: 174, fig. 6D) description and figure, $P$. jalur and $P$. runyanae share an additional character, the presence of a single prominent row of spines or tubercles on the mesial faces of the dactyls of the chelas, a character not considered by Morgan (1992) or Osawa and Takeda (2004). Despite some observed variability, the armature of the mesial faces of these dactyls can be an important aid in species recognition. Similarly, although growth related variation in ocular peduncle length cannot be ignored, the ocular peduncles of $P$. runyanae are considerably longer for animals of comparable sizes. Nevertheless, colour and colour patterns appear to be the most reliable distinguishing characters between $P$. jalur and $P$. runyanae.

The gills of the Guam specimens of $P$. jalur are distally quadriserial, whereas Osawa and Takeda (2004) described the gills of their much larger specimens from the Ryukus Islands as biserial. The gill morphology of $P$. jalur is important in distinguished Morgan's (1992) species from the similar $P$. simplex Rahayu and McLaughlin, a species in which the gill lamellae are deeply quadriserial.
Additional characters that will separate $P$. jalur from $P$. simplex are the large spines on the dorsal margins of the branchiostegites, the development, at least in larger specimens, of longitudinal sulcuslike depressions on the dactyls and fixed fingers of the chelas, the propodal rasp of the fourth pereopod that is provided with multiple rows of corneous scales, and the shape of the female brood pouch of the former species.

\section{Remarks}

The female from Christmas Island (WAM C 24143) appears to be the specimen reported as lost by Morgan (1992: 167). Although the holotype of Paguristes jalur was not examined, this species has such a distinctive colour pattern that its identification among the materials from Guam was unmistakable. The two adult females from Guam agree quite well with Morgan's (1992) description of the holotype and paratypes from the Cocos (Keeling) Islands. The male $(2.0 \mathrm{~mm})$ clearly is a juvenile as the paired first pleopods are simply small buds; there is no indication of development yet of the second pleopods. The gonopores, although apparent, are quite small. However, in the relationships of shield length to ocular peduncle length, antennular and antennal peduncular lengths, and antennal flagellar length, the influence of animal size is evident. As indicated in the diagnosis, the ocular peduncles of the small male are appreciably shorter and stouter than those of the adults, whereas the antennular and antennal peduncles are longer. However, the juvenile antennal flagella are shorter than those of the adults.

Osawa and Takeda (2004) profusely illustrated the largest male $(6.7 \mathrm{~mm})$ in their collection. That specimen, at least, has a pronounced longitudinal sulcus-like depression on the dorsal surface of both the dactyl and the fixed finger of the right cheliped, and the authors commented that similar sulci were evident on the chela of the right cheliped illustrated by Morgan (1992, fig. 2A), although no such depressions were mentioned by Morgan in his description. These sulci are not developed in the Guam specimens; however, the surface areas between the rows of spines on both the dactyls and fixed finger of the chelas are smooth and marked by a longitudinal stripe of color. It would appear that these sulci develop in conjunction with increases in animal size. A similar size related variation is apparent in the armament of the ventral margins of the pereopodal dactyls. Morgan (1992) did not specifically give a number but illustrated the left second and third pereopods as having 12 or fewer; $9-12$ were present in the Guam specimens. In contrast, Osawa and Takeda (2004) reported 11-20 spines on these margins. 
Paguristes simplex Rahayu and McLaughlin, 2006 Figure 12

\section{Material examined}

\section{Holotype}

Madagscar. MNHN Pg (male, $6.0 \mathrm{~mm}$ ), Vauban stn. $14\left(12^{\circ} 43.3^{\prime} \mathrm{S}, 48^{\circ} 15.7^{\prime} \mathrm{E}\right), 245-255 \mathrm{~m}$, coll. A. Crosnier, 15.04.1971.

\section{Paratypes \\ Madagascar. MNHN Pg (3 males, $5.8-6.0 \mathrm{~mm}$ ), Vauban Stn. $14\left(12^{\circ} 43.3^{\prime} \mathrm{S}, 48^{\circ} 15.7^{\prime} \mathrm{E}\right), 245-255 \mathrm{~m}$, coll. A. Crosnier, 15.04.1971. Western Australia. WAM C 16301 (3 males, 5.8-7.4 mm; 2 females, 4.5 . $4.7 \mathrm{~mm}$; 1 ovig. female, $5.3 \mathrm{~mm}$ ) and WAM C 163715 ( 2 males, both $4.6 \mathrm{~mm} ; 3$ females, 2.9. 3.8 $\mathrm{mm} ; 1$ ovig. female, $4.1 \mathrm{~mm}$ ), $114 \mathrm{n}$. mls $\mathrm{N}$ of Point Hedland (18 $\left.25^{\circ} \mathrm{S}, 118^{\circ} 22^{\prime} \mathrm{E}\right), 201 \mathrm{~m}, 02.04 .1982$.}

\section{Abbreviated description}

Gills deeply quadriserial; branchiostegites each with short row of very small to tiny spinules on dorsal margin distally. Shield (Figure 12a) slightly longer than broad; dorsal surface very few spinules marginally and very sparse setae. Lateral projections triangular, subacute, with or without terminal spinule. Rostrum triangular, reaching beyond bases of ocular acicles, unarmed or with terminal spinule and with marginal short setae. Ocular peduncles unequal, left longest, $0.6-0.8$ length of shield; dorsal surfaces each with sparse row of moderately long setae; corneal diameter $0.1-0.3$ peduncular length. Ocular acicles acutely triangular, each with small terminal spine. Antennular peduncles not quite reaching left distal corneal margin to exceeding margin by 0.3 length of ultimate segment. Basal segment with acute spine on dorsolateral margin of statocyst lobe and 1 spine at ventromesial distal angle. Antennal peduncles reaching distal $0.2-0.3$ of left ocular peduncle; fourth segment with small dorsodistal spine; third segment with prominent ventrodistal spine; second segment with dorsolateral distal angle produced, terminating in simple or bifid spine; dorsomesial distal angle with small to moderately large spine; first segment with small spine on ventrodistal margin. Antennal acicle reaching $0.5-0.6$ of left ocular peduncle; with bifid terminal spine; mesial margin with 3-5 spines, lateral margin with 2 spines in distal half. Antennal flagellum shorter than carapace; each article with 1-4 long and 1 or 2 short setae.

Chelipeds subequal; left (Figure 12b) or right slightly larger; armature generally similar; dactyl and fixed finger without hiatus. Dactyl slightly longer than palm; dorsomesial margin with row of moderately large spines, decreasing in size distally and accompanied by sparse tufts of moderately long setae, adjacent dorsal surface with row of tuberculate spines and sparse tufts of setae; mesial face (Figure 12c) with 1 row of moderately large tuberculate spines or spinulose tubercles dorsally, occasionally row of widely-spaced protuberances or tubercles ventrally; cutting edge with row of small calcareous teeth in proximal 0.4-0.6, row of corneous teeth distally; terminating in small corneous claw, sometimes slightly overlapped by fixed finger. Palm approximately equal to length of carpus; dorsomesial margin with row of 4 or 5 prominent spines and tufts of setae, dorsolateral margin not delimited; weakly convex dorsal surface with several irregular rows of somewhat smaller tuberculate spines and sparse tufts of long setae, few rows extending nearly entire length of fixed finger; mesial face with scattered small tubercles or spinules, occasionally 1 or 2 irregular rows of 3-5 tubercles; ventral surface with few tubercles and sparse tufts of long setae; cutting edge of fixed finger with row of small calcareous teeth; terminating in small corneous claw. Carpus 0.5-0.6 length of merus; dorsomesial margin with row of 5 or 6 prominent, often corneous-tipped spines, dorsal surface with numerous spines, largest forming irregular median row, and sparse tufts of long setae, dorsolateral margin only weakly delimited by 1 or 2 irregular rows of spines; lateral face with irregular rows of small spines; mesial face with few tubercles or protuberances. Merus with few spines, sometimes corneous-tipped, on distal margin; dorsal margin with row of transverse, spinose or spinulose ridges accompanied by tufts of long setae; ventromesial margin with row of small spines and long setae; ventrolateral margin with few small spines in distal 0.3-0.5.

Second (Figure 12d, e) and third pereopods (Figure 12f) with dactyls 1.4-1.9 length of propodi; dorsal margins each with row of tufts of moderately long, stiff setae, few very small spines proximally on second pereopods; lateral faces each with weak longitudinal sulcus, at least proximally, and few to row of sparse tufts of short setae dorsally or medianly; mesial faces each with weak longitudinal sulcus and irregular, transverse rows of short setae, few to irregular row of tiny spinules ventrally in larger specimens; ventral margins each with row of 15-27 corneous spines. Propodi 1.1-1.4 length of carpi; dorsal margins each with row of few spines accompanied by tufts of moderately long setae on second pereopods, third with row of very small spinules or only tufts of moderately long setae, sometimes arising from low protuberances; mesial faces with few fine, moderately long setae; angular lateral surfaces each with dorsal row of low protuberances or spinules and sparse tufts of setae, row of sparse setae medianly; ventral surfaces each with row of low, sometimes spinulose protuberances and sparse tufts of setae. Carpi 0.60.8 length of meri; dorsal margins each with 


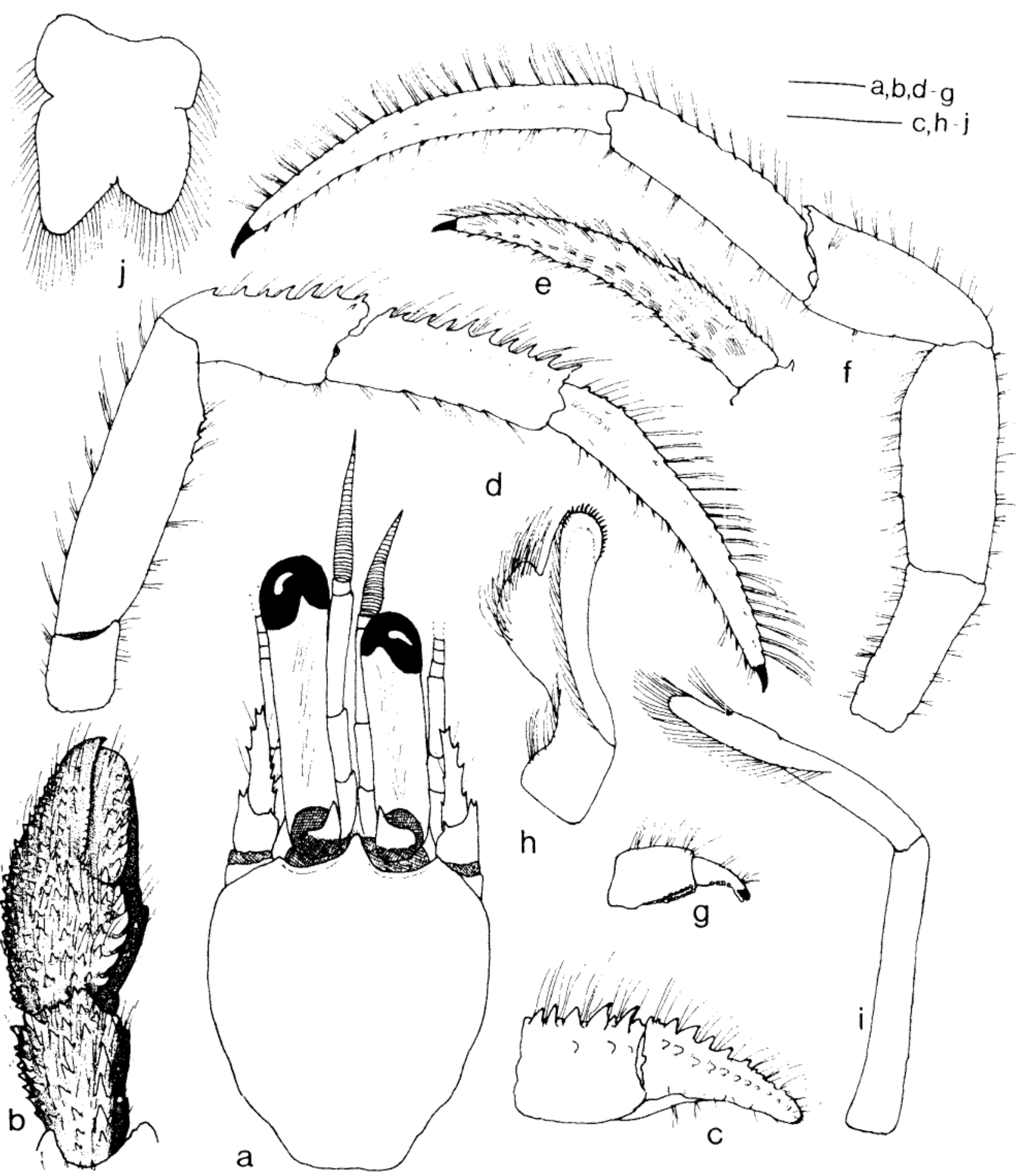

Figure 12 Paguristes simplex Rahayu and Mclaughlin, 2006. a-g, j, k, female paratype (4.3 mm) (WAM C 16715); h, i, male paratype $(7.4 \mathrm{~mm}$ ) (WAM C 16715). a, shield and cephalic appendages (aesthetases and some setae omitted); b, carpus and chela of left cheliped (dorsal view); c, left chela (mesial view); d, right second pereopod (lateral view); e, dactyl of right second pereopod (mesial view); $\mathbf{f}$, left third pereopod (lateral view); $\mathrm{g}$ dactyl and propodus of right fourth pereopod (lateral view); $h$, male left first pleopod; $\mathbf{i}$, male left second pleopod; $\mathbf{j}$, telson. Scales equal $1 \mathrm{~mm}$.

irregular row of moderately large spines (second) or dorsodistal spine and sometimes row of very small spines (third); lateral faces each with weak longitudinal sulcus and frequently small spine dorsally. Meri each with dorsal row of low protuberances and tufts of moderately short setae; ventral margins of second pereopods each with row of small spines in distal half and tufts of moderately short setae, third unarmed but with sparse tufts of setae. Fourth pereopods (Figure 12g) each with small preungual process at base of claw

Male first pleopods (Figure 12h) each with row of 
moderately short setae on lateral margin of inferior lamella, row of large, slender hooked spines on distal margin, continued down inner margin and decreasing in size; external lobe reaching distal margin of inferior lamella; internal lobe short, with long marginal setae extending onto inner face. Second pleopods (Figure 12i) with basal segment naked, distal segment with tuft of setae distally on endopod, appendix masculina with row of long marginal setae. Female gonopores paired; brood pouch subovate, with marginal plumose setae. Tergites of left pleonal somites 2-4 each with thickened margin and row of long, dense, plumose setae.

Telson (Figure 12j) with moderately deep lateral incisions separating anterior and posterior lobes; asymmetrical posterior lobes separated by very shallow, slit-like median cleft; left lobe usually appreciably elongate, both lobes subtriangular with rounded apices, terminal and lateral margins each with row of long setae.

\section{Colour (in preservative)}

Most color lost; however, ocular peduncles retain a solid tint of colour.

\section{Habitat}

Not reported.

\section{Distribution}

Madagascar and off Pt. Hedland, Western Australia; 200-255 m.

\section{Variation}

As reported by Rahayu and McLaughlin (2006), noticeable variation may be seen in the strength of the armature of the ambulatory legs. These authors considered this variation growth related. Females are not known from Madagascar, but the brood pouch of the larger Australian female is appreciably broader than that of the smaller specimen illustrated by Rahayu and McLaughlin.

\footnotetext{
Affinities

Rahayu and McLaughlin (2006) considered $P$. simplex morphologically most closely allied to $P$. jalur and $P$. runyanae. But in having a single row of spines or tubercles on the mesial face of each dactyl of the chelipeds and the tendency for the dactyls of the second pereopods, at least, to develop sulci on the mesial and/or lateral faces, $P$. simplex is also allied to $P$. crinitimanus, $\mathrm{sp}$. nov. However, as previously noted, the chelipeds of $P$. simplex are subequal, whereas those of $P$. crinitimanus are grossly unequal.

The superficial similarity between $P$. simplex and P. palythophilus was also noted by Rahayu and McLaughlin (2006) and both species were found
}

sympatrically off Pt. Hedland. Nevertheless, the two taxa are immediately distinguishable by the presence, in the latter species, of 3-5 rows of spines or tubercles on the mesial faces of the dactyls of the chelipeds and the relatively smooth mesial faces of the palms that are usually armed with only two or three large tubercles dorsally.

\section{Remarks}

The torsos of two small males ( $\mathrm{sl}=2.3,2.4 \mathrm{~mm}$ ), accompanied only by a pair of disarticulated chelipeds, and one right second and one left third pereopod, appear to possibly represent $P$. simplex. These specimens, from Soela station 187 , southwest of Point Cloats $\left(23^{\circ} 39^{\prime} \mathrm{S}, 113^{\circ} 11^{\prime} \mathrm{E}\right)$ have not been included in this report because their identities cannot be established with certainty. The chelipeds agree with those of $P$. simplex in having a single row of small tubercles on the mesial face of each dactyl, however, that character is not unique to $P$. simplex. Neither has it been possible to determine with confidence to which body these appendages belong. Conspecificity also is questionable because it appears that the smaller, and immature, specimen exhibits somewhat different development of the second thoracic sternite.

\section{Paguristes pugil McCulloch, 1913 \\ Figure 13}

Paguristes sp. - Whitelegge, 1889: 232.

Paguristes pugil McCulloch, 1913: 341, fig. 50. Gordan, 1956: 323 (literature). - Morgan, 1987d: 733 (key). - Davie, 2002: 55.

\section{Material examined}

\section{Lectotype (herein designated)}

New South Wales. AM P 3008 (male, $7.1 \mathrm{~mm}$ ), Watson's Bay, Port Jackson.

\section{Other material examined}

Victoria. NMV J 12194 (1 male, $3.0 \mathrm{~mm}$ ), East Gippsland $\left(38^{\circ} 12.5 \mathrm{~S}, 147^{\circ} 49^{\prime} \mathrm{E}\right), 48 \mathrm{~m}, 28.02 .1971$; NMV J 52818 (1 female, 1.6 mm), NMV J 12817 (1 male immature, $1.7 \mathrm{~mm}$ ), off Lakes Entrance; NMV J 17484 (1 female, $1.5 \mathrm{~mm}$ ), NMV J 17485 ( 3 males immature, $1.7-2.0 \mathrm{~mm}$; 5 females, $1.9-4.0 \mathrm{~mm} ; 1$ ovig. female, $3.3 \mathrm{~mm}$ ), southern Port Phillip (38 $21.54^{\prime} S$, $144^{\circ} 48.48^{\prime} \mathrm{E}$ ); NMV J 11767 (3 ovig. females, $2.4-3.3 \mathrm{~mm}$ ), off East Moncoeur I. (39 15.4'S, 146 32.0'E); NMV J 11765 (1 male, 4.5 $\mathrm{mm})$, off Crib Pt $\left(38^{\circ} 20,2^{\prime} \mathrm{S}, 145^{\circ} 14.3^{\prime} \mathrm{E}\right)$. Tasmania. NMV J 52813 (1 ovig. female, $2.2 \mathrm{~mm}$ ), stn K7/73-31, eastern Bass Strait $\left(38^{\circ} 33.1^{\prime} \mathrm{S}, 147^{\circ} 40.7^{\prime} \mathrm{E}\right), 43 \mathrm{~m}$, 29.11.1973; NMV J 11786 (1 ovig. female, $2.4 \mathrm{~mm}$ ), $\left(39^{\circ} 14.8^{\prime} \mathrm{S}, 147^{\circ} 31.5^{\prime} \mathrm{E}\right), 57 \mathrm{~m}, 18.11 .1981$. 


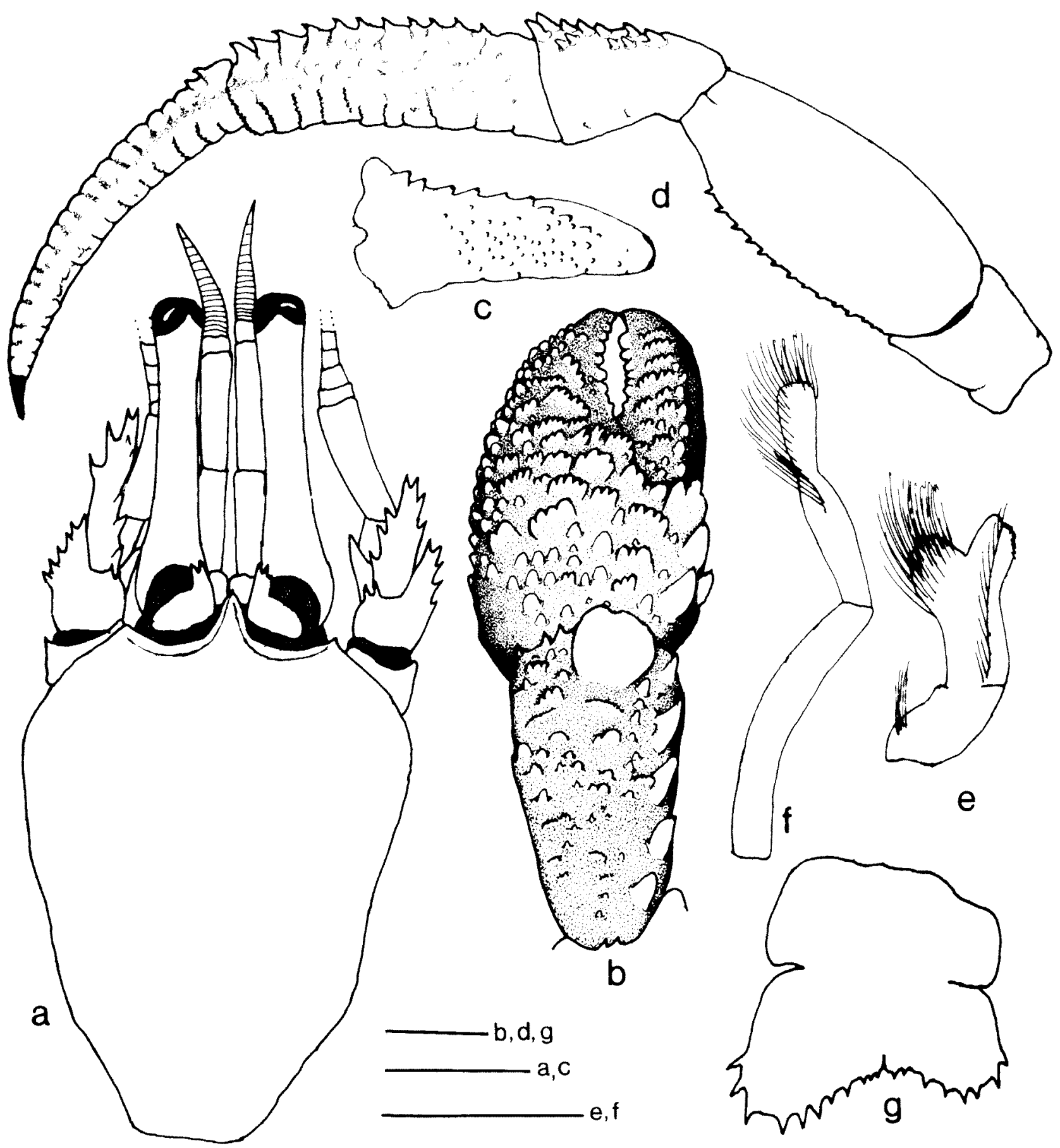

Figure 13 Paguristes pugil McCulloch, 1913, a, b, d, g, lectotype male (7.1 mm) (AM P 3008); c, e, f, male (4.5 mm) (NMV J 11765). a, shield and cephalic appendages (aesthetases and setae omitted); $\mathbf{b}$, chela and carpus of left cheliped (dorsal view, setae omitted); c, dactyl of left chela (mesial view, setae omitted); d, right second

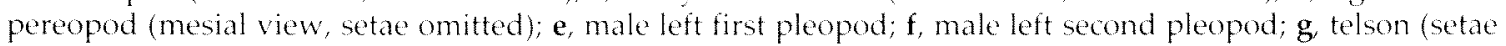
omitted). Scales equal $2 \mathrm{~mm}(\mathrm{a}, \mathrm{b}, \mathrm{d})$ and $1 \mathrm{~mm}(\mathrm{c}, \mathrm{e}, \mathrm{f}, \mathrm{g})$.

\section{Abbreviated redescription}

Gills biserial. Shield (Figure 13a) appreciably longer than broad. Rostrum triangular to narrowly triangular, usually reaching midlength of ocular acicles, with terminal spinule. Lateral projections each with very small terminal spinule. Ocular peduncles somewhat swollen basally, slender distally, 0.4-0.7 length of shield; dorsal and mesial surfaces each usually with 1 or 2 tufts of moderately long, plumose setae; corneas $0.1-0.2$ of peduncular length; ocular acicles simple, bi- or trifid. Antennular peduncles reaching from bases to slightly beyond distal margins of corneas. Antennal peduncles reaching beyond proximal 0.5 of ocular peduncles, but not to bases of corneas; fourth segment with very small dorsodistal spine; third segment often prominently produced ventrodistally, with $2-5$ small spines marginally; 
second segment with dorsolateral distal angle produced, with terminal bifid spine and 1-4 additional spines on lateral margin partially concealed by plumose setae, dorsomesial distal angle with 1 or 2 spines. Antennal acicle usually reaching midlength of fifth peduncular segment or beyond, with bifid terminal spine; mesial margin with 2-4 spines, lateral margin with 1 or 2 spines, all concealed by long, plumose setae. Antennal flagellum shorter than carapace, articles each with 1-4 moderately long setae.

Chelipeds subequal, similar in armament and ornamentation. Dorsal surfaces of chelas (Figure 13b) each with covering of dense, plumose setae, longest marginally, and practically concealing all armature; with or without distinct hiatus between dactyl and fixed finger. Dactyl with row of moderately small tuberculate spines in proximal 0.5 of dorsomesial margin, flattened dorsal surface with irregular, transverse rows of tuberculate spines, becoming squamiform tubercles with increased animal size, few simple tubercles proximally; mesial face (Figure 13c) with scattered small and very small, corneouscapped tubercles and sparse tufts of setae in distal 0.7; ventral surfaces with scattered tufts of setae; cutting edge with row of calcareous teeth, terminating in corneous claw. Palm with 3 large tuberculate spines on dorsomesial margin, distalmost bifid in lectotype, dorsal surface with individual tuberculate spines in small specimens, some becoming numerous squamiform tubercles in large individuals; mesial face practically glabrous, lateral and ventral surfaces with scattered tufts of moderately long setae. Carpus with 4 or 5 large, corneous-tipped spines on dorsomesial margin, dorsal surface each with scattered smaller tuberculate spines and simple and/or squamiform tubercles, almost entirely concealed by dense plumose setae, dorsodistal margin with few small corneous-tipped spines laterally and very large rounded boss over-lapping dorsal articulation with palm; mesial, lateral and ventral surfaces with scattered tufts of setae, distal margins each with row of long, plumose setae. Merus with 1 or 2 small spines at dorsodistal margin, dorsal surface with row of tufts of long, plumose setae; ventromesial margin with row of moderately prominent spines, ventrolateral margin with row of smaller spines, ventral surface with scattered small spines and tubercles.

Second (Figure 13d) and third pereopods with dense, long plumose setae on dorsal and ventral margins of all segments. Dactyls slightly shorter to slightly longer than propodi; dorsal margins of second pereopods each usually with 1 or 2 small spines at proximal margin; lateral surfaces each with faint longitudinal sulcus lined with row of tufts of setae, mesial faces each with weak longitudinal sulcus flanked dorsally and ventrally by row of squamiform indentations marginally lined with setae and frequently denticulate; ventral margins each with row of corneous spines or spinules, almost entirely concealed by dense, plumose setae. Propodi of second pereopods each with row of spines on dorsal surface, third unarmed; faint longitudinal sulcus on each lateral face, lined with row of tufts of setae; mesial faces each with squamiform indentations dorsally and ventrally, marginally lined with setae and often denticulate, at least ventrally. Carpi each with irregular double row of spines dorsally, smallest on third pereopods; lateral faces each with deep longitudinal sulcus lined with dense, long plumose setae. Meri each with small spine at dorsodistal margin and row of tufts on long setae on dorsal margin; laterodistal margins each with spine distally, larger and corneous-tipped on second pereopods; ventral margins each with row of spines (second pereopods) or low protuberances (third pereopods). Fourth pereopods (missing in lectotype) each with preungual process.

Male first pleopods (Figure 13e) each with row of small, rather widely-spaces spinules on distal margin of inferior lamella; external lobe slightly overreaching distal margin of inferior lamella; internal lobe short, with long setae marginally and on inner surface. Second pleopods (Figure 13f) each tuft on long setae distally on endopod; appendix masculina ovate, with setae marginally and on inner surface. Female brood pouch large, ovate, completely enclosing eggs attached to pleopods 2-4.

Telson (Figure 13g) with very prominent lateral incisions separating anterior and posterior portions; distinctly asymmetrical posterior lobes separated by short, slender median cleft; terminal margins each with row of spines extending slightly onto lateral margins.

\section{Colour (in preservative)}

Whitish or with faint orange tint; bosses occasionally retaining bright red-orange colour.

\section{Habitat}

Gastropod shells.

\section{Distribution}

Southeastern Australia.

\section{Variation}

The lectotype is a large specimen in which the squamiform tubercles thought by McCulloch (1913) to be typical of the species (Figure 13b) are clearly developed. However, in the numerous smaller specimens examined, the spines on the dorsal surfaces of the chelas are most frequently individual small tuberculate spines. Nevertheless, the boss 
developed on the dorsodistal margin of the carpus of each cheliped in even the smallest of specimens provides an unmistakable identifying character.

\section{Affinities}

Among Australian species, $P$. pugil is most closely allied with P. squamosus McCulloch, 1913 and $P$. geminatus sp. nov. All three are distinguished from the other regional species with spinose or spinulose telsonal margins by the squamiform armament of the subequal chelipeds and ambulatory legs. However, the large boss developed on the dorsodistal surface of the carpus of each cheliped immediately sets $P$. pugil apart.

\section{Remarks}

The large male from Watson Bay is clearly the specimen upon which McCulloch (1913) based his description.

However, he indicated that there was another smaller specimen in the museum collections and three that he had been sent from Port Phillip, Victoria. These additional specimens have not been reexamined. In the interest in stability in nomenclature, the Watson Bay specimen is herein designated as the lectotype of Paguristes pugil.

\section{Paguristes geminatus sp. nov.} Figure 14

Paguristes squamosus. - Tudge, 1995: 40 (in part). Davie, 2002: 56 (in part). (see Remarks)

\section{Material examined}

\section{Holotype}

Queensland. QM W 11360 (male, 7.4 mm), Davs Gutter, Moreton I., 1.5 m, coll. L. Lee, 16.10.1975.

\section{Description}

Gills biserial. Dorsal margin of branchiostegites unarmed but with row of fine, long setae. Shield (Figure 14a) very slightly longer than broad; dorsal surface rugose (not illustrated) and with few spinules laterally and small to moderately prominent spines marginally; anterior margin between rostrum and lateral projections weakly concave; anterolateral margins sloping; posterior margin roundly truncate. Rostrum broadly rounded, exceeding lateral projections little if at all. Lateral projections broadly rounded, with or without terminal spinule. Ocular peduncles moderately slender, 0.7 length of shield, dorsal surfaces glabrous; corneal diameter 0.2 of peduncular length; ocular acicles terminating acutely; separated by approximately 0.5 basal width of 1 acicle.

Antennular peduncles, when fully extended, reaching bases of corneas; ultimate and penultimate segments each with few short setae; basal segment with small spine on dorsolateral margin of statocyst lobe and more prominent spine on distal segmental margin.

Antennal peduncles 0.6-0.7 length of ocular peduncles; fifth segment with few scattered short setae; fourth segment with small dorsodistal spine; third segment ventrodistal margin prominently produced and terminating in acute spine; second segment with dorsolateral distal angle produced, terminating in bifid spine and with 2 spines on lateral margin, dorsomesial distal angle with 1 spine; first segment with 1 or 2 spines on dorsolateral margin; 1 spine on ventrodistal margin laterally. Antennal acicles reaching beyond midlength of fifth peduncular segments, each terminating in bifid spine, with 2 or 3 spines on lateral margin distally and 1 prominent and 1 much smaller spine on mesial margin proximally, all partially concealed by long setae. Antennal flagella broken; each article with several moderately short, randomly set setae.

Chelipeds (Figure 14b) subequal, similar; dorsal surfaces of chelas and carpi with moderate to dense covering of generally short setae, becoming much longer marginally and partially concealing armature. Dactyls approximately 2.0 longer than palms, dorsomesial margins each with row of bluntly corneous-tipped, tuberculate spines decreasing in size distally, flattened dorsal surfaces with irregular transverse rows of squamiform tubercles each with marginal very short bristles; mesial faces (Figure 14c, d) each with 3 slightly oblique, relatively regular rows of corneous-capped small tubercles, few sparse tufts of setae ventrally; ventral surfaces with few tufts of long setae; cutting edges each with row of moderately small calcareous teeth in proximal 0.5 , row of corneous teeth distally. Palms each with 3 large, corneous-tipped spines on dorsomesial margin, flattened dorsal surfaces of palms and fixed fingers with numerous transverse rows of squamiform tubercles, each with marginal row of short, stiff bristles, dorsolateral margins each with row of moderately small spines on fixed finger, becoming bluntly corneous-tipped on palm, lateral faces somewhat tuberculate; mesial faces of palms and ventral surfaces of palms and fixed fingers with tufts of long setae; cutting edges of fixed fingers each with row of small calcareous teeth, fused corneous teeth distally forming large claw. Carpi each with row of 5 large, corneoustipped spines on dorsomesial margin, dorsodistal margin with row small, subacute spines, dorsolateral margin not delimited, dorsal and lateral surfaces with irregular rows of subacute spines; mesial and ventral surfaces with tufts of long setae marginally. Meri each with row of small spines on dorsodistal margin extending down laterodistal margin, 2-4 subacute spines subdistally, 


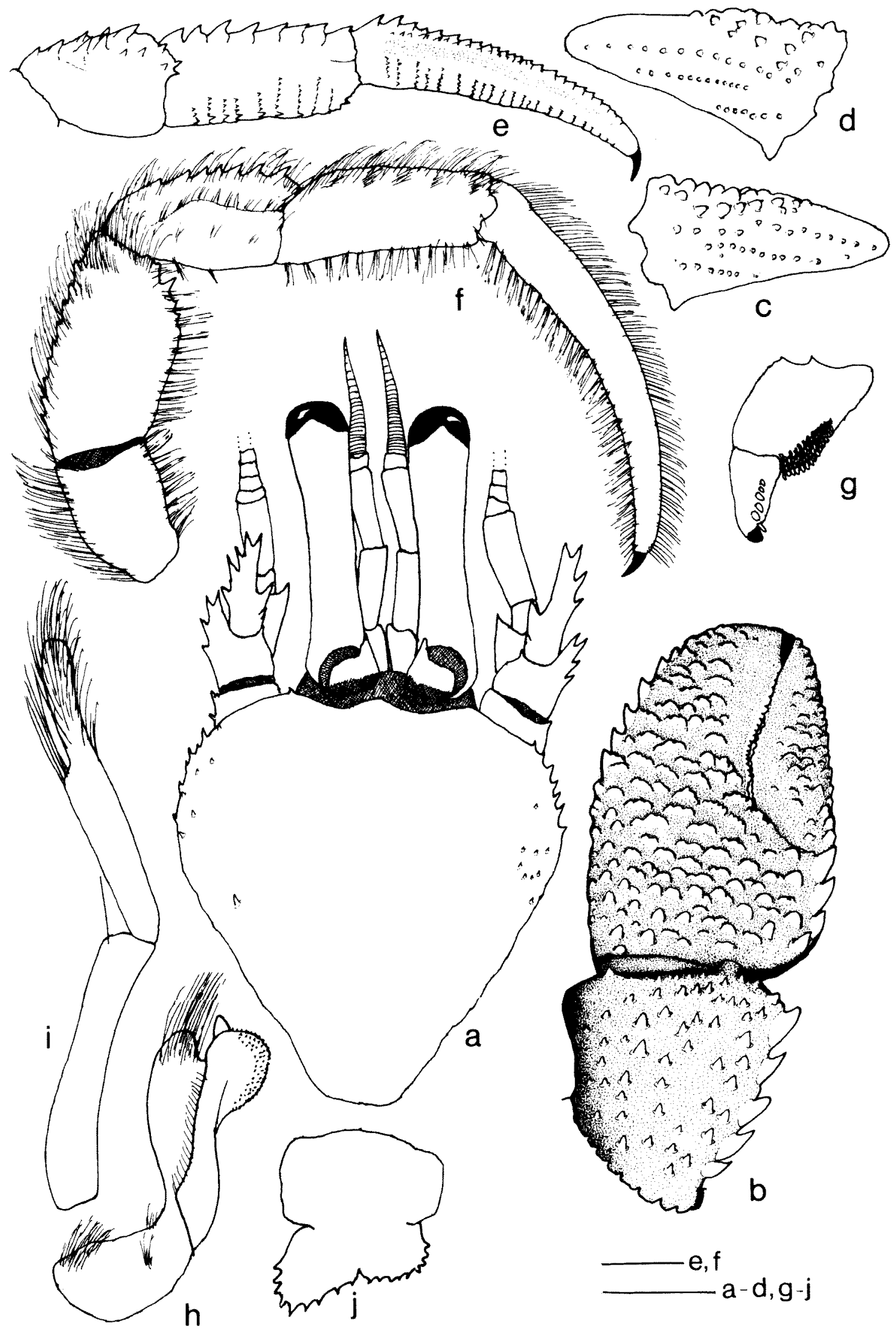

Figure 14 Paguristes geminatus sp. nov, male holotype (7.4 mm) (QM W 11360). a, shield and cephalic appendages (aesthetascs and setae omitted); $\mathbf{b}$, chela and carpus of left cheliped (dorsal view, setae omitted); $\mathbf{c}$, dactyl of left chela (mesial view, setae omitted); d, dactyl of right chela (mesial view, setae omitted); e, dactyl, propodus, carpus of left second pereopod (mesial view, setae omitted); $\mathbf{f}$, right third pereopod (lateral view); $\mathbf{g}$, dactyl and propodus of left fourth pereopod (setae omitted); $\mathbf{h}$, male left first pleopod; $\mathbf{i}$, male left second pleopod; $\mathbf{j}$, telson (setae omitted). Scales equal $2 \mathrm{~mm}(\mathrm{a}-\mathrm{g}, \mathrm{j})$ and $1 \mathrm{~mm}(\mathrm{~h}, \mathrm{i})$. 
remaining dorsal surface with row of low, subacute spines and tufts of long setae; lateral face weakly tuberculate, ventrolateral and ventromesial margins each with row of small spines; ventral surface with covering of long, plumose setae. Ischia each with row of very small, subacute spines on ventromesial margin, partially obscured by long setae

Second (Figure 14e) and third (Figure 14f) pereopods generally similar, dorsal and ventral margins of all segments obscured by long, quite dense setae. Dactyls 1.4-1.8 length of propodi; dorsal surfaces of second pereopods each with row of small, corneous-tipped spines extending nearly to tip, third pereopods with row of blunt, corneous spinules; lateral faces each with scattered tufts of setae, second with short, shallow longitudinal sulcus proximally; mesial faces of second pereopods weakly concave, each cut ventrally by scute-like marginally spinulose indentations, most prominent proximally; ventral margins each with 20-25 corneous spines. Propodi of second pereopods each with row of spines on dorsal surface, third with few smaller spines; lateral faces each with longitudinal rows of tufts of setae; mesial faces each with squamiform, spinulose indentations or scute-like ridges ventrally, weaker on third pereopods. Carpi each with irregular double row of spines dorsally, smallest on third pereopods; lateral faces each with deep longitudinal sulcus lined with long setae. Meri each with row of low protuberances and tufts of long setae on dorsal margin of second pereopods, row of small spines on third; laterodistal margins each with spine distally; ventral margins each with row of small spines, smallest on second. Fourth pereopods (Figure 14g) each with moderately well developed preungual process at base of claw; lateral faces each with irregular row of 4-5 corneous scales. Propodal rasp consisting of 4-5 rows of small corneous scales.

Male first pleopods (Figure 14h) each with tuft of setae at proximomesial angle, row of short setae on outer margin of inferior lamella; distal margin with tiny, corneous teeth, arranged in 3-4 somewhat irregular rows; external lobe broadly triangular distally, considerably overreaching distal margin of inferior lamella; internal lobe moderately long, with long setae on inner surface distally. Second pleopods (Figure 14i) each with distal seta on basal segment; endopod with terminal tuft of moderately long setae, appendix masculina with scattered long setae on outer surface. Female unknown

Telson (Figure 14j) with moderately deep lateral incisions indicating anterior and posterior portions; asymmetrical posterior lobes separated by shallow median cleft; terminal margins each with row of well developed spines extending onto lateral margins, spines of left lobe slightly larger.

\section{Colour}

Not known, but presumably similar to $P$. squamosus.

\section{Habitat}

Shallow intertidal

\section{Distribution}

Known only from the type locality.

\section{Etymology}

The specific epithet is derived from the Latin gemino meaning pair or double and referring to the striking similarities this species shares with $P$. squamosus.

\section{Affinities}

Paguristes geminatus sp. nov. is very closely allied to $P$. squamosus and was mistakenly cited as the latter species by Tudge (1995) and Davie (2002).

Variability in the new species cannot be assessed at present, but the shield of the holotype of $P$. geminatus is only very slightly longer than broad, whereas the shields of the examined specimens of $P$. squamosus all were distinctly much longer than broad. The ocular peduncles of all $P$. squamosus specimens were provided with a tuft of setae on the dorsal proximal surface that was absent in $P$. geminatus. The two species are immediately separable by the armature of the mesial faces of the dactyls of the chelipeds that in $P$. geminatus consist or three slightly oblique rows of corneous-capped small tubercles

\section{Remarks}

Only two species of Paguristes s.l. were listed by Tudge (1995) in his report on the hermit crabs of the Great Barrier Reef and coastal Queensland. Although both he and Davie (2002) included McCulloch's (1913) locality data, their records of Paguristes squamosus from Queensland were based on the specimen from Moreton Bay in the collections of the Queensland Museum (P. Davie, personal communication) described herein as $P$. geminatus.

\section{Paguristes squamosus McCulloch, 1913}

Figure 15

Paguristes barbatus. - Whitelegge, 1889: 232. - Stead, 1898: 208. Not Paguristes barbatus (Heller, 1862).

Paguristes squamosus McCulloch, 1913: 338, fig. 49 - Gordan, 1956: 324 (literature). - Griffin, 1967: 306. - Kunze and Anderson, 1979: 697, figs 6a, b, $9,11,17,23 \mathrm{e}, \mathrm{f}, 24 \mathrm{c}, 26 \mathrm{c}, 29,31,34,27$. - Morgan, 1987d: 733 (key). - Tudge, 1995: 40 (in part). Davie, 2002: 56 (in part). 


\section{Material examined}

\section{Holotype}

New South Wales. AM P 3005 (male, $17.3 \mathrm{~mm}$ ), Maroubra.

\section{Other material examined}

New South Wales. AM P 21791 (1 male, $11.3 \mathrm{~mm}$; 1 ovig. female lacking most appendages, $5.5 \mathrm{~mm}$ ), Warden Head, Ulladula, 05.01.1970; NMV J 11751 (1 male, $9.9 \mathrm{~mm}$ ), Skennars Head (28 $\left.50^{\prime} \mathrm{S}, 153^{\circ} 37^{\prime} \mathrm{E}\right)$, $1 \mathrm{~m}, 26.09 .1981$; NMV J 17015 (2 males, 5.5, $5.7 \mathrm{~mm}$ ), Woody Head (29 $\left.22^{\prime} \mathrm{S}, 153^{\circ} 22^{\prime} \mathrm{E}\right), 1 \mathrm{~m}, 29.09 .1981$; AM P 11019 (1 male, $12.8 \mathrm{~mm}$ ), S of Angourie Pt (29 32'S, 153 21'E), coll. A.A. Cameron, 01.1939; AM P 53239 (1 male, $10.7 \mathrm{~mm}$ ), Newport (33⒊' $161^{\circ} 19^{\prime} \mathrm{E}$ ), coll. I. Bennett; AM G 2291 (1 male, 13.5 $\mathrm{mm})$, Balmoral Beach, Port Jackson $\left(3^{\circ} 49.7^{\prime} \mathrm{S}\right.$, 151 15.1'E), coll. J. Bragg; SAMA PC 0316 (1 male, $10.0 \mathrm{~mm})$, Malabar Bay, 3-5 m, coll. K. GowlettHolmes, 07.09.1998; NMV J 14591 (1 male, 8.5 mm), Flinders Islet, Port Kembla Reef $\left(34^{\circ} 29^{\prime} \mathrm{S}, 150^{\circ} 55^{\prime} \mathrm{E}\right)$, $15 \mathrm{~m}$, coll. J.E. Watson; AM P 7157 (1 male, $9.6 \mathrm{~mm}$ ), Shell Harbour, $34^{\circ} 35^{\prime} S, 150^{\circ} 53^{\prime} \mathrm{E}$, coll. F.A. McNeil; NMV J 11752 (3 males, 7.5-12.3 mm; 1 female, 10.0 $\mathrm{mm})$, Mystery Bay $\left(36^{\circ} 18^{\prime} \mathrm{S}, 150^{\circ} 09^{\prime} \mathrm{E}\right), 1 \mathrm{~m}$, 12.04.1972.

\section{Redescription}

Gills biserial. Unarmed dorsal margins of branchiostegites completely concealed by long, plumose setae. Shield (Figure 15a) considerably longer than broad; surface rugose (not illustrated), weakly spinulose, particularly laterally, and with scattered tufts of setae. Rostrum narrowly triangular, reaching nearly to midlength of ocular acicles or slightly beyond midlength. Ocular peduncles slender, $0.5-0.7$ length of shield, dorsal surfaces each with moderately dense tuft of long setae proximally; corneal diameter $0.1-0.2$ of peduncular length; ocular acicles each with 2-4 small spines on oblique lateral margin. Antennular peduncles not reaching bases of corneas in holotype, reaching beyond bases but not reaching to distal corneal margins in smaller specimens; basal segment with small to prominent spine on dorsolateral margin of statocyst lobe. Antennal peduncles $0.6-0.8$ length of ocular peduncles; fourth segment with small dorsodistal spine or spinule; third segment ventrodistal margin prominently produced and terminating in acute spine; second segment with dorsolateral distal angle produced, terminating in simple or bifid spine and with $0-3$ spines on lateral margin, dorsomesial distal angle with 1 or 2 spines. Antennal acicles reaching to or almost to distal margin of fifth peduncular segments, each terminating in simple or bifid spine, with 1-3 spines on lateral margin distally and 0-1 spine on mesial margin proximally, all entirely concealed by dense long setae. Antennal flagellum shorter than shield; each article with several moderately long, randomly set setae.

Chelipeds (Figure 15b) subequal, similar; dorsal surfaces of chelas and carpi with moderate to dense covering of generally short setae, becoming much longer marginally and almost completely concealing armature. Dactyl longer than palm, dorsomesial margin with 4 or 5 small, often corneous-tipped, tuberculate spines proximally, flattened dorsal surface with irregular transverse rows of marginally denticulate, squamiform tubercles; mesial face (Figure 15c) with individual or scute-like marginally denticulate protuberances dorsally and ventrally obscured by moderately long, dense setae and with few tufts of shorter setae medianly; ventral surface with tufts of long setae; cutting edge with row of moderately small calcareous teeth in proximal $0.5-0.6$, row of large corneous teeth distally, tending to fuse into hooflike corneous claw in large specimens. Palm with 3 large, corneous-tipped spines on dorsomesial margin, flattened dorsal surfaces of palm and fixed finger with numerous transverse rows of simple and marginally denticulate and corneous-tipped, squamiform tubercles, dorsolateral margin with row of moderately small spines on fixed finger, becoming more tuberculate on palm, mesial face of palm and lateral and ventral surfaces of palm and fixed finger with tufts of long setae; cutting edge of fixed finger with row of small calcareous teeth, corneous teeth distally, tending to fuse into large corneous claw in large specimens. Carpus with row of 4 large, corneous-tipped spines on dorsomesial margin, dorsodistal margin with 7-9 small, subacute or acute and corneous-tipped spines, dorsolateral margin with row of small spines and tubercles, dorsal surface with transverse rows of simple and marginally denticulate, often corneoustipped, squamiform tubercles; mesial and lateral faces with tufts of long setae, particularly dorsally, 1 dense tuft of long setae at ventrolateral distal angle. Merus with well developed protuberance or spine at dorsodistal margin and 1 similar protuberance or spine subdistally, remaining dorsal surface with row of low protuberances and tufts of long setae; ventrolateral and ventromesial margins each with row of small spines at least in distal halves, at least partially concealed by tufts of long setae. Ischium with row of very small, subacute spines on ventromesial margin, usually obscured by long setae.

Second (Figure 15d) and third pereopods generally similar, dorsal and ventral margins of all segments obscured by long, very dense setae. Dactyls equal to length of propodi or slightly longer, moderately stout; dorsal surfaces of second pereopods each usually with 1 or 2 small spines proximally, third pereopods without spines; lateral 


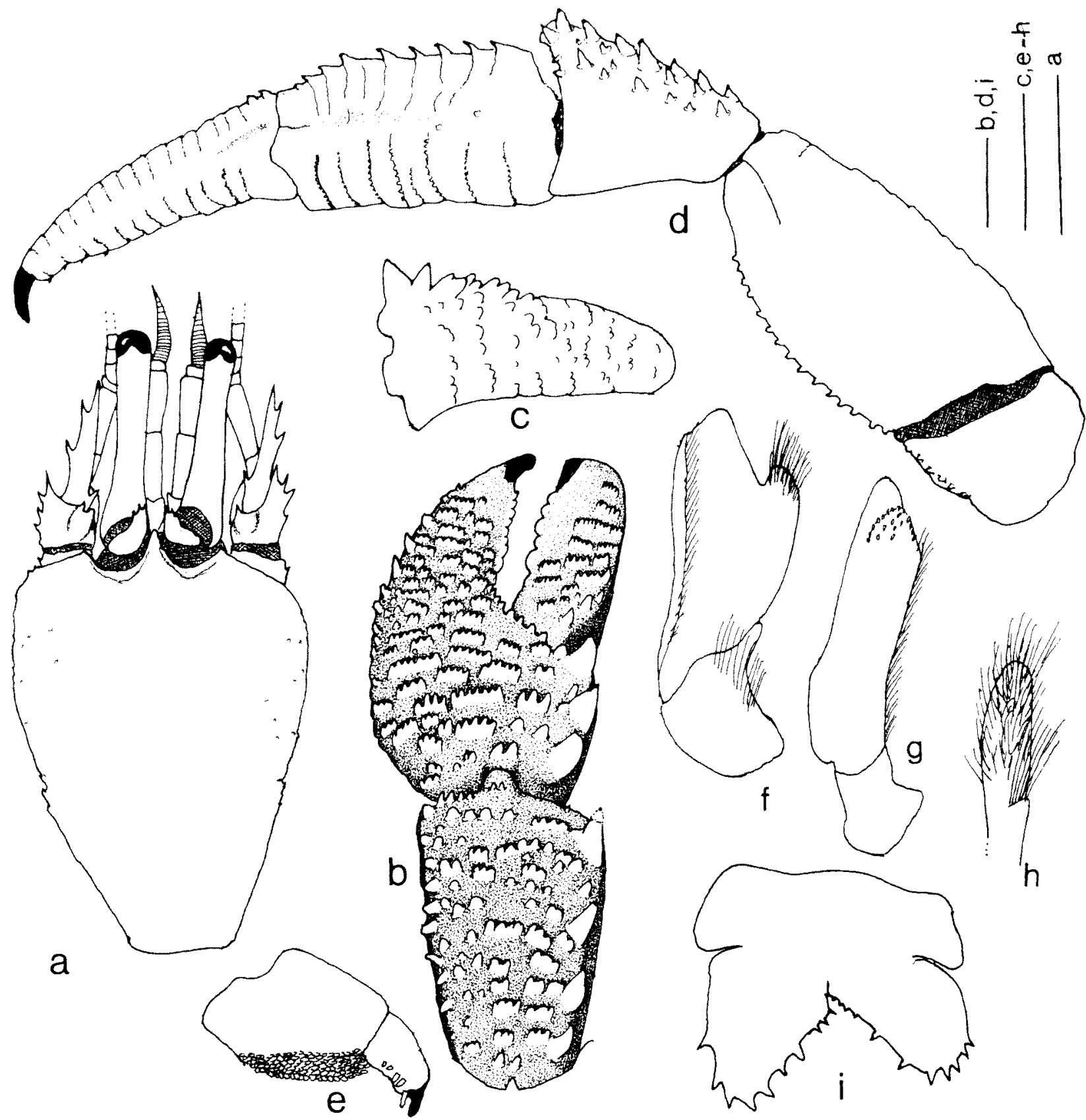

Figure 15 Paguristes squamosus McCulloch, 1913, a, b, d, j, holotype male (17.3 mm) (AM P3005); $\mathbf{c}$, e-i, male (9.6 $\mathrm{mm}$ (AM P7157). a shield and cephalic appendages (aesthetascs and setae omitted); $b$, chela and carpus of left cheliped (dorsal view, setae omitted); c, dactvl of left chela (mesial view, setae omitted); $d$, right second pereopod (mesial view, setae omitted); e, dactyl and propodus of right fourth pereopod (lateral view, setae omitted); $\mathbf{f}, \mathbf{g}$, right male first pleopod; $\mathbf{h}$, distal portion of endopod and appendix masculina of right male second pleopod; i, telson (setae omitted). Scales equal $5 \mathrm{~mm}$ (a), $2 \mathrm{~mm}$ (b-e, i) and $1 \mathrm{~mm}$ (f-h).

faces each with weak longitudinal sulcus proximally and row of tufts of setae in midline; mesial faces each cut dorsally and ventrally by scute-like indentations, each with marginal row of setae and denticles, frequently comeous-tipped and most prominent proximally; ventral margins each with few corneous spines distally. Propodi of second pereopods each with row of spines on dorsal surface, third unarmed, 2 longitudinal rows of tufts of setae on lateral faces; mesial faces each with squamiform indentations or scute-like ridges dorsally and ventrally, marginally lined with setae and denticulate or spinulose, at least ventrally. Carpi each with irregular double row of spines dorsally, smallest on third pereopods; lateral faces each with deep longitudinal sulcus lined with dense, long setae. Meri each with row of low protuberances and tufts of long setae on dorsal margin of second pereopods, row of small spines on third; laterodistal margins each with spine 
distally; ventral margins each with row of small spines. Fourth pereopods (Figure 15e) each with well developed preungual process at base of claw; lateral faces each with irregular row of $4-8$ corneous scales. Propodal rasp consisting of 6-8 rows of small corneous scales.

Male first pleopods (Figure 15f, g) each with row of short setae on outer margin of inferior lamella; distal margin with widely-spaced, tiny, corneous teeth arranged in 3 or 4 irregular rows; external lobe broadly triangular distally, considerably overreaching distal margin of inferior lamella; internal lobe short, with long setae marginally and on inner surface Second pleopods with elongate naked basal segment; endopod with terminal tuft of moderately long setae, appendix masculina (Figure 15h) with scattered long setae on outer surface, and marginal. Female brood pouch large, subcircular and with marginal setae.

Telson (Figure 15i) with deep lateral incisions indicating anterior and posterior portions; asymmetrical posterior lobes separated by slender median cleft; terminal margins each with row of well developed spines extending onto lateral margins, spines of left lobe largest.

\section{Colour (in life)}

"Pink with pale brownish hairs; rougher parts more or less tinted with green. Spines on chelipeds madder brown. Ocular peduncles green. Antennules, antennae, and third maxillipeds with alternating brown and white rings. Abdomen translucent gray and white, caudal appendages white" (McCulloch, 1913).

\section{Habitat}

Shallow subtidal.

\section{Distribution}

New South Wales, Australia.

\section{Affinities}

McCulloch (1913) differentiated P. squamosus from the very similar $P$. pugil by the more slender chelipeds and ambulatory legs, longer ocular peduncles and most importantly by the large rounded boss on each carpus of the latter species. Paguristes squamosus is also superficially very similar to $P$. geminatus sp. nov., sharing with the latter species the scute-like armature of the chelipeds and ambulatory legs and similar, albeit not quite so dense setation. As previously indicated, the two species are immediately distinguished by the armature of the mesial faces of the dactyls of the chelipeds that is composed of individual or scutelike, marginally denticulate, protuberances dorsally and ventrally in $P$. squamosus or consisting of three rows of small corneous-capped tubercles in $P$. geminatus.

\section{Remarks}

McCulloch (1913) reexamined Whitelegge's (1889) and Stead's (1898) specimens identified as $P$. barbatus and found them to be identical with $P$. squamosus. Although McCulloch (1913) did not realize that Ortmann (1892) also had misinterpreted Heller's (1862) P. barbatus, he (McCulloch, 1913: 340) was correct in his assessment that neither Heller (1862) nor Ortmann (1892) had described $P$. squamosus as $P$. barbatus.

The male first pleopods in $P$. squamosus are rather unusual both in the armature of the inferior lamellae and the fusion of the external lobe of the superior lamella with it. Instead of the customary marginal and sometimes additional one to three rows of moderate to prominent, hooked spines circumscribing the distal margin of the inferior lamella and adjacent outer surface, the inferior lamella of $P$. squamosus is provided with one widely-spaced row of minute corneous spinules on the distal margin and the adjacent outer surface has a few widely scattered, similarly minute spinules. The external lobe is fused to the inner surface of the inferior lamella immediately adjacent to the distal margin, rather that joining the inferior lamella more proximally as in most species.

\section{Paguristes dampierensis sp. nov.}

Figures 16, 17

\section{Material examined}

\section{Holotype}

Western Australia, Dampier Archipelago. WAM C 26003 (male, $5.6 \mathrm{~mm}$ ), stn DA2/99/54, $13 \mathrm{~km}$ WNW of NW point of Goodwyn I. (29.29.31's, $\left.116^{\circ} 25.18^{\prime} \mathrm{E}\right), 36-37 \mathrm{~m}, 21.07 .1999$.

\section{Paratypes}

Western Australia, Dampier Archipelago. WAM C 25976 ( 1 male, $1.3 \mathrm{~mm}$; 1 ovig. female, $2.9 \mathrm{~mm}$ ), $\operatorname{stn} \mathrm{DA} 2 / 99 / 23,16.5 \mathrm{~km} \mathrm{~W}$ of $C$. Legendre ( $\left.20^{\circ} 21.00^{\prime} \mathrm{S}, 116^{\circ} 40.39^{\prime} \mathrm{E}\right), 37.0 \mathrm{~m}, 17.07 .1999 ;$ WAM C 25951 (5 males, $2.1-3.9 \mathrm{~mm}$; 1 ovig. female, 3.0 $\mathrm{mm}$ ) and WAM C 25981 (2 males, 2.4, $2.9 \mathrm{~mm}$ ), stn DA2/99/24, $10.2 \mathrm{~km} \mathrm{~N}$ of Lady Nora I. $\left(20^{\circ} 21.79^{\prime} \mathrm{S}\right.$, 116 38.05'E), $38.5 \mathrm{~m}, 17.07 .1999$; WAM C 25932 (4 male, $2.4-6.8 \mathrm{~mm}, 1$ ovig. female, $3.8 \mathrm{~mm}$ ), stn DA2/ $99 / 25,9.4 \mathrm{~km} \mathrm{~N}$ of Rosemary I. $\left(20^{\circ} 22.29^{\prime} \mathrm{S}\right.$, $\left.116^{\circ} 35.56^{\circ} \mathrm{E}\right), 39 \mathrm{~m}, 17.07 .1999$; WAM C 25933 (2 males, $3.7,3.8 \mathrm{~mm}$; 1 female, $1.7 \mathrm{~mm}$; 2 ovig. females, 3.6, $4.2 \mathrm{~mm}$ ), stn DA2/99/26, $~ 5.8 \mathrm{n}$. mls NE of Rosemary I. $\left(20^{\circ} 24.01\right.$ 'S, $\left.116^{\circ} 41.28^{\prime} \mathrm{E}\right), 34 \mathrm{~m}$, 17.07.1999; WAM C 29560 (3 males, 2.9-3.5 mm), stn DA2/99/52, $18.5 \mathrm{~km} \mathrm{~W}$ of SW point of Goodwyn I. $\left(20^{\circ} 31.85^{\prime} \mathrm{S}, 116^{\circ} 21.48^{\prime} \mathrm{E}\right), 31.3-33.0-32.3 \mathrm{~m}$, 21.07.1999; WAM C 26004 (1 male, $4.4 \mathrm{~mm}$ ), stn DA2/99/56, $3.7 \mathrm{~km} \mathrm{~W}$ of Roly Rock (20 30.10's, 
$\left.116^{\circ} 28.27^{\prime} \mathrm{E}\right), 34.5 \mathrm{~m}, 21.07 .1999$; WAM C 26011 (2 males, $2.7,2.8 \mathrm{~mm})$, stn DA2/99/71, $8.5 \mathrm{~km} \mathrm{~S}$ of Rocky Head, Enderby I. $\left(20^{\circ} 41.49^{\prime} \mathrm{S}, 116^{\circ} 28.05^{\prime} \mathrm{E}\right)$, $10.5 \mathrm{~m}, 24.07 .1999$; WAM C 25964 (1 temale, 2.4 $\mathrm{mm})$, stn DA2/99/75, $1.4 \mathrm{~km} \mathrm{E}$ of $\mathrm{NE}$ point of Goodwyn I. (2032.16'S, $11633.70 ' \mathrm{E}), 14.0-9.0 \mathrm{~m}$, 25.07.1999; WAM C 25944 (1 male, 4.9 mm), stn DA2/99/79, $4.8 \mathrm{~km}$ WNW of W point of Kendrew $I$. (2027.64'S, $\left.116^{\circ} 29.54^{\prime} \mathrm{E}\right), 38.0 \mathrm{~m}, 25.07 .1999$.

\section{Other material examined}

Western Australia, Dampier Archipelago. WAM C 29561 (1 male, 3.8 mm, no chelipeds), stn DA2/99/ 26, $10.7 \mathrm{~km} \mathrm{NE}$ of Rosemary I. $\left(20^{\circ} 24.01^{\prime} \mathrm{S}\right.$, $116^{\circ} 41.28^{\prime} \mathrm{E}$ ), $34 \mathrm{~m}, 17.07 .1999$; NMV J 53126 (1 ovig. female, damaged), DA2 $401,7.8 \mathrm{~km}$ northwest of C. Legendre, Legendre I. (20 19.38'S, 116 45.45'E).

\section{Description}

Gills biserial. Shield (Figure 16a) slightly longer than broad to slightly broader than long; dorsal surface rugose (not illustrated), with few spines marginally and/or laterally, and numerous tufts of moderately long setae, particularly laterally. Lateral projections broadly triangular, subacute or rounded, with or without terminal spinule. Rostrum very broadly triangular or rounded, not reaching level of lateral projections, unarmed or with tiny terminal spinule; anterior margin with row of moderately dense setae. Branchiostegites with unarmed dorsal margins partially obscured by row of tufts of long, moderately dense setae, anterior margins each with 1 or 2 spinules.

Ocular peduncles moderately slender; 0.6-0.8 length of shield, left often longest; dorsal surface with sparse, moderately long setae most numerous basally; corneas $0.1-0.2$ of peduncular length. Ocular acicles subrectangular; terminal margins each with 3 or 4 moderately large and 1 or 2 smaller spines, partially obscured by setae; separated basally by less than basal width of 1 acicle.

Antennular peduncles when fully extended usually reaching to basal margins of corneas. Ultimate and penultimate segments with few moderately short setae. Basal segment with slender spine on dorsolateral margin of statocyst lobe, 1 smaller spine on laterodistal margin and 1 spine at ventromesial distal angle.

Antennal peduncles reaching from slightly less to slightly more than midlength of ocular peduncles. Fifth segment with few scattered moderately long setae. Fourth segment with dorsodistal spine. Third segment with prominent ventrodistal spine. Second segment with dorsolateral distal angle produced, terminating in bifid spine, 1 or 2 smaller spines on lateral margin and tufts of long setae; dorsomesial distal angle with 1 or 2 spines. First segment unarmed or with small spine at laterodistal margin partially obscured by long setae; ventrodistal margin with prominent spine. Antennal acicle reaching to approximately midlength of ultimate peduncular segment, with prominent, usually bifid terminal spine; mesial margin with 1 or 2 spines in proximal half, lateral margin with 1 or 2 spines, all partially obscured by long setae. Antennal flagellum shorter than carapace; each article with 14 long and 1 or 2 short, randomly-set setae.

Third maxilliped with or without 1 small spine on ventrodistal margin of ischium; dorsodistal margin of merus unarmed, ventral margin with 3 or 4 spines; carpus with dorsodistal margin unarmed.

Chelipeds (Figure 17a, b) subequal; left usually slightly larger; armature generally similar; dactyl and fixed finger with slender hiatus. Dactyl 2.0-2.8 length of palm; dorsomesial margin with row of low, tuberculate spines at least partially concealed by tufts of moderately long setae, dorsal surface with 2 similar rows of tuberculate spines and tufts of setae; mesial face (Figure $17 \mathrm{c}$ ) with 1 row of slightly smaller tuberculate spines medianly, often additional partial row dorsally, and usually row of more widely-spaced, low protuberances ventrally, all accompanied by tufts of long setae; cutting edge with row of small calcareous teeth in proximal $0.7-$ 0.8 , corneous teeth distally; terminating in small corneous claw and slightly to distinctly overlapped by fixed finger. Palm 0.7-0.8 length of carpus; dorsomesial margin with row of 3 prominent spines and tufts of setae, dorsolateral margin not delimited; weakly convex dorsal surface with 4-6 irregular rows of somewhat smaller tuberculate spines, at least partially concealed by tufts of long setae, 2 or 3 rows extending nearly entire length of fixed finger, 1 very prominent tuberculate spine at junction of dactyl and fixed finger; lateral surface with rows of shallow pits and tufts of long setae; mesial and ventral surfaces unarmed but with tufts of moderate to long setae; cutting edge of fixed finger with row of small calcareous teeth; terminating in small corneous claw. Carpus slightly more than half length of merus; dorsomesial margin with row of 5 prominent spines, 1 very conspicuous tuberculate spine at dorsodistal margin mesially, dorsal surface with scattered, low, sometimes spinulose protuberances and scattered setae, densest marginally, dorsolateral row of spines; lateral and mesial faces each with row of protuberances; ventrodistal margin with 1 or 2 flattened, spinulose protuberances. Merus with moderate to long setae on dorsodistal margin; dorsal margin with row of transverse, sometimes spinulose ridges accompanied by tufts of long setae; ventromesial and ventrolateral margins each with row of small spines or spinules and long setae. Ischium with row of spinules on ventromesial margin.

Second and third pereopods (Figure $17 \mathrm{~d}-\mathrm{g}$ ) with dactyls 1.2-1.4 length of propodi; dorsal margins 


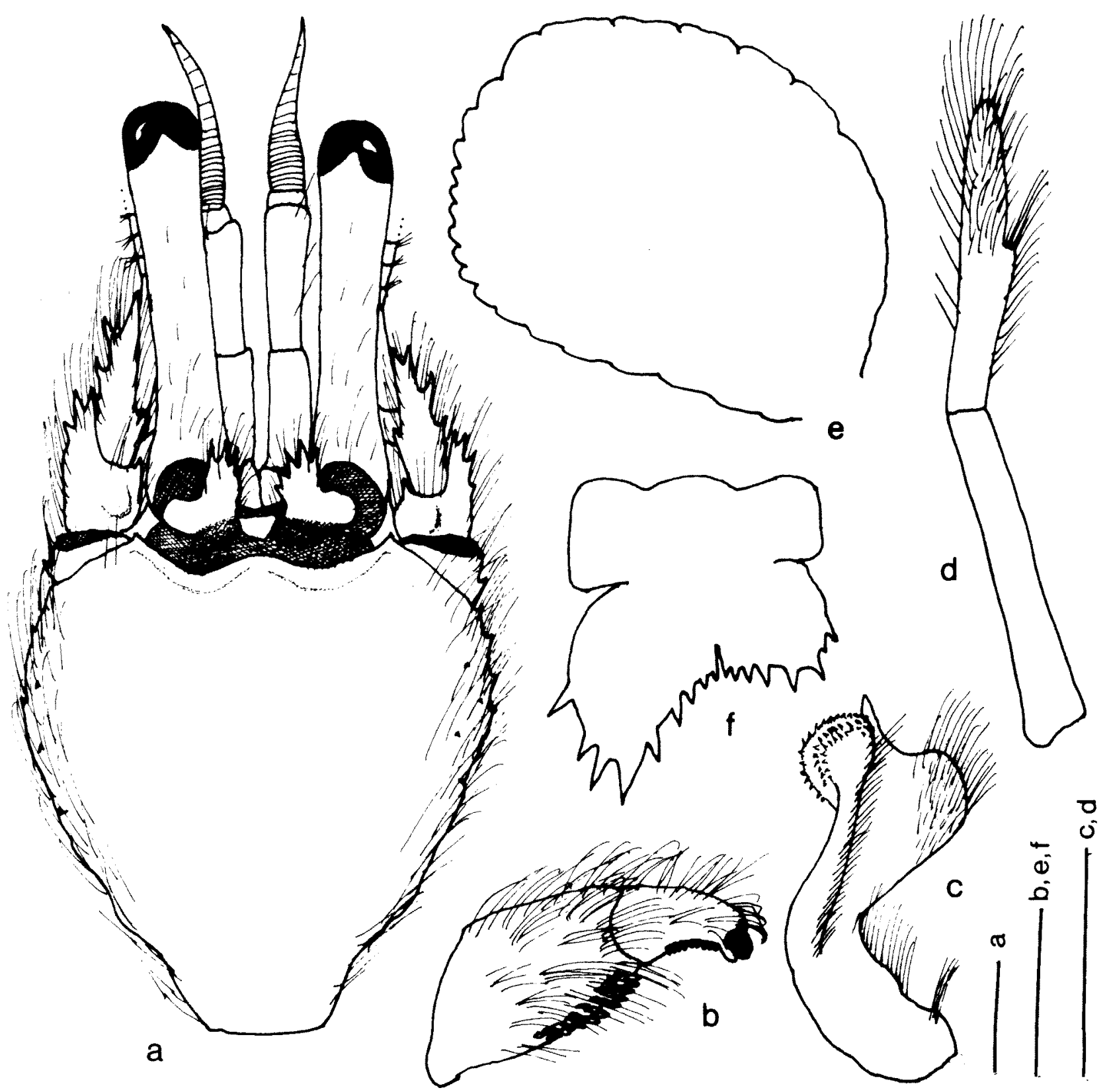

Figure 16 Paguristes dampierensis sp. nov., a, c, d, f, male paratype $(3.8 \mathrm{~mm})$, b, e, ovig. female paratype $(4.2 \mathrm{~mm})$ (WAM C 25933). a, shield and cephalic appendages (aesthetascs omitted); $\mathbf{b}$, dactyl and propodus of right fourth pereopod (lateral view); c, male right first pleopod; d, male right second pleopod; e, female brood pouch; $f$, telson (setae omitted). Scales equal $2 \mathrm{~mm}(\mathrm{~b}, \mathrm{e})$ and $1 \mathrm{~mm}(\mathrm{a}, \mathrm{c}, \mathrm{d}, \mathrm{f})$.

each with row of tufts of moderately long, pinnate setae; lateral faces each with longitudinal row of sparse tufts of short setae dorsally; mesial faces each with longitudinal sulcus, flanked dorsally by row of very small, minutely corneous-tipped, tuberculate spines on second pereopods or tufts of short and long, pinnate setae on third, ventromesial margins, particularly of second pereopods, each cut by row of short transverse ridges accompanied by long and short pinnate setae; ventral margins each with row of 20-25 minute corneous spines. Propodi 1.2-1.3 length of carpi; dorsal margins each with row of spines accompanied by tufts of moderately long, pinnate setae (second), or only tufts of moderately long, pinnate setae sometimes arising from low protuberances (third); mesial faces of second pereopods each with prominent longitudinal sulcus, flanked ventrally by row of transverse denticulate or spinulose ridges and moderately long, pinnate setae, mesial faces of third convex, each with row of moderately long, pinnate setae dorsally, faint transverse, unarmed ridges and moderately long, pinnate setae, extending onto ventral margin; lateral surfaces each with median longitudinal row of long 


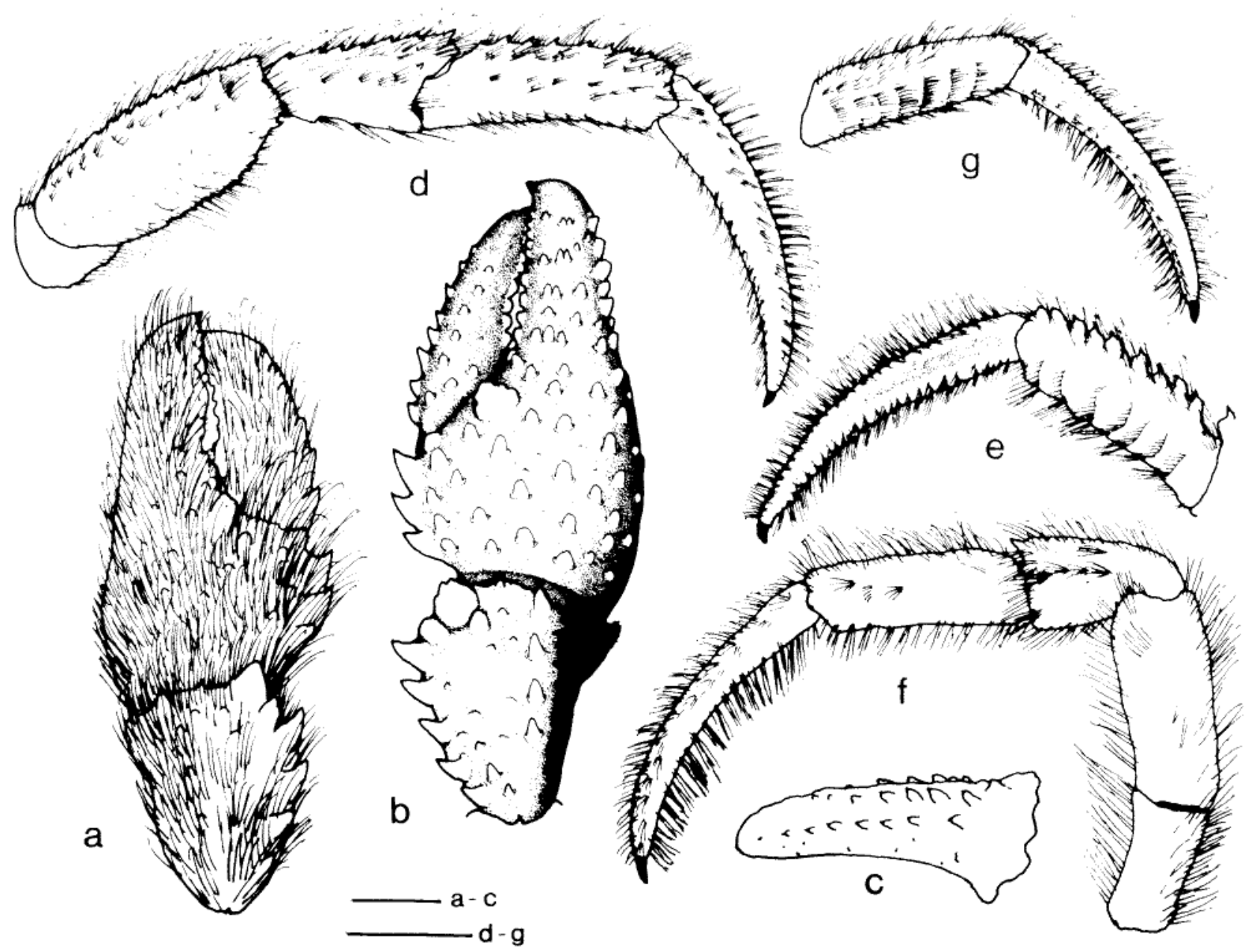

Figure 17 Paguristes dampierensis sp. nov., male paratype $(3.8 \mathrm{~mm}$ ) (WAM C 25933). a, chela and carpus of left cheliped (dorsal view, setal density not precise); $\mathbf{b}$, chela and carpus of right cheliped (dorsal view, setae omitted); c, dactyl of right chela (mesial view, setae omitted); d, right second pereopod (lateral view); $\mathbf{e}$, dactyl and propodus of right second pereopod (mesial view); $f$, left third pereopod (lateral view); $g$, dactyl and propodus of left third pereopod (mesial view). Scales equal $2 \mathrm{~mm}(\mathrm{~d}-\mathrm{g})$ and $1 \mathrm{~mm}(\mathrm{a}-\mathrm{c})$.

and short, simple and pinnate setae. Carpi slightly shorter than meri; dorsal margins each with irregular row of moderately small spines (second) or small dorsodistal spine (third); lateral faces each with 2 or 3 longitudinal rows of tufts of short to moderately long, pinnate setae, left also with small spine on distal margin at midlength; ventral surfaces with few tufts of moderately long setae. Meri each with dorsal row of spinulose protuberances or small spines and tufts of moderately long, pinnate setae (second), or small dorsodistal spine and similar tufts of setae (third); ventral margins each with double row of small spines and tufts of moderately long setae, ventrolateral distal angle with small spine (second), or unarmed (third) and with tufts of moderately long, pinnate setae. Ischia each with small dorsodistal spine; ventral margins of second with 2 or 3 widely-spaced spinules, third unarmed, but all with tufts of moderately long, pinnate setae. Fourth pereopods (Figure 16b) each with prominent preungual process at base of claw.
Male first pleopods (Figure 16c) with row of setae on lateral margin of basal lobe; inferior lamella with row of setae on lateral margin, distal margin with 3 rows of curved spines extending considerable distance along free inner margin; internal lobe moderately small, with row of long setae on mesial margin and numerous moderately long setae on inferior face; external lobe extending little bevond distal margin of inferior lamella. Second pleopods (Figure 16d) with elongate naked basal segments; endopods each with row of fine setae on inner margin and tuft of longer setae terminally; appendix masculina with long marginal setae and shorter setae on inner and outer surfaces. Left pleopods 3-5 uniramous, with long marginal setae. Female gonopores paired; paired first pleopods well developed. Brood pouch (Figure 16e) varying from elongate and moderately broad to broadly subcircular with weakly scalloped margins and fringe of setae, completely enclosing eggs carried on pleopods $2-4$. Non-eyed eggs measuring between 0.9 and $1.1 \mathrm{~mm}$ in diameter. 
Telson (Figure 16f) with deep lateral incisions separating anterior and posterior lobes; asymmetrical posterior lobes separated by very shallow, slit-like median cleft; left lobe usually appreciably elongate, subtriangular with rounded apex, terminal margin with row of spines, increasing in size toward outer angle, continued onto lateral margin, and not concealed by accompanying long setae; right lobe with terminal margin slightly oblique, with row of spines, also increasing in size toward outer angle, extending onto lateral margin, and accompanied by long setae.

\section{Colour (in preservative)}

Most color lost; however, ocular peduncles uniformly orange except for large white patch dorsally at base of each cornea.

\section{Habitat}

Substrates of rock, rubble, coarse and muddy sand.

\section{Distribution \\ Dampier Archipelago, Western Australia; 36-55 $\mathrm{m}$.}

\section{Etymology}

The specific name derived from the type locality, the Dampier Archipelago of Western Australia.

\section{Affinities}

Paguristes dampierensis, $\mathrm{sp}$. nov. is most closely allied to Paguristes brevirostris Baker, 1905, from southwestern Australia, sharing with the latter species a markedly reduced rostrum, multispinose ocular acicles and prominent sculpturing of the ventromesial margins of the propodi of the second pereopods. The two species are immediately separable by the armament of the mesial faces of the dactyls of the chelipeds. These surfaces in $P$. dampierensis (Figure $17 \mathrm{c}$ ) are armed with one row of prominent spines or spinulose tubercles, with a second shorter row dorsally. These surfaces in $P$. brevirostris have a scattering of small tubercles (Figure 18c). Additionally, setation on the chelipeds and ambulatory legs is much more abundant in $P$. dampierensis, the chelas and carpi each usually have one tuberculate spine that is much more prominent than the remainder on the dorsal surfaces, the inferior lamella of the male first gonopod has only three rows of spines on the distal margin, and the terminal margins of the telson are armed with a row of large spines on each lobe.

In having one enlarged tuberculate spine on the dorsal surface of the carpus of each cheliped near the distal margin, $P$. dampierensis sp. nov. is superficially similar to $P$. pugil. However, the mesial faces of the dactyls of $P$. pugil, like those of
$P$. brevirostris, have numerous scattered small spines that do not form one or two distinct rows. Additionally, the tubercles on the dorsal surfaces of the chelas of $P$. pugil are flattened and squamiform, the rostrum is well developed, and the inferior lamella of the male first pleopod has a single row of hooked spines on the distal margin.

\section{Remarks}

The larvae of the ovigerous female collected in a grab sample northwest of Cape Legendre were sufficiently close to eclosion that two individuals did prematurely hatch when the specimen was preserved. Unlike the premature eclosion described by Konishi and Imafuku (2000) for the pylochelid, Pomatocheles jeffreysii Miers, 1879, the two larvae of $P$. dampierensis sp. nov. were not encapsulated in prezoeal cuticles. Although not as advanced in development as that described for larvae of $P$. abbreviatus Dechancé, 1963a, by Dechancé (1963b) or for $P$. frontalis, as described by Morgan (1987b), both of which hatch as megalopae, the hatchlings of $P$. dampierensis exhibited a mixture of zoeal and megalopal features. Development of the ocular peduncles was, for example, as advanced as seen in megalopa of $P$. sericeus A. Milne-Edwards, 1880 (cf. Rice and Provenzano, 1978: figs 1b, f) that followed two zoeal stages, or $P$. ortmanni Miyake, 1978 (cf. Quintana and Iwata, 1987, fig. 2D) that followed three zoeal stages. The antennular peduncles of $P$. dampierensis consisted of three segments, with moderately well developed but apparently unsegmented buds of the upper and lower rami; only three or four short terminal setae were present on the upper ramus. The antennae showed signs of weak segmentation, with the exopods moderately elongate as was described for the megalopa of $P$. emerita (Linnaeus, 1767) by Pike and Williamson [1960, as P. oculatus (Fabricius, 1775)]. The mouthparts, although all lacking setae, were also of megalopal form. The thoracic appendages were completely segmented, with the most advance development seen in the propodi and dactyls of the fifth and fourth pereopods. Gill development was comparable to that seen in many megalopae. In contrast, the six-segmented pleon carried only naked, undifferentiated, uniramous buds on somites $2-5$. The biramous uropods of somite 6 , also lacking setae, were similar in relative size to those of zoeal stage 3 of $P$. emerita (cf. Pike and Williamson, 1960: fig. 4C), but the endopods and exopods were not distinctly articulated with the protopods. The telson was zoeal in general shape, with a distinct median cleft. However, no anomuran hair could be distinguished, or was the outermost process spine-like. Instead, each posterior lobe was provided with 12 or 13 articulated, stiff, hair-like processes, more numerous, but similar to those illustrated by 
Dechance (1963b: fig. 12) for the megalopa of $P$. abbreviatus and Morgan (1987b, fig. $1 \mathrm{~g}$ ) for the megalopa of $P$. frontalis. Clearly, larval development is very abbreviated in $P$. dampierensis, but it is not yet possible to say whether metamorphosis occurs prior to or very shortly after eclosion.

\section{Paguristes brevirostris Baker, 1905}

Figure 18

Paguristes brevirostris Baker, 1905: 256, pl. 33, fig. 1, 1a. - Hale, 1927a: 91, fig. 86. - Anderson, 1938: 351. - Gordan, 1956: 321 (literature). - Morgan, 1987c: 733 (key). - Davie, 2002: 54.

Paguristes brevirostrus. - Mower and Shepherd, 1988: 84 (misspelling of brevirostris).

\section{Material examined}

\section{Syntypes}

Southeast Australia. SAMA C 291 (3 males, 5.8$8.3 \mathrm{~mm}$; 1 female, $4.8 \mathrm{~mm}$, eggs recently hatched as megalopas; 6 preserved with syntypes), SE Australia.

\section{Other material examined}

Victoria. NMV J 11363 (1 male, $2.6 \mathrm{~mm} ; 3$ females, 2.5-2.6 mm; 1 ovig. female, $2.3 \mathrm{~mm}$ ), Western Port $\left(38^{\circ} 29^{\prime} \mathrm{S}, 1^{\circ} 5^{\circ} 02^{\prime} \mathrm{E}\right)$. South Australia. NMV J 11195 (1 female, $6.8 \mathrm{~mm}$ ), Investigator Str.; NMV J 11324 (1 male, $6.1 \mathrm{~mm} ; 1$ ovig. female, $6.4 \mathrm{~mm}$ ), off Port Lincoln; NMV J 27590 (1 male, $6.0 \mathrm{~mm}$ ) and NMV J 20515 (1 male, $3.4 \mathrm{~mm}$ ), Tumby Bay (3422's, $136^{\circ} 08^{\prime} \mathrm{E}$ ); SAMA PC 0321 (1 male, $3.6 \mathrm{~mm}$ ), Yorke Pen., Edithburgh, 3-4 m, coll. K. Gowlett-Holmes, 09.05.1999; SAMA PC 0324 (1 male, $6.6 \mathrm{~mm}$ ), Yorke Pen., Edithburgh, 3-4 m, coll. K. Gowlett-Holmes, 11.12.2004.

\section{Abbreviated description}

Gills biserial. Shield (Figure 18a) appreciably longer than broad; dorsal surface with few small spines marginally and/or laterally, and few tufts of moderately short setae. Lateral projections broadly triangular, subacute or rounded, with or without terminal spinule. Rostrum very broadly triangular, reaching approximately to level of lateral projections, unarmed or in one syntype minutely denticulate; anterior margin with few setae. Branchiostegites with unarmed but sparsely setose dorsal margins; anterior margins with moderately dense setae. Ocular peduncles $0.6-0.8$ length of shield; dorsal surface with few sparse tufts of setae; corneal diameter 0.2-0.3 of peduncular length. Ocular acicles subrectangular to subtriangular; terminal margins horizontal or oblique each with $2-$ 6 moderately large spines. Antennular peduncles when fully extended reaching beyond basal margins but not beyond distal margins of corneas. Ultimate and penultimate segments with few moderately short setae. Basal segment with 1 small spine on dorsolateral margin of statocyst lobe, 1 or 2 slightly larger spines on laterodistal margin and 1 prominent spine at ventromesial distal angle. Antennal peduncles reaching slightly beyond midlength of ocular peduncles; fourth segment with dorsodistal spine; third segment with prominent ventrodistal spine; second segment with dorsolateral distal angle produced, terminating in bifid spine, 1 or 2 spines on lateral margin distally and occasionally 1 much smaller spine proximally; dorsomesial distal angle with prominent spine and occasionally small spine on mesial face; first segment with blunt or acute small spine at laterodistal margin; ventrolateral margin unarmed. Antennal acicle reaching beyond midlength of ultimate peduncular segment but not reaching to distal margin, with prominent bifid terminal spine; mesial margin with 1 or 2 spines in proximal half, lateral margin with 1 or 2 spines in distal half. Antennal flagellum shorter than carapace; each article with 3-5 moderately long and often 1 or 2 shorter, randomly-set setae.

Chelipeds subequal; left (Figure 18b) slightly larger; armature generally similar; dactyls and fixed fingers often with small hiatus. Dorsomesial margins of dactyls each with row of low tubercles or tuberculate spines dorsal surfaces occasionally with 1 similar, adjacent row of tuberculate spines in proximal half and/or few tubercles proximally, each accompanied by sparse tuft of setae; mesial faces (Figure 18c) each with irregular rows of small flattened tubercles. Palms each with row of 3 or 4 prominent, usually subacute spines and sparse tufts of setae on dorsomesial margin, dorsolateral margin not delimited; generally flat dorsal surface with numerous, usually smaller tuberculate spines, each accompanied by sparse tuft of setae, 2 or 3 irregular rows extending nearly entire length of fixed finger; lateral face with numerous tuberculate spines or simple tubercles each accompanied by sparse tuft of setae; mesial and ventral surfaces with few scattered low tubercles or protuberances and spare setae. Carpi each with row of 5 moderate to large, acute or subacute spines on dorsomesial margin, dorsal surface with scattered, tubercles or tuberculate spines, each usually accompanied by tuft of sparse setae, densest on dorsomesial margin; mesial face with row of protuberances and sparse setae; lateral face with few low protuberances becoming spinose at distal angle. Meri each with 1 or 2 corneoustipped small spines on dorsodistal margin, spines continued onto distal margins mesially and laterally; dorsal margin with 2 subdistal ridges, each with small, corneous-tipped spine, proximal 0.6 of dorsal margin with short, transverse ridges accompanied by sparse setae; ventromesial margin 


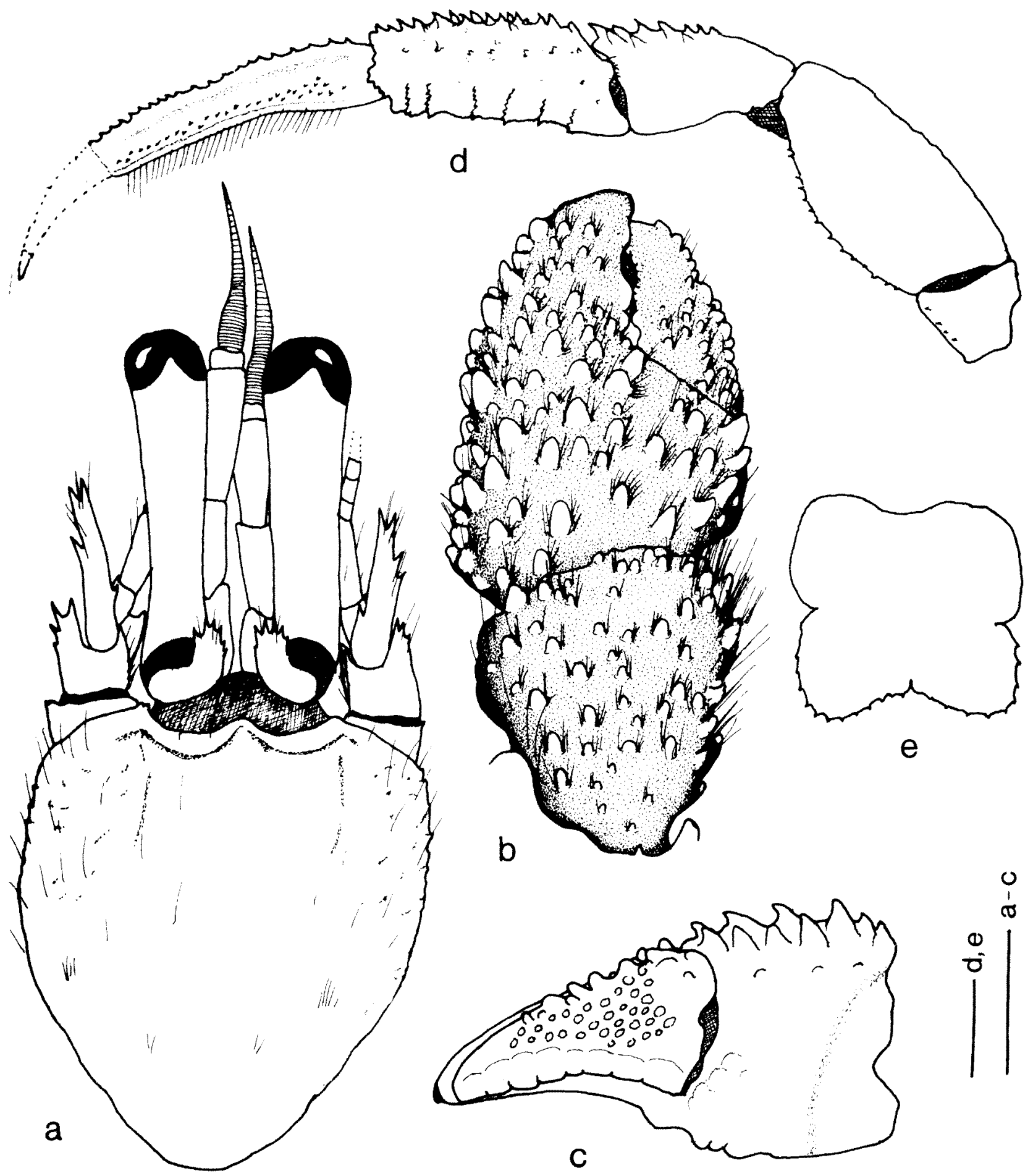

Figure 18 Paguristes brevirostris Baker, 1905, male syntype $(7.5 \mathrm{~mm})$ (SAMA C 291). a, shield and cephalic appendages (aesthetascs omitted); $\mathbf{b}$, chela and carpus of left cheliped (dorsal view); $\mathbf{c}$, right chela (mesial view); $d$, right second pereopod (mesial view, most setae omitted); e, telson (setae omitted). Scales equal $2 \mathrm{~mm}(\mathrm{a}-\mathrm{d}$ ) and $1 \mathrm{~mm}(\mathrm{e})$.

with irregular row of small, usually blunt tuberculate spines or spinules; ventrolateral margin with row of larger, usually subacute spines and sparse setae.

Second (Figure 18d) and third pereopods with dactyls 1.2-1.5 length of propodi; dorsal margins each with row of small, corneous-tipped acute spines, appreciably smaller on third, and 1 or 2 irregular rows of long simple setae; lateral faces each with weak longitudinal sulcus, at least proximally, and row of moderate to widely-spaced tufts of sparse simple setae; mesial faces each with longitudinal sulcus, irregular single to double row of minute, corneous spinules; moderately broad ventral surfaces each with 2 or 3 longitudinal rows of long simple setae. Propodi each with single to 
double row of corneous-tipped spines on dorsal margin accompanied by tufts of moderately long, simple or occasionally distally pinnate or plumose setae (second), or only tufts of moderately long, simple or occasionally distally pinnate or plumose setae arising from low protuberances (third); ventral and mesial faces ventrally each cut by series of transverse, distally spinulose ridges, weaker and frequently unarmed on third, dorsal half with 1 or occasionally 2 rows of low, often spinulose tubercles or protuberances and moderately long, simple setae (second) or only tufts of setae (third), distal margins each with few small, spinulose tubercles or tuberculate spines; lateral surfaces each with median longitudinal row of long and short, simple and pinnate setae. Carpi each with irregular single or double row of often comeous-tipped spines on dorsal margins accompanied by tufts of moderately long, simple, distally pinnate or plumose setae (second) or dorsodistal spine and few low protuberances and tufts of similar setae (third); lateral faces each with prominent longitudinal sulcus lined with tufts of moderately long, simple and occasionally distally pinnate or plumose setae, usually 1 additional row of tufts of sparse similar setae ventrally; mesial faces each with 2 or 3 spinules or small spines on distal margin dorsally, ventral surfaces each with moderately dense simple or plumose setae on distal margin. Meri each with dorsal row of low, occasionally spinulose protuberances and tufts of moderately long, simple and occasionally distally pinnate or plumose setae (second), or simply low protuberances and tufts of similar setae; ventral margins each with double row of small spines or tiny spinules and tufts of moderately long setae (second) or only tufts of setae (third), ventrolateral distal angle usually with 1 or 2 small, often blunt spines.

Male first pleopod with tuft of setae on lateral margin of basal lobe; inferior lamella with row of setae on lateral margin, distal margin with 4 rows of tiny spines extending considerable distance along free inner margin; internal lobe moderately small, with irregular row of long setae on mesial margin; external lobe extending little if at all beyond distal margin of inferior lamella. Second pleopod with elongate naked basal segment; endopod with row of setae on inner margin and tuft of longer setae terminally; appendix masculina with long marginal setae and shorter setae on inner and outer surfaces. Left pleopods 3-5 uniramous, with long marginal setae. Female brood pouch elongate, moderately broad.

Telson (Figure 18e) with deep lateral incisions separating anterior and posterior lobes; slightly asymmetrical posterior lobes separated by very shallow, slit-like median cleft; lobes both subtriangular with rounded apices, terminal margins each with row of small to minute spines, continued onto lateral margin, and not concealed by accompanying long setae.

\section{Colour (in life)}

Ocular and antennular peduncles reddish brown; chelipeds appearing white because of particulate matter caught in setae, but with patches of brown proximally on carpi; dactyls of ambulatory legs light brown in proximal halves (from photo by $K$. Gowlett-Holmes). In preservative, ocular and antennular peduncles and ultimate segments of antennal peduncles orange. Chelipeds white with faint orange tint to cutting edges of dactyls and fixed fingers and streak of orange at articulation of dactyl and palm; patches of orange proximally on carpi, meri with orange tint. Ambulatory legs with dactyls light orange in proximal halves; propodi, carpi and meri mottled orange and white, particularly on lateral faces and dorsal surfaces proximally.

\section{Habitat}

Sand substrate.

\section{Distribution}

Southeastern Australia; 3-55 m.

\section{Affinities}

As previously indicated, $P$. brevirostris is most closely allied to $P$. dampierensis, but is also similar to $P$. longisetosus. In addition to the differentiating characters discussed above, the spination of the telson appears diagnostic. The terminal margins of the telson in $P$. brevirostris and $P$. longisetosus are provided with only spinules or very small spines, whereas these margins are armed with fewer but much more prominent spines in $P$. dampierensis

\section{Remarks}

Although larval development in $P$. brevirostris has not been investigated, the fact that the ovigerous female syntype was found with eggs hatched at the megalopal stage indicates that development in this species is abbreviated as it is in P. frontalis (Morgan, 1987b).

\section{Paguristes longisetosus Morgan, 1987d} Figure 19

Paguristes longisetosus Morgan, 1987d: 726, fig. 1. Morgan, 1989: 393. - Davie, 2002: 55.

\section{Holotype}

Western Australia. WAM C 16858 (male, 7.3 $\mathrm{mm}$ ). Two Mile Beach, E of Hopetoun (33 56'14"S, 120\%10'04"E), coll. G. Morgan, 28.11.1985 (not seen). 


\section{Material examined}

Tasmania. NMV J 52822 (1 male, $2.5 \mathrm{~mm}), 65 \mathrm{~km}$ ENE Cape Rochon $\left(40^{\circ} 10.54 \mathrm{~S}, 116^{\circ} 44.18^{\prime} \mathrm{E}\right), 55 \mathrm{~m}$. South Australia. NMV J 27601 (1 ovig. female, 3.8 mm), Pt Sinclair; SAMA C 17096 (2 males, 7.6,9.5 $\mathrm{mm})$, Yorke Pen., Port Victoria, $3-5 \mathrm{~m}$, coll. $\mathrm{W}$. Zeidler and K. Gowlet-Holmes, 17.03.1994; WAM C 16518 ( 2 females, 2.7, $3.0 \mathrm{~mm}$ ), Ceduna, coll. E. Ride, 01.01.1971. Western Australia. WAM C 18072 (2 males, 3.9, $5.5 \mathrm{~mm}$; female, $4.6 \mathrm{~mm}$ ), Quaranup jetty, Albany $\left(35^{\circ} 58^{\prime} S, 117^{\circ} 58^{\prime} \mathrm{E}\right)$, coll. G. Morgan, 14.01.1988; WAM C 18046 (1 male, 4.4 mm; 1 female, $3.0 \mathrm{~mm}$ ), Princess Royal Harbour, Albany (345' ${ }^{\circ}$, $\left.117^{\circ} 58^{\prime} \mathrm{E}\right)$, coll. G. Morgan, 26.01.1988; NMV J 20519 (1 male, $5.0 \mathrm{~mm}$ ), Frenchman's Bay

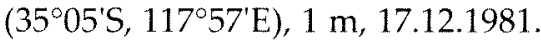

\section{Abbreviated description}

Gills biserial. Shield (Figure 19a) longer than broad; dorsal surface with scattered small spines or spinules laterally and moderately dense setae. Rostrum triangular, reaching proximal $0.3-0.5$ of ocular acicles; terminating acutely or with 1 or 2 minute spinules. Lateral projections triangular, each usually with small marginal spine. Branchiostegites each with short row of very small spines on dorsal margin anteriorly and 1 to few on distal margin. Ocular peduncles moderately stout, $0.6-0.7$ shield length, dorsomesial surfaces each with row of tufts of sparse setae at least proximally; corneal diameter $0.2-0.3$ of peduncular length. Ocular acicles each bior multifid. Antennular peduncles reaching from bases of corneas to corneal margins. Ultimate and penultimate segments unarmed; basal segment with ventromesial distal angle produced, terminating in small spine; lateral face with 2-4 small spines dorsally. Antennal peduncles reaching from distal 0.5 of ocular peduncles to bases of corneas; fourth segment with spine at dorsodistal margin; third segment with ventromesial distal angle prominently produced, terminating in acute spine; second segment with dorsolateral distal angle produced, terminating in bifid spine, lateral margins unarmed or with 1-3 small spines; dorsomesial distal angle with 1-3 small spines; first segment with ventral margin produced and 1-3 tiny spinules dorsolaterally. Antennal acicles reaching distal $0.5-0.6$ of ocular peduncles, terminating in bifid spine, mesial margins each with 1 or 2 moderately large spines proximally; lateral margins unarmed or with 1 or 2 spines distally. Antennal flagella very short, approximately equal to length of shield; articles each with several moderately short setae.

Chelipeds subequal, left (Figure 19b) usually slightly larger; similar in armature. Dorsomesial margin of dactyl with row of moderately small to moderately large, often corneous-tipped, spines decreasing in size distally, and with scattered long setae; dorsal surface with few to numerous smaller spinulose tubercles; mesial surface (Figure 19c) with 3-5 irregular rows of moderately large, sometimes corneous-tipped tubercles, largest along ventral margin, and tufts of long setae; cutting edge with row of calcareous teeth in proximal 0.5-0.6, replaced by corneous teeth distally. Palm with 3 or 4 prominent, often corneous-tipped spines and long setae on dorsomesial margin; dorsal surface with several irregular rows of small to moderately large spines, extending nearly to tip of fixed finger; mesial surface with few low protuberances near dorsomesial margin, dorsolateral margin not delimited; cutting edge of fixed finger with row of moderately large calcareous teeth. Carpus with 4 or 5 large spines on dorsomesial margin, dorsal surface with scattered smaller spines or tubercles, 1 large and few smaller spines on distal margin, dorsolateral margin not distinctly delimited. Merus with few spines on distal margin dorsally and dorsal margin distally; ventrolateral and ventromesial margins each with row of small spines or spinulose tubercles.

Second (Figure 19d) and third pereopods with dactyls longer than propodi. Dactyls each with row of small, corneous-tipped spines becoming simple corneous spines distally, most prominent on second pereopods, and accompanied by tufts of long setae; lateral surfaces each with longitudinal sulcus proximally and row of tufts of setae; mesial faces each with longitudinal sulcus proximally and scattered low protuberances and tufts of long setae, most numerous ventrally and on second pereopods; ventral margins each with row of 20-25 corneous spines partially obscured by tufts of long setae. Propodi each with row of corneous-tipped spines (second pereopods) or low protuberances (third pereopods) on dorsal surface accompanied by tufts of long setae; mesial faces each with scattered spinules or spinulose protuberances and tufts of long setae; ventral surfaces each cut by row of weak spinulose scutes lined with long setae, faintest on third pereopods. Carpi each with row of moderately large spines and tufts of long setae on dorsal surface of second pereopods, dorsodistal spine and low, sometimes spinulose protuberances or very small spines on third. Meri each with row of small spines or spinulose protuberances and tufts of setae on dorsal and ventral margins. Fourth pereopods each with preungual process at base of claw.

Male first pleopod with tuft of long setae on mesiodistal angle of basal segment. Inferior lamella with row of setae on outer (lateral) margin, few setae proximally; distal margin broadly rounded, armed with 2 rows of prominent, outwardly curved, corneous spines. External lobe terminating subacutely, reaching to distal margin of inferior lamella. Internal lobe subovate, mesial margin with 


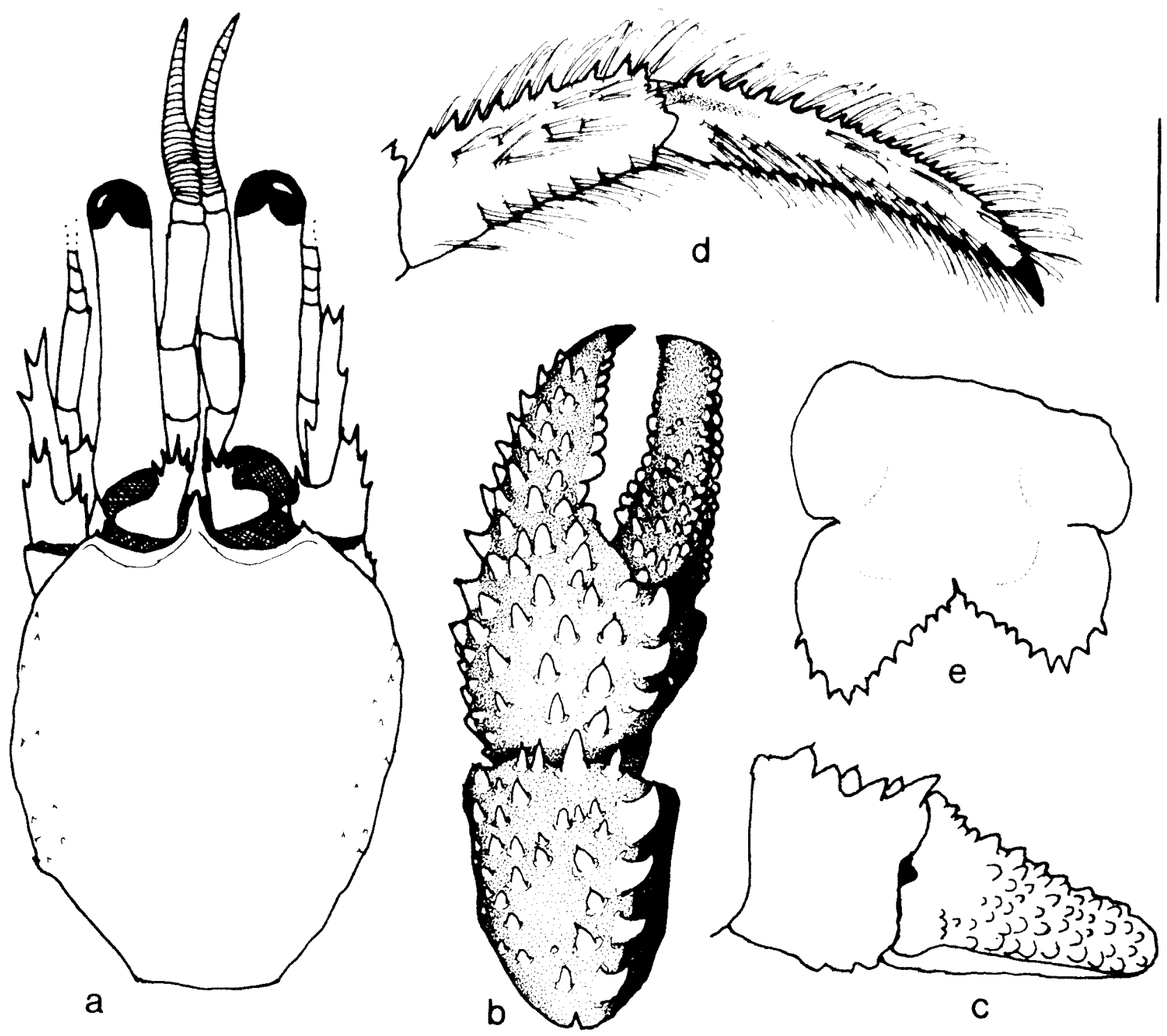

Figure 19 Paguristes longisetosus Morgan, 1987d, male $(5.5 \mathrm{~mm}$ ) (WAM C18072). a, shield and cephalic appendages (aesthetascs and setae omitted); $\mathbf{b}$, chela and carpus of left cheliped (dorsal view, setae omitted); $\mathbf{c}$, left chela (mesial view, setae omitted); $\mathbf{d}$, dactyl and propodus of left second pereopod (mesial view); $\mathbf{e}$, telson (setae omitted). Scale equals $2 \mathrm{~mm}$ (a-d) and $1 \mathrm{~mm}$ (e).

row of long setae. Female with paired gonopores; brood pouch subquadrate.

Telson (Figure 19e) with posterior lobes asymmetrical, separated by shallow median cleft, each lobe subtriangular with subacute to rounded apex, terminal margins each with row of moderately small spines, extending onto lateral margins.

\section{Colour}

"Shield pale brown with setal pores cream or white and darker red-brown patches, especially along midline and midlaterally. Ocular peduncles and acicles pale brown, darker proximally; corneas black. Antennular and antennal peduncles and flagella red-brown. Chelipeds pale brown with white spines and tubercles; some red patches on carpi and meri. Pereopods red or red-brown, with white patches at setal bases forming irregular dorsal, lateral and ventral rows. Setae pale yellow or yellow-brown" (Morgan, 1987d).

\section{Habitat}

Usually shallow sublittoral in rocks and sand, occasionally considerably deeper; $1-55 \mathrm{~m}$.

\section{Distribution}

Tasmania, South Australia and Western Australia.

\section{Affinities}

As previously indicated, $P$. longisetosus appears closely allied to $P$. puniceus. In addition to the differences in the ocular acicles of the two species, a suite of characters can be used to separate the 
two taxa. In $P$. puniceus Mclaughlin (2004b) found the antennular peduncles always overreached the distal margins of the corneas. In the specimens of $P$. longisetosus available, the antennular peduncles were consistently shorter, rarely even reaching the distal corneal margins. The dorsal margins of the dactyls of the second pereopods of $P$. puniceus were armed proximally with a few to several small spines, the number increasing in larger specimens. These margins in $P$. longisetosus are armed over their entire lengths. The inferior lamella of the male first pleopod has a double row of hooked spines in $P$. longisetosus, but a single row in $P$. puniceus. However, variations in the armature of the male first gonopods have not been investigated.

\section{Remarks}

In his original description of $P$. longisetosus, Morgan (1987d) differentiated it only from the three other species of Paguristes reported from southern Australia. As noted by Morgan, the spinose armature of the chelipeds of $P$. Iongisetosus immediately sets this species apart from $P$. squamosus and $P$. pugil, species in which the chelipeds are armed with squamiform tubercles. The density of the setation that conceals the armature in $P$. sulcatus distinguishes that species from $P$. longisetosus. At the time of its original description, the distribution of $P$. longisetosus was thought to be restricted to southern Western Australia; however, lots examined during the current investigation have shown that the range of this species includes western South Australia and the Bass Strait as well.

Although the usually distinct differences in rostral length should differentiate $P$. longisetosus from $P$. brevirostris, this is not always the case, and the two species have been confounded in the collections of Museum Victoria. The two species share somewhat similar armature of the mesial faces of the dactyls of the ambulatory legs and the general armature of the mesial faces of the dactyls of the chelipeds. However, the dactyls of the second and third pereopods of $P$. longisetosus are shorter and the ventromesial margins of the dactyls of the chelipeds in this species have only a row of moderately large, individual tuberculate spines. The ventromesial margins of the dactyls of the chelipeds of $P$. brevirostris are armed with a row of flattened plate-like tubercles. Additionally, the mesial faces of the ambulatory propodi appear more rugose in $P$. longisetosus. Both species have a moderate to abundant amount of setae on the dorsal surfaces of the chelas that do not obscure the surface armature, but these setae are usually appreciably longer in $P$. longisetosus as its specific epithet implies. The occurrences of $P$. longisetosus in South Australia and Tasmania have considerably expanded the eastward distribution and depth ranges of this species.

\section{Paguristes sulcatus Baker, 1905 Figure 20}

Paguristes sulcatus Baker, 1905: 258, pl. 34, fig. 1, 1a. - Hale, 1927a: 90, fig. 85. - Hale, 1927b: 310. Gordan, 1956: 324 (literature). - Morgan, 1987d: 733 (key). - Mower and Shepherd, 1988: 84. Morgan, 1989: 395, fig. 1a.--Morgan and Forest, 1991b: 108, fig. 1b, d, f. - Jones and Morgan, 1993: 169 (list). - Davie, 2002: 56.

? Paguristes barbatus. - Lucas, 1886: 62. Not Paguristes barbatus (Heller, 1862).

\section{Material examined}

\section{Syntypes}

South Australia. 3 apparent females (6.2, 8.0, 8.2 mm) (SAMA C 927), Port Willunga, South Australia, littoral.

\section{Other material examined}

Victoria. NMV J 11382 (1 male, $6.2 \mathrm{~mm}$ ), Western Port; NMV J 11350, (1 male, $8.1 \mathrm{~mm})$, Western Port, Honeysuckle Point $\left(38^{\circ} 26^{\prime} \mathrm{S}, 145^{\circ} 04^{\prime} \mathrm{E}\right)$; NMV J 17862 (1 male, $3.7 \mathrm{~mm}$ ), West Head (38 $29^{\prime} \mathrm{S} 145^{\circ} 02^{\prime} \mathrm{E}$ ); NMV J 17425 (2 males, 4.0, 4.4 mm), Wilson's Promontory, Refuge Cove $\left(39^{\circ} 02.18^{\prime} \mathrm{S}, 146^{\circ} 27.54^{\prime} \mathrm{E}\right)$; NMV J 11377 (1 male, .7 mm), Wilson's Promontory, $2.5 \mathrm{~km} \mathrm{~N}$ of South East Point (39 06.36'S, $\left.146^{\circ} 25.36^{\prime} \mathrm{E}\right)$. Western Australia. WAM C 17419 (2 males, 5.7, $13.7 \mathrm{~mm}$ ), reef off Little Armstrong Bay, Rottnest I. (35 59'25'S, 115 $\left.30^{\prime} 20^{\prime \prime} \mathrm{E}\right)$, 0-3 m, 14.02.1985; WAM C 7646 (1 male, $13.2 \mathrm{~mm} ; 1$ female, $11.4 \mathrm{~mm}$ ), Yanchep Reef, $30 \mathrm{mls} \mathrm{N}$ of Perth, 15.03.1959; WAM C 18107 (5 males, 9.2-16.7 mm, 2 females, $7.4,8.5 \mathrm{~mm}$; 1 ovig. female, $8.8 \mathrm{~mm}$ ), Ledge

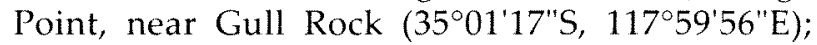
WAM C 18108 (5 males, 9.4-13.7 mm; 2 ovig. females, 9.6, $12.4 \mathrm{~mm}$ ) inside Mistaken I., near

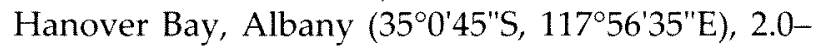
$3.0 \mathrm{~m}, 03.12 .1985$.

\section{Abbreviated description}

Gills biserial; dorsal margins of branchiostegites each with few tiny spinules distally and 1 or 2 on anterior margin. Shield (Figure 20a) considerably longer than broad; surface rugose and with few spinulose tubercles or small spines laterally, partially obscured by long setae. Rostrum acutely triangular, extending well beyond level of lateral projections and frequently reaching to or slightly beyond midlength of ocular acicles, terminally acute or subacute. Lateral projections obtusely triangular, each usually with 1 or 2 well developed, marginal or submarginal spines. Ocular peduncles 


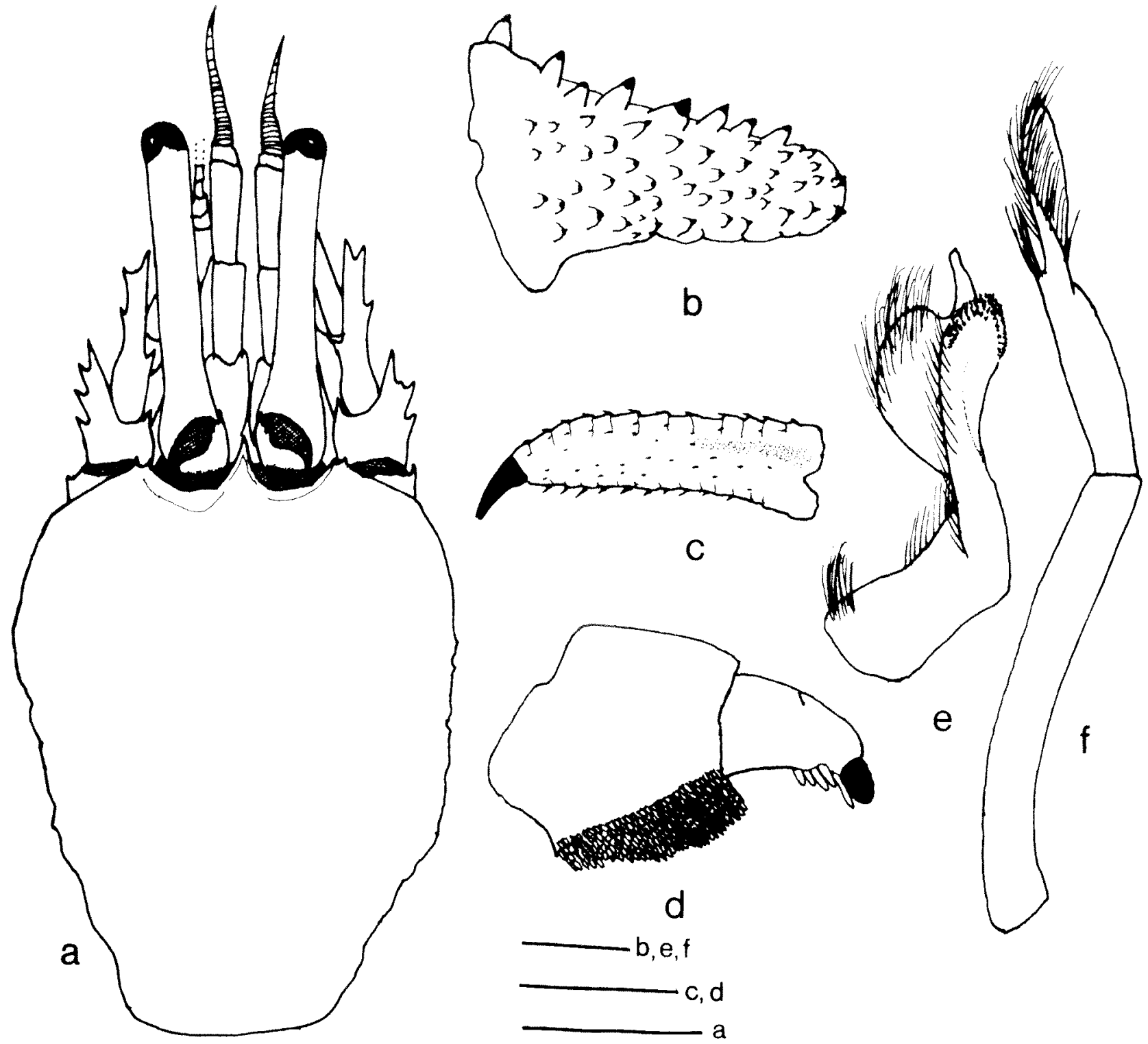

Figure 20 Paguristes sulcatus Baker, 1905, a, c, d, male $(9.4 \mathrm{~mm})$; b, e, f, male (13.6 mm) (WAM C 18108). a, shield and cephalic appendages (aesthetascs and setae omitted); $\mathbf{b}$, dactyl of left chela (mesial view, setae omitted); $\mathbf{c}$, dactyl of right second pereopod (mesial view, setae omitted); d, dactyl and propodus of right fourth pereopod (lateral view, setae omitted); e, male left first pleopod; $f$ male left second pleopod. Scales equal 5 $\mathrm{mm}(\mathrm{a}), 2 \mathrm{~mm}(\mathrm{~b}-\mathrm{d})$ and $1 \mathrm{~mm}(e, t)$.

long and slender, 0.5-0.6 length of shield, each with dense tuft of long setae on dorsal surface proximally; corneal diameter $0.1-0.2$ of peduncular length. Ocular acicles usually terminally bi- or multifid, occasionally simple but often with small accessory spinule, frequently calcified only in distal halves. Antennular peduncles not reaching to slightly overreaching distal margins of corneas; basal segment with acute spine on dorsolateral margin of statocyst lobe. Antennal peduncles reaching distal $0.6-0.9$ of ocular peduncles; fourth segment with dorsodistal spine; third segment with ventrodistal margin drawn out into prominent spine; second segment with dorsolateral distal angle well developed, with bifid terminal spine, usually with 1 or 2 additional spines on lateral margin, dorsomesial distal angle elevated and with prominent spine, margins with long setae; antennal acicle reaching to distal half of fifth peduncular segment, terminally bifurcate, usually with 1 additional spine on lateral margin, 1 or 2 prominent spines on mesial margin, all partially to completely obscured by long setae. Antennal flagellum shorter than carapace, articles each with 2-5 moderate and short setae.

Chelipeds subequal, right sometimes slightly larger, similar in armature; dorsal surfaces of chelas and carpi each with covering of dense tufts of long plumose setae generally obscuring armature. Dactyl with row of comeous-tipped spines on dorsomesial 
margin and few similar spines on dorsal surface in proximal half; mesial face with somewhat irregular or oblique rows of very small, rounded, corneouscapped granules or tubercles increasing in size and becoming corneous-tipped tuberculate spines, at least in largest males (Figure 20b). Palm short, approximately half length of carpus, with 3 prominent, corneous-tipped spines on dorsomesial margin, partially obscured by long setae, dorsal surface of palm and fixed finger with slightly smaller but also corneous-tipped spines; lateral face with covering of spinulose tubercles and tufts of long setae, extending onto ventral surface laterally; cutting edge of fixed finger with corneous teeth distally and few small calcareous teeth proximally, terminating in large corneous claw, no hiatus between dactyls and fixed fingers. Carpus with irregular row of small corneous-tipped spines on dorsolateral margin almost completely concealed by dense long setae, dorsal surface with scattered smaller spines, dorsodistal margin unarmed, dorsomesial margin with row of 4 or 5 prominent, conical, corneous-tipped spines; ventrolateral distal angle with 1 or 2 acute or subacute spines. Merus with row of long, pinnate setae on distal margin; 1 prominent, corneous-tipped spine on dorsodistal margin and second similar spine subdistally; row of small spines on ventromesial margin; ventrolateral margin with row of smaller spines, both accompanied by long setae.

Second and third pereopods with dactyls slightly shorter to approximately equal to propodi in length; dorsal margins each with row of small corneoustipped spines or corneous spinules concealed by tufts of very long pinnate setae; mesial faces (Figure $20 \mathrm{c}$ ) each with longitudinal sulcus in proximal $0.3-$ 0.4 and 2-4 irregular rows of small corneous spinules; ventral surfaces each with row of 9-12 corneous spines also concealed by tufts of long, pinnate setae; lateral faces each with faint longitudinal sulcus and few tufts of very short setae. Propodi each with row of prominent spines at least partially obscured by tufts of long pinnate setae; ventral margins and mesial faces cut by transverse, piliferous ridges, each marginally armed with few corneous spinules and accompanied by tufts of long, pinnate setae; lateral faces each with shallow longitudinal sulcus lined with tufts of moderately short setae. Carpi each with double (second) or single (third) row of prominent, corneous-tipped spines on dorsal surface concealed by tufts of long pinnate setae; lateral faces each with longitudinal sulcus in upper half lined with tufts of pinnate setae. Meri each with tufts of long pinnate on dorsal margins; ventral margins each with row of small spines concealed by dense, long pinnate setae. Ischia each with row of very small spinules on ventral margins, partially concealed by long pinnate setae. Fourth pereopods each with well developed preungual process at base of claw, dactylar rasp consisting of very few scales; propodal rasp (Figure $20 \mathrm{~d}$ ) exceptionally well developed, with several rows of corneous scales.

First male pleopod (Figure 20e) each with tuft of setae at proximomesial angle and row of slightly shorter setae on mesial margin of basal segment; inferior lamella with row of setae on external margin, distal margin with 3-4 irregular rows of small hooked spines; external lobe distinctly overreaching distal margin of inferior lamella, internal lobe short, moderately broad, with long setae marginally and on inner face. Second male pleopod (Figure 20f) with basal segment elongate, naked; distal segment with terminal tuft of setae on endopod, appendix masculina with setae marginally and on inner face. Female brood pouch large and fan-shaped in ovigerous females, completely enclosing eggs attached to pleopods 2-4.

Telson with slightly unequal posterior lobes; roundly triangular terminal margins each with several small spines, sometimes extending slightly onto lateral margins.

\section{Colour (in life)}

"Shield cream and brown mottled. Ocular peduncles pale brown, white near corneas; acicles cream or pale brown; corneas black. Antennular peduncles deep brown-gray with cream near articulations; flagella deep gray-blue. Antennal peduncles cream with brown; flagella distinctly banded in brown and cream, usually alternating wide and narrow brown annuli. Cheliped colors largely obscured by dense setae; all segments primarily pale to medium brown; prominent spines cream or white basally with dark brown corneous tips. Ambulatory legs pale brown and cream; pereopods 4 and 5 very pale. Setae brown." (Morgan, 1989).

\section{Habitat}

Littoral and sublittoral, usually associated with rock or rock-sand habitats; to $25 \mathrm{~m}$.

\section{Distribution}

New South Wales, Victoria, and southern Western Australia.

\section{Variation}

McLaughlin (2004b) found a tendency for the ratio of ocular peduncle length to shield length to increase with increased animal size in $P$. puniceus, and the same appears to be true for $P$. jalur, but not for $P$. frontalis, the two species for which size ranges could provide information. In $P$. sulcatus, although the ocular peduncles appeared slenderer in larger specimens, the actual ratio of peduncular 
length to shield length remained between 0.5 and 0.6 . However, as in most other species, corneal diameter decreased with increased peduncular length.

Minor variations in the armament of the mesial margins of the dactyls of the chelipeds have been reported for several of the Australian species reviewed. In $P$. sulcatus, although the basic pattern of spination on the chelipeds remained relatively constant, some increase in tubercle size was noted that appeared to be a function of animal size, as was the increase in numbers of corneous spinules on the mesial faces of the dactyls of the ambulatory legs. Additionally, the corneous caps on tuberculate spines on the mesial faces of the dactyls of the chelipeds frequently became more acute, particularly distally in larger specimens.

\section{Affinities}

Morgan and Forest (1991b) discussed the morphological similarities of $P$. sulcatus and $P$. tomentosus (H. Milne Edwards, 1848), a species thought to belong to the fauna of the western coast of South America (e.g., Kinahan, 1857; Rathbun, 1911; Porter, 1935). The characters by which Morgan and Forest (1991b) differentiated $P$. sulcatus and $P$. tomentosus were shown by McLaughlin (2004b), for the most part, to be quite variable. As noted by Morgan and Forest (1991b), H. Milne Edwards' (1848) description of $P$. tomentosus was very brief and could have applied to either species. Porter's (1935) report of $P$. tomentosus gave only collection data. While Rathbun (1911: pl. 50, fig. 1) provided a photograph of the species she identified as $P$. tomentosus, it was insufficient in diagnostic detail to be of any aid in distinguishing between the two taxa. In contrast, Kinanan (1857), in his description of the species he identified as Clibanarius tomentosus (?), presented adequate evidence to recognize his taxon, not only as a species of Paguristes, but also as a species distinct from $P$. sulcatus. In addition to the specimen's colour that was said to be "reddish, with white blotches and dots scattered over calcareous portion of body, especially inferior portions of legs." (Kinanan, ibid, page 351), he described the propodal rasp of the fourth pereopod as "inferior and narrow", a characterization fitting for most species of Paguristes. However, the propodal rasp of $P$. sulcatus is unlike the majority of taxa of this genus (e.g., figs 5b, 9f, 11g, 18f, 20b; Komai, 2001, figs 3h, 7h, 11h. 19h, 23h, 28h). As noted in the abbreviated description and illustrated (Figure 20c), the rasp is uncharacteristically well developed, consisting of four to eight rows of corneous scales.

In having dense setae on the chelipeds and dorsal and ventral margins of the ambulatory legs, $P$. sulcatus is superficially similar to $P$. geminatus $\mathrm{n}$. sp., $P$. squamosus, $P$. pugil, and $P$. alegrias. The prominent boss on the dorsodistal margin the carpus of each chelipeds immediately distinguishes $P$. pugil from the other taxa. Similarly, the distinctive three rows of arcing corneous scales on the mesial faces of the dactyls of each chelipeds readily identify $P$. geminatus. The 2-4 irregular rows of corneous spinules on the mesial faces of the ambulatory dactyls present on both pereopods 2 and 3 in $P$. sulcatus and on the third in P. alegrias separate these two species from the other trio. The narrow and terminally approximate ocular acicles of $P$. alegrias differentiate this taxon from $P$. sulcatus in which the ocular acicles are typically bior multifid and not distally approximate

This Australian species is also superficially quite similar to three species from the western Atlantic, $P$. tortugae Schmitt, 1933, P. angustitheca McLaughlin and Provenzano, 1974, and $P$. perplexus McLaughlin and Provenzano, 1974. Mclaughlin and Provenzano (1974) did not describe the propodal rasps of their species; nevertheless, there can be little doubt of the distinctiveness of $P$. sulcatus. The pale brown ocular peduncles with white near the corneas that Morgan (1989) described for P. sulcatus is in marked contrast to the distinctly white peduncles circumscribed with one or two, often irregular or interrupted bands of black near the bases of the corneas in $P$. tortugae and $P$. angustitheca and the uniformly reddish-orange peduncles, circumscribed with a narrow white band in $P$. perplexus. Additionally, the ocular peduncles of all three Atlantic species are appreciably shorter and stouter than those of $P$. sulcatus.

\section{Remarks}

The smallest specimen of the type series examined has well developed gonopores, paired first female pleopods and a small brood pouch. The second (middle-sized) specimen has the abdomen broken away (but not totally detached); the paired first pleopods appear to have been damaged, the brood pouch is smaller. The largest specimen has small gonopores, no paired first pleopods and a very small brood pouch. Baker (1905) described the male first and second pleopods as being well developed and the female paired pleopods as being weak in this species. If the specimens herein examined are the only syntypes, there are no obvious males.

Morgan (1989, fig. la) illustrated a well developed male first pleopod and described the female brood pouch as being large, sub-elliptical, and covering the anterior half of the abdomen. However, he also noted that in one large male $(\mathrm{s})=$ $13.1 \mathrm{~mm}$ ) in the collections of the Western Australian Museum, development of the gonopods was poor. The first pair were represented by undifferentiated lobes; the second right was missing 
entirely, and the second left was only a minute lobule. Morgan also remarked on the reduction in the size of the gonopores of this specimen, but observed no female gonopores. None of the male specimens examined during the course of the present study, except the above mentioned syntypes, had any similar abnormalities. The female first pleopods in the ovigerous females examined herein were very well developed.

As previously indicated, Morgan (1989) illustrated the first pleopod of $P$. sulcatus. Although the pleopod was shown in what Morgan referred to as "lateral view", it was actually an internal view. No description accompanied the illustration, thus it was not possible to discern the number of rows of corneous hooks on the distal margin of the inferior lamella. In the specimen illustrated herein, the number of rows was an incomplete and somewhat irregular four. However, given the variable number of rows described by McLaughlin and Provenzano (1974) for $P$. tortugae (1-6), it is probable that this is a variable character in $P$. sulcatus as well.

\section{Paguristes alegrias Morgan, 1987a}

Figure 21

Paguristes alegrias Morgan, 1987a: 168, fig. 1. Morgan, 1990: 20. - Davie, 2002: 54.

\section{Holotype}

Northern Territory. NTM Cr 005156, (male, 7.4 $\mathrm{mm}$ ) Coral Bay, Port Essington, 4-6 m, 11.08.1986 (not seen).

\section{Material examined}

Western Australia. WAM C 25809, (1 male, 6.3 $\mathrm{mm} ; 1$ ovig. female, $4.3 \mathrm{~mm})$, stn DA1/98/27 $\left(20^{\circ} 24.04^{\prime} \mathrm{S}, 116^{\circ} 55.04^{\prime} \mathrm{E}\right), 16 \mathrm{~m}, 26.10 .1998$; WAM C 25690, (1 male, $6.3 \mathrm{~mm})$, stn DA1/98/32 (20²3.52'S, $\left.116^{\circ} 54.11^{\prime} \mathrm{E}\right), 14 \mathrm{~m}, 28.10 .1998$; WAM C 27988, (1 male, $6.2 \mathrm{~mm})$, stn DA3/99/47 (20²8.97' $\mathrm{S}$, $\left.16^{\circ} 32.55^{\prime} \mathrm{E}\right), 4-0 \mathrm{~m}, 30.08 .1999$.

\section{Abbreviated description}

Gills biserial; branchiostegites unarmed, but each with dorsal and anterior marginal row of long, fine setae. Shield (Figure 21a) longer than broad, dorsal surface with numerous tufts of dense setae, particularly laterally. Rostrum exceeding lateral projections and reaching from slightly beyond basal margin to midlength of ocular acicles; terminally acute or subacute. Lateral projections obtusely triangular, unarmed or with tiny terminal spinule. Ocular peduncles $0.6-0.8$ length of shield, moderately slender, dorsal surfaces each with tuft of setae proximally; corneal diameter approximately 0.2 of peduncular length; ocular acicles simple or rarely bifid, terminally approximate or nearly so, separated basally by breadth of rostrum. Antennular peduncles reaching to or nearly to basal corneal margins; basal segment with small lateral spine or spinule. Antennal peduncles $0.6-0.8$ length of ocular peduncles; fourth segment with small dorsodistal spine or spinule; third segment prominently drawn out into acute spine; second segment with dorsolateral distal angle produced, usually terminally bifid, but at least partially concealed by dense setae, dorsomesial distal angle with small spine; antennal acicle reaching to midlength of ultimate peduncular segment, terminating in usually bifid spine, lateral and mesial margins each with 1 or 2 spines entirely concealed by tufts of long setae. Antennal flagella varying from shorter than carapace to overreaching chelipeds and longer than carapace, each article with 2 or 3 very short setae.

Chelipeds subequal to distinctly unequal, right slightly to appreciably larger, similar in armature; dactyls and fixed fingers with slender to moderately broad hiatus proximally. Dorsomesial margins of dactyls each with row of conical or tuberculate spines, dorsal surface with 1 or 2 rows of tubercles or tuberculate spines, not concealed by marginal tufts of long plumose setae; mesial faces (Figure $21 \mathrm{~b}, \mathrm{c})$ each with dorsal row of small to moderately large tubercles or tuberculate, sometimes corneoustipped spines and ventral row of somewhat smaller to larger tuberculate spines; ventral surfaces with row of rather widely-space small tubercles or corneous-tipped spines; cutting edges each with row of calcareous teeth in proximal $0.6-0.7,1$ appreciably larger spine proximally, corneous spines distally, terminating in corneous claw. Palms each with 3 or 4 large spines on dorsomesial margin, dorsal surface with several irregular rows of conical or tuberculate spines, 3 or 4 rows extending to tip of fixed finger and partially concealed by tufts of plumose setae, densest marginally; mesial face with few scattered low, broad tubercles; lateral and ventral surfaces each with irregular rows of smaller but more numerous tubercles and scattered setae. Carpi each with 4-6 large spines on dorsomesial margin, dorsolateral margin with row of smaller spines, dorsal surface with few irregular rows of small tubercles or tuberculate spines, all at least partially concealed by dense tufts of long, plumose setae; mesial and lateral faces with scattered tubercles or tuberculate spines, few larger tuberculate spines on distolateral margin ventrally. Meri each with few small to moderately large spines on distal margin extending laterally and mesially, 1 transverse subdistal row of few spines on dorsal margin and numerous tufts of setae; ventromesial and ventrolateral margins each with row of spines, largest mesially.

Ambulatory legs (Figure 21d) with dactyls as long as or slightly longer than propodi. Dactyls each with dense fringe of long plumose setae dorsally 


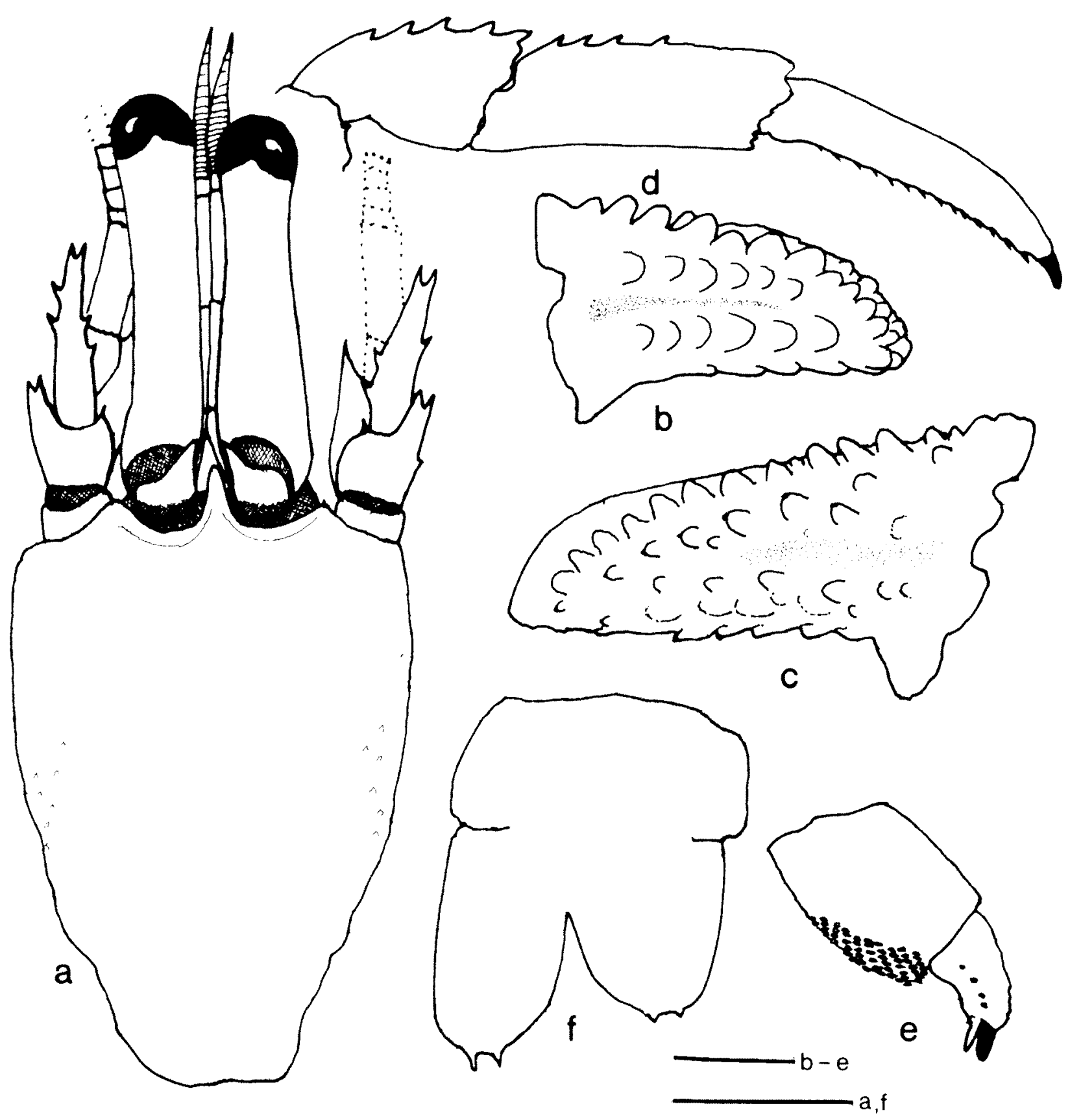

Figure 21 Paguristes alegrias Morgan, 1987a, male $(6.3 \mathrm{~mm})$ (WAM C25809). a, shield and cephalic appendages (aesthetases and setae omitted); b, dactyl of left chela (mesial face, setae omitted); $\mathbf{c}$, dactyl of right chela (mesial face, setae omitted); d, distal three segments of right second pereopod (lateral view, setae omitted); e, dactyl and propodus of right fourth pereopod (lateral view, setae omitted); felson. Scales equal 2 mm (a), $1 \mathrm{~mm}(\mathrm{~b}-\mathrm{f})$.

and ventrally; mesial faces each with 1 or 2 rows of sparse short setae (second pereopods) or 2 to 4 irregular rows of corneous spinules (third pereopods); ventral margins with row of 8-18 corneous spines, at least partially hidden by setae. Propodi each with row of low, sometimes spinulose protuberances or small spines proximally on second pereopods, concealed by tufts of long, plumose setae, only low protuberances and long setae on third; lateral and mesial faces with scattered tufts of setae, ventral margins each with row of tufts of setae. Carpi of second pereopods each with row of spines at least partially concealed by long plumose dorsal setae, third with row of setae and dorsodistal spine; lateral faces each with longitudinal sulcus line with tufts of plumose setae. Meri each with small spine at ventrolateral distal angle; second pereopods each also with ventral row of small spines. Fourth pereopods with moderately well developed propodal rasp (Figure 21e); preungual process approximately as long as claw.

First male pleopods each with single row of very 
small hooked spines on distal margin of inferior lamella; external lobe slightly overreaching inferior lamella; internal lobe short, moderately broad, with long setae marginally and on inner face. Second pleopods each with naked basal segment; distal segment with row of setae on outer margin proximally, endopod with setae on inner margin and terminally; appendix masculina with setae marginally and inner face. Female brood pouch fan-shaped, fully enclosing eggs carried on pleopods $2-4$.

Telson (Figure 21f) with posterior lobes separated by deep median cleft, left larger; terminal margin of left lobe with $1-5$ spines, right with $0-2$ spines.

\section{Colour}

"Shield black with numerous irregularly sized and distributed cream or white spots and patches fusing laterally into irregular bands; bright orange medial stripe extending slightly onto thorax, some orange posterolaterally and on rostral and postorbital margins. Ocular peduncles black with white spots and white band at base of corneas; corneas black. Antennular peduncles black with white spots and patches; antennal peduncles white with irregular black patches and stripes; flagella orange. Dactyls of chelipeds black with white spines and tubercles, white areas fusing to form irregular bands. Propodi similar, sometimes small orange patch proximoventrally. Carpus black and white, orange proximodorsally and proximomesially. Merus black and white, orange patch medially on lateral and mesial surfaces. Ambulatory legs with irregular black and white longitudinal stripes and patches, white predominant on dactyls and propodi, black predominant on carpus and merus. Some orange tinge on propodus, distinct orange patches midlaterally and fainter mesially on carpus and merus. Setae grey, obscuring some coloration on chelipeds" (Morgan, 1987a).

\section{Habitat}

Littoral and shallow subtidal on substrates of sand and coral; $0-6 \mathrm{~m}$.

\section{Distribution}

Port Essington, Northern Territories and Dampier Archipelago, Western Australia.

\section{Variation}

Although Morgan (1987a) described the antennal flagella of $P$. alegrias as being longer than the carapace, in the three Dampier specimens, the flagella that are not broken are consistently longer than the shield, but shorter than the complete carapace. In $P$. jalur, admittedly based on a similarly very limited sample size, length of the antennal flagella appeared to be growth related, as it did in $P$. frontalis; whereas in $P$. palythophilus, variability was noted among several specimens differing little in overall size. In her study of $P$. puniceus, McLaughlin (2004b) indicated that variations in flagellar length might be correlated to sex, i.e., shorter in females than in males; however, the majority of her specimens were female and of smaller sizes than her males.

As indicated in the species description of $P$. algerias, the chelipeds varied from nearly subequal to the right appreciably larger. In their redescription of $P$. jalur, Osawa and Takeda (2004) called attention to the fact that the inequality of the cheliped, specifically the right being larger, was most distinct in the largest specimen they examined, a male. Those authors also noted what they referred to as a "minor discrepancy" between Alcock's (1905) description of subequal chelipeds in P. mundus and his (ibid., pl. 3, fig. 5) illustration in which the right cheliped was distinctly larger than the left. Although the sex of Alcock's specimen(s) was not specified, the illustrated specimen was shown with male unpaired left pleopods 3-5. Similarly, the clearly unequal chelipeds observed in $P$. alegrias were those of the two appreciably larger males. However, it is not possible, with the limited data available, to speculate whether the increase in cheliped inequality is growth or sex related.

Also based on very limited data, the variation in armature of the telson in $P$. alegrias does not appear to be size or sex related. In the smallest Dampier specimen $(4.3 \mathrm{~mm})$, a mature ovigerous female, only a miniscule hint of a spine could be detected on the left posterior telsonal lobe. Of the two males (both $6.3 \mathrm{~mm}$ ) one had one spine on the left lobe and none on the right, whereas the other had two spines on the left lobe and two much smaller spines on the right. Morgan (1987a) did not discuss variation in telsonal armature, but gave the number of spines, presumably of the holotype, a male (7.4 $\mathrm{mm}$ ), as 5 (left) and 2 (right).

\section{Affinities}

Because of its relatively long antennal flagella and ocular peduncles, Morgan (1987a) allied $P$. alegrias to $P$. balanophilus, $P$. mundus, $P$. ciliatus, $P$. seminudus Stimpson, 1858 and $P$. acanthomerus.

For differentiating characters, Morgan (1987a) relied on the interpretations of these taxa given by Alcock (1905) and Miyake (1978). As previously demonstrated, Alcock's (1905) ? P. ciliatus is not Heller's (1862) taxon. Paguristes alcocki, construed by McLaughlin and Rahayu (2005) to be Alcock's (1905) $P$. ciliatus, is very different from $P$. alegrias, although in both taxa the chelipeds are unequal. In $P$. alcocki it is the left that is larger, whereas the right is larger in $P$. alegrias. Paguristes balanophilus and $P$. acanthomerus both have unarmed telsons (cf. 
Morgan and Forest 1991a; Komai 2001; Mclaughlin and Rahayu, 2005); the telson of $P$. alegrias usually has spines on the terminal margins. Paguristes mundus was described by Alcock (1905) as having conspicuous setae only on the dactyls of the ambulatory legs. Additionally, Alcock's (1905, pl. 3, fig. 5) illustration of $P$. mundus shows broad, multifid ocular acicles. The shield, cephalic appendages, chelipeds and ambulatory legs of $P$. alegrias are abundantly setose, whereas the ocular acicles are simple or rarely with one additional spinule. Paguristes alegrias appears most closely allied to $P$. sulcatus, although the development of the propodal rasp of $P$. alegrias is more like that of P. ortmanni Mivake, 1978 than P. sulcatus. Nevertheless, the three taxa are readily distinguishable by, among other characters, the setation of the antennal flagella: each article with 35 short to moderately long setae in $P$. sulcatus; each article with 1 or 2 very short setae in $P$. alegrias; and each article with very long ventral setae in $P$. ortmanni. In life, the three species can be immediately separated by the colour of the ocular peduncles: pale brown with white near corneas in $P$. sulcatus; black with white spots and white band at base of each cornea in $P$. alegrias; and white with three dark chocolate brown stripes in $P$. ortmanni.

\section{Remarks}

Serious doubt of the accuracy of Miyake's (1978) identifications of $P$. seminudus was recently called to the author's attention ( $T$. Komai, personal communication), and a critical comparison of Stimpson's (1858: 247 [85], 1907: 213) descriptions with that of Miyake's (1978: 25) key characters, Miyake and Imafuku's (1980b) fig. 1, and Baba's (1986: 288, fig. 140) diagnosis and photo, clearly support the belief that $P$. seminudus sensu Miyake is a very different taxon from the one described by Stimpson. Although $P$. seminudus sensu Miyake bears no resemblance to $P$. alegrias, the same cannot be said for Stimpson's (1858) P. seminudus. Stimpson's species has never knowingly been collected despite efforts by Dr. T. Komai (personal communication) to locate it in the type locality and vicinity. In a comparison of Stimpson's description of $P$. seminudus with the specimens of $P$. alegrias available, both species have an abundance of long, dense setae on the chelipeds and ambulatory legs that at least partially conceals the spination of these appendages. However, while $P$. alegrias also has dense tufts of setae on the shield, posterior carapace, ocular and antennal peduncles, Stimpson described $P$. seminudus as having the carapace, ocular and antennal peduncles naked. The ocular acicles of the latter species were said to be directed outward, whereas the ocular acicles of $P$. alegrias converge and are nearly approximate distally. Although Morgan (1987a) described the dorsal margins propodi of the second pereopods of $P$. alegrias as being unarmed or at most armed with one or two dorsodistal spines, the Dampier specimens have a row of small spines on the dorsal margin of each second pereopod, albeit somewhat difficult to see unless the setae are cleaned of debris. Perhaps the best differentiating characters of the two species appear to be the chelipeds and telsons. Stimpson (1858) described the chelipeds as being unequal with the left much larger; the dorsal surfaces of the palms were provided with small spines. The telson was said to elongate, with the left lobe most produced. No armature was mentioned, so it might be safe to presume that the terminal margins of $P$. seminudus are unarmed. The chelipeds of $P$. alegrias are similarly unequal, but it is the right that is the larger; the dorsal surfaces of the palms are armed with rounded tubercles. The telson is not appreciably elongated and the left lobe is only slightly larger than the right. The terminal margins each have a very few small spines.

\section{Paguristes miyakei Forest and McLaughlin, 1998} Figure 22

Paguristes setosus, - Miyake, 1978: 27 (in part), fig. 8. Not Paguristes setosus (H. Milne Edwards, 1848).

Paguristes puniceus. - Miyake, 1978: 37 (in part),? not fig. 13.

Paguristes miyakei Forest and McLaughlin, 1998: 191, figs 2, 3. - Forest and McLaughlin, 2000: 78. - Komai, 2001: 424. - McLaughlin, 2004b: 5.

\section{Holotype}

Japan. NSMT CrR 2296, (female, $5.5 \mathrm{~mm}$ ), E of Ohba-dashi (Bank), Sagami Bay, Japan, 180-280 m, 23.01.1965 (not reexamined).

\section{Other material examined}

Japan. CBM-ZC 7982) (2 males, 5.1, $7.6 \mathrm{~mm} ; 4$ females, $4.2-6.3 \mathrm{~mm})$, Sagami Bav $\left(35^{\circ} 08.07^{\prime} \mathrm{N}\right.$, $\left.139^{\circ} 44.88^{\prime} \mathrm{E}\right), 300 \mathrm{~m}, 13.03 .2001$. Western Australia. NTM Cr 6857 (1 male, $6.4 \mathrm{~mm}$ ), Soela stn 01/84/15, Northwest Shelf $\left(1837.4 \mathrm{~S}, 117^{\circ} 02.4 \mathrm{E}\right), 504-508 \mathrm{~m}$, 31.01 .1984

\section{Abbreviated description}

Gills biserial; branchiostegites each with very few tiny spinules on dorsal margin distally and anterior margin dorsally. Shield (Figure 22a) longer than broad; with few spines marginally and/or laterally, and sparse tufts of moderately short setae. Lateral projections broadly triangular, acute, with terminal spine or spinule. Rostrum short, triangular, not reaching level of lateral projections; usually with terminal spinule sometimes partially obscured by moderately long plumose setae. Ocular peduncles 
moderately slender, approximately 0.5 length of shield; longitudinal row of moderately long setae on dorsal surface mesially; corneal diameter approximately 0.2 of peduncular length. Ocular acicles only partially calcified; with simple or weakly bifid terminal spine. Antennular peduncles overreaching distal margins of corneas by 0.4 to nearly entire length of ultimate segment; basal segment with slender spine on dorsolateral margin of statocyst lobe, 1 or 2 spinules on laterodistal margin and spine or spinule on ventromesial distal angle. Antennal peduncles reaching from midlength of corneas to overreaching distal corneal margin by approximately 0.2 length of ultimate segment; fourth segment with small dorsodistal spine; third segment with strong ventrodistal spine; second segment produced distolaterally, terminating in moderate to strong bifid spine, 1-3 small spines on lateral margin, dorsomesial distal angle usually with small spine; first segment unarmed or with small spine at laterodistal margin. Antennal acicle reaching nearly to distal margin of ultimate peduncular segment, with simple or bifid terminal spine; mesial margin with 4-6 small spines, lateral margin with $0-3$ spines. Antennal flagellum (Figure 22b) somewhat longer than carapace; thick; each article with several long randomly-set setae increasing in density distally.

Chelipeds subequal; left (Figure 22c) slightly larger; armature generally similar. Dactyl with row of moderately prominent spines accompanied by tufts of stiff, moderately long setae on dorsomesial margin, dorsal surface with few spines or spinulose tubercles and tufts of stiff setae; mesial face (Figure $22 \mathrm{~d}$ ) with covering with small sometimes corneoustipped spines or spinulose tubercles arranged in longitudinal or oblique rows; cutting edge with row of small calcareous teeth in proximal half, corneous teeth distally; terminating in small corneous claw and slightly overlapped by fixed finger. Palm with 4 or 5 strong spines and tufts of stiff setae on dorsomesial margin, dorsolateral margin not delimited; convex dorsolateral face and dorsal surface with 4-6 rows of somewhat smaller spines, each usually accompanied by tuft of stiff setae, 2 or 3 rows extending nearly entire length of fixed finger; mesial surface unarmed or with 2 or 3 transverse rows of low tubercles and tufts of setae; cutting edge of fixed finger with row of small calcareous teeth in proximal $0.7-0.8$, corneous teeth distally; terminating in moderately small corneous claw. Carpus with 4 or 5 large spines on dorsomesial margin, dorsal surface with 2 irregular rows of adjacent smaller spines separated by unarmed longitudinal area from dorsolateral row of acute or tuberculate spines; lateral face with row of small spines or tubercles and tufts of setae dorsally, laterodistal margin often minutely tuberculate; mesial face with row of spines or tubercles adjacent of dorsal margin. Merus with usually 1-3 spines at dorsodistal margin; dorsal margin with row of spines decreasing in size proximally and accompanied by tufts of moderately long setae; ventromesial and ventrolateral margins each with row of spines and long setae.

Second (Figure 22e) and third pereopods with dactyls $1.2-2.0$ as long as propodi; dorsal margins each with short proximal row of small corneoustipped spines or simple protuberances, accompanied by numerous long bristle-like setae extending to claw (second), or only with bristle-like setae (third); lateral faces each with longitudinal row of sparse tufts of short setae dorsally and ventrally; mesial faces each with longitudinal row of tufts of stiff setae in dorsal half, row of longer and more dense stiff setae adjacent to ventral margin; ventral margins each with row of 20-28 small corneous spines. Propodi each with row of prominent spines and second row of smaller spines or spinules on dorsal margins, accompanied by tufts of long stiff setae (second), or only tufts of stiff setae sometimes arising from low, spinulose protuberances (third); ventral margins each with irregular row of small spines or spinulose protuberances, strongest on second; mesial faces each with single or irregular double row of small spines or spinulose tubercles accompanied by tufts of setae ventrally, and row of setae dorsally; lateral surfaces each with longitudinal row of setae. Carpi each with irregular double row of spines on dorsal margins (second) or dorsodistal spine and sometimes 1 or 2 proximal spinules (third); lateral faces each with 1-3 longitudinal rows of sparse tufts of setae. Meri each with dorsal row of low spinulose protuberances or small spines (second) or low protuberances or few spinules (third); ventral margins each with double row of spines (second) or unarmed (third) and with tufts of moderately long setae. Fourth pereopods each with well developed preungual process at base of claw (Figure 22f).

Male first pleopods (Figure $22 \mathrm{~g}$ ) with tuft of setae basally on basal lobe; inferior lamella with row of setae on lateral margin, distal margin with row of curved spines extending considerable distance along inner margin; internal lobe moderately small, with row of long setae on mesial margin; external lobe extending well beyond distal margin of inferior lamella. Second pleopods (Figure 22h) with basal segment naked; distal segment with row of sparse setae on inner margin; endopod with terminal tuft of setae; appendix masculina with setae marginally and on inner face. Female brood pouch elongate moderately to quite slender.

Telson (Figure 22i) with asymmetrical posterior lobes separated by moderately broad median cleft; left lobe usually appreciably elongate, subtriangular with rounded apex, terminal margin with row of small spines, not concealed by accompanying long 


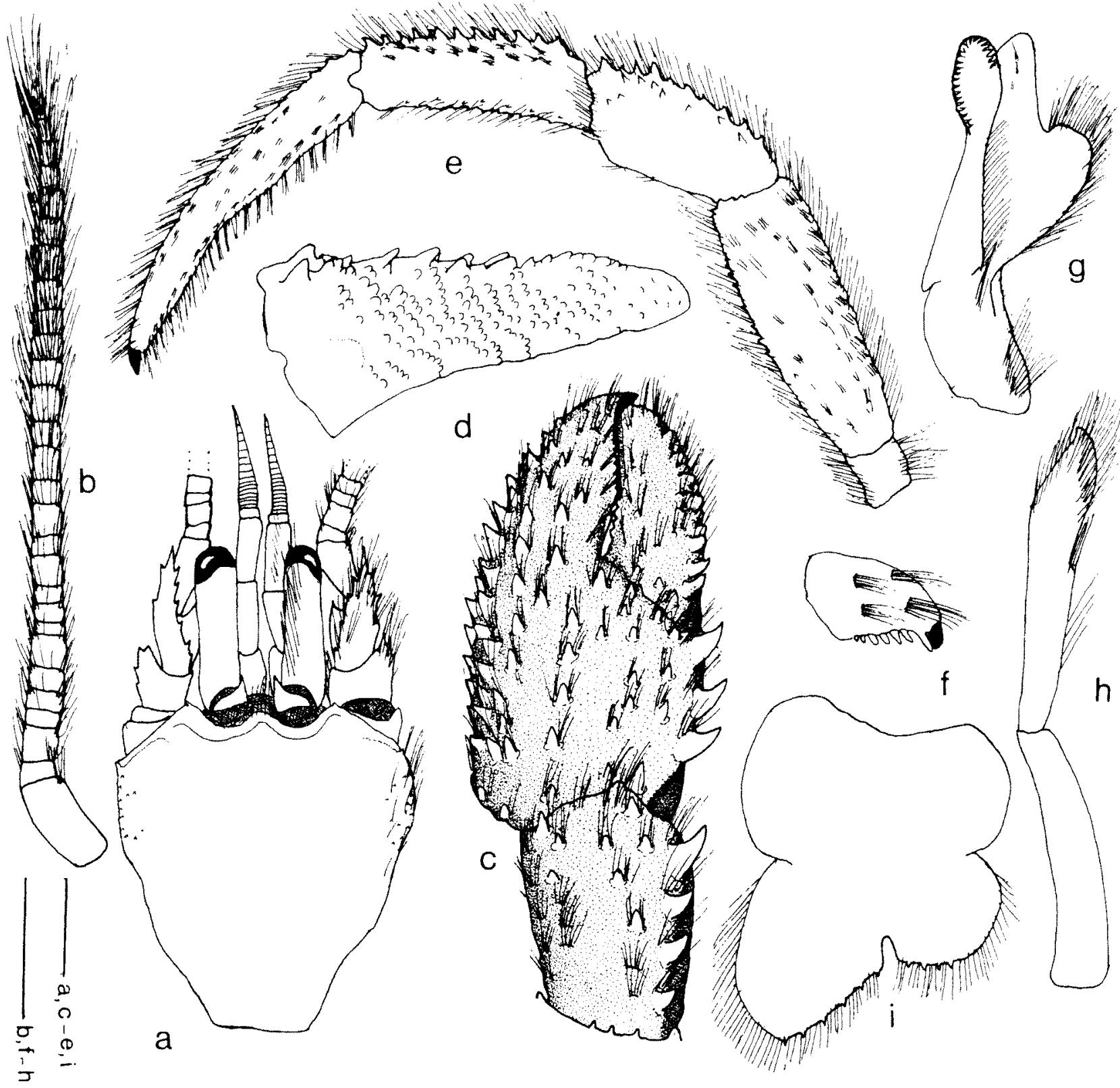

Figure 22 Paguristes miyakei Forest and McLaughlin, 1998, male (6.4 mm) (NTM Cr 6857). a, shield and cephalic appendages (aesthetascs omitted, setae shown on right side only); $\boldsymbol{b}$, antennal flagellum; $\boldsymbol{c}$, chela and carpus of left cheliped (dorsal view); d, dactyl of left chela (mesial view, setae omitted); e, right second pereopod (mesial view); $\mathbf{f}$, dactyl of right fourth pereopod (lateral view); $g$, male right first pleopod; $h$, male right second pleopod; $i$, telson. Scales equal $2 \mathrm{~mm}(\mathrm{a}-\mathrm{c}, \mathrm{e})$ and $1 \mathrm{~mm}(\mathrm{~d}, \mathrm{f}-\mathrm{i})$.

setae; right lobe with terminal margin rounded or slightly oblique, with row of small spines accompanied by long setae.

\section{Colour (in life)}

"Anterior half of carapace and basal segments of chelipeds and walking legs reddish brown; distal two segments of chelipeds and walking legs light reddish brown. Antennules and antennae light reddish brown, dorsal face of eyestalk light reddish brown; ventral face reddish brown" (Miyake 1978: 28).

\section{Habitat}

Sandy mud substrates.

\section{Distribution}

Sagami Bay, Japan; northern Western Australia; $150-508 \mathrm{~m}$.

\section{Affinities}

Paguristes miyakei is most closely allied to $P$. puniceus and differentiation between the two may be difficult. The extent of morphological variability documented for latter species (McLaughlin, 2004b) is 
not known for $P$. miyakei. Until it is, the best characters for identification appear to be the thickness and setation of the antennal flagella and the setation and armature of the pereopodal dactyls. In P. miyakei, the flagella are short and stouter than seen in most species of Paguristes; each flagellar article is ornamented with several moderate to long setae (Figure 22b). Although setation of the flagella of $P$. puniceus varies from very sparse to moderately abundant distally, the density is not known to approach that seen in $P$. miyakei over the entire length of the flagella, or is the flagellum as stout. The mesial faces of the pereopodal dactyls of $P$. miyakei are each provided with a row of evenly-spaced tufts of long, stiff setae ventrally and a less uniform row dorsally; there is no armature other than occasional minute bristle-like spinules ventrally on the third pereopods. In contrast, the mesial faces of these dactyls in $P$. puniceus, although provided with dorsal and ventral rows of setae, the ventral row is not as consistently prominent, and most commonly is accompanied by a row of small to well-developed corneous spinules, at least on the third pereopods. Additionally, but more probably subject to greater variability, in $P$. miyakei the ocular peduncles are shorter and somewhat stouter, antennular peduncles are generally longer, usually overreaching the distal margins of the corneas by nearly the full length of the ultimate peduncular segment; the antennal acicles are basally noticeably broader and the mesial margins armed with more spines.

\section{Paguristes aciculus Grant, 1905}

Figure 23

Paguristes aciculus Grant, 1905: 319, pl. 11, fig. 3, 3a. - McCulloch, 1913: 345. - Gordan, 1956: 321 (literature). - Davie, 2002: 54. - Rahayu, 2006: 365 , figs $10-12$.

\section{Material examined}

\section{Holotype}

New South Wales. AM G 5428, (male, $5.8 \mathrm{~mm}$ ), $45 \mathrm{~km}$ E of Port Jackson (33 $\left.50^{\prime} \mathrm{S}, 151^{\circ} 50^{\prime} \mathrm{E}\right), 550 \mathrm{~m}$, 03.1905 .

\section{Paratype}

AM G 5428 (female, $4.6 \mathrm{~mm}$ ), $45 \mathrm{~km} \mathrm{E}$ of Port Jackson $\left(33^{\circ} 50^{\prime} \mathrm{S}, 151^{\circ} 50^{\prime} \mathrm{E}\right), 550 \mathrm{~m}, 03.905$.

\section{Other material examined}

New South Wales. NMV J 52810, (1 male, 7.0 $\mathrm{mm})$, ENE of Sugerloaf Point, S01/82 stn 67 (32'23'S, 152 $59^{\prime} \mathrm{E}$ ), $278 \mathrm{~m}, 30.01 .1982$; NMV J 52815, (1 male, $6.9 \mathrm{~mm}), 52 \mathrm{~km}$ ENE of Nowra $\left(34^{\circ} 43.33^{\prime} \mathrm{S}\right.$, $\left.151^{\circ} 13.10^{\prime} \mathrm{E}\right)$; NMV J 16069, (2 ovig. females, 5.0, 5.3 $\mathrm{mm})$, off Eden $\left(37^{\circ} 00.6^{\prime} \mathrm{S}, 150^{\circ} 20^{\prime} \mathrm{E}\right)$. Western Australia. NMV J 52811, (1 female, 5.7 mm; 1 ovig. female, $5.1 \mathrm{~mm})$, Western Great Australian Bight (33⒉' S, $127^{\circ} 29.42^{\prime} \mathrm{E}$ ), $300-320 \mathrm{~m}, 27.02 .1976$.

\section{Abbreviated redescription}

Gills biserial. Shield (Figure 23a) longer than broad; dorsal surface with scattered small spines marginally and/or laterally, and few tufts of moderately short setae. Lateral projections triangular, subacute or rounded, with or without terminal spinule. Rostrum triangular, reaching approximately to level of lateral projections in holotype, but more narrowly triangular and longer in allotype; with terminal spinule. Branchiostegites with dorsal surfaces unarmed or with 1 or 2 spines anteriorly, sparsely setose; anterior margins sometimes with 1-4 spines and moderately long setae. Ocular peduncles $0.6-0.8$ length of shield; dorsal surface with sparse setae; corneal diameter $0.2-0.3$ of peduncular length. Ocular acicles acutely triangular, moderately slender, with small terminal spine. Antennular peduncles overreaching distal margins of corneas by $0.2-0.5$ length of ultimate segment; ultimate and penultimate segments with few moderately short setae; basal segment with spine on dorsolateral margin of statocyst lobe. Antennal peduncles usually reaching to basal margins of corneas; fourth segment with very small dorsodistal spine; third segment very prominently drawn out to elongate, acute projection reaching beyond proximal 0.3 of ventral margin of fifth segment, usually with terminal spine; second segment with dorsolateral distal angle produced, terminating in simple or bifid spine, usually 1-3 spines on lateral margin; dorsomesial distal angle with prominent spine and occasionally small spine on dorsomesial face; first segment with unarmed laterodistal margin, ventrolateral margin prominently produced and with terminal spine. Antennal acicle reaching beyond midlength of ultimate peduncular segment but not reaching to distal margin, with prominent bifid terminal spine; mesial margin with 4-6 spines, lateral margin with 2 or 3 spines. Antennal flagellum approximately as long as carapace; each article with 2 to several moderately long and often 1 or 2 shorter, randomlyset setae.

Chelipeds (Figure 23b) subequal; right slightly larger; armature generally similar, all segments with abundance of long setae, not obscuring armature; dactyl and fixed finger with or without moderate hiatus. Dactyl with almost double row of tuberculate spines, frequently corneous-tipped, on dorsomesial margin, dorsal surface with adjacent row of more widely-spaced, tuberculate spines, not extending to tip, and few additional tuberculate spines in proximal half; mesial face (Figure 23c) with covering of moderately closely-spaced, very small tubercles and irregular, longitudinal row of short, stout, often corneous-tipped spines dorsally; 


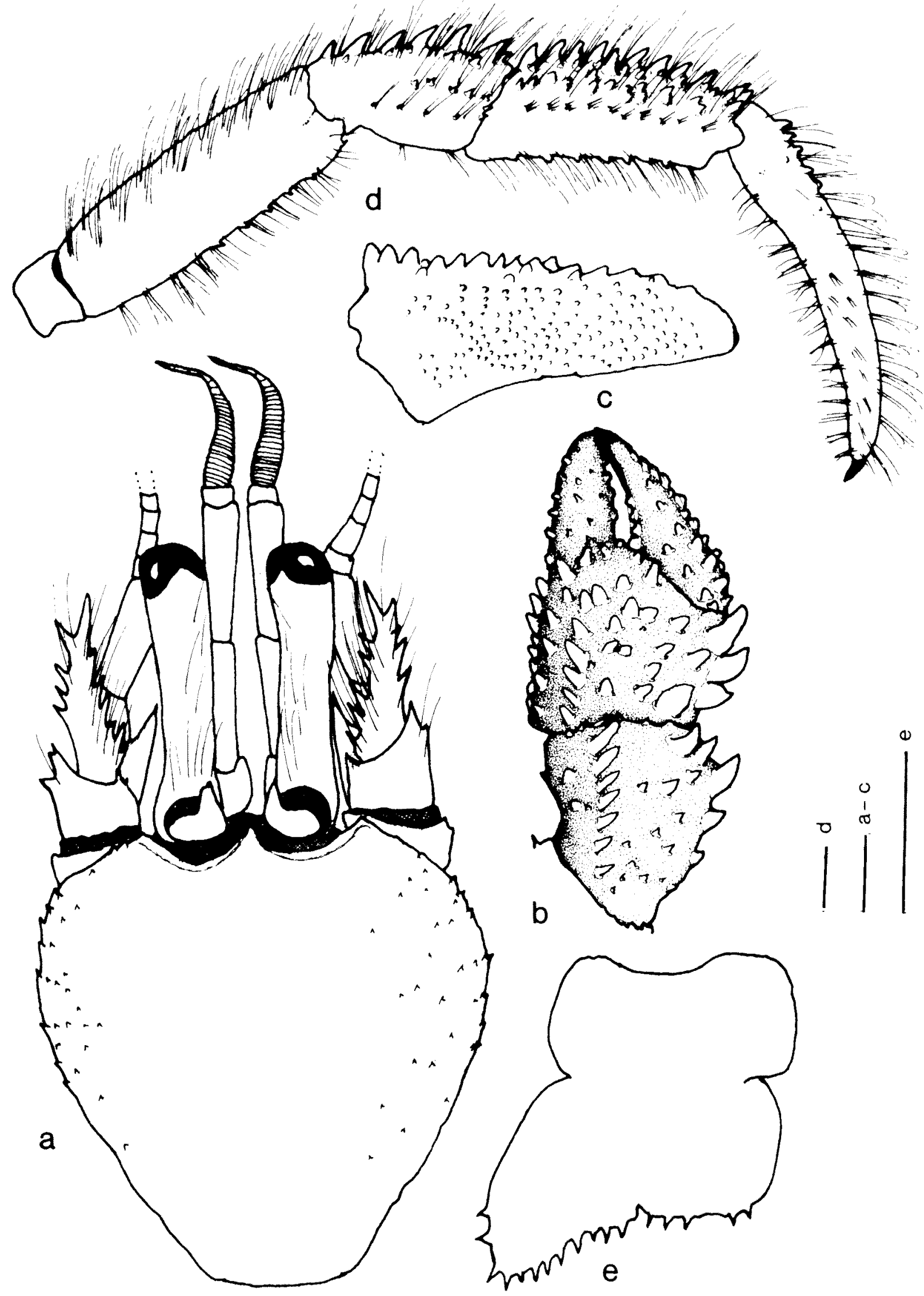

Figure 23 Paguristes aciculus Grant, 1905, a, b, d, e, holotype male (5.8 mm) (AM G 5428); c, male (6.9 mm) (NMV 152815). $\mathbf{a}$, shield and cephalic appendages (aesthetascs omitted); $\mathbf{b}$, chela and carpus of left cheliped (dorsolateral view, setae omitted); $c$, dactyl of left cheliped (mesial view, setae omitted); dright second pereopod (lateral view); e, telson (setae omitted). Scales equal $1 \mathrm{~mm}$. 
ventral surface with few low protuberances; cutting edge with small calcareous teeth in proximal half, corneous teeth distally. Palm with row of 3 prominent, usually corneous-tipped spines on dorsomesial margin and usually 1 additional adjacent prominent spine near proximal margin; convex dorsal surface with several irregular rows of somewhat smaller tuberculate, often corneoustipped spines; fixed finger with marginal row of small spines and few small spines on dorsal surface; mesial and ventral surfaces with few low tubercles or protuberances. Carpus with row of 4 small to large, usually corneous-tipped spines on dorsomesial margin, dorsal surface with irregular row of spines in or slightly mesiad of midline, 2 near dorsomesial distal margin largest, dorsolateral margin with row of prominent spines; mesial and lateral faces with few protuberances; 1 or 2 spines ventrolaterally. Merus with corneous-tipped small spines on dorsodistal margin extending mesially and laterally, and similar subdistal, corneous-tipped spines, remainder of dorsal margin with row of spinulose protuberances; mesial face unarmed, lateral face minutely spinulose, ventromesial and ventrolateral margins each with row of corneoustipped spines. Ischium with row of corneous-tipped spines on ventromesial margin, ventrolateral distal angle usually with 1 or 2 spines.

Second (Figure 23d) and third pereopods with dactyls longer than propodi (both left pereopods missing in allotype); left second slightly to appreciably broader than right second or third pereopods; dorsal margins of dactyls of second pereopods each with short row of spines usually only proximally, third lacking spines, both with row of tufts of long, moderately stiff setae; lateral faces all with scattered tufts of sparse setae; mesial faces each with dorsal and ventral row of tufts of long setae and row of tiny corneous spinules ventrally; ventral surfaces each with row of tufts of long setae and row of 17-29 small corneous spines. Propodi each with row of usually corneous-tipped spines on broad dorsal surface, accompanied by irregular transverse rows of small spines or spinulose protuberances and long setae; mesial faces of second pereopods each with 2 or 3 irregular rows of low protuberances and tufts of setae, most prominent on left; third pereopods with similar, but much weaker protuberances; ventral margins each with row of small spines (second) or low protuberances (third) and tufts of setae. Carpi each with row of prominent, often corneous-tipped spines and adjacent more irregular row of much smaller spines and tufts of long setae on dorsal surface (second pereopods) or irregular single or double row of small spines or spinules and tufts of long setae (third pereopods); lateral faces each with 2 short longitudinal rows of small spines or spinules; mesial faces each with few spinules on or near distal margin in dorsal half. Meri each with low, sometimes spinulose protuberances and tufts of long setae on dorsal margin; ventral margins of second pereopods each with row of spines and tufts of long setae, third with low, sometimes spinulose protuberances and tufts of long setae. Ischia of second pereopods each with 2 small spines on ventromesial margin, third unarmed; all with few tufts of long setae. Fourth pereopods each with long, slender preungual process at base of claw.

Male first pleopods each with tuft of setae on outer margin of basal lobe; inferior lamella with row of setae on outer margin, distal margin with 1 row of spines; internal lobe moderately small, with row of long setae on inner margin; external lobe extending beyond distal margin of inferior lamella. Female brood pouch generally subquadrate, with long marginal setae.

Telson (Figure 23e) with deep lateral incisions separating anterior and posterior lobes; very asymmetrical posterior lobes separated by shallow, slit-like median cleft; left lobe subtriangular with rounded apex, terminal margin with row of moderately large spines, continued onto lateral margin, and not concealed by accompanying long setae; right lobe roundly subquadrate, terminal margin with few slightly smaller spines, not continued onto lateral margin.

\section{Colour}

"Chelipeds, anterior part of carapace, and ambulatory legs salmon-pink shading into cream" (Grant, 1905).

\section{Habitat}

Deep water, $360-550 \mathrm{~m}$.

\section{Distribution}

New South Wales, Australia; Indonesia.

\section{Affinities}

In having the mesial faces of the dactyls of the chelipeds provided with a covering of small spines, and lacking dense setation on the ambulatory legs obscuring the armature, $P$. aciculus appears most closely allied with P. puniceus. McLaughlin (2004b) provided an in depth evaluation of intraspecific variability in the latter species that is not available for $P$. aciculus. The two species share many characters in common, and it is possible that when intraspecific variation can be assessed, Grant's (1905) species will proved to be conspecific with $P$. puniceus. However, until such data are available, $P$. aciculus is being retained as a valid taxon. Based on the data available for Grant's (1905) species, it would appear that the row of stout spines on each mesial face of the dactyls of the chelipeds, the 
prominent row of spines delimiting the dorsolateral margin of the carpus of the left cheliped, and the two or three rows of protuberances on the mesial faces of the propodi of the second and third pereopods would differentiate $P$. aciculus from $P$. puniceus. Additionally, the mesial faces of the ambulatory dactyls each has a ventral row of corneous spinules in $P$. aciculus, but a row of spinules is typical only on the third pereopods of $P$. puniceus.

\section{Remarks}

Three specimens are listed by the Australian Museum as syntypes, one male and one female (wet) and one male (dry), although Davie (2002) listed only two syntypes. However, Grant (1905) indicated that 12 males and one female were collected. He specifically stated that the description was based on the largest male, and provided dimensions for it as "(type)". According to Article 73.1 .1 of the International Code of Zoological Nomenclature (1999) the specified male is the holotype by original designation. The male preserved in alcohol is presumed to be the holotype as its morphology agrees well with the stylized illustration provided by Grant. Additionally, the lengths of the ocular peduncles of this specimen $(4.8 \mathrm{~mm})$ approximate the $5 \mathrm{~mm}$ length given by Grant (1905) for his largest specimen. All of Grant's measurements are to the nearest $0.5 \mathrm{~mm}$, thus it is probable that the measurement of the ocular peduncle was rounded off. The dry specimen is very fragile ( $P$. Berents, personal communication) and no information is available on its size relative to the preserved specimen.

McCulloch (1913), after examining "the type", corrected several errors in Grant's (1905) original description. However, McCulloch (1913) failed to mention that the ultimate segment of the antennal peduncle is unarmed, rather than being sharply pointed and bearing six spinules on the inner margin and three on the outer margin distally. The described spination correctly is attributed to the antennal acicle.

\section{Paguristes puniceus Henderson, 1896 Figure 24}

Paguristes puniceus Henderson 1896: 527. - Alcock and Anderson, 1897: pl. 32, fig. 1. - Alcock 1905: 38, pl. 3, fig. 6. - Kemp and Sewell, 1912: 25. Balss, 1924: 768. - Gordan, 1956: 323 (literature). - Komai, 2001: 423. - McLaughlin, 2004b: 15, figs 1, 2. - Rahayu, 2006: 365 .

Paguristes puniceus var. unispinosa Balss, 1912: 92.

Not Paguristes puniceus. - Miyake, 1978: 38, fig. 13 (see Remarks).

\section{Material examined}

Syntypes of Paguristes puniceus

India. NHM 96.9.8.22, 1903.4.5.193-202, 207, 208, (6 males, $7.4-10.1 ; 4$ females, $6.8-8.0$; 35 ovig. females, 6.1-8.9; 1 juvenile, $2.7 \mathrm{~mm}$ ), Investigator station 162, off Madras (13 51.2' N, 80 28.2' E), $265-$ 457 m, 30.01.894; NHM 1903.4.5.201-202 (1 male, $7.7 \mathrm{~mm} ; 1$ ovig. female, $7.0 \mathrm{~mm}$ ), Investigator station $166\left(13^{\circ} 34.9^{\prime} \mathrm{N}, 80^{\circ} 32.2^{\prime} \mathrm{E}\right), 243 \mathrm{~m}, 08.02 .1894$.

\section{Syntypes of Paguristes puniceus var. unispina}

Indonesia. ZMB 16478 (2 females, 3.7, $5.7 \mathrm{~mm}$ ), Valdivia station 194, Sumatra $\left(0^{\circ} 15^{\prime} \mathrm{N}, 98^{\circ} 08^{\prime} \mathrm{E}\right), 594$ m, 01.02.1899.

\section{Other material examined}

Andaman Sea. NHM 1903.4.5.207-208 (2 males, $9.5,9.9 \mathrm{~mm})$, Investigator station $235\left(14^{\circ} 13^{\prime} \mathrm{N}\right.$, $\left.93^{\circ} 40^{\prime} \mathrm{E}\right), 677-766 \mathrm{~m}, 08.04 .1898$. Queensland. WAM C 20231 (1 male, $8.0 \mathrm{~mm}$ ), Nimbus Ck, stn 13, coll. A.J. Bruce, 01.1968.

\section{Abbreviated description}

Gills biserial. Shield (Figure 24a) slightly longer than broad; dorsal surface sometimes with few spines or spinules marginally and/or laterally, and often with tufts of moderately long setae, particularly laterally. Rostrum narrowly to broadly triangular, rarely broadly rounded and nearly obsolete; not reaching or slightly overreaching level of lateral projections, rarely reaching midlength of ocular acicles, unarmed or with terminal spine or spinule. Lateral projections obtusely triangular to subquadrate, sometimes simply broadly rounded, with or without terminal spine or spinule. Branchiostegites often with few widely-spaced spinules or small spines on dorsal margins distally or lateral surfaces dorsally, sometimes with 1 or 2 irregular rows of very small spines; usually with 1 3 small spines to tiny spinules on anterior margins. Posterior carapace with posterior median plate extremely narrow to moderately broad. Ocular peduncles $0.3-0.7$ length of shield; dorsal surfaces each sometimes with row of long setae; corneal diameter 0.1-0.3 of peduncular length. Ocular acicles triangular to subovate, frequently only distal halves calcified; each terminating acutely, subacutely or bluntly, often with terminal spine. Antennular peduncles overreaching distal margins of corneas by 0.1 length of ultimate segment to 0.2 length of penultimate segment. Antennal peduncles usually varying from reaching from bases of corneas to distal corneal margins, occasionally slightly shorter to slightly longer; fourth segment usually with small dorsodistal spine; third segment with ventrodistal margin produced; second segment with dorsolateral distal angle produced, usually terminating in bifid spine, occasionally 1 or 


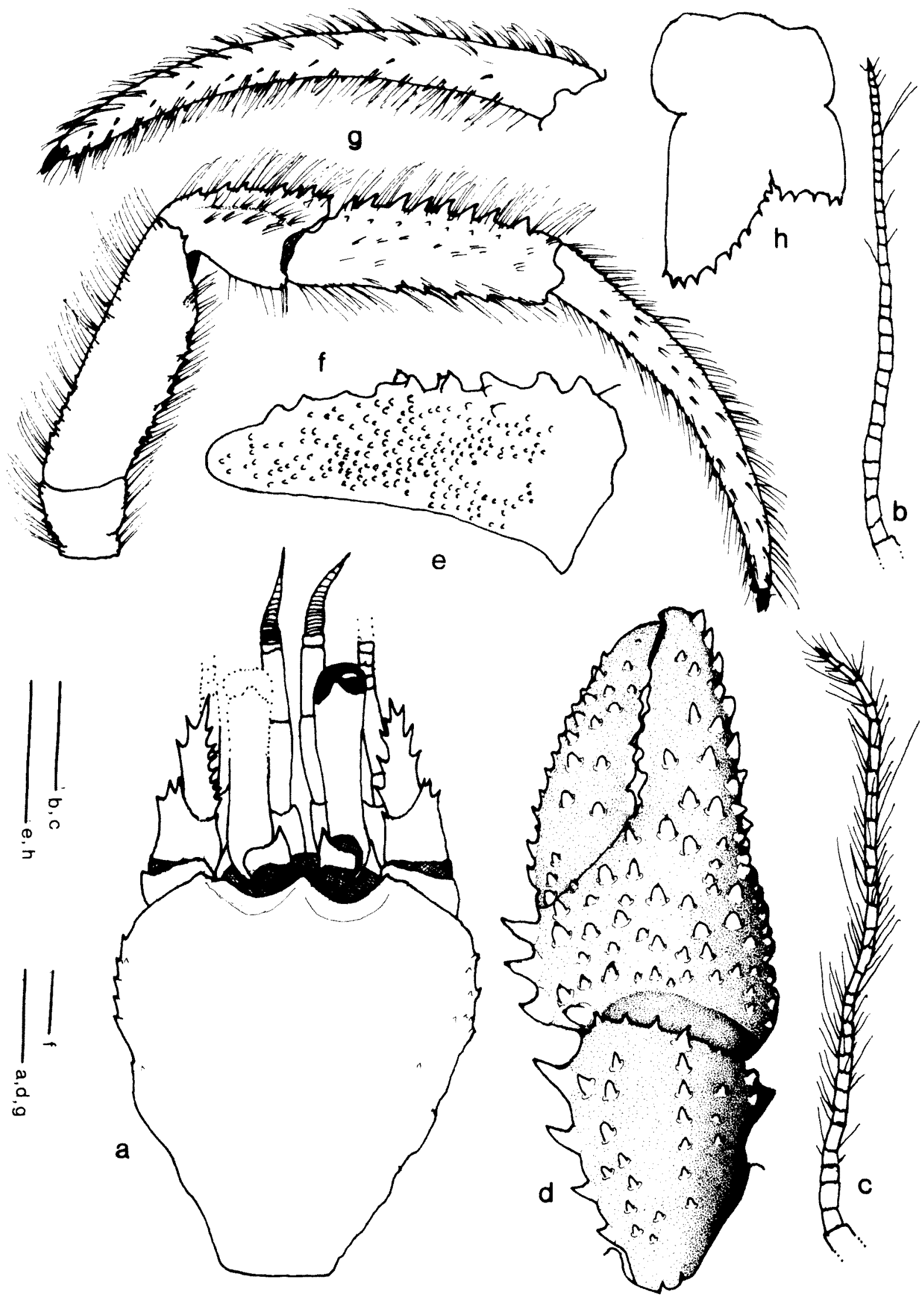

Figure 24 Paguristes puniceus Henderson, 1896, male $(8.0 \mathrm{~mm})$ (WAM C 20231). a, shield and cephalic appendages (aesthetascs and setae omitted); b, c, antennal flagellum (redrawn from McLaughlin, 2004b); d, chela and carpus of right cheliped (dorsal view, setae omitted); e, dactyl of right cheliped (mesial view, setae omitted); $\mathbf{f}$, right second pereopod (lateral view); $\mathbf{g}$, dactyl of right third pereopod (mesial view) $\mathbf{h}$, telson (setae omitted). Scales equal $2 \mathrm{~mm}$. 
2 smaller spines on lateral margin distally and tufts of long setae, dorsomesial distal angle unarmed or with 1 spine. Antennal acicle reaching from 0.2 of fifth peduncular segment to slightly overreaching distal segmental margin, with prominent terminal, most frequently bifid, spine; mesial margin with 06 spines, lateral margin with $0-3$ spines, sometimes partially obscured by long setae. Antennal flagellum varying from only as long as shield to slightly longer than entire carapace; each article usually naked or with only 1 or 2 long setae, less frequently with more numerous, longer setae distally (Figure 24b, c).

Chelipeds approximately equal or occasionally subequal, left or right (Figure 24d) slightly larger; armature generally similar; dactyl and fixed finger usually with slender, sometimes moderately broad, hiatus proximally. Dactyl (left partially regenerated in Australian specimen) with row of spines or spinulose tubercles on dorsomesial margin, often accompanied by tufts of moderately long setae; dorsal surface unarmed or with few tubercles, spines or spinules and tufts of setae; mesial face (Figure 24e) with irregular rows of very small, often corneous-tipped spinules or spines, frequently accompanied by short stiff setae; cutting edge with row of small calcareous teeth in proximal $0.4-0.5$, corneous teeth distally; terminating in small corneous claw and frequently slightly overlapped by fixed finger. Palm with row of 3 or 4 moderate to prominent spines and tufts of setae on dorsomesial margin, dorsolateral margin not delimited; weakly convex dorsal surface with 4-6 irregular rows of somewhat smaller spines, each accompanied by tuft of setae, 3 or 4 rows extending nearly entire length of fixed finger; cutting edge of fixed finger with row of small calcareous teeth; terminating in large corneous claw. Carpus with row of 4-6 prominent spines on dorsomesial margin, irregular row, often double distally, of smaller tuberculate spines usually mesiad of midline and moderate to smaller row on weakly delimited dorsolateral margin, accompanied by tuft of setae. Merus with 1-3 spines and moderately long setae on dorsodistal margin; dorsal margin with subdistal, transverse row of spines and setae, remaining dorsal margin with row of short spinulose ridges or spinulose protuberances accompanied by tufts of long setae; mesial and lateral faces weakly spinulose, ventromesial and ventrolateral margins each with row of small spines or spinules and long setae.

Second (Figure 24f) and third pereopods with dactyls 1.4-2.4 length of propodi; dorsal margins each with row of tufts of moderately long setae, few individual to short row of small to moderate, often corneous-tipped, spines proximally, always on second pereopods, sometimes also on third; lateral faces each with 2 or 3 longitudinal rows of sparse tufts of short setae; mesial faces each with 2 or 3 rows of tufts of setae and commonly ventral row of very small corneous spines, at least on third pereopods (Figure $24 \mathrm{~g}$ ); row of $14-34$ small to tiny corneous spines on each ventral margin often partially concealed by long, stiff setae. Broad dorsal surfaces of propodi of second pereopods each with row of spines and most frequently additional row of smaller spines, spinules, tubercles or protuberances accompanied by tufts of long setae; dorsal surfaces of third with low protuberances and tufts of long setae, and not infrequently also row of smaller spines or spinules; ventral margins each with row of spinulose protuberances or tuberculate spines, often corneous-tipped, and tufts of setae, spines better developed on second pereopods. Carpi each with tufts of long setae and 2 irregular rows of moderately small to moderately large spines on dorsal margins (second) or small dorsodistal spine and frequently 1 or 2 to row of smaller additional spines (third); lateral faces each with weak longitudinal sulcus, frequently with 1 to several small spines distally, and occasionally median row of spinules. Meri each with dorsal row of low protuberances and tufts of long setae; ventral margins each with row of small spines and tufts of moderately long setae (second) or only low protuberances and long setae (third); ventrolateral distal angle with 0-3 spinules (second), or 1 small spine (third) and with tufts of moderately long setae. Fourth pereopods each with long, slender preungual process at base of claw; carpi each with or without small dorsodistal spine.

Male first pleopod with tuft of setae on outer margin of basal lobe; inferior lamella with row of setae on outer margin, distal margin with 1 row of curved spines extending considerable distance along outer margin; internal lobe moderately small, with row of long setae on inner margin; external lobe often extending slightly beyond distal margin of inferior lamella, occasionally shorter. Second pleopod with elongate basal segment, naked or with few setae; endopod with few fine setae on inner margin and tuft of longer setae terminally; appendix masculina with long setae marginally and on inner face. Female brood pouch varying from subtriangular to subquadrate, sometimes almost fan-shaped, margins usually weakly scalloped, with or without marginal long setae. Tergal thickenings above acetabula of pleopods 2-4 sometimes with fringe of long dense setae, setation sometimes restricted to tergal thickening above fourth pleopod, occasionally entirely absent.

Telson (Figure 24h) with moderately deep lateral incisions separating anterior and posterior portions; asymmetrical posterior lobes separated by $\mathrm{U}$ shaped median cleft; left lobe usually appreciably elongate, subtriangular with rounded apex, terminal margin with row of small to moderately small spines, usually not continued onto lateral 
margin, and sometimes partially concealed by accompanying long setae; right lobe with terminal margin rounded, with row of small spines, accompanied by long setae, not extending onto lateral margin.

\section{Colour (in life)}

"Legs and anterior part of carapace light pink. Eye-stalks rather darker pink." (Henderson, 1896).

\section{Habitat}

Reported from substrates of mud and sandy mud inhabiting gastropod shells, frequently with attached unidentified Epizoanthus. The shell of the Australian specimen was entirely covered by an unidentified anemone.

\section{Distribution}

Bay of Bengal and Travancore coast, India; Andaman Sea; Indonesia; northeastern Australia; 150-766 m.

\begin{abstract}
Affinities
Among Australian species, Paguristes puniceus is morphologically most similar to $P$. miyakei, $P$. aciculus and $P$. longisetosus. Not only do all four species share the similar telsonal armature, the chelipeds of each is armed with prominent spines and long setae that do not conceal the surface integument. However, the ocular acicles of $P$. miyakei, $P$. puniceus and $P$. aciculus are triangular and each is usually armed with a simple terminal spine; very rarely is a tiny accessory spinule present. In contrast, the ocular acicles of $P$. longisetosus are subquadrate, rarely bifid, and most commonly are provided with $3-5$ prominent spines. The spines on the mesial faces of the dactyls of the chelipeds of the former three species also are smaller and more numerous than seen in $P$. longisetosus.
\end{abstract}

\section{Remarks}

Miyake (1978) reported $P$. puniceus from Sagami Bay; however, after reexamining 11 of Miyake's specimens, Komai (2001) concluded that although three species had been confounded under the name $P$. puniceus, none actually represented Henderson's (1896) taxon. One specimen Komai (2001) assigned to $P$. miyakei, five specimens were transferred to his newly established $P$. doederleini Komai, 2001, and five were thought to represent an as yet undescribed species.

The Australian specimen differs from the syntypes of $P$. puniceus particularly in the shape of the posterior median plate of the carapace. As described by Henderson (1896) the median plate was extremely narrow. McLaughlin (2004b) referred to the configuration as "funnel-shaped", but noted that the narrowness of the elongated portion of the "funnel" was less pronounced in the specimens from a second station in the Bay of Bengal, from the Andaman Sea, and from Indonesia. The Australian specimen, a male from Nimbus Creek, is somewhat larger, and shows some tendency toward narrowing of the posterior portion of the plate. That the transformation of the posterior median plate from moderately broad to funnel-shaped as a function of animal size cannot be verified on the basis of the available material. However, as indicated previously, a similar transition seems, at least in part, to be correlated with animal size in $P$. frontalis.

The occurrence of $P$. puniceus is another example of unanticipated range extensions into Australian waters. In its symbiotic association with one or more species of Epizoanthus, $P$. puniceus is allied to another heretofore "alien" species, $P$. palythophilus. These two species, while sharing numerous morphological characters, are immediately separated by the armatures of the telsons. The posterior lobes of the telson of $P$. palythophilus have unarmed margins, whereas those of $P$. puniceus are armed with small spines.

\section{Stratiotes Thomson, 1899}

Stratiotes Thomson, 1899: 185. - Rahayu, 2005: 4.

Paguristes. - Alcock, 1905: 30 (in part). - Forest, 1954: 170 (in part). - Forest and de Saint Laurent, 1968: 67 (in part). - Forest and McLaughlin, 2000: 58 (in part).

\section{Type species}

Stratiotes setosus Thomson, 1899, junior subjective synonym of Paguristes setosus (H. Milne Edwards, 1848).

\section{Diagnosis}

Twelve pairs of bi- or quadriserial gills [no pleurobranch on fifth or eighth thoracic somites]. Shield with rostrum well developed or reduced. Ocular acicles simple, bi- or multidenticulate. Antennal peduncle with supernumerary segmentation. Maxillule with external lobe of endopod well developed, distinctly recurved. Third maxilliped with coxal segments approximate or somewhat separated; crista dentata usually well developed, no accessory tooth; merus usually with 1 or more spines; carpus, propodus and dactyl usually unarmed.

Chelipeds equal, subequal or unequal, often with left considerably larger, similar or dissimilar in armament; claws corneous, fingers opening in horizontal or oblique plane. Fourth pereopods subchelate or weakly semichelate, with or without preungual process developed at base of claw.

Males with paired gonopores; first and second 
pleomeres each with pair of pleopods modified as gonopods; unpaired, unequally biramous left pleopods on pleomeres $3-4$, pleopod 5 with external ramus well developed, internal ramus rudimentary. Females usually with paired gonopores; first pleomere with pair of modified pleopods; following 3 pleomeres with unequally biramous left pleopods, pleopod 5 as in male; brood pouch usually well developed, occasionally entirely absent.

Uropods asymmetrical. Telson with lateral incisions; posterior portion divided by median cleft into 2 subequal to markedly unequal lobes.

\section{Stratiotes tuberculatus (Whitelegge, 1900)}

Figure 25

Clibanarius sp. - Whitelegge, 1889: 232; McCulloch, 1913: 344

Paguristes tuberculatus Whitelegge, 1900: 169, fig. 1, 1A. - McCulloch, 1913: 343, fig. 51. - Hale, 1927a: 90. - Griffin, 1967: 306. - Morgan, 1989: 395, fig. 1b. - Davie, 2002: 56.

Paguristes sp. - Haig and Ball, 1988: 173

Stratiotes tuberculatus. - Rahayu, 2005: 6, figs 1-3.

\section{Material examined}

\section{Syntypes}

New South Wales. AM G 2221 (54 syntypes, most not removed from shells; 10 measured: $1.5-2.1 \mathrm{~mm}$ ), from $3.0-5.5 \mathrm{~km}$ off $\mathrm{N}$ end of Newcastle Bight (32 $\left.50^{\prime} \mathrm{S}, 152^{\circ} 03.5^{\prime} \mathrm{E}\right), 49 \mathrm{~m}, 07.03 .1898$.

\section{Other material examined}

Queensland. AM P 37790 (1 female, $1.8 \mathrm{~mm}$ ), Masthead I., $31 \mathrm{~m}$, coll. F.E. Grant. New South Wales. AM P 20690, (1 male, $2.1 \mathrm{~mm}$; 9 ovig. females, 2.4-2.7 mm), Australian Museum Benthic Shelf Survey, stn 26, off Malabar, Sydney, $66 \mathrm{~m}$, 26.01.1973; AM P 20688 (7 males, 1.9-2.5 mm; 2 females, $2.5,2.7 \mathrm{~mm}$; 10 ovig. females, $1.9-2.6 \mathrm{~mm}$ ), off Malabar, Sydney, 1972-1973. Victoria. NMV J 20514 and NMV J 52820, (1 female, $1.4 \mathrm{~m}$; 1 female, $2.2 \mathrm{~mm}$ ), Bass Strait off Lakes Entrance (3805's, 148 08.30'E); NMV J 52816 (1 ovig. female, $1.9 \mathrm{~mm}$ ), south of Waratah Bay (38 59.54'S, 14600.42 ' ); 36$38 \mathrm{~m}, 15.06 .1989$.

\section{Abbreviated description}

Biserial gills. Shield (Figure 25a) longer than broad. Rostrum broadly triangular, not overreaching level of lateral projections. Lateral projections triangular, with marginal or submarginal small spine. Branchiostegites each with row of very small spines on dorsal margin in distal half. Ocular peduncles slender to moderately stout,
$0.6-0.7$ length of shield, usually slightly swollen basally; comeal diameter $0.2-0.3$ of peduncular length; ocular acicles elongate, very slender, terminating acutely, occasionally with moderately long, plumose seta between. Antennular peduncles overreaching distal margins of comeas by 0.2-0.5 length of ultimate segment; basal segment with acute spine dorsolaterally.

Antennal peduncles reaching nearly to or slightly overreaching distal margins of corneas; second segment with dorsolateral distal angle produced, terminating usually in prominent bifid spine, subdistal spine frequently present on lateral margin, dorsomesial distal angle with small to moderately large spine; acicle reaching to or slightly beyond proximal margin of ultimate peduncular segment, terminating in prominent bifid spine, mesial margin with 2-5 spines, lateral margin with 1 or 2 small spines. Antennal flagellum varying from appreciably shorter to longer than carapace, each article with long, paired setae ventrally.

Chelipeds unequal and dissimilar, left cheliped much larger; carpus and chela of both chelipeds articulating obliquely, putting dorsal surfaces in lateral positions relative to body axis. Left cheliped (Figure 25b) with dactyl equal to or distinctly longer than palm; upper surface with irregular single to double row of conical or tuberculate spines and tufts of moderately long, plumose setae; outer surface with prominent longitudinal sulcus, occasionally flanked dorsally and/or ventrally with few small tubercles; inner surface unarmed or with row of small, conical spines and tufts of plumose setae dorsally; with or without hiatus between dactyl and fixed finger. Palm with single to double row of conical or tuberculate spines on upper margin and often additional, at least partial adjacent row on outer surface, frequently with few individual, conical or tuberculate spines proximally and 2 or 3 longitudinal rows of clusters of 1 to several conical or elongate, blunt or spiniform tubercles, lower median row extending onto fixed finger on weakly elevated broad ridge; lower margin with 1-3 irregular rows of tubercles and tufts of moderately long, plumose setae. Carpus with row of conical, sometimes corneous-tipped spines on upper margin; outer surface with numerous, but not closely-packed, smaller spines, often forming irregular longitudinal rows, distal margin unarmed or with row of small spines or spinules, 1 spinule to prominent spine at lower distal angle; inner surface with scattered low tubercles, lower distal margin with few plumose setae. Merus with 1 spine at dorsodistal margin, dorsal margin with row of smaller spines or sometimes only spinulose protuberances and tutts of plumose setae; lateral face with scattered small spinules, at least in distal half, and tufts of plumose setae in dorsal half, distal margin with row of small 
spines in dorsal half, ventrolateral margin with row of small, often corneous-tipped spines; ventromesial margin also with row of often more prominent, corneous-tipped spines, mesial face glabrous or with scattered tiny spinules; ventral surface with moderately long plumose setae. Ischium unarmed or with row of minute to small spinules or granules on ventromesial margin.

Right cheliped (Figure 25c) with row of small spines on upper margin of dactyl, at least partially obscured by long plumose setae; outer surface with irregular row of spinules accompanied by plumose setae; inner surface with faint longitudinal sulcus at least proximally, and sometimes few tiny spinules and short setae. Palm with row of 3-5 moderately small spines on upper margin; outer surface convex, 3-5 irregular longitudinal rows of quite small spines, at least partially obscured by long plumose setae, lower 2 spine rows extending nearly to tip of fixed finger. Carpus with row of spines on upper margin, increasing in size distally and partially obscured by long plumose setae; outer face with row of small spines in upper half and 1 to several spinules or very small spines in lower half. Merus with 1 prominent spine on dorsodistal margin and slightly smaller subdistal spine, both partially obscured by long, plumose setae, remainder of dorsal margin with row of tiny spinules or spinulose protuberances concealed by long, plumose setae; ventromesial margin with long, plumose setae not obscuring row of small spines; lateral face with few scattered spinules, ventrolateral margin with few long, plumose setae and row of very small spines or spinules.

Ambulatory legs with left third (Figure 25d) markedly dissimilar. Dactyls of second and right third pereopods 1.2-1.4 longer than propodi; dorsal surfaces of second pereopods each with row of small, corneous-tipped spines, dorsal surface of third right with even smaller spinules or sometimes only small corneous spinules, all obscured by long plumose setae; ventral margins each with row of small corneous spines, also concealed by tufts of long, plumose setae; mesial and lateral faces of dactyl of second pereopods each with faint to prominent longitudinal sulcus; mesial and lateral faces of right third convex or each with very faint longitudinal sulcus in proximal half. Propodi of second pereopods each with dorsal row off small, often corneous-tipped spines and ventral row of corneous spinules, all obscured by tufts of long plumose setae; propodus of third right with row of much smaller corneous-tipped spines, occasionally only plumose setae dorsally; ventral surfaces all with long plumose setae. Carpi each with dorsal row of spines partially concealed by long, plumose setae; spines of third right smallest. Meri of second pereopods each with dorsal row of spinules and long plumose setae, ventral margins each with row of small spines; merus of third right with spinules or spinulose protuberances and long setae on dorsal margin, ventral margin with long plumose setae and small spine at ventrolateral distal angle. Left third pereopod with dactyl 1.1-1.3 longer than propodus; dorsal surface with 1 or 2 irregular rows of minute spinules and long plumose setae; lateral face with broad longitudinal sulcus, flanked dorsally by 1 or 2 rows of minute spinules and ventrally by row of acute and/or blunt tooth-like spines, ventral surface spinulose, at least proximally, but armature frequently masked by long plumose setae; mesial face with faint longitudinal sulcus. Propodus with minutely spinulose dorsal surface and long plumose setae; lateral face with broad longitudinal sulcus flanked dorsally by row of very small spines and ventrally by row of blunt or subacute tooth-like spines; ventral surface with long plumose setae and row of tiny spinules, at least proximally. Carpus with small spine at dorsodistal margin and row of spinules on dorsal surface; lateral face with faint longitudinal sulcus in dorsal half. Merus with row of very small spines or spinules on dorsal surface concealed by long, plumose setae; ventrolateral distal angle with small spine, ventral margin with long plumose setae.

Male first pleopods (Figure 25e, f) short and moderately stout; distal elements thick. Inferior lamella with outer surface convex, distal and free inner margin short, armed with row of small hooked spines, lateral margin with row of setae; external lobe extending well beyond distal margin of inferior lamella; inner lobe small, rounded, moderately setose. Second pleopods (Figure 25g) elongate; proximal segment with 3 or 4 short setae; endopod with few setae, appendix masculina with marginal and surface setae. Female brood pouch developed only as narrow rectangular lobe, free margin with abundance of long plumose setae.

Telson (Figure 25h) with posterior lobes asymmetrical, right smaller; right terminal margin with few setae and 2 to several spinules, not extending onto lateral margin, left with setae and 6 or more small spines, often extending onto lateral margin.

\section{Colour}

"Antennae and ambulatory legs annulated with narrow reddish bands. Chelas bright red, tips of fingers of larger hand white, body and limbs scantly clothed with brownish hairs" (Whitelegge, 1900).

\section{Habitat}

The Newcastle substrate was reported as sand and pebbles; soft substrates, usually associated with seagrass meadows; subtidal to $50 \mathrm{~m}$ according to Morgan (1989). McCulloch (1913) reported that the shells of this species were almost always 


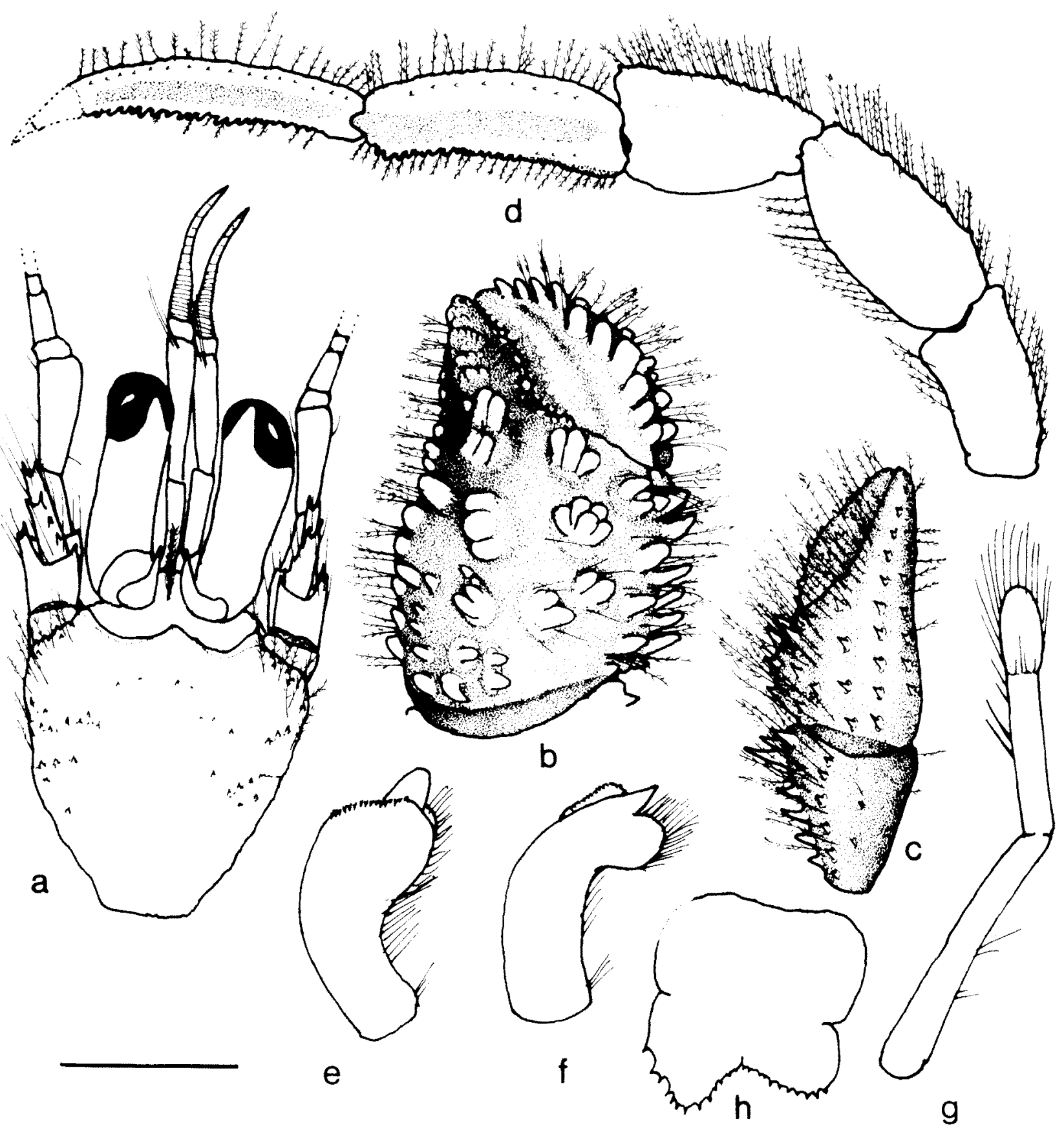

Figure 25 Stratiotes tuberculatus (Whitelegge, 1900), male syntype (1.5 mm) (AM G 2221). a, shield and cephalic appendages (aesthetascs omitted); $\mathbf{b}$, chela of left cheliped (outer face); $\mathbf{c}$, chela and carpus of right cheliped (outer face); d, left third pereopod (lateral view); e, f, male right first pleopod; $g$, male right second pleopod; $h$, telson (setae omitted). Scale equals $1 \mathrm{~mm}$ (a-d) and $0.5 \mathrm{~mm}(\mathrm{e}-\mathrm{h})$.

accompanied by polyzoan colonies; however, Morgan (1989) did not find such an association in specimens collected in Western Australia. Some of the shells from Sydney similarly carried polvzoan colonies.

\section{Distribution}

Queensland, New South Wales, Victoria and Western Australia, Australia; Indonesia; subtidal to $90 \mathrm{~m}$.

\section{Affinities}

Stratiotes tuberculatus is very distinctive and not easily confused with any other species currently assigned to the genus.

\section{Remarks}

Haig and Ball (1988: 173) reported on the reexamination by Haig of three specimens in the collections of the Australian Museum (AM G 5732) that had been attributed to Pseudopaguristes hians 
(Henderson, 1888) (as Paguristes) by Grant and McCulloch (1906). Haig correctly determined that none of the specimens represented Henderson's (1888) taxon, but that two were identifiable as Pseudopaguristes monoporus (as Paguristes). The third specimen, a female $(\mathrm{sl}=1.8 \mathrm{~mm})$, Haig said could not be identified and probably belonged to an undescribed species. That specimen has now been reexamined and identified as Stratiotes tuberculatus. All of the specimen's appendages are disarticulated and the left cheliped is missing. The vial contains two right second pereopods belonging to two different species, one left second and a pair of third pereopods. Although four of the five agree reasonably well with the second and third pereopods of $S$. tuberculatus, the ambulatory legs have not been considered in making the species determination because of the uncertainty of "ownership." Four primary characters support the accuracy of the identification: 1) the pleurobranch is missing from the thoracic wall above the second pereopod, but arthrobranchs are present on the cheliped and third maxilliped, providing a gill count of 12 pairs; 2) the antennal flagellum is provided with a series of paired long setae; 3 ) the right cheliped agrees well with small specimens of Whitelegge's (1900) species; and 4) the armament of the telson also corresponds to that species. Additionally, the brood pouch, reported absent by Haig and Ball (1988), is represented in this specimen by a tuft of setae, a condition not uncommon in small specimens where brood pouch development is reduced as it is in $S$. tuberculatus.

The illustrations presented here are of a quite small male, and the ocular peduncles are short and moderately stout, as are the peduncles of the two small males reported by Rahayu (2005: fig. 1) from Indonesia. Two rather diagrammatic illustrations accompanied Whitelegge's (1900: fig. 11, 11A) original description and the ocular peduncles in figure 11 are similarly moderately short, but more slender. McCulloch's (1913: fig. 51) illustration of a much larger individual shows considerably longer ocular peduncles, which confirms the observations of the present study, that peduncular length is a function of animal size. Similarly, armament of the left chela is size related in $S$. tuberculatus. In small individuals (e.g., $1.2 \mathrm{~mm}$ ), spination of the outer surface consists of single conical spines. With increasing size, these often become double and eventually form clusters of compound spines or tubercles.

\section{Pseudopaguristes McLaughlin, 2002a}

Paguristes. - Forest and de Saint Laurent, 1968: 67 (in part).

Pseudopaguristes McLaughlin, 2002a: 186. - Asakura and Kosuge, 2004: 57. - Rahayu, 2005: 25.

\section{Type species}

Pseudopaguristes janetkae McLaughlin, 2002a, by original designation.

\section{Diagnosis}

Eight pairs of functional phyllobranchiate gills (no pleurobranchs on fifth and eighth thoracic somites); arthrobranchs of third maxillipeds and chelipeds markedly reduced or absent; remaining gills bi- or quadriserial. Rostrum usually well developed. Ocular acicles well developed, widely separated. Antennal peduncles with supernumerary segmentation; antennal acicles moderately long, spinose; antennal flagella of short to medium length, slightly shorter to slightly longer than carapace.

Mandible with smooth mesial margin; palp 3segmented. Endopod of maxillule with well developed, recurved external lobe. First maxilliped with setose epipod. Third maxilliped with crista dentata consisting of row of quite small teeth, no accessory tooth.

Chelipeds subequal or unequal, sometimes dimorphic, dissimilar or similar; claws corneous, fingers opening in horizontal or oblique plane. Fourth pereopods with or without preungual process at base of dactylar claw. Fifth pereopods chelate.

Males with single or paired gonopores; unpaired or paired pleopods modified as gonopods on first and second pleomeres; unpaired, unequally biramous left pleopods on pleomeres 3 and 4, fifth uniramous. Females with paired gonopores or single gonopore on coxa of left third pereopod; paired, modified, uniramous pleopods, on first pleomere; following 3 pleomeres with unpaired, unequally biramous left pleopods; fifth with exopod well developed, endopod rudimentary; brood pouch absent or present, sometimes represented only by row of setae.

Uropods markedly asymmetrical. Telson with lateral indentations; posterior lobes slightly to markedly asymmetrical.

\section{Remarks}

Pseudopaguristes, clearly is very closely allied to Paguristes and Stratiotes, sharing many morphological attributes and exhibiting the same types of morphological plasticity that are seen in the latter genera. Shared characters include, but are not limited to, the recurved external lobe of the maxillulary endopod that is very similar to those described for species of Paguristes s.s. and Stratiotes (e.g., Forest, 1954; McLaughlin and Provenzano, 1974, 1975; Forest and McLaughlin, 2000; Rahayu, 2005, 2006). An epipod on the first maxilliped, comparable to that seen in Paguristes and Stratiotes (cf. Boas 1880; McLaughlin and 
Provenzano 1974, 1975, Rahayu, 2005, 2006), is also present in Pseudopaguristes. Reduction in the number of functional gills is the principal character setting the three genera apart. Gill loss is considered indicative of evolutionary advance (cf. de Saint Laurent-Dechance, 1966; Rahavu, 2005). Species of Stratiotes exhibit loss of the pleurobranch on the fifth thoracic somite thus indicating that evolutionary processes are ongoing within the genus. These processes have progressed still farther in Pseudopaguristes, with additional gill loss, gonopod and gonopore loss, and in some species, a shift from left to right handed asymmetry, although the latter can be seen in a few species of Paguristes s.s. and Stratiotes as well.

\section{Key to the Australian species of Pseudopaguristes}

1. Epistome beneath interocular lobe produced, usually armed with 1-4 tiny spinules; fourth segment of antennal peduncle with prominent ventrodistal spine; males with paired gonopores; first and second gonopods well developed, paired; females with paired gonopores ................................. P. laurentae

Epistome beneath interocular lobe not produced nor armed; fourth segment of antennal peduncle without prominent ventrodistal spine; males with single gonopore on right fifth coxa, males first gonopods with left reduced, second with left absent; females with single gonopore

P. monoporus

\section{Pseudopaguristes laurentae (Morgan and Forest, 1991a)}

Figure 26

Paguristes laurentae Morgan and Forest, 1991a: 678, figs 12, 13. - Davie, 2002: 55. - Komai, 1999: 11.

Paguristes brachytes Komai, 1999: 3, figs 1-4.

Paguristes incomitatus, - Miyake, 1978: 41 (in part). - not Paguristes incomitatus Alcock, 1905.

Pseudopaguristes laurentae. - Rahayu, 2005: 25.

Pseudopaguristes gracilis Rahayu, 2005: 28, figs 10, 11.

\section{Holotype}

Western Australia. WAM C 20052 (male, 4.6 $\mathrm{mm}$ ), $W$ of $W$ end of Rottnest $1 ., 146 \mathrm{~m}$ (not seen)

\section{Paratypes of Paguristes laurentae}

Western Australia. WAM C 20053 (2 ovig. females, $1.6,2.1 \mathrm{~mm}$ ), SW of Pt Cloats, CSIRO stn $187\left(2329^{\prime} \mathrm{S}, 113^{\circ} 11^{\mathrm{E}} \mathrm{E}\right), 137 \mathrm{~m}, 07.10 .1963$.

\section{Paratypes of Pseudopaguristes brachytes}

Japan. CBM ZC 4835 (1 male, $3.1 \mathrm{~mm}$ ), Okinoyama Bank, Sagami-nade $\left(35^{\circ} 00.1\right.$ 'N, 139 40.3'E), 98-100 m, 23.10.1996; CBM ZC 4837 (1 male, $2.8 \mathrm{~mm}$; female, $1.9 \mathrm{~mm}$; 1 ovig. female, 3.0 $\mathrm{mm}),\left(3458.5 \mathrm{~N}, 1399^{\circ} 34.1 \mathrm{E}\right), 121-129 \mathrm{~m}, 23.10 .1996$.

\section{Other material examined}

Japan. CBM ZC 6825 (3 males, $1.8-3.0 \mathrm{~mm}$ ), off Shionomisaki, Kii Pen. (33 26.7' N, 13539.2'E), 180 $\mathrm{m}, 16.04 .1997$; CBM ZC (1 male, $2.8 \mathrm{~mm}$ ), (3458.5' N, 139 34.1'E), 121-129 m, 23.10.1996. New South Wales. AM P 60300 (1 male, $2.8 \mathrm{~mm}$ ) and AM P 60299 (1 temale, $1.7 \mathrm{~mm}$ ), NE of Coffs Harbor (30 14.84'S, $153^{\circ} 27.55^{\prime} \mathrm{E}$ ), $200 \mathrm{~m}$, coll. I.K. Lowry and K. Dempsey, 09.10.1994; NMV J 17426 (1 male, 3.3 $\mathrm{mm})$, stn slope 21 (36 57.4'S, 150'18.8' E), $220 \mathrm{~m}$, 20.07.1986; NMV J 17425 (1 ovig. female, $3.7 \mathrm{~mm}$ ), (37 00.4'S, $\left.150^{\circ} 18.8^{\prime} \mathrm{E}\right)$; NMV J 16069 (1 male, 3.2 $\mathrm{mm})$, off Eden $\left(37^{\circ} 00.6^{\prime} \mathrm{S}, 150^{\circ} 20^{\prime} \mathrm{E}\right)$. Victoria. NMV J 52245 (1 female, $1.8 \mathrm{~mm}$ ), stn $\$ S 01 / 00198$ $\left(38^{\circ} 09.9^{\prime} \mathrm{S}, 149^{\circ} 38.7\right)$; NMV J 52244 (2 males, $2.7,4.5$ $\mathrm{mm}$; 2 females, $2.7,3.3 \mathrm{~mm}$; ovig. female, $3.0 \mathrm{~mm}$ ), stn SS01/00 184 (38 12.57'S, 149 37.33'E), $382 \mathrm{~m}$, 21.04.2001. Tasmania. NMV J 52812 (1 male, 3.2 $\mathrm{mm})$, Bass Strait $\left(39^{\circ} 44^{\prime} \mathrm{S}, 148^{\circ} 47.5^{\prime} \mathrm{E}\right), 329 \mathrm{~m}$, 24.11.1973. South Australia. SAMA PC 0169 (1 female, $2.4 \mathrm{~mm} ; 1$ ovig. female, $2.3 \mathrm{~mm}$ ), $\mathrm{R} / \mathrm{V}$ Franklin stn PL 94.37, W of Kangaroo I., 220 m, coll. K. Gowlett-Holmes, 30.06.1994; NMV J 55246 (1 male, $1.8 \mathrm{~mm})$, Great Australian Bight (33 15.9'S, $\left.130^{\circ} 37.8^{\prime} \mathrm{E}\right)$. Western Australia. WAM C 20224 (1 male, $2.0 \mathrm{~mm}$ ), SW of Pt Cloats, CSIRO stn 187 $\left(23^{\circ} 29^{\prime} \mathrm{S}, 113^{\circ} 11^{\prime} \mathrm{E}\right), 134 \mathrm{~m}, 07.10 .1963$.

\section{Amended description}

Shield (Figure 26a) slightly longer than broad; dorsal surface with scattered small spinules and sparse tufts of long plumose setae. Rostrum triangular, usually with tiny apical spinule, not reaching or slightly overreaching level of lateral projections. Lateral projections triangular, each with terminal spine or spinule. Ocular peduncles moderately long and slender, $0.6-0.8$ length of shield; somewhat inflated basally, dorsomesial surfaces each with row of long setae; corneal diameter $0.1-0.2$ peduncular length; ocular acicles each with several long plumose setae and 1-3 terminal spines, terminal spine frequently distinctly larger; epistome visible beneath ocular lobes, somewhat produced anteriorly, and usually armed with $1-4$ small spines. Antennular peduncles, when fully extended, varying from reaching bases of corneas to exceeding distal corneal margins by 0.5 0.8 length of ultimate peduncular segments; penultimate segment unarmed or with small spine on ventral surface at approximately midlength; basal segment with ventrodistal spine. Antennal peduncles reaching from distal 0.3 of ocular 


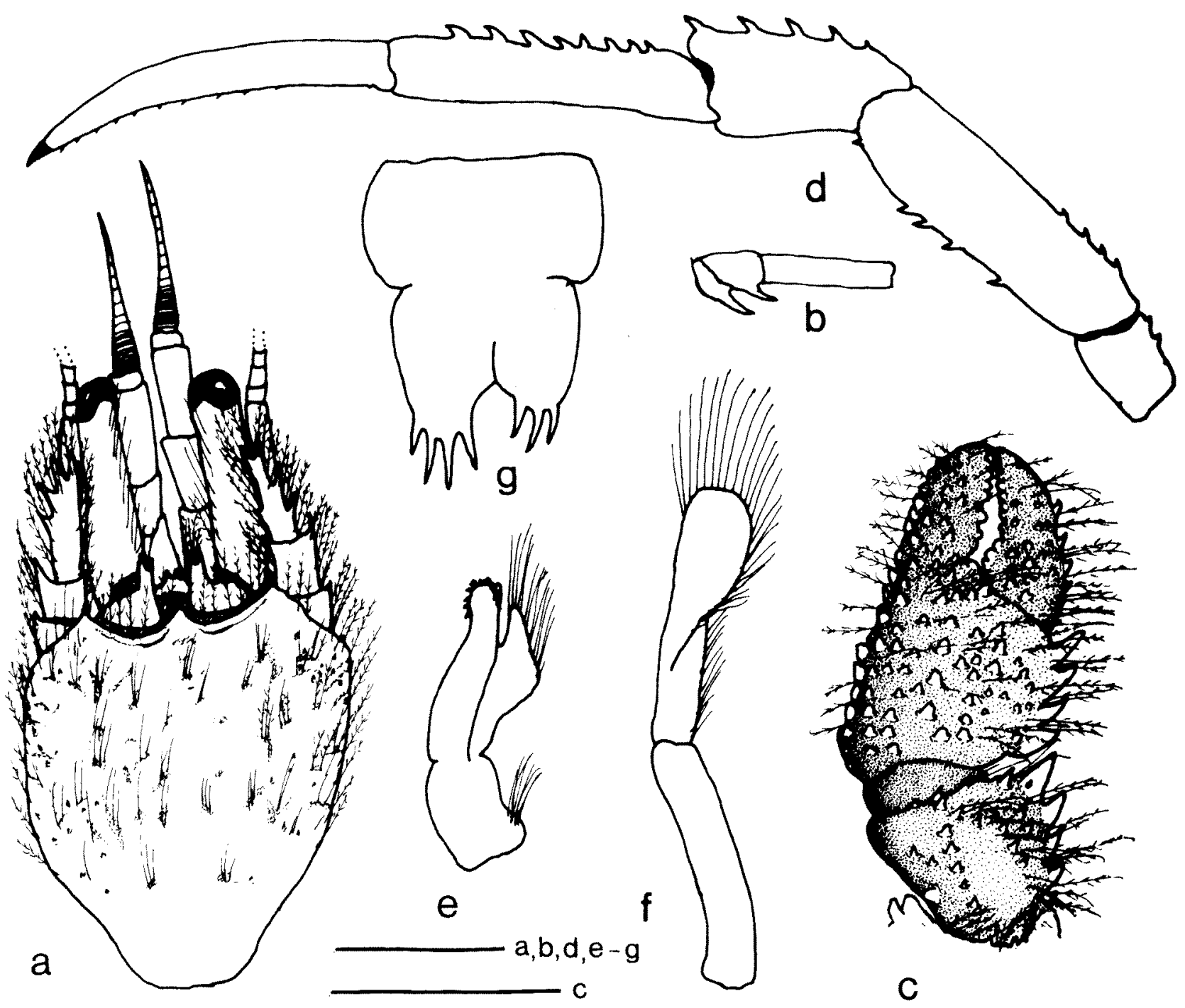

Figure 26 Pseudopaguristes laurentae (Morgan and Forest, 1991a), a-c, f, ovig. female paratype (2.1 mm) (WAM C 20053); d, e, male ( $2.0 \mathrm{~mm}$ ) (WAM C 20224). a, shield and cephalic appendages (aesthetascs omitted); $\mathbf{b}$, distal three segments of right antennal peduncle (lateral view, setae omitted); c, chela and carpus of left cheliped (outer surface); d, left second pereopod (lateral view, setae omitted); $\mathbf{e}$, male right first pleopod; $\mathbf{f}$, male right second pleopod; $\mathrm{g}$, telson (setae omitted). Scales equal $1 \mathrm{~mm}(\mathrm{a}-\mathrm{d})$ and $0.5 \mathrm{~mm}(\mathrm{~d}-\mathrm{f})$.

peduncles to bases of corneas; fifth segment usually with ventrodistal spine or spinule; fourth and third segments (Figure 26b) each with very prominent ventrodistal spine; second segment with numerous long plumose setae, dorsolateral distal angle produced, with terminal spine, ventromesial distal angle with 1 or 2 spines; first segment with small dorsolateral spine and prominent spine at ventrodistal angle. Antennal acicles each reaching to or slightly beyond midlength of fifth peduncular segment, terminating in prominent, simple or broadly bifid spine, lateral margin with 1 or 2 spines, mesial margin with 0-2 spines; all segments with tufts of long, frequently plumose setae. Antennal flagella much shorter to approximately equal to carapace length, articles each with 3-5 long and moderately short setae.
Chelipeds subequal, left (Figure 26c) slightly larger, armature similar. Dactyl slightly longer palm, upper margin with row of small to quite prominent spines, surface with scattered small spines or tubercles and sparse, long plumose setae; mesial face with median row of tubercles or small protrusions each accompanied by tuft of sparse setae, decreasing in prominence with increasing animal size; cutting edge with row of small calcareous teeth and short row of corneous teeth distally. Palm with 4-6 large spines on upper margin, outer face with irregular rows of small to moderately large spines or tubercles, extending onto fixed finger and accompanied by scattered, long plumose setae; cutting edge of fixed finger with row of small calcareous teeth; usually noticeable hiatus between dactyl and fixed finger. Carpus with similar counterclockwise rotation; 
upper margin with 4 or 5 large spines, outer face with smaller spines forming 3 very irregular rows, 1 larger tubercle proximally near lower margin, few small spines on distal margin and scattered long plumose setae. Merus with row of acute spines on dorsal margin; ventromesial and ventrolateral margins each with row of small spines and scattered long setae.

Second (Figure 26d) and third pereopods similar from left to right; dactyls 1.0-1.5 longer than propodi; surfaces all with numerous, randomly set setae; row of small spines on each ventral margin, at least distally, often obscured by surrounding setae. Propodi of second pereopods each with row of slender acute spines accompanied by long but moderately sparse plumose setae on dorsal margin, third unarmed; ventral margins with low, sometimes spinulose protuberances (second) or unarmed (third) and sparse long setae. Carpi each with single or irregular double row of prominent spines on dorsal surface of second pereopods, third each with dorsodistal spine and, occasionally, 1 or 2 additional small spines in proximal half of dorsal surface, both also with sparse long setae. Meri each with small spines or spinules on dorsal margin, at least in proximal half; ventral margins of second pereopods also each with few spines, also with moderately dense, plumose setae dorsally and ventrally.

First male pleopods (Figure 26e) each with row or only tuft of setae mesially on basal lobe; inferior lamella with distal short row of small hooked spines; external lobe slightly overreaching inferior lamellae; internal lobe with marginal row of long setae. Second pleopods (Figure 26f) each with appendix masculina distinctly twisted, with marginal long setae; gonopores paired. Females with paired gonopores and modified first pleopods, brood pouch small and triangular, not covering large eggs.

Sixth pleonal tergite sometimes with 1 or 2 posterolateral spines on one or both sides. Telson (Figure 26g) with anterior lobes each occasionally armed with 1 or 2 small spinules on lateral margin; posterior lobes asymmetrical, left larger; lobes roundly subtriangular to subrectangular, each with spines varying from several moderately small to 2 4 very prominent spines, occasionally simply 3 or 4 long, slender spines.

\section{Colour (in preservative)}

"Shield pale brown, with specks of maroon or orange. Ocular peduncle with characteristic marking of dark orange on pale yellowish brown ground color; on dorsal and mesial surfaces, marking sometimes showing as transverse band at about midlength of peduncle, or interrupted dorsally; on lateral surface, marking extending near corneal base as longitudinal band; on ventral surface proximal 0.6 of peduncle dark reddish brown, distal 0.4 with tinge of orange. Proximal two segments of antennular peduncle orange, distal segment colorless. Antennal peduncle with tinge of orange; flagellum without marking. Cheliped generally pale orange-brown, dorsal margin of merus darker. Ambulatory pereopods generally pale orange-distal parts of propodi and dactyls (except unguis) whitish" (Komai, 1999).

\section{Habitat}

Gastropod shells; collected on substrates of calcareous rocks, dead coral and sponges from depths between 69-350, possibly to $500 \mathrm{~m}$.

\section{Distribution}

Eastern Australia from New South Wales to Victoria, Tasmania, South Australia and Western Australia to the vicinity of Point Cloates; South Sulawesi, Madura Bay and Kai Islands, Indonesia; Sagami-nada, Torishima Island, Kii Peninsula. Japan.

\section{Affinities}

Pseudopaguristes laurentae is a very distinctive species with certain characters unlike other species currently assigned to the genus. Two characters in particular set this species apart from the remainder. These are the spinose margin of the epistome and prominently armed ventrodistal margin of the fourth peduncular segment of the antennal peduncle.

\section{Remarks}

Morgan and Forest (1991a) considered that Pseudopaguristes laurentae (as Paguristes) most closely resembled Paguristes incomitatus Alcock, 1905 and $P$. puniceus; however, these authors were relying of the descriptions provided by Alcock (1905) and Miyake (1978) for their evaluation. Interestingly, Komai (1999) included a specimen identified by Miyake (1978) as $P$. incomitatus in his type series of Pseudopaguristes brachytes (as Paguristes), and Komai (2001) found specimens identified by Miyake (1978) as both Paguristes incomitatus and $P$. puniceus referable to his new species P. doederleini Komai, 2001. Clearly, Miyake's diagnoses of both species were not accurate.

Komai (1999), in his description of P. brachytes, differentiated his Japanese material from Morgan and Forest's (1991a) Australian species by the longer antennular peduncles with an unarmed penultimate segment, bi- or trifid ocular acicles, and unarmed ventral margins of the ambulatory dactyls of the latter species. Each species was based on six specimens, with shield lengths varying from 1.4-4.6 $\mathrm{mm}$ in $P$. laurentae and $1.8-3.9 \mathrm{~mm}$ in $P$. brachvtes. 
Neither Morgan and Forest (1991a) nor Komai (1999) noted the spinose development of the epistome in each species, nor did the authors check the gill number in the species they described. Rahayu (2005) did check the paratype of $P$. laurentae (MNHN Pg 4489) in the collections of the Muséum national d'Histoire naturelle and found only eight pairs present. On the basis of the reduced gill number, Rahayu transferred Paguristes laurentae to Pseudopaguristes. A comparison of paratypic and additional specimens of $P$. brachytes has shown that characters thought by Komai (1999) to distinguish his taxon from $P$. laurentae all fall within the range of variation found in the larger sample size of Morgan and Forest's (1991a) species available in the present study. Rahayu (2005) compared the amended description of $P$. laurentae with her material of $P$. gracilis and concluded that it too was conspecific with the former species (D.L. Rahayu, pers. comm.).

\section{Pseudopaguristes monoporus (Morgan, 1987c)} Figure 27

Paguristes hians. - Grant and McCulloch, 1906: 33. - McCulloch, 1913: 346 (key). Not Paguristes hians Henderson, 1888.

Paguristes monoporus Morgan, 1987c: 379, figs 1-3. - Haig and Ball, 1988: 173. - Morgan, 1990: 23. Jones and Morgan, 1994: 122, 2 unnumbered figs. - Jones and Morgan, 2002, 122, 1 unnumbered fig. - Rahayu and Komai, 2000: 30. - Davie, 2002: 55. - McLaughlin, 2002 b: 391.

Pseudopaguristes monoporus - Rahayu, 2005: 27.

\section{Holotype}

Northern Territory. NTM Cr 004345 (male, 4.1 $\mathrm{mm}), \mathrm{W}$ end, Orontes Reef, Port Essington $\left(11^{\circ} 04^{\prime} \mathrm{S}\right.$, $132^{\circ} 03^{\prime} \mathrm{E}$ ), 11-12 $\mathrm{m}, 10.10 .1986$ (not seen).

\section{Material examined}

Western Australia. WAM C 29562 (1 ovig, female, $2.3 \mathrm{~mm}), \operatorname{stn} \mathrm{DA} 2 / 99 / 57\left(1.9 \mathrm{~km} \mathrm{~N}\right.$ of $20^{\circ} 29.03^{\prime} \mathrm{S}$, $\left.116^{\circ} 30.45^{\prime} \mathrm{E}\right), 32.0-33.0 \mathrm{~m}, 21.07 .1999$; WAM C 26020 (1 male, $2.9 \mathrm{~mm}$ ), stn DA2/99/73 $(6 \mathrm{~km} \mathrm{~S}$ of $\left.29^{\circ} 40.14^{\prime} \mathrm{S}, 116^{\circ} 27.69^{\prime} \mathrm{E}\right), 12.5 \mathrm{~m}, 24.07 .999$; WAM C 26024 (1 female, $1.8 \mathrm{~mm}$, with bopyrid), stn DA2/ $99 / 76\left(0.7 \mathrm{~km} \mathrm{~W}\right.$ of $\left.20^{\circ} 32.11^{\prime} \mathrm{S}, 116^{\circ} 31.55^{\prime} \mathrm{E}\right), 13.0-$ $15.0 \mathrm{~m}, 25.07 .1999 ;$ WAM C 27973 (1 female, 2.1 $\mathrm{mm})$, stn DA3/99/42 (20²9.34'S, $\left.116^{\circ} 36.80^{\prime} \mathrm{E}\right)$, intertidal, 28.08.1999; WAM C 27982, (1 male, 1.7 $\mathrm{mm} ; 2$ female, $1.6,1.8 \mathrm{~mm}$ ), stn DA3/99/48, Goodwyn I. $\left(20^{\circ} 32.00^{\prime} S, 116^{\circ} 32.42^{\prime} \mathrm{E}\right)$, intertidal, 30.08.1999; WAM C 27997 ( 2 males, 3.0, $3.3 \mathrm{~mm}$ ), stn DA3/99/56 (20 38.94'S, $\left.116^{\circ} 26.22^{\prime} \mathrm{E}\right), 2-11 \mathrm{~m}$, 03.10.1999; WAM C 28002 (1 male, $4.3 \mathrm{~mm}$ ), stn DA3/99/61 (20 34.66'S, $\left.116^{\circ} 39.72^{\prime} \mathrm{E}\right), 3.0-5.0 \mathrm{~m}$, 04.09.1999; WAM C 28009 (1 male, $2.8 \mathrm{~mm}$ ) and
WAM C 28011 (1 male, $4.3 \mathrm{~mm}$; 1 ovig. female, 3.3 $\mathrm{mm}$ ), station DA3/99/65 (20 37.10'S, 116 26.72'E), 13.0-15.0 m, 06.09.1999; WAM C 28018, (1 male, 3.6 $\mathrm{mm}$ ) and WAM C 28020 (1 male, $2.8 \mathrm{~mm}$ ), stn DA3/ $99 / 70\left(20^{\circ} 27.45^{\prime} \mathrm{S}, 116^{\circ} 39.58^{\prime} \mathrm{E}\right), 5.0-7.0 \mathrm{~m}$, 08.09.1999. Guam. FMNH (2 males, 1.6, $2.1 \mathrm{~mm} ; 5$ ovig. females, $1.3-1.7 \mathrm{~mm}$ ), Pago reef front, $4-8 \mathrm{~m}$, 14.08.2000.

\section{Abbreviated description}

Shield (Figure 27a) longer than broad; dorsal surface with tufts of long setae laterally. Branchiostegites each with row of spinules, at least in distal half and partially to completely concealed by long setae. Rostrum broadly triangular, usually reaching or slightly exceeding level of lateral projections, most frequently with terminal spinule. Ocular peduncles usually unequal with left somewhat longer; $0.5-0.9$ length of shield; corneal diameter $0.1-0.2$ of peduncular length; ocular acicles slender, simple, usually with prominent terminal spine. Antennular peduncles varying from reaching to bases of corneas to slightly overreaching distal corneal margins; second segment sometimes with small spine or spinule on ventral margin at midlength. Antennal peduncle reaching to distal 0.5-0.8 of ocular peduncles; fourth segment with small dorsodistal spine; third segment with ventrodistal margin produced, terminating in prominent spine; second segment with dorsolateral distal angle produced, terminating in simple or bifid spine, occasionally 1 additional spine on lateral margin; first segment with ventrolateral margin produced, unarmed. Antennal acicles reaching to distal half of fifth peduncular segment or beyond; each terminating in bifid spine, mesial margin with 1 or 2 spines, lateral margin usually also with 1 or 2 small spines; acicle and peduncular segments usually camouflaged in dense long setae. Antennal flagella much shorter than carapace, each article with several short setae.

Chelipeds (Figure 27b) subequal; similar in armament; dactyl and fixed finger with prominent hiatus. Dactyls each with row of moderately large, subacute spines on dorsomesial margin, dorsal surface with few tubercles or subacute spines; mesial face (Figure 27c) with irregular row of tubercles dorsally in proximal half few additional scattered tubercles distally, mesioventral margin with row of somewhat larger tubercles or subacute spines, at least partially concealed by tufts of long setae; cutting edge with row of small calcareous teeth in proximal 0.7 , corneous, usually fused, teeth distally. Palm with dorsal surface partially to entirely obscured by dense tufts of long setae; row of moderately large, sometimes corneous-tipped spines on dorsomesial margin, separated from remainder of dorsal surface by distinctly depressed area, scattered larger spines on dorsal surface and 


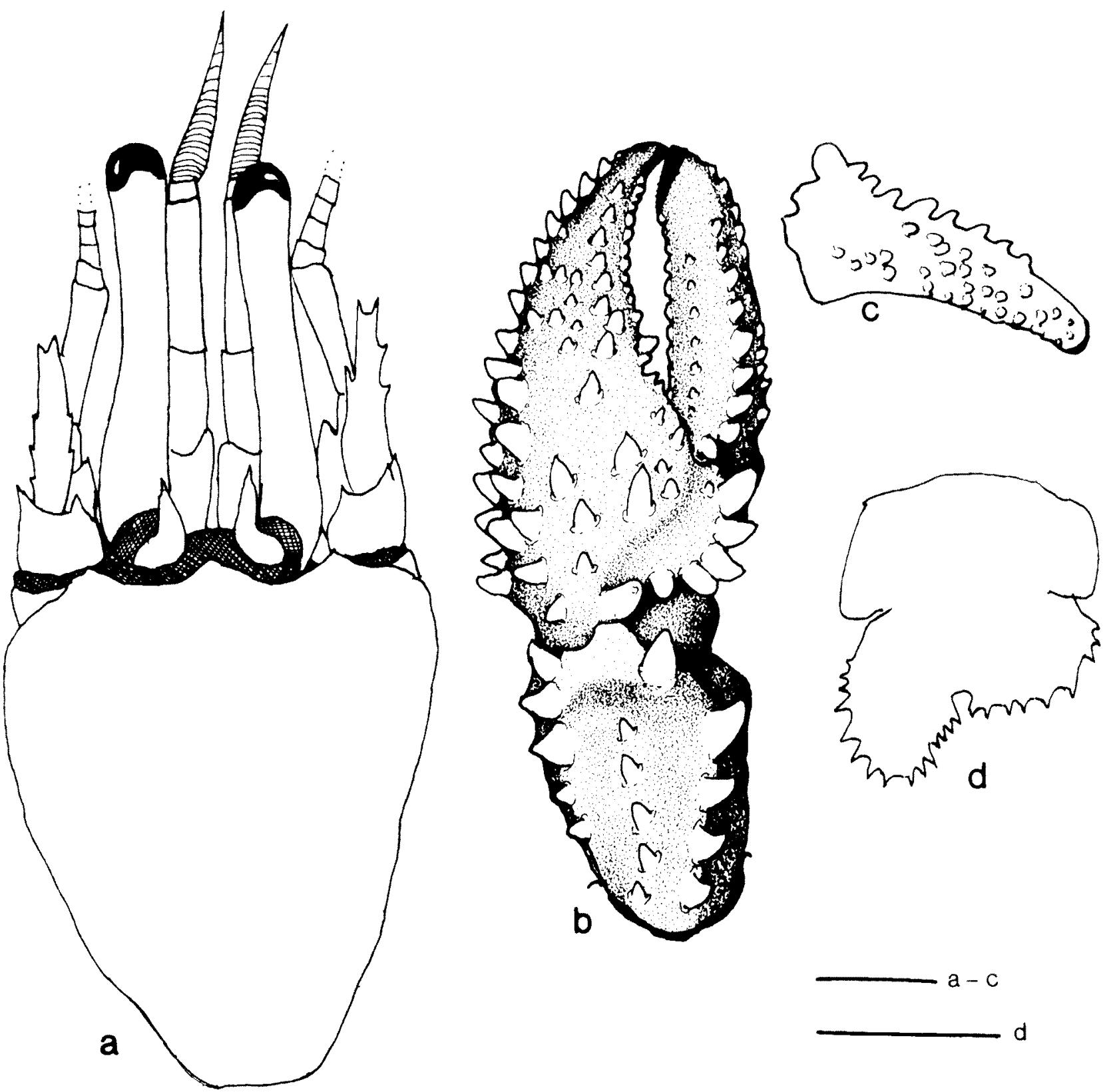

Figure 27 Pseudopaguristes monoporus (Morgan, 1987c), male (4.3 mm) (WAM C 28011). a, shield and cephalic appendages (aesthetascs and setae omitted); $b$, chela and carpus of left cheliped (dorsal view, setae omitted); c, dactyl of left chela (mesial view, setae omitted); delson (setae omitted). Scales equal $1 \mathrm{~mm}$.

fixed finger, dorsolateral margin with row of usually subacute spines extending nearly to tip of fixed finger; cutting edge with row of small calcareous teeth. Carpi each with row of 3 or 4 spines on dorsomesial margin, 1 large spine on angular dorsodistal margin laterally near articulation with propodus, distal marginal region prominently elevated, dorsal surface with row of moderately large spines in midline and second row at dorsolateral margin. Meri each with spinulose dorsal margin, at least in distal 0.3 ; ventromesial and ventrolateral margins each with row of small spines.

Second and third pereopods with dactyls slightly shorter to slightly longer than propodi; dorsal and ventral surfaces particularly with dense tufts of long setae, ventral margins each with row of 10-16 small corneous spines; propodi each with row of spines on dorsal margin concealed by tutts of long setae; carpi each with dorsal row of spines, largest on second pereopods, all at least partially obscured by tufts of long setae; meri also with marginal tufts of long setae; ventral margins each with row of small spines. Fourth pereopods each with small preungual process at base of claw.

Male usually with gonopore on right fifth coxa only; paired first pleopods with left reduced or 
absent; second left absent. Females with left gonopore only; brood pouch absent.

Telson (Figure 27d) with posterior lobes separated by medial cleft, left lobe largest. Lateral and posterior margins of both lobes with large spines.

\section{Colour}

"Shield cream or pale brown with darker brown mottling. Ocular peduncles white or cream with ventral, mesial, dorsal and lateral red-brown longitudinal stripes continuing onto cornea. Antennular peduncles with penultimate segment brown, ultimate segment distally bright blue; flagella orange. Antennal peduncles cream and pale brown; flagella banded in cream and brown. Chelipeds mottled cream and brown, finger tips cream. Pereopods 2 and 3 with merus and carpus cream mottled with red-brown and with thin longitudinal lateral red-brown stripe; propodus similar, but also with diffuse red-brown bands proximally and subdistally; dactyl similar to propodus but longitudinal lateral line sometimes obsolete. Occasionally a vague ventrolateral line on propodus and carpus. Pereopods 4 and 5 irregularly banded with cream and red-brown. Setae gray or pale brown, obscuring colors of chelipeds" (Morgan, 1987c).

\section{Habitat}

Coastal waters, associated with coral or soft sandy bottoms; intertidal to $33 \mathrm{~m}$.

\section{Distribution}

Queensland, Northern Territory and Dampier Archipelago, Australia; New Guinea; southeastern Indonesia; Phuket, Thailand; Cebu, Philippine Islands; Guam.

\section{Variation}

In his original description, Morgan (1987c) indicated that the ocular peduncles of Pseudopaguristes monoporus were long and slender, and his illustration (ibid. fig. 1a) of the holotype certainly supports that evaluation. However, like many species, the length of the ocular peduncle is influenced by animal size, with smaller specimens having shorter peduncles; however, as is also common among species, corneal diameter is inversely proportional, with corneal diameter decreasing as peduncular length increases. The specimens from Guam all were much smaller than their Australian counterparts, and their ocular peduncles were correspondingly shorter. The Guam specimens also were appreciably less setose, suggesting that perhaps setal density is also correlated with animal size. Additionally, the distinctive sculpturing seen on the dorsal surfaces of the palms and carpi of the chelipeds (Figure 27b) is not as prominent in the Guam specimens. Even in the Australian specimens the depressed area on the dorsal surface adjacent to the dorsomesial margin is not apparent unless the surface has been well denuded. It is undoubtedly for this reason that there was no mention made in the original description or has it been reported or illustrated by other authors.

Rahayu (2005) implied that although the species was characterized by the single right male gonopore, variation in the presence or absence of the left gonopore did occur. Among the nine males examined in the present study, only one had a small, incipient left gonopore.

\section{Remarks}

Despite the generally broad distribution of $P$. monoporus from Guam to Western Australia, prior to the examination of the Guam specimens, only one ovigerous female with a shield length of less than $2.0 \mathrm{~mm}$ had been recorded. The single ovigerous female in the type series had a shield length of $3.6 \mathrm{~mm}$. No shield length was given by Haig and Ball (1988) for their ovigerous female from Banda; however, Morgan (1990) listed six egg bearing females from Australia's Kimberley area with shield lengths from 2.0-3.1 mm. Rahayu (2005) reported two egg-bearing females with shield lengths of 1.8 and $1.5 \mathrm{~mm}$, from Indonesia. The five ovigerous females from Guam are, for the most part, even smaller, with shield lengths of only 1.3$1.7 \mathrm{~mm}$. Morgan's (1990) data seem to suggest that females mature at larger sizes in Australian waters.

\section{SUMMARY}

A total of 20 species of Paguristes s.s., one of Stratiotes and two of Pseudopaguristes are now recognized in the Australian fauna. Although, the genera Stratiotes and Pseudopaguristes are new to the region, the species representing them are familiar as members of Paguristes s.l. The same cannot be said for Paguristes s.s. Four new species have been added, as have five species reported previously from other regions: Paguristes miyakei and $P$. palythophilus were known only from Japanese waters until Rahayu (2006) recorded the latter's presence in Indonesia. The range of $P$. puniceus, inaccurately reported by Miyake (1978) to include Japan, now embraces the Indian Ocean, Indonesia and Australia. Because of the simultaneous discoveries of Paguristes alcocki and $P$. simplex in Australia and elsewhere in the IndoPacific, these species were initially published separately (McLaughlin and Rahayu, 2005; Rahayu and McLaughlin, 2006) and, therefore, are included as additions rather than new species in the Australian inventory. 
Not only have the results of the present investigation considerably increased species representation in Australian waters, the ranges of several species, heretofore thought to be very restricted, have been expanded substantially. For example, Paguristes kimberleyensis, known until now from only a single specimen collected in the Kimberley region of northern Western Australia, has been found to be moderately common in the Dampier Archipelago. Paguristes aciculus, described from two specimens collected off New South Wales, is now reported from as far west as the western portion of the Great Australian Bight in Western Australia and also has been recorded in Indonesia (Rahayu, 2006). Paguristes alegrias, known only from the Northern Territory and northwest Western Australia, has now also been found in the Dampier Archipelago. Similarly, the range of $P$. longisetosus has been extended eastward from the west and southwest coast of Western Australia to South Australia and Tasmania, while the distributions of $P$. brevirostris and $P$. sulcatus now include records from Victoria. Not only has the range of Pseudopaguristes laurentae been greatly expanded in Australian waters from Western Australia to South Australia, Tasmania, Victoria and New South Wales, this species is also recorded in Indonesia and Japan (Rahayu, 2005; Komai, 2001), albeit until now under different names.

\section{ACKNOWLEDGEMENTS}

The author is deeply indebted to the curators and collection managers of the museums cited, and in particular, Diana Jones and Melissa Titelius of the Western Australian Museum, for making this wealth of material available for study. Thanks are also due Dwi Listyo Rahayu, UPT Mataram, Indonesian Institute of Sciences (LIPI), Lombok, Indonesia, for sharing her prepublication information on the Indonesian species, to Tomoyuki Komai, Natural History Museum and Institute, Chiba, for providing comparative Japanese species, and to Karen Gowlett-Holmes, CSIRO Marine Laboratory, Hobart, Tasmania for providing specimens and photos of several species. This is a scientific contribution from the Shannon Point Marine Center, Western Washington University.

\section{REFERENCES}

Alcock, A. (1905). Anomura. Fasc. I. Pagurides. Catalogue of the Indian decapod Crustacea in the collections of the Indian Museum 2: 1-197. Indian Museum, Calcutta.

Alcock, A. and Anderson, A.R.S. (1897). Crustacea. In, Illustrations of the Zoology of the Roval Indian Marine Surveying Steamer Investigator. Part 5, pls 28-32. Calcutta.
Anderson, B.H. (1938). Decapoda. In: The Sir Joseph Banks Islands. Reports of the expedition of the McCoy Society for field investigation and research Proceedings of the Royal Soctety of Victoria, n.s. 50 $348-352$.

Asakura, A. and Kosuge, T. (2004). Pseudopaguristes bicolor, a new species of hermit crab (Crustacen Decapoda: Diogenidae) from Japan, the third species of the genus. Proceedings of the Biological Society of Washington 117: 57-67.

Asakura, A. and McLaughlin, P.A. (2003). A new species of Pseudopaguristes McLaughlin, 2002 (Crustacea: Decapoda: Diogenidae) from Japan. Procecdings of the Biological Society of Washington 116: $453-463$.

Baba, K. (1986). In K. Baba, Havashi, K-I and Torivama, M., Decapod crustaceans from continental shelf and slope around Japan. The Intensive research of unexploited fishery resources on continental slopes. Japan Fisheries Resource Conservation Association, Tokyo. $336 \mathrm{pp}$.

Baker, W.H. (1905). Notes on south Australian decapod Crustacea. Part III. Transactions of the Roval Society of South Australia 29: 252-269

Balss, H. (1912). Paguriden. In Chun, C. (ed.) Wissenschattliche Ergebnisse der deutschen TietseeExpedtion "Valdivia" 1898-1899. 20 (2): 85-124 Gustav Fischer, Jena.

Balss, H. (1913). Ostasiatische Decapoden 1. Die Galatheiden und Paguriden. In Beiträge zur Naturgeschichte Ostasiens, herausgegeben von Dr. F. Doflein. Abhandlungen der math.-phys. Klasse der K. Bayer. Akademie der Wissenschaften, Supplement $2(9): 1-85$.

Balss, H. (1924). Über Anpassungen und Symbiose der Paguriden eine Zusammenfassende Übersicht. Zeitschrift fü Morphologie und Ökologie der Tiere 1: $752-792$.

Balss, H. (1926-1927). Crustacea Malacostraca. Decapoda. In: Kuekenthal, W. and Krumbach, Th. (eds.), Handbuch der Zoologie 3 (1): 840-1038. Walter de Gruyter, Berlin and Leipzig.

Boas, J.E.V. (1880). Studier over decapodernes Slaegtskabsforhold. Kongelige Danske Videnskabernes Selskabs Skrifter. Naturvidenskabelig of Mathematisk Afdeling (5) 6 : 25-210.

Clark, E. and Burnet, F.M. (1942). The application of serological methods to the study of Crustacea. Australian Journal of Experimental Biology and Medical Science 20: 89-95.

Dana, J.D. (1851). Conspectus crustaceorum quae in orbis terrarum circumnavigatione, Carolo Wilkes e classe reipublicae foederatae duce, lexit ef descripsit. (Preprint from) Proceedings of the Academy of Natural Sciences, Philadelphia 5: 267-272.

Dana, J.D. (1852a). On the Classification of the Corystoidea, Paguridea, etc. 2. Conspectus crustaceorum, etc. Conspectus of the Crustacea of the Exploring Expedition under Capt. Wilks, U.S.N. (Preprint from) American foumal of Science and Arts (2) $23: 119-124$.

Dana, J.D. (1852b). Crustacea, part I. United States Exploring Expedition, during the vears 1838, 1839, 
1840, 1841, 1842, under the command of Charles Wilkes, U.S.N. 13: 1-685. C. Sherman, Philadelphia. Reprinted Antiquariaat Junk, Lochem, Netherlands, 1972.

Davie, P.J.F. (2002). Crustacea: Malacostraca: Eucarida (Part 2) Decapoda - Anomura, Brachyura. In: Wells, A. and Houston, W.W.K. (eds), Zoological Catalogue of Australia 19.3B. CSIRO Publishing, Melbourne, Australia. pp xiv $+641 \mathrm{pp}$.

Dechancé, M. (1963a). Sur des Paguristes littoraux de l'ouest de l'océan Indien: $P$. jousseaumei Bouvier, $P$. perspicax Nobili et $P$. abbreviatus sp. nov. (Crustacea Decapoda Paguridea). Bulletin du Muséum National d'Histoire Naturelle (2) 35: 291-301.

Dechancé, M. (1963b). Développement direct chez un Paguride, Paguristes abbreviatus Dechancé, et remarques sur le développement des Paguristes. Bulletin du Muséum National d'Histoire Naturelle (2) 35: 488-495.

Doflein, F. (1902). Ostasiatische Dekapoden. Abhandlungen der Königlichen. Bayerischen Akademie der Wissenschaften Math.-Phys. Klassen 21: 613-670.

Fabricius, J.C. (1775). Systema entomologiae, sistens insectorum classes, ordinies, genera, species, adiectis synonymis, locis, descriptionibus, observationibus. Officina Libraria Kortii, Flensburg and Leipzig. 832 pp.

Forest, J. (1954). Les Paguristes des côtes occidentales et méridionales d'Afrique. Annals of the South African Museum 41: 159-213.

Forest, J. and McLaughlin, P.A. (2000). Superfamily Coenobitoidea. In Forest, J., de Saint Laurent, M., McLaughlin, P.A. and Lemaitre, R. The marine fauna of New Zealand: Paguridea (Decapoda: Anomura) exclusive of the Lithodidae. NIWA Biodiversity Memoir 114: 31-103.

Forest, J. and de Saint Laurent, M. (1968). Résultats scientifiques des campagnes de la "Calypso", Part VII. Campagne de la Calypso au large des côtes Atlantiques de l'Amérique du Sud (1961-1962). 6. Crustacés Décapodes: Pagurides. Annales de I'Institut Océanographique de Monaco, n.s. 45 (2): 45-172.

Forest, J., de Saint Laurent, M., McLaughlin, P.A. and Lemaitre, R. (2000). The marine fauna of New Zealand: Paguridea (Decapoda: Anomura) exclusive of the Lithodidae. NIWA Biodiversity Memoir 114 $1-250$.

Gordan, J. (1956). A bibliography of pagurid crabs, exclusive of Alcock, 1905. Bulletin of the American Museum of Natural History 108: 253-352.

Grant, F.E. (1905). Crustacea dredged of Port Jackson in deep water. Proceedings of the Linnean Society of New South Wales 1905: 312-324.

Grant, F.E. and McCulloch, A.R. (1906). On a collection of Crustacea from the Port Curtis district, Queensland. Proceedings of the Linnean Society of New South Wales 1906: 1-53.

Griffin, D.J.G. (1967). Hermit crabs. Australian Natural History 15: 305-309.

Haig, J. (1956). Reports on the Lund University Chile Expedition 1948-1949. 20. The Crustacea Anomura of Chile. Lunds Universitet Arsskrift (2) 51 (12): 1-68.
Haig, J. and Ball, E.E. (1988). Hermit crabs from northern Australian and eastern Indonesian waters (Crustacea Decapoda: Anomura: Paguroidea) collected during the 1975 Alpha Helix Expedition. Records of the Australian Museum 40: 151-196.

Hale, H.M. (1927a). The crustaceans of South Australia. Part 1. Harrison Weir, Adelaide. 201 pp.

Hale, H.M. (1927b). The fauna of Kangaroo Island, South Australia. No. 1. The Crustacea. Transactions of the Royal Society of South Australia 51: 307-321.

Haswell, W.A. (1882). Catalogue of the Australian stalk and sessile-eyed Crustacea. The Australian Museum, Sydney. F.W. White, Sydney. 324 pp.

Heller, C. (1862). Neue Crustaceen, gesammelt während der Weltumseglung der k. k. Fregatte Novara. Zweiter vorläufiger Bericht. Verhandlungen der Kaiserlich-Königlichen Zoologisch-Botanischen Gesellschaft in Wien 12: 519-528.

Henderson, J.R. (1888). Report on the Anomura collected by H.M.S. Challenger during the years 1873-76. Scientific Results of the Exploratory Voyage of HMS Challenger, (Zoology) 27: 1-221. Her Majesty's Stationary Office, Edinburgh, etc.

Henderson. J.R. (1896). Natural history notes from H. M. 'Investigator' Commander C.F. Oldham, R.N., commanding.-Series II., No. 24. Report on the Paguridae collected during the season 1893-94. Journal of the Asiatic Society of Bengal 65: 516-536.

International Commission on Zoological Nomenclature. (1999). International Code of Zoological Nomenclature, $4^{\text {th }}$ edition. International Trust for Zoological Nomenclature, London. xxix +306 pp.

Jones, D.S. and Morgan, G.J. (1993). An annotated checklist of Crustacea from Rottnest Island, Western Australia. In Wells, F.E, Walker, D.I., Kirkman, H. and Lethbridge, R. (eds), Proceedings of the Fifth International Marine Biological Workshop: The Marine Flora and Fauna of Rottnest Island, Western Australia, Western Australian Museum, Perth 2: 135-162.

Jones, D.S. and Morgan, G.J. (1994). A field guide to crustaceans of Australian waters. Reed, Chatswood, NSW. 216 pp.

Jones, D.S. and Morgan, G.J. (2002). A field guide to crustaceans of Australian waters. $2^{\text {nd }}$ edition. Reed New Holland Publishers, Frenchs Forest, NSW. $223 \mathrm{pp}$.

Kemp, S. and Sewell, R.B. S. (1912). II. Notes on Decapoda in the Indian Museum. III. The species obtained by R.I.M.S.S. 'Investigator' during the survey season 1910-1911. Records of the Indian Museum 7: 15-32.

Kinahan, J.R. (1857). Remarks on Crustacea collected in Peru, the high seas, and South Australia; with descriptions of undescribed species. Journal of the Royal Dublin Society 1856/1857: 328-352.

Komai, T. (1999). Hermit crabs of the families Diogenidae and Paguridae (Crustacea: Decapoda: Anomura) collected during the Shin'yo-maru cruise to the Ogasawara Islands and Torishima Island, oceanic islands in Japan. Journal of natural History Museum and Institute, Chiba, Special issue 6: 1-66. 
Komai, T. (2001). A review of the north-western Pacific species of the genus Paguristes (Decapoda: Anomura: Diogenidae), I. Five species initially reported by Ortmann (1892) from Japan. Journal of Natural History 35: $357-428$.

Komai, T. (20(1)). Redescription of Pagurus conformis, the senior synonym of $P$. megalops (Crustacea: Decapoda: Anomura: Paguridat ${ }^{2}$. Species Diversits 9 : $343-358$.

Konishi, K. and Imafuku, M. $(2000)$. Hatchling of the symmetrical hermit crab Pomatocheles jeftrevis Miers, 1879: the first information on pylochelid larva (Anomura: Pylochelidae). Crustacean Research 29. $65-69$.

Kunze, J. and Anderson, D.T. (1979). Functional morphology of the mouthparts and gastric mill in the hermit crabs Clibanarius taeniatus (Milne Edwards), Clibanarius virescens (Krauss), Paguristes squamosus McCulloch and Dardanus setifer (Milne Edwards) (Anomura: Paguridae [sic]). Australian Journal of Marine and Freshwater Research 30: 683-722.

Lemaitre, R. (2004). Crustacea Decapoda: A worldwide review of the hermit crab species of the genus Sympagurus Smith, 1883. In Marshall B. and Richer de Forges, B. (eds), Tropical Deep-Sea Benthos, 23. Mémoires du Museum national d'Histoire naturelle 191: 85-149.

Lewinsohn, Ch. (1969). Die Anomuren des Roten Meeres (Crustacea Decapoda: Paguridea, Galatheidea, Hippidea). Zoologische Verhandelingen 104: 1-213.

Linnaeus, C. (1768). Systema naturae per regna tria naturae, secundum classes, ordines, genera, species, cum characteribus, differentiis, synonymis locis, (ed. 12) 1(2): 533-1327. Stockholm.

Lörenthey, E. and Beurlen, K. (1929). Die fossilen Dekapoden der Länder der ungarischen Krone. Mathematische und Naturwissenschattliche Berichte aus Ungarn 25 (3): 1-420.

Lucas, A.H.S. (1886). Note on the habits of hermit crabs. Transactions and Proceedings of the Royal Society of Victoria 22: 62.

McCulloch, A.R. (1913). Studies in Australian Crustacea. No. 3. Records of the Australian Museum 9: 321-353.

McLaughlin, P.A. (1974). The hermit crabs (Crustacea Decapoda, Paguridea) of northwestern North America. Zoologische Verhandelingen 130: 1-396.

McLaughlin, P.A. (2002a). Pseudopaguristes, a new and aberrant genus of hermit crabs (Anomura: Paguridea: Diogenidae). Micronesica 34: 185-199.

Mclaughlin, P.A. (2002b). A review of the hermit crab (Decapoda: Anomura: Paguridea) fauna of southern Thailand, with particular emphasis on the Andaman Sea, and descriptions of three new species. In Bruce, N., Berggman, M. and Bussarawit, S. (eds), Biodiversity of Crustacea in the Andaman Sea Proceedings of the Workshop held at the Phuket Marine Biological Center (PMBC), Phuket, Thailand, 29 November - 20 December, 1998. Phuket Marine Biological Center Research Bulletin, Special Publication 23: 384-460.

McLaughlin, P.A. (2003). Illustrated kevs to the families and genera of the superfamily Paguroidea (Crustacea:
Decapoda: Anomura), with diagnoses of the genera of Paguridae. In Lemaitre, R. and Tudge, C.C. (eds), Biology of the Anomura. Proceedings of a symposium at the Fifth International Crustacean Congress, Melbourne, Australia, 9-13 July 2001. Memoirs of Museum Victoria 60: 111-144.

Mclaughlin, P.A. (2004a). Redescription of Tomopaguroides valdiviae (Balss, 1911) (Decapoda: Anomura: Paguroidea: Paguridac) with notes on variation and female morphology. Zoosystema 26 : $455-468$.

Mclaughlin, P.A. (2004b). Paguristes puniceus Henderson, 1896 (Decapoda: Anomura: Paguroidea: Diogenidae): A study in intraspecific variability. Zootaxa 742: 1-28.

Mclaughlin, P.A. and Hogarth, P.J. (1998). Hermit crabs (Decapoda: Anomura: Paguridea) from the Seychelles. Zoologische Verhandelingen: 318: 1-48.

Mclaughlin, P.A. and Provenzano, A. J., Jr. (1974). Hermit crabs of the genus Paguristes (Crustacea: Decapoda: Diogenidae) from the western Atlantic. Part I. The Paguristes tortugae complex, with notes on variation. Bulletin of Marine Science 24: 165-234.

Mclaughlin, P.A. and Provenzano, A. J., Jr. (1975). Hermit crabs of the gemus Paguristes (Crustacea: Decapoda: Diogenidae) from the western Atlantic. Part II. Descriptions of six new species. Bulletin of Marine Science 24 (1974): 885-938.

Mclaughlin, P.A. and Rahayu, D.L. (2005). Two new species of Paguristes (Decapoda: Anomura: Paguroidea: Diogenidae). Zootaxa 1083: 31-62.

Mclaughlin, P.A. and de Saint Laurent, M. (1998). A new genus for four species of hermit crabs heretofore assigned to the genus Pagurus Fabricius (Decapoda: Anomura: Paguridae). Proceedings of the Biological Society of Washington 111: 158-187.

McLaughlin, P.A., Lemaitre, R. and Tudge, C.C. (2004). Carcinization in the Anomura - Fact or Fiction? Part II. Evidence from larval, megalopal and early juvenile morphology. Contributions to Zoology 73: 165-205.

Miers, E.J. (1879). On a collection of Crustacea made by Capt. H.C. St. John, R.N., in the Corean and Japanese Seas. Part I. Podophthalmia. With an appendix by Capt. II.C. St. Kohn. Procedings of the Zoologica. Society of London 1879: 18-61.

Milne-Edwards, A. (1880). Report on the results of dredging, under the supervision of Alexander Agassiz, in the Gult of Mexico, and in the Caribbean Sea, 1877, 78, 79, by the United States Coast Survey steamer "Blake", Lieut.-Commander C.D. Sigsbee, U.S.N., and Commander J.R. Bartlett, U.S.N., commanding. VIII. Etudes préliminaires sur les Crustaces. Bulletin of the Museum of Comparative Zoology, Harvard College 8(1): 1-68.

Milne-Edwards, A. and Bouvier, E.-L. (1893). Reports on the results of dredging, under the supervision of Alexander Agassiz, in the Gulf of Mexico (1877-78), in the Caribbean Sea (1878-79), and along the Atlantic coast of the United States (1880), by the U.S. Coast Survey Steamer "Blake", Liewt.-Commander C.D Sigsbee, U.S.N., and Commander J.R. Bartlett, U.S.N., commanding. XXXIII. Description des Crustacés de la famille des paguriens recueillis pendant l'expédition. 
Memoirs of the Museum of Comparative Zoology, Harvard College 14 (3): 5-172.

Milne Edwards, H. (1836). Observations zoologiques sur les Pagures et description d'un nouveau genre de la tribu des Paguriens. Annales des Sciences Naturelle Zoologie, Paris (2) 6: 257-288.

Milne Edwards, H. (1848). Note sur quelques nouvelles especes du genre Pagure. Annales des Sciences Naturelles Zoologie, Paris (3) 10: 59-64.

Miyake, S. (1961). Fauna and Flora of the sea around the Amakusa Marine Biological Laboratory. Part II. Decapod Crustacea. The Amakusa Marine Biological Laboratory, Kyushu University, Amakusa Kumamoto-ken, Japan. 30 pp.

Miyake, S. (1978). The crustacean Anomura of Sagami Bay. Pp 1-200 (English), Pp 1-161 (Japanese). Biological Laboratory, Imperial Household, Tokyo.

Miyake, S., 1982. Japanese crustacean decapods and stomatopods in color. Volume 1. Macrura, Anomura and Stomatopoda. Hoikkusa Publishing Co., Tokyo. 261 pp. Reprinted 1991, 1999.

Miyake, S. and Imafuku, M. (1980a). Hermit crabs from Kii Peninsula 1. Nankiseibutu: Nanki Biological Society 22: 1-7.

Miyake, S. and Imafuku, M. (1980b). Hermit crabs from Kii Peninsula II. Nankiseibutu: Nanki Biological Society 22: 59-64.

Miyake, S., Sakai K. and Nishikawa, S. (1962). A faunallist of the decapod Crustacea from the coasts washed by the Tsushima warm current. Records of Oceanographic Works in Japan Special Number 6: 121-131.

Morgan, G.J. (1987a). Hermit crabs (Decapoda, Anomura: Coenobitidae, Diogenidae, Paguridae) of Darwin and Port Essington, northern Australia. The Beagle, Records of the Northern Territory Museum of Arts and Sciences 4: 165-186.

Morgan, G.J. (1987b). Abbreviated development in Paguristes frontalis (Milne Edwards, 1836) (Anomura: Diogenidae) from southern Australia. Journal of Crustacean Biology 7: 536-540.

Morgan, G.J. (1987c). A new and aberrant species of Paguristes (Anomura: Diogenidae) from northern Australia. Records of the Western Australian Museum 13: 379-386.

Morgan, G.J. (1987d). Two new species of Paguristes (Decapoda: Anomura: Diogenidae) from southwestern Australia. Proceedings of the Biological Society of Washington 100: 726-734.

Morgan, G.J. (1989). The hermit crabs (Decapoda: Anomura: Diogenidae, Paguridae) of southwestern Australia, with descriptions of two new species. Records of the Western Australian Museum 14: 391417.

Morgan, G.J. (1990). A collection of Thalassinidea, Anomura and Brachyura (Crustacea: Decapoda) from the Kimberley Region of northwestern Australia. Zoologische Verhandelingen 265: 1-90.

Morgan, G.J. (1992). The hermit crabs (Crustacea: Decapoda: Coenobitidae, Diogenidae, Paguridae) of Christmas and Cocos (Keeling) Islands, Indian Ocean, with description of a new species of Paguristes. Raffles Bulletin of Zoology 40: 163-174.
Morgan, G.J. and Forest, J. (1991a). Seven new species of hermit crabs from northern and western Australia (Decapoda, Anomura, Diogenidae). Bulletin du Muséum national d'Histoire naturelle (4) A 12: 649 689.

Morgan, G.J. and Forest (1991b). Recognition of the Paguristes species, P. tomentosus (H. Milne Edwards, 1848 ) and $P$. sulcatus (Baker, 1905) (Decapoda, Anomura, Diogenidae). Crustaceana 60: 108-111.

Mower, A.G.J. and Shepherd, S.A. (1988). The crab fauna of West Island, South Australia: Their abundance, diet and role as predators of abalone. Transactions of the Royal Society of South Australia 112: 83-86.

Osawa, M. and Takeda, M. (2004). Hermit crabs (Crustacea: Decapoda: Paguroidea) from submarine caves in the Ryukyu Islands, south-western Japan. Journal of Natural History, 38: 1097-1132.

Ortmann, A. (1892). Die Decapoden-Krebse des Strassburger Museum. IV. Die Abtheilungen Galatheidea und Paguridea. Zoologisher Jahrbucher Systematik 6: 241-326.

Phillips, D.A.B., Handrech, C.P., Bock, P.E., Burn, R., Smith, B.J. and Stapels, D.A. (eds) (1984). Coastal invertebrates of Victoria. An atlas of selected species. Marine Research Group of Victoria and Museum of Victoria, Melbourne, $168 \mathrm{pp}$.

Pike, R.B. and Williamson, D.I. (1960). Larvae of decapod Crustacea of the families Diogenidae and Paguridae from the Bay of Naples. Pubblicazioni della Stazione Zoologica di Napoli 31: 493-552.

Pilgrim, R.L.C. (1973). Axial skeleton and musculature in the thorax of the hermit crab, Pagurus bernhardus [Anomura: Paguridae]. Journal of the Marine Biological Association United Kingdom 53: 363-396.

Porter, C.E. (1935). Catalogo de los paguridos de Chile. I. Generalidades y nociones biologicas. Revista Chilena de Historia Natural 39: 134-137.

Quintana, R. and Iwata, F. (1987). On the development of some hermit crabs from Hokkaido, Japan, reared under laboratory conditions (Decapoda: Anomura). Journal of the Faculty of Science, Hokkaido University, series 4 Zoology 25: 25-85.

Rahayu, D.L. (2000). Hermit crabs from the South China Sea (Crustacea: Decapoda: Anomura: Diogenidae, Paguridae, Parapaguridae). Raffles Bulletin of Zoology, Supplement 8: 377-404.

Rahayu, D.L. (2005). Indonesian new additions to the hermit crab genus Pseudopaguristes McLaughlin and a further division of the genus Paguristes Dana (Crustacea: Decapoda: Paguroidea: Diogenidae). Zootaxa 831: 1-42.

Rahayu, D.L. (2006). The genus Paguristes from Indonesia (Decapoda: Anomura: Diogenidae). In Richers de Forges, B. (ed.), Tropical Deep Sea Benthos, volume 24. Mémoires du Muséum national d'Histoire naturelle, 193: 349-374.

Rahayu, D.L. and Komai, T. (2000). Shallow-water hermit crabs (Crustacea: Decapoda: Anomura: Diogenidae and Paguridae) of Phuket, Thailand. Phuket Marine Biological Center Research Bulletin 63: 21-40.

Rahayu, D.L. and McLaughlin, P. (2006). Clarifications of the identities of Paguristes balanophilus Alcock and $P$. calvus Alcock (Decapoda: Anomura: Paguroidea: 
Diogenidae) and the description of another broadly distributed new species. Zoosystema 28: 865-886.

Rathbun, M.J. (1911). The stalk-eyed Crustacea of Peru and the adjacent coast. Proceedings of the United States National Muse'um 38: 531-620.

Rice, A.L. and Provenzano, A.J. Ir., (1965). The zoeal stages and the glaucothoe of Paguristes sericeus A. Milne-Edwards (Anomura, Diogenidae). Crustaceana 8: 239-254.

Saint Laurent-Dechancé, M., de (1966). Remarques sur la classification de la famille des Paguridae et sur la position systématique d'Iridopagurus de Saint Laurent-Dechancé. Diagnose d'Anapagrides gen. nov. Bulletin du Muséum National d'Histoire Naturelle (2) 38: 257-265.

Schmitt, W.L. (1933). Four new species of decapod crustaceans from Porto Rico. American Museum Novitates 662: 1-9.

Schram, F.R. and Koenemann, S. (2004). Developmental genetics and arthropod evolution: on body regions in Crustacea. pp. 75-92. In Scholtz, G. (ed.), Evolutionary developmental biology of Crustacea. Crustacean Issues 15. A.A. Balkema Publishers, Lisse, Abingdon, Exton (PA), Tokyo.

Stead, D.G. (1898). Habits of some Australian malacostracan Crustacea. [Australian] Zoologist, (4) 2: 208 .

Stimpson, W. (1858). Prodromus descriptionis animalium evertebratorum, quae in expeditione ad oceanum Pacificum septentrionalem, a Republica Federate missa, Cadwaldaro Ringgold et Johanne Rodgers ducibus, obseravit et descripsit. VII. [Preprint from] Proceedings of the Academy of Natural Sciences of Philadelphia 1858 [1859]: 225-252.

Stimpson, W. (1907). Report on the Crustacea (Brachyura and Anomura) collected by the North Pacific Exploring Expedition, 1853-1856. Smithsonian Miscellaneous Collections 49: 1-240.
Takeda, M. (1982). Kevs to the lapanese and foreign crustaceans fully illustrated in colour. Hokuryu-kan, Tokyo. 285 pp.

Terao, A. (1913). A catalogue of hermit-crabs found in Japan (Paguridea excluding Lithodidae), with descriptions of four new species. Annotationes Zoologicae Japonenses 8: 355-391

Thomson, G.M. (1899). A revision of the Crustacea Anomura of New Zealand. Transactions of the New Zealand Institute, Zoology 31: 169-197.

Tudge, C.C. (1995). Hermit crabs of the Great Barrier Re'ef and coastal Queensland. Backhuys Publishers, Leiden, $40 \mathrm{pp}$.

Wang, F. (1992). Studies on the hermit crabs fauna of China (Crustacea, Anomura). Donghai Marine Science 10: 59-63.

Wang, F.-Z. (1994). Anomura. Pp. 568 576. In Huang, Z.G., (ed.), Marine Species and Their Distributions in China's Seas. China Ocean Press, Beijing.

Wang, F.-Z. and Tung, Y.-M. (1982). New subspecies and new records of hermit crabs (Crustacea, Anomura) from China. Acta Zootaxonomica Sinica 7: 368-371.

Whitelegge, T. (1889). List of the marine and freshwater invertebrate fauna of Port Jackson and the neighbourhood. Journal and Proceedings of the Royal Society of New South Wales 23: 163-323.

Whitelegge, T. (1900). Scientific results of the trawling expedition of HMS Thetis, off the coast of New South Wales, February and March, 1898. Australian Mustum Memoirs 4: 135-199.

Yokoya, Y. (1933). On the distribution of decapod Crustacea inhabiting the continental shelf around Japan, chiefly based upon the materials collected by S.S. Soyo Maru during the years 1923-1930. Journal of the College of Agriculture Tokyo Imperial University 12: 1-236.

Yu, H.P. and Foo, K.Y. (1991). Hermit crabs of Taiwan S.C. Publishing Inc., Taipei. 78 pp.

Zariquiey Alvarez, R. (1968). Crustáceos Decápodos Ibéicos. Investigación Pesquera 32: 1-510. 